

$$
\text { ฮ }
$$






IN AUDUBON'S LABRADOR 




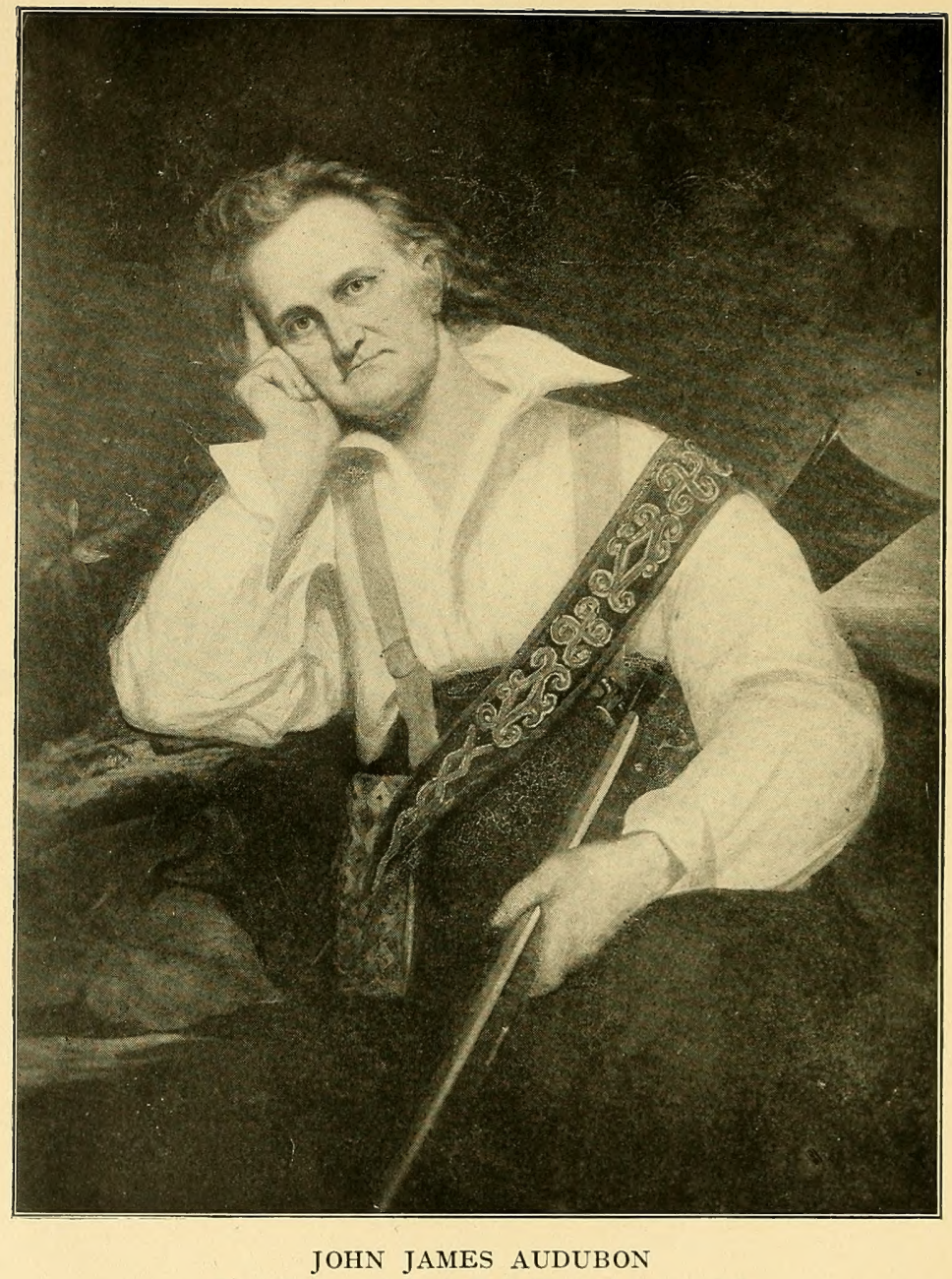

From the portrait by G. P. A. Healy, London, I 838 


\section{IN \\ AUDUBON'S LABRADOR}

BY

CHARLES WENDELL TOWNSEND, M.D.

AUTHOR OF

"Along the Labrador Coast," "A Labrador Spring"

"Captain Cartwright and bis Labrador Journal" and "Sand Dunes and Salt Marsbes"

\section{WITH ILLUSTRATIONS}

AND A MAP

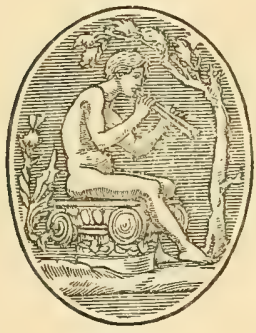

BOSTON AND NEW YORK HOUGHTON MIFFLIN COMPANY

cite thituerifide prege, Cambrioge I9 18 
COPYRIGHT, I9I8, BY CHARLES W, TOWNSEND

ALL RIGHTS RESERVED

Published April rors

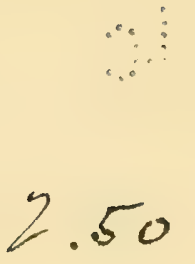

MAY -11918

(C) $C .1+585 \%$ 


\section{PREFACE}

IT is always a satisfaction to accomplish something one has dreamed about for years. Ever since my boyhood, when I read Audubon's Birds of America, with its frequent references to the Labrador coast, I have longed to follow the great ornithologist's footsteps in those regions. In I906, on a visit to eastern Labrador, I had a glimpse of Bradore and Blanc Sablon, the termination of Audubon's trip, and in I909 and I9I2 I reached from the West the starting-point of his trip at Natashquan and looked eagerly into the promised land. Only after another interval of three years was I able to carry out my long-cherished plan and explore the intervening two hundred and fifty miles - Audubon's Labrador.

I am indebted to many friends on the Labrador coast who are mentioned in these pages. I wish to thank Mr. Ruthven Deane, of Chicago, for the pictures of Thomas Lincoln and Joseph A. Coolidge and for his interest in this 


\section{PREFACE}

work; also Dr. Frederick C. Shattuck for the photograph of his father and for the letters published in the Appendix.

The portion of Chapter XII concerning the old stumps at Blanc Sablon has been published in Rhodora for September, I9I6, and a part of Chapter XIII has been published in the Seventh Annual Report of the Commission of Conservation, Canada, I9I6. Chapter XIV was published in The $A u k$, for I9I4.

In the Index will be found the scientific names of the plants and animals referred to in the text.

Boston, February, IgI8. 


\section{CONTENTS}

I. Audubon's Labrador Trip . . . . . I

II. To the Starting-Point • • • . . . 27

III. American Harbor, or Natashquan • • 46

IV. Grand Romaine and Old Romaine • 74

V. Wapitagun • • • • • • • • • IIo

VI. As far as Dr. Grenfell's Hospital at HaR-

RINGTON • • • • • • • • • I27

VII. Little Mecattina Island and Mutton Bay I53

ViII. Through the Petite Rigolet to the St.

Augustine River • • • • • . 166

IX. Shecatica and Jacques Cartier . • . I82

X. A Descendant of the Chevalier de St. Paul; With Remarks on Vinland the Good ANd the Port of Brest . . 208

XI. Bradore Bay and Perroquet Island . 230

XII. Blanc Sablon • • • • • • • 244

XIII. Conservation in LabradoR • • • 272

XIV. A Plea for the Conservation of the Eider 301

Appendix • . • • • • • • • •

Index • • • • • • • • • • 339

vii 



\section{ILLUSTRATIONS}

John James Audubon . . . . . Frontispiece

From the portrait by G. P. A. Healy, 1838 , in the possession of the Boston Society of Natural History

George C. Shattuck, William Ingalls, John

Woodhouse Audubon, And Joseph A. Coolidge . 4

Thomas Lincoln . . . . . . . . . I2

Lincoln's Sparrow: Audubon Plate . . . 12

Captain J. Hearn • • • • • • • 28

Napoleon A. Comeau . . . . . . . . 28

The Priests of Natashquan . . . . . 36

M. Johan Beetz . • • • . . . . . 36

Falls of Grand River of Piashte Bay • • . 42

Nest of Red-breasted Merganser: Labrador-

TEA • . . . . . . . . . . . 42

American Harbor, or Natashquan . . . 46

Eider Ducks: Audubon Plate . . . . . 46

Montagnais Indian Girls picking Mountain

Cranberries (Graines Rouges) at Natashquan . 54

Indian Couple at Romaine . . . . . 54

The Sea Star . . . . . . . . 76 


\section{ILLUSTRATIONS}

Captain A. Edmond Joncas • . . • . 76

Looking North over Grand Romaine River NEAR ITS MOUTH . . . . . . . . 86

INDIANS AT ROMAINE . • • • • . . 86

Surf on Harbor Island, Old Romaine • • 94

Hauling a Cod-Trap . . . . . . . 94

Great Blact-backed Gulls . . . . . 98 Photograph by Howard H. Cleaves

Young Great Black-Backed Gulls • • • 98

Outer Island: Murres AND their Eggs: DoubleCrested Cormorants, Nests, and Young . . II2

Cape Whittle • • • • • • • • . II8

Nest of Double-Crested Cormorant containING YOUNG . . . • . . . . . . III8

Wapitagun: Nesting-Pool of Red-throated Loon 124 Red-throated Loon: Audubon Plate • . . I24

The Captain and William putting up the Cross at Matchiatik Island . . . . . I28

Nest of Ring-billed Gull with Eggs and YOUNG • . . . . . . . . . . 128

Cleaning Fish at Seal-Net Point, or Pointe au Maurier . . . . . . . . . . 132

Near the Summit of Little Mecattina: Poised BOULDERS . . . . . . . . . . I32 HARRington ANd the Hospital . . . . . 146 


\section{ILLUSTRATIONS}

Our Friends the Eskimo Puppies and their Mother at Harrington . . . . . . 146

The Sea Star in Hare Harbor, Little MecatTINA ISLAND . . . . . . . . • . 158

Mutton Bay (Baie de Portage) . . . . . I68

Samuel Robertson, 3D, AND some of his Dogs, at Sparr Point . . . . . . . . . . I68 Petite Rigolet • • • • • . • • . 174

The Cook and the First Mate of the Sea Star 174

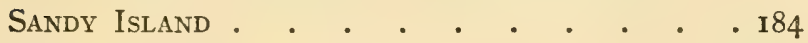
Cumberland Head . . . . . . . . . I84 Strand Wheat • . . . . . . . . . I 88

Glacial Lunoid Furrows and Grooves . . 188

The Sea Star in Shecatica Inlet • • • . 194

Shecatica River • . • • • . • • . 194

Looking down Shecatica Inlet from the Grand Portage . . • • • . . . . . . . 198

Framework of Sweat-House at Indian Camping-Place on the Grand Portage . . . 198 Entering Shecatica Inlet • . . . . 204 Spruce Grouse . . . . . . . . . . 204 Grassy Island: RAISED BeAch • • • • . 222 Old Fort: Site of Brest . • . • . . . 222 Showing Raised Beaches

A Glimpse of Bradore in the Fog . . . . 240 $\mathrm{xi}$ 


\section{ILLUSTRATIONS}

Perroquet Island

Cow Parsnips and Strand Wheat at Perroquet

ISLAND • • . • . . . . • • . 244

Blanc Sablon: Job Brothers and Company,

Limited . • • • . . . . . . . 244

The Cliffs at Blanc Sablon . . . . .248

The Valley at Blanc Sablon • . . . . 248 Photograph by Edmund Hunt

A Descendant of the Chevalier de St. Paul . 268

Davy, a Big Cod, and Mr. Grant • . . . 268 Photograph by Edmund Hunt

Double-CRESTED CORMORANTS LEAVING THEIR Nests at Gull Island off Cape Whittle . 290

Double-Crested Cormorants and Murres . . 290

Facsimile of a LetTer from Audubon to Dr. George C. Shattuck . . . . . . . 334

Map of Audubon's Labrador • • . . 338 
IN AUDUBON'S LABRADOR 



\section{IN AUDUBON'S LABRADOR}

\section{CHAPTER I}

AUDUBON'S LABRADOR TRIP

WOR many years John James Audubon, the I great ornithologist, had contemplated a trip to Labrador in order to study and paint the birds of that coast for his monumental work "The Birds of America." On the 6th of June, I833, he sailed from Eastport, Maine, in the schooner Ripley, of one hundred and six tons burden, commanded by Captain Emery. His party consisted of five young and vigorous men, all between eighteen and twenty-one years of age, who were looking forward to all the pleasures, hardships, and adventures of the trip, and to doing loyal work for their leader in procuring specimens of birds and eggs as well as other objects of natural history. Of these, George C. Shattuck, of Boston, was afterwards a well-known physician, under whom many years later it was my privilege to serve as house officer at the Massachu- 


\section{IN AUDUBON'S LABRADOR}

setts General Hospital. He was the son of Dr. George Cheyne Shattuck, and he died in 1893 in his eightieth year. His two sons, Frederick C. and George B., and his grandson, George C., are all well-known physicians in Boston to-day. Another was William Ingalls, of Boston, who afterwards became a physician. $\mathrm{He}$ was a charming man and one who carried the bloom and optimism of youth until his death within a month of his ninety-first birthday in 1903. A motto he once sent me with a pair of sugar tongs is characteristic of the man: "Something to pick up sweets with as onward you journey along." Joseph A. Coolidge, of Maine, the third of this band, died in California in I90I at the age of eighty-six. The fourth was Thomas Lincoln, of Dennysville, Maine, the son of an old friend of Audubon and one whose name ornithologists all remember, as it was immortalized by Audubon in the name of a new species of sparrow discovered in Labrador. He died at the age of seventyone on his birthday, March 27, in I883. There remains Audubon's son, John Woodhouse Audubon, the artist, who, of this band of young men, was the only one to fail to reach advanced age, for he died in his fortieth year, in 1862 . He was 


\section{AUDUBON'S LABRADOR TRIP}

the father of Miss Maria R. Audubon, who has preserved for all time her father's history in that interesting work "Audubon and his Journals."

A letter written October 9, I896, to Miss Audubon by Mr. Joseph Coolidge says of the great leader: "You had only to meet him to love him; and when you had conversed with him for a moment, you looked upon him as an old friend, rather than a stranger. ... To this day I can see him, a magnificent gray-haired man, childlike in his simplicity, kind-hearted, noble-souled, lover of nature and lover of youth, friend of humanity, and one whose religion was the golden rule." 1

Dr. William Ingalls, ${ }^{2}$ in a letter to Mr. Ruthven Deane, dated October 30, 1902, gives an interesting outline of his recollection of the individuals of the party as follows:-

"Mr. Audubon was known by many, and I think there is no exception to the fact that those that have spoken of him have testified to his great amiability and manliness, his humanity, and it has always seemed to me he was one of

1 A udubon and his Journals, vol. I, p. 68.

2 The Auk, vol. xxvir (I9Io), p. 47. 


\section{IN AUDUBON'S LABRADOR}

those men who, on meeting, one would at once say, 'Bless you, dear man.'

"Tom Lincoln, quiet, reserved, sensible, practical and reliable. George C. Shattuck, a quiet man, but if you had thought him a goose you would soon have discovered your mistake. Joe Coolidge, unselfish, with a lot of sea and other practical knowledge, and a right good fellow. John W. Audubon, always good-natured, he and his papa the best of (boyish) friends, cheering us sometimes with his violin. I have spoken of the Captain whom we all honored for his skill and his evident desire to help the expedition, and now let me repeat a truth which was uttered by Mr. Audubon: 'Brought together, strangers, three months in a small ship, we can say there was not a word or spirit of an unpleasant nature in all that time." "

Mr. Ruthven Deane tells me that Captain Emery died of yellow fever in 1840 , and that the schooner Ripley met her fate a few years later when she was wrecked in the Bay of Chaleurs.

In a letter, ${ }^{1}$ written to his son Victor on the eve of his departure, Audubon says: "We are

1 This and the following quotations in this chapter are from "The Labrador Journal" in Audubon and his Journals, referred to above. 




GEORGE C. SHATTUCK

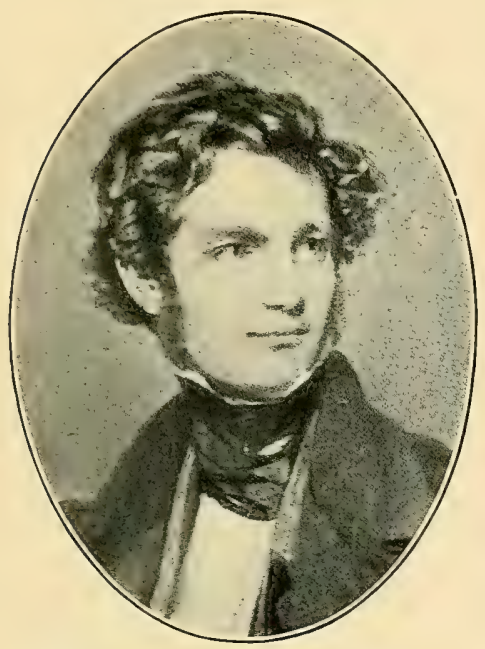

JOHN WOODHOUSE AUDUBON

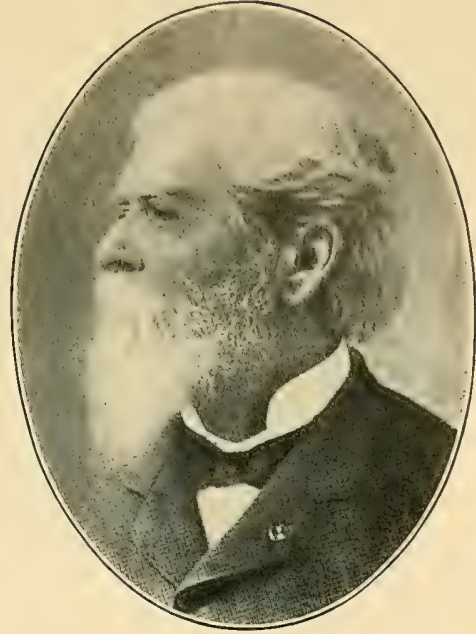

WILLIAM INGALLS

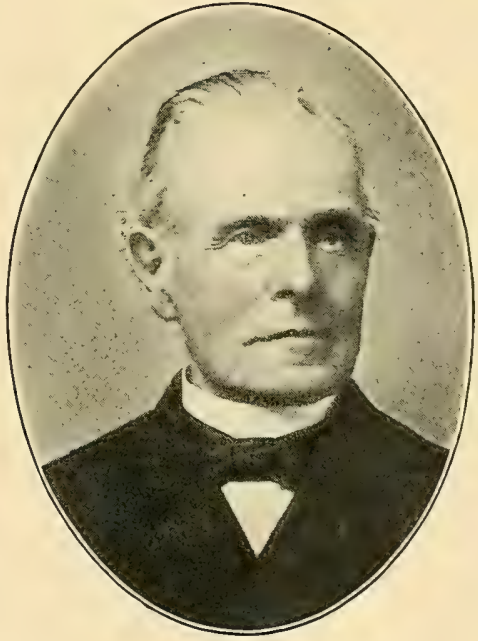

JOSEPH A. COOLIDGE 

well provided as to clothes, and strange figures, indeed, do we cut in our dresses, I promise you: fishermen's boots, the soles of which are all nailed to enable us to keep our footing on the sea-weeds, trousers of fearnought so coarse that our legs look like bears' legs, oiled jackets and over-trousers for rainy weather, and round, white, wool hats with a piece of oil cloth dangling on our shoulders to prevent the rain from running down our necks. A coarse bag is strapped on the back to carry provisions on inland journeys, with our guns and hunting-knives; you can form an idea of us from this."

At last they were off on June 6, I833, amid the cheers of the whole "male population" of Eastport, and the booming of cannon from the batteries on shore and a revenue cutter in the harbor. Three days later they were "all shockingly sea-sick, crossing that worst of all dreadful bays, the Bay of Fundy." They came to anchor amid a fleet of fishermen in the harbor of Canso, and had a brief run ashore, and later touched at Jestico Island off the western coast of Cape Breton. On July 13 they landed at the Magdalen Islands and with the thermometer at $44^{\circ}$ "we blew our fingers and drank our coffee, feeling as if in the 


\section{IN AUDUBON'S LABRADOR}

very heart of winter." As Audubon was following a tortuous path, he suddenly "came plump upon one of God's best finished jewels, a woman. She saw us first, for women are always keenest in sight and sympathy, in perseverance and patience, in fortitude, and love, and sorrow, and faith, and, for aught I know, much more. At the instant that my eyes espied her, she was in full run towards her cottage, holding to her bosom a fine babe, simply covered with a very short skirt, the very appearance of which set me shivering. The woman was dressed in coarse French homespun, a close white cotton cap, which entirely surrounded her face, tied under her chin, and I thought her the wildest-looking woman, both in form and face, I had seen for many a day. At a venture, I addressed her in French, and it answered well, for she responded in a wonderful jargon, about one third of which I understood, and abandoned the rest to a better linguist, should one ever come to the island."

The next day they set sail for what Mr. Godwin, their pilot, "called 'The Bird Rocks,' where he told us that Gannets (Sula bassana) bred in great numbers." At eleven o'clock Audubon saw the rock plainly, "and thought it covered with 


\section{AUDUBON'S LABRADOR TRIP}

snow to the depth of several feet; this appearance existed on every portion of the flat, projecting shelves. Godwin said, with the coolness of a man who had visited this Rock for ten successive seasons, that what we saw was not snow - but Gannets! I rubbed my eyes, took my spy-glass, and in an instant the strangest picture stood before me. They were birds we saw, - a mass of birds of such a size as I never before cast my eyes on. . . . No man who has not seen what we have this day can form the least idea of the impression the sight made on our minds." It was too rough to land, and they sailed on, all except Coolidge "deadly sick," but Audubon looked forward with eagerness to the landing on the coast of Labrador. "My thoughts were filled, not with airy castles, but with expectations of the new knowledge of birds and quadrupeds which I hoped to acquire."

At five o'clock on June I7, I833, "the cry of land rang in our ears, and my heart bounded with joy; so much for anticipation.... The shores appeared to be margined with a broad and handsome sand-beach; our imaginations now saw Bears, Wolves, and Devils of all sorts scampering away on the rugged shore." They 


\section{IN AUDUBON'S LABRADOR}

came to anchor in what was then called American Harbor, now Natashquan, at the mouth of the Little Natashquan River some five miles to the westward of the mouth of the Great Natashquan River. "And now we are positively on the Labrador coast, latitude $50^{\circ}$ and a little more, farther north than I ever was before. But what a country! When we landed and passed the beach, we sank nearly up to our knees in mosses of various sorts, producing as we moved through them a curious sensation. These mosses, which at a distance look like hard rocks, are, under foot, like a velvet cushion. We scrambled about, and with anxiety stretched our necks and looked over the country far and near, but not a square foot of earth could we see. A poor, rugged, miserable country; the trees like so many mops of wiry composition, and where the soil is not rocky it is boggy up to a man's waist."

They remained at American Harbor until June 28 , and employed the time well in studying the land-and sea-birds of the vicinity; for the last five days storm and head winds prevented their attempts to depart. Audubon speaks of "millions" of velvet ducks - white- 


\section{AUDUBON'S LABRADOR TRIP}

winged scoters - flying from the northwest to the southeast, and of the immense numbers of eiders, murres, and razor-billed auks. He is impressed with the extremely shy and wary character of the waterfowl, "which to me in this wonderfully wild country is surprising." On one occasion he walked four miles up the shore of the Little Natashquan River as far as the falls, but most of the time he spent at his drawing-table, leaving the work of procuring specimens to the younger members of his party. He begins his day at two o'clock, "for we have scarcely any darkness now," and at his work he is able to hear some bird songs. He says "so sonorous is the song of the Foxcolored Sparrow that I can hear it for hours, most distinctly, from the cabin where I am drawing, and yet it is distant more than a quarter of a mile." In another place he says: "The Turdus migratorius [Robin] must be the hardiest of the whole genus. I hear it at this moment, eight o'clock at night, singing most joyously its 'Good-night' and 'All's well!' to the equally hardy Labradorians."

Audubon was astonished at the rapidity of development of the arctic spring on these 


\section{IN AUDUBON'S LABRADOR}

shores. He notes on June $2 \mathrm{I}$ : "I found many small flowers open this day, where none appeared last evening. All vegetable life here is of the pygmy order, and so ephemeral that it shoots out of the tangled mass of ages, blooms, fructifies, and dies, in a few weeks."

He came in contact with the nefarious trade of the "egger." "We ascertained to-day that a party of four men from Halifax took last spring nearly forty thousand eggs, which they sold at Halifax and other towns at twentyfive cents per dozen, making over $\$ 800$; this was done in about two months. Last year upward of twenty sail were engaged in 'egging'; so some idea may be formed of the birds that are destroyed in this rascally way."

On June 22, Audubon visited the little settlement at the mouth of the Great Natashquan River, the establishment of the Hudson's Bay Company, and described the Montagnais Indians there. He says: "So shy of strangers are the agents of the Fur and Fish Company that they will evade all questions respecting the interior of the country, and indeed will willingly tell you such untruths as at once disgust and shock you. All this through the 


\section{AUDUBON'S LABRADOR TRIP}

fear that strangers should attempt to settle here, and divide with them the profits which they enjoy."

On the same day the vessel Gulnare, Captain Bayfield, entered the harbor on a surveying cruise. He found the ship's doctor to be a student of botany and conchology. "Thus men of the same tastes meet everywhere, yet surely I did not expect to meet a naturalist on the Labrador coast." Later he dined on the Gulnare at five o'clock, "and was obliged to shave and dress - quite a bore on the coast of Labrador, believe me." The party consisted of the captain, the surgeon, and three officers, and "the conversation ranged from botany to politics, from the Established Church of England to the hatching of eggs by steam. I saw the maps being made of this coast, and was struck with the great accuracy of the shape of our present harbor, which I now know full well."

On June 27 he records the discovery of a new species of bird, the Lincoln's sparrow: "We shot a new species of Finch, which I have named Fringilla lincolnii." On July 4 he says: "I have drawn all day, and have finished the 


\section{IN AUDUBON'S LABRADOR}

plate of the Fringilla lincolnii, to which I have put three plants of the country, all new to me and probably never before figured; to us they are very fitting for the purpose, as Lincoln gathered them." These plants are the pale laurel, the northern dwarf cornel, and the cloudberry, or bake-apple as it is called by the English-speaking people of Labrador, Newfoundland, and Cape Breton. Chicoutai is its Indian name and it is so called by the Acadians along the southern coast of the Labrador Peninsula. It is circumpolar in its distribution and is found in the northern parts of the Old World as well as in the New. It belongs to the raspberry family and resembles a large berry of that group; it is red when nearly ripe, but turns yellow when it is ready to eat. It is much esteemed by the natives, but its flavor, to one unaccustomed to it, is not attractive. It makes, however, an excellent preserve, although somewhat seedy withal. In the spring its two or three large leaves and single white flower are conspicuous in the moss, and in the summer its handsome fruit is very prominent.

On the afternoon of June 28 , following a 



\section{AUDUBON'S LABRADOR TRIP}

week's delay due to easterly winds with rain and fog, a favorable westerly breeze sprang up, the explorers set sail, and the next morning found themselves near islands on which murres, puffins, razor-billed auks, and cormorants were breeding by thousands. These islands are stated to be about fifty miles from Natashquan and were probably in the neighborhood of Old Romaine. From there the Ripley continued down the coast, and toward the end of the day came to anchor in the harbor of Wapitagun. Audubon says, "but as before our would-be pilot could not recognize the land," and they found difficulty in entering the harbor "on account of our pilot being an ignorant ass; twice did we see rocks under our vessel. The appearance of the country around is quite different from that near American Harbor; nothing in view here, as far as the eye can reach, but bare, high, rugged rocks, grand, indeed, but not a shrub a foot above the ground. The moss is shorter and more compact, the flowers are fewer, and every plant more diminutive. No matter which way you glance, the prospect is cold and forbidding; deep banks of snow appear here and there, 


\section{IN AUDUBON'S LABRADOR}

and yet I have found the Shore Lark (Alauda alpestris) in beautiful summer plumage." $\mathrm{He}$ is continually complaining of the cold - "The weather was so cold that it was painful for me to draw almost the whole day" - and of the wet and storm and of the desolate character of the country, yet he thoroughly enjoyed it when the sun came forth and warmed his Southern blood. This is shown by the entry in his Journal for July 2. "A beautiful day for Labrador. ... All - all is wonderfully grand, wild - aye, and terrific. And yet how beautiful it is now, when one sees the wild bee; moving from one flower to another in search of food, which doubtless is as sweet to it as the essence of the magnolia is to those of favored Louisiana."

The next day, however, "We had a regular stiff gale from the eastward the whole day, accompanied with rain and cold weather, and the water so rough that I could not go ashore to get plants to draw." His hands were full of work in this place, as water- and land-birds abounded and he was delighted at procuring some ptarmigan and young. On July 6 he says: "By dint of hard work and rising at 
three, I have drawn a Colymbus septentrionalis [red-throated loon] and a young one, and nearly finished a Ptarmigan; this afternoon, however, at half-past five, my fingers could no longer hold my pencil, and I was forced to abandon my work, and go ashore for exercise. The fact is that I am growing old too fast; alas! I feel it - and yet work I will, and may God grant me life to see the last plate of my mammoth work finished." Later in the Journal, under date of August Io, he says: "I have been drawing so constantly, often seventeen hours a day, that the weariness of my body at night has been unprecedented, by such work at least. At times I felt as if my physical powers would abandon me; my neck, my shoulders, and, more than all, my fingers, were almost useless through actual fatigue at drawing. ... The young men think my fatigue is added to by the fact that I often work in wet clothes, but I have done that all my life with no ill effects. No! no! it is that I am no longer young."

Until the publication in I9r7 of the important work on "Audubon the Naturalist," by Francis Hobart Herrick, there was a mystery 


\section{IN AUDUBON'S LABRADOR}

about the date of Audubon's birth, which was generally recorded as occurring on May 5, I 780, with the extreme limits I772 and I783. Herrick, however, has shown by indisputable documentary evidence that the great naturalist was born at Les Cayes, Santo Domingo, on April 26, I785. He was, therefore, only fortyeight years of age at the time of the Labrador expedition. The cause of his exhaustion, however, was plainly his excessively long hours of sedentary work under difficult and depressing circumstances of cold, wet, and sea-sickness.

The mosquitoes also added to his difficulties, for no means were used to keep them out of the cabin. He says: "The mosquitoes trouble me so much that in driving them away I bespatter my paper with ink, as thou seest, God bless thee. Good-night." Again: "The mosquitoes so annoyed me last night that I did not even close my eyes." And in another place he says: "The Caribou flies have driven the hunters on board; Tom Lincoln, who is especially attacked by them, was actually covered with blood, and looked as if he had had a gouging fight with some rough Kentuckians." 


\section{AUDUBON'S LABRADOR TRIP}

Although stormy weather is common on this coast, Audubon was certainly unfortunate in experiencing an unusually stormy season. Of the fifty-four days between June 17 and August I I that were spent on the Labrador coast, he speaks of rain and fog and storm on at least twenty-five, and he had apparently only fifteen days of fine weather. His Southern blood rebelled against the Northern cold and storm.

Still another handicap was his "ignorant ass" of a pilot, who, not knowing the region, exposed them to no inconsiderable danger of shipwreck, on entering and leaving harbors, and who was obliged to sail for safety on the rough waters of the Gulf rather than in the calm and narrow waterways among the islands. It is probable that homesickness added to Audubon's troubles, as is shown by such records as, "John's violin notes carry my thoughts far, far from Labrador, I assure thee."

It is a curious fact that in the Journal Audubon never once mentions his food, ${ }^{1}$ an item that is often dwelt upon with a great deal of either favorable or unfavorable feeling by

1 In one of the "Episodes," however, he says they "were fortunate in having a capital cook, although he was a little too fond of the bottle." 


\section{IN AUDUBON'S LABRADOR}

most travelers. He says, however, that his young companions "have yet energy to eat tremendously." In a letter ${ }^{1}$ written to $\mathrm{Mr}$. Ruthven Deane by Dr. William Ingalls in his ninetieth year occurs the following: "And permit me to say cornmeal bread made by a good cook with sea-birds' eggs is fit for Yum-Yum!! Excuse me, I am nothing but a boy." This bears out my contention that the usual idea of the meaning of the phrase, "Whom the gods love die young," is incorrect. It really means that those whom the gods love die young even if they live to be a hundred.

On July I3, taking advantage of a favorable wind, the Ripley sailed again easterly on the open sea, and on the next day in rough water managed by good luck to enter the harbor of "Little Macatine," and all were soon ashore climbing the hills. This is Hare Harbor in the island of Little Mecattina. "Nothing but rocks - barren rocks - wild as the wildest of the Apennines everywhere." True naturalist that he was, everything interested him. The raised beaches of pebbles he attributed to the

1 The $A u k$, vol. xxvir (19ro), p. 48. 


\section{AUDUBON'S LABRADOR TRIP}

tremendous gales of the coast and to icebergs. "Plants blooming by millions, and at every step you tread on such as would be looked upon with pleasure in more temperate climes. I wish I were a better botanist that I might describe them as I do the birds." Again: "The captain brought me what he called an Esquimau codfish, which perhaps has never been described, and we have spirited him." His keenness of observation is well shown by the following: "This bird [a spruce partridge] was so very gray that she might almost have been pronounced a different species from those at Dennysville, Me., last autumn; but this difference is occasioned by its being born so much farther north; the difference is no greater than in Tetrao umbellus [ruffed grouse] in Maine, and the same bird in western Pennsylvania." Both of these observations have since been confirmed and two separate races of each bird have been recognized by ornithologists.

The country about this harbor was thoroughly searched for bird life. On July i 8 he says: "From the top of a high rock I had fine view of the most extensive and the dreariest wilderness I have ever beheld. It chilled the 


\section{IN AUDUBON'S LABRADOR}

heart to gaze on these barren lands of Labrador.... The mosquitoes, many species of horse-fly, small bees, and black gnats filled the air; the frogs croaked; and yet the thermometer was not high, not above $55^{\circ}$. This is one of the wonders of this extraordinary country." They found the deserted cabin of a sealer, and Audubon discovered that it "had been the abode of two French Canadians; first, because their almanac, written with chalk on one of the logs, was in French; and next, the writing was in two very different styles."

4. On July 2I they left Little Mecattina Island and in five hours reached "a harbor which has no name, for we have mistaken it for the right one, which lies two miles east of this; but it matters little, for the coast of Labrador is all alike comfortless, cold and foggy yet grand." This harbor, which he elsewhere speaks of as Baie de Portage, is now called Mutton Bay. Here he found Captain Bayfield, of the Gulnare, encamped on shore and enjoyed the treat of talking with men of education and refinement.

The next day Audubon's party embarked in three boats and visited a harbor - Mecat- 


\section{AUDUBON'S LABRADOR TRIP}

tina Harbor - a mile to the eastward where the crew of a whaling schooner were engaged in trying out blubber, and they called on a French-Canadian seal-catcher who gave them much information about various fur-bearing animals. In his "Episode" on "The Squatters of Labrador" he refers to this man as Pierre Jean-Baptiste Michaux. The latter's cabin was in a sheltered nook where, to his surprise, Audubon found the atmosphere quite warm, vegetation luxuriant, and the winter wren, white-crowned, fox, and Lincoln's sparrows, the Wilson's warbler, and horned lark in full song.

On July 23 the party visited the seal establishment at Sparr Point of Samuel Robertson, a Scotchman, who had lived there for twenty years. He was lord of the region, and well contented with his lot; his profits from seal oil and furs amounted the previous year to $£ 600$.

On July 23 they set sail from Baie de Portage, intending to call on Chevalier at St. Paul's River, but, on account of unfavorable weather; were unable to do so. They found themselves that evening off Bonne Espérance; 


\section{IN AUDUBON'S LABRADOR}

"but as our pilot knew as much of this harbor as he did of the others, which means nothing at all, our captain thought prudent to stand off and proceed to Bras d'Or," which they reached the following morning. Here the sealfishing establishment of Mr. Jones was visited afterwards so interestingly described in the "Episode" already referred to, and much information on the birds and beasts and people gathered. Here it was that Audubon at last succeeded in finding the nest of the horned lark, long sought in vain, and he makes a tantalizing record of the now extinct pied or Labrador duck as follows: "The Pied Duck breeds here on the top of the low bushes, but the season is so far advanced we have not found its nest."

At noon on August I they "were visited by an iceberg, which has been drifting within three miles of us, and is now grounded at the entrance of the bay; it looks like a large manof-war dressed in light green muslin, instead of canvas, and when the sun strikes it, it glitters with intense brilliancy." Two days later the Wizard, commanded by Captain Wilcomb, of Ipswich, which had anchored near, broke her stern chain in a gale, collided with the 


\section{AUDUBON'S LABRADOR TRIP}

Ripley, and stove in their "beautiful and most comfortable gig." However, the vessels were soon parted without further damage. On this day, August 3, the Eskimo curlew, now almost extinct, appeared from the north. "This species here takes the place of the Migratory Pigeon [alas, now entirely extinct]; it has now arrived; I have seen many hundreds this afternoon, and shot seven. They fly in compact bodies, with beautiful evolutions, covering a great extent of country ere they make choice of a spot on which to alight; this is done whereever a certain berry called the 'Curlew berry' proves to be abundant. Here they balance themselves, call, whistle, and of common accord come to the ground, as the top of the country here must be called. They devour every berry, and if pursued squat in the manner of Partridges. A single shot starts the whole flock; off they fly, ramble overhead for a great distance ere they again alight. This rambling is caused by the scarcity of berries. This is the same bird of which three specimens were sent to me by William Oakes, of Ipswich, Màss."

On August Io the party visited Perroquet 


\section{IN AUDUBON'S LABRADOR}

Island, near Blanc Sablon, the breeding-place then as now of puffins or perroquets.

In great spirits he enters in his Journal on the same date the following: "Who, now, will deny the existence of the Labrador Falcon? [Black or Labrador gyrfalcon.] ${ }^{1}$ Yes, my Lucy, one more new species is on the list of the "Birds of America,' and may we have the comfort of seeing its beautiful figure multiplied by Havell's engraver. This bird (both male and female) was shot by John whilst on an excursion with all our party, and on the 6th inst., when I sat till after twelve o'clock that night to outline one of them to save daylight the next day to color it, as I have done hundreds of times before." While at Bradore, the party visited Blanc Sablon, and some of the young men walked as far east as Forteau, which he enters in his Journal as Port Eau.

On August II they put to sea,- " "Seldom in my life have I left a country with as little regret as I do this"; and two days later they

1 In the original plates the black gyrfalcon, called obsoletus by Gmelin in I788, is figured, while in The Birds of America, although the details of the capture of the birds in Labrador are given, the bird, is described and figured as the Iceland gyrfalcon. 


\section{AUDUBON'S LABRADOR TRIP}

anchored at St. George's Bay, Newfoundland. Here "the temperature changed quite suddenly, and this afternoon the weather was so mild that it was agreeable on deck, and congenial even to a Southerner like myself." Here they explored and collected and disported themselves at a ball, where John Woodhouse Audubon played the violin till half-past two in the morning. After four days of sea-sickness they reached Nova Scotia and rejoiced mightily as they smelt the odor of new-mown hay and heard the music of the crickets. Leaving the schooner, they walked full of joy among familiar surroundings to Pictou and put up at the "Royal Oak." In Pictou they saw much of Professor McCullough. Thence they went by coach to Halifax where, from walking about to see the town, "all have aching feet and leg-bones in consequence of walking on hard ground after tramping only on the softest, deepest mosses for two months." Leaving Halifax, they journeyed by coach to Windsor, saw the wonderful Bay of Fundy tide, and took the Maid of the Mist to Eastport. "Here we were kindly received by all our acquaintance; our trunks were not opened, and the new clothes 


\section{IN AUDUBON'S LABRADOR}

'paid no duties; this ought to be the case with poor students of nature all over the world." A week later, on September 7, I833, Audubon reached New York, " and, thank God, found all well."

This arduous trip was well worth all its hardships. Audubon brought back seventÿthree bird-skins, as well as a large collection of plants and of other natural-history objects. He observed in all some ninety-three different species of birds, and recorded much that was hitherto unknown. A new species, Lincoln's sparrow, was discovered and described, and twenty-three drawings of the birds were completed or nearly completed. He worked hard and has been well rewarded. 


\section{CHAPTER II}

TO THE STARTING-POINT

TNSTEAD of going by way of Eastport, 1 Maine, as did Audubon, my companion and I took the night train to Montreal. WeMr. Harold St. John, botanist, and myself, ornithologist - became for the time being members of the staff of the Canadian Geological Survey, each in his own line to make studies and reports. With my friend botany was a profession; he had taught the subject at Harvard College, and he was to become a permanent worker in the Canadian Survey. In my own case the study of natural history in general and of ornithology in particular was merely a lifelong hobby.

The steamship Cascapedia took us down the great river St. Lawrence the afternoon of June 24, I9I5, under the care of Captain Hearn. He was an old friend of another trip and, as I sat next to him at table, I had the full benefit of his wise and witty sayings and sea-tales. We were speaking of Sable Island, 


\section{IN AUDUBON'S LABRADOR}

and the botanist was enthusiastic about a trip he had taken to that out-of-the-way spot, when the captain said, with much emphasis, "Any one who would go to Sable Island for pleasure would go to hell for pastime"; and added, "You fellows are all tarred with the same brush - you're never happy unless you 're in some d-d wilderness."

The next morning early we had a couple of hours ashore at Quebec, and, besides wandering about the old town and reveling in the wonderful view from the Terrace, we enjoyed an impressive service in the dimly lighted cathedral. Regular life on board the boat now began, and we found an interesting company, as is apt to be the case on out-of-the-way journeys. I particularly enjoyed long talks with Napoleon A. Comeau, the veteran naturalist of Godbout, an authority on the lifehistory of our salmon, and an ornithologist of no mean attainments. He gave me an account of his trip the previous summer to Hudson Bay, and of the birds he had found on the western side of the Labrador Peninsula. Another of our passengers, who left us at Trinity, was a Scotchman who, morning, noon, and 

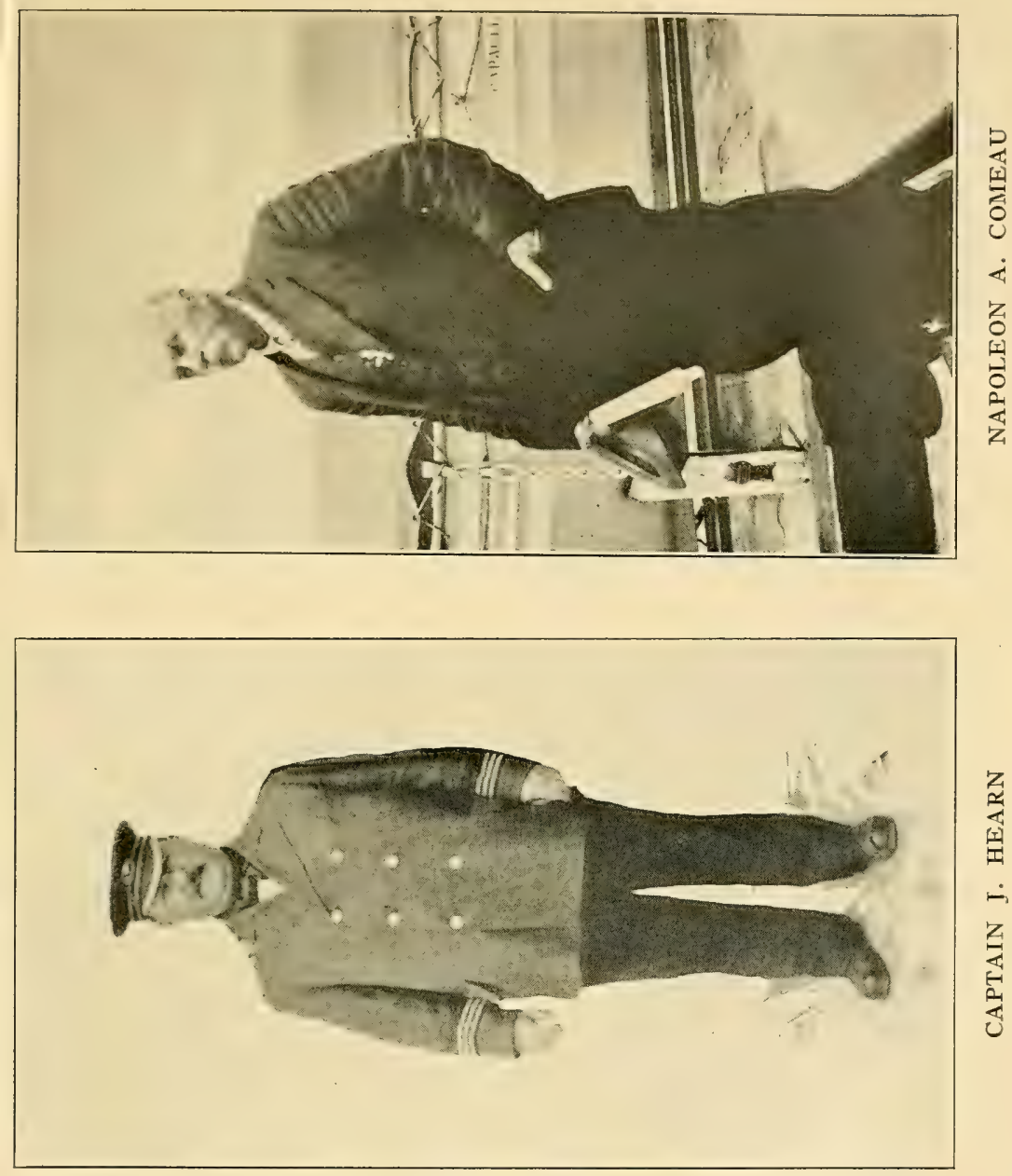

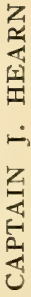



night, paraded the deck playing the bagpipes. At first disposed to laugh at the performance and to regard it as of a low order, I finally became much impressed with the variety and interesting character of the music, which he played with much artistic feeling and appropriate steps. His pieces ranged from light to mournful, from jigs to pibrochs. Dr. McDuff, the successor of the late Dr. Tremblay, of Esquimaux Point, was of our company, as was also Dr. West, who was to take Dr. Hare's place at the westernmost Grenfell mission at Harrington.

The captain introduced a term new to me when I asked him what the men did at one of the small stopping-places. "They are mostly hot-rockers here," said he; and when pressed for an explanation, replied, "Oh, the men are too infernally lazy to fish, so they lie down on the hot rocks." I also heard him tell again the tale of the first captain under whom he served as mate. This man navigated by a demijohn of rum, whose depth he plumbed from time to time with a stick. At last a point was reached where the captain judged it would be well to take an observation by the sun. 


\section{IN AUDUBON'S LABRADOR}

It was a beautiful afternoon when we entered the wonderful Bay of Seven Islands. They were having a good season at the whale factory, but no whales were to be seen and we were too far to windward to perceive the usual evidence of them. At Clark City Wharf - the port of the wood-pulp factory eleven miles distant in the forest - we landed one of the Clark brothers and listened to talk about the management of the men and pulp production. I also had the pleasure of hearing the songs of a Tennessee warbler, a whitethroated sparrow, and a hermit thrush, while my companion filled his box with flowers.

This bay is of great interest to the ornithologist, as here brant collect in immense numbers in the spring preparatory to their long flight across the base of the Labrador Peninsula to James Bay. Unlike most water-birds, which skirt the coast in the migrations, they make this short cut across the land. While resting in the bay they feed on the eel-grass, which grows here in great profusion. Eel-grass also is a favorite diet of the Canada goose, and it is called on the coast herbe outard, for the Canada goose is known here as l'outard, a name used by 
Champlain and other early explorers. The name outard signifies bustard, a very different bird, but, in the old French of Champlain and the modern Acadian it is applied to the wild goose.

The Bay of Seven Islands is close to the western limit of the Labrador Peninsula. On modern maps one finds the name Labrador printed on a narrow strip along the eastern coast and the Straits of Belle Isle as far as Blanc Sablon. This is the part of the peninsula that belongs to Newfoundland. The northern part of the great peninsula is labeled Ungava, and the southern part Saguenay County, Quebec, but these are political divisions whose boundaries are artificial and are even now uncertain and under dispute. The great natural feature to which the term Labrador Peninsula belongs - an area according to Low of some 5 I I,000 square miles - has certain boundaries that are easily comprehended. On the north lie Hudson Straits, on the east the Atlantic Ocean, on the south the Straits of Belle Isle and the Gulf of St. Lawrence, and on the west James Bay and Hudson Bay. At various times the line marking off the neck of the pen- 


\section{IN AUDUBON'S LABRADOR}

insula has been drawn from the foot of James Bay to the mouth of the Saguenay, to Pointe du Mont near Godbout and to a point where the fiftieth parallel of latitude strikes the coast a short distance to the west of the Bay of Seven Islands. The latter boundary, nearly six hundred miles long, is the one now accepted. Aside from this one comparatively unimportant artificial boundary, the Labrador Peninsula is a definite and striking natural feature on the earth's surface.

The term "Labrador," one would think, might therefore be used for any part of the peninsula, but strictly speaking, it is often restricted to that part belonging to Newfoundland. This is often called "The Labrador." The inhabitants of the southern coast, however, commonly speak of Canadian Labrador as well as of Newfoundland Labrador and these terms seem to be convenient and easily understood. They are used by the Canadian Geological Survey. The northern part of the peninsula north of Hamilton Inlet, to the west of the coastal strip, should be known as Ungava Labrador. From a biological point of view it is a great convenience to use the term Labra- 


\section{TO THE STARTING-POINT}

dor for the whole peninsula, and it can be done without fear of confusion if the qualifying terms Ungava, Newfoundland, and Canadian are used. The population of this huge peninsula has been estimated to be fifteen thousand. This includes thirty-five hundred Indians and two thousand Eskimos. The interior is inhabited by the Indians alone; the whites and Eskimos live only on the coast. The population in summer is increased by about twenty-five thousand Newfoundland fishermen who visit the eastern and southern coasts.

At the town of Seven Islands, which contains a Hudson's Bay Company's post, an Indian village, and the seat of the Bishop of the Catholic missions of the coast, we ran aground attempting to reach the newly built wharf. We backed out, anchored, and waited a couple of hours for a higher tide. One would have thought it was a band of emigrants that huddled together for shelter on the wharf at ten that night, but it was only a party of ladies and gentlemen and a charming baby going to a salmon-fishing camp on Trout River. Mr. William Kakas, well known on this coast as a fur-trader, also disembarked here. 


\section{IN AUDUBON'S LABRADOR}

At Ellis Bay, Anticosti, on the fourth morning of the voyage from Montreal, we landed the enterprising manager of lumbering interests for M. Menier, the feudal lord of this great island. Some ten years before, this young man, a New Yorker, heard that the island of Anticosti, one hundred and forty miles long by thirty broad, was for sale, and tried to interest an American millionaire in it, but failed. Henri Menier, the chocolate king of France, heard of it and cabled the young man to meet him in Paris. The interview resulted in the purchase of the island and the establishment of the New Yorker as manager of lumbering interests, a position he has since held. With his family he spends his summers at Anticosti, his winters in New York. Henri Menier died and the younger brother, Gaston, was at the island in I9I4 when the war broke out. $\mathrm{He}$ hurried back to France to find his château in the possession of the Germans. From our point at anchor we could see the storehouses, the manager's house, and the Menier mansion; this from a distance did not look particularly impressive until we were told it contained eighteen bathrooms. The manager, with his 
wife, four children, assistants, servants, and baggage, made up a picturesque company as they went ashore in a large ship's boat under sail.

We were soon back on the Côte Nord and dropped anchor from time to time off familiar places, ${ }^{1}$ to be met by fishing-boats for the exchange of passengers and commodities. Splendid twenty-pound salmon were to be bought for fifty cents. Our conversation was of the coast and its interests and life. We rarely referred to the war - it seemed to be only a memory and a bad dream, a thing of the past or of some other world from which we had severed our connection, as indeed we had. It was a refreshing relief. Mount St. John stood up dark blue and sharply cut in its long and irregular outline against a cloudless sky as we anchored that evening off the mouth of the St. John River. Near at hand lay the Wacouta, James J. Hill's white steam yacht, awaiting her owner at the salmon club.

We arrived at Esquimaux Point late on the evening of June 27 , and found our pilot of

${ }^{1}$ See A Labrador Spring for description of this part of the coast. 


\section{IN AUDUBON'S LABRADOR}

the trip, Captain A. Edmond Joncas, and his schooner the Sea Star. M. Johan Beetz, who had courteously invited me to pay him a visit at Piashte Bay, - now officially known as Bay Johan Beetz, - also came to meet us on the wharf. Although the botanist was hospitably included in the invitation, he decided to stay a day at Esquimaux Point to investigate the flora of that limestone region, and come on later in the Sea Star.

The next morning found me embarked in the little mail schooner with $M$. Beetz en route for his house, of which I had such pleasant memories of six years before, when $\mathrm{Mr}$. A. C. Bent and I passed a day there and were royally entertained. M. Johan Beetz, a native of Brussels and a man of education, came to this coast twenty years ago for a summer's sport, was charmed by the place, spent the winter at Piashte Bay, married the young telegraphoperator of that tiny village, and, with the exception of trips with his family to Europe, has stayed there ever since. $\mathrm{He}$ is a pioneer in the black fox industry, and, when I was there six years ago, he had seven parks of these animals; now he has twenty-one. On the mail 

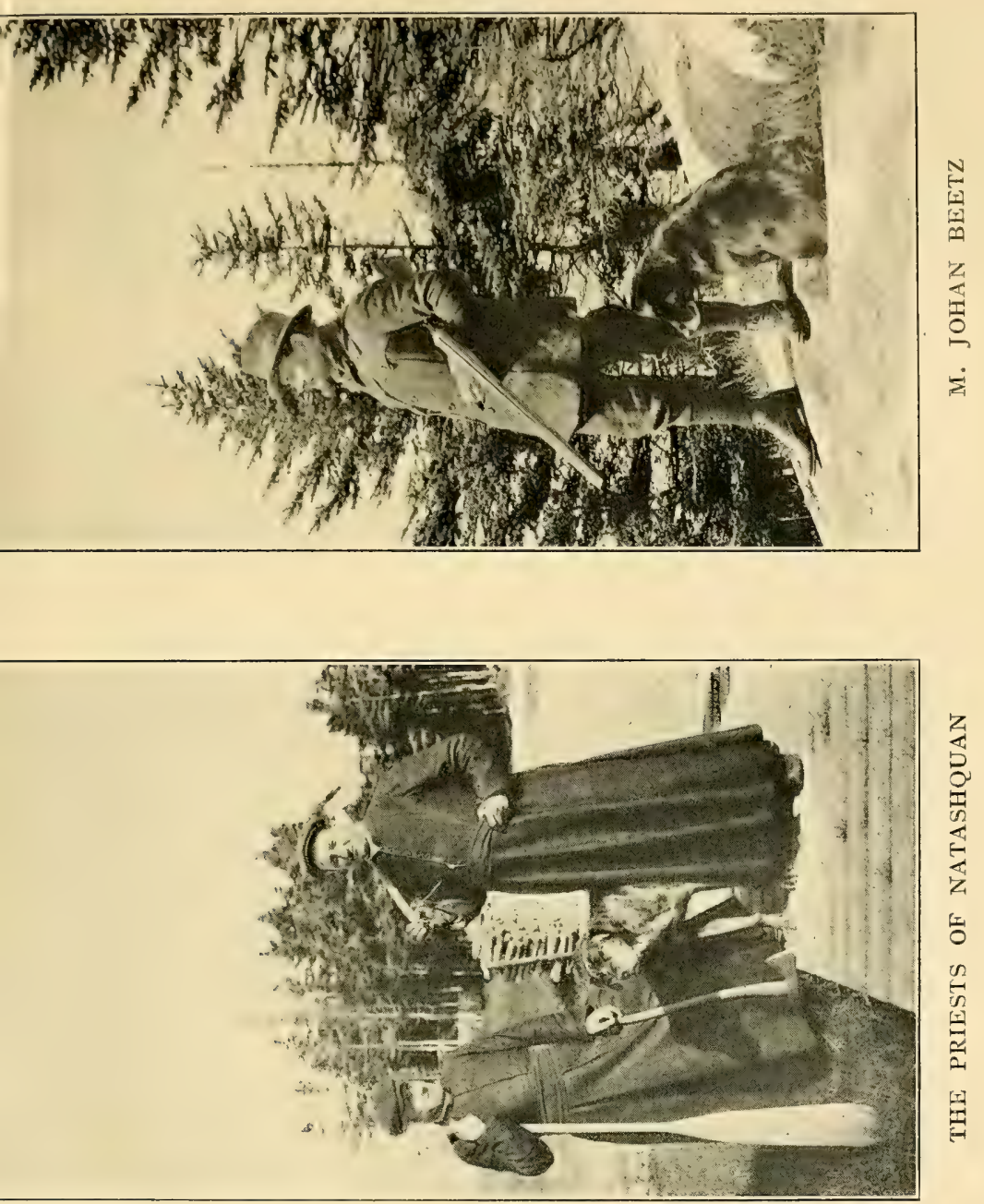

schooner the flag of France flew at the foremast, that of England at the mainmast. Here, at our host's house, the flags of England and of Belgium were on the flagstaff. Hard, indeed, is it on those whose heartstrings are tied to Belgium!

The family is a charming one. Of the master and his versatile nature I have already written in "A Labrador Spring." $\mathrm{He}$ is a delightful companion, full of fun, agile in mind, spirits, and body. His wife presided with great dignity, sweetness, and charm of manner over an interesting family of six, from Johan le jeune, aged sixteen, to Henri, aged eighteen months. Their pleasant voices, great politeness, and affectionate regard for each other will always make this visit one of the pleasantest memories of my life. 6. The house, one of the largest and most comfortable along the whole length of coast, is built on the rocks beside a rushing salmon river whose music was always in our ears. In front is the bay with its rocky islands, behind, the lakelike expansion of the river backed by the hills and the spruce forest, while near at hand is the little village with its half-dozen houses and small chapel. 


\section{IN AUDUBON'S LABRADOR}

We were not entirely cut off from the world here, for every day there arrived a carefully worded telegram about the war sent by the Government to all the stations on the coast. This message is in French as far as Harrington; and beyond this station it is translated - with some loss of sense - into English. The telegraph-line, a single wire built and maintained by the Government, struggles along this rocky coast as far as Chateau. Beyond that to Battle Harbor and along the eastern coast communication is had by wireless stations. The character of the war news was generally delphic and non-committal, but it occasionally was most encouraging, and we were all greatly cheered.

The table was of the best, - delicious salmon, - and he who has not eaten salmon fresh from the Northern rivers knows it not, - trout, capelin, lobster, seal-meat, canned rabbit, and, from the garden, cress, radishes, turnip-tops, chives, and dandelions. Seal-meat is a dark, almost black meat, but surprisingly tender and well flavored. There is no suspicion of a fishy flavor, but rather a suggestion of mutton or venison. It is certainly an excellent meat, but 
like many other foods on the coast is not appreciated, for it is rarely eaten by man, but, after the skin and blubber are removed, it is thrown away or fed to the dogs.

Capelin is a small fish about the size of a smelt and is delicious eating when fresh. It is also good when slightly salted and dried. In the latter state it is heated in the oven or on top of the stove and eaten whole. Canned rabbit is also to be mentioned with respect, for M. Beetz employed a most expert canner and thus enjoyed many foods out of season. His snow cave or cold-storage plant was also well stocked with game.

Turnip-tops make excellent greens and are used when the young turnips are thinned. Later, at Natashquan, I was amused to find that the beet-tops were thrown away from ignorance of their value, although the turniptops were used. Here at Piashte Bay the vegetables already mentioned grew, as well as rhubarb, carrots, onions, and green peas. M. Beetz's garden was neatly laid out in small plots of rich black, peaty loam brought from an island where sea-birds nested. It looked like the garden of an experiment station, as 


\section{IN AUDUBON'S LABRADOR}

the plots were so small, so regularly arranged, and so free from weeds.

A white-crowned sparrow was nearly always to be seen in the garden gathering insects and grubs. Its family was securely hidden in a nest under some fir trees close to the house. His, or her, - for the sexes are alike, - white crown with black stripes and neat slate-colored breast contrasted well with the black loam and green plants. This sparrow is certainly a dooryard bird. On the eastern coast I always found it more plentiful about fishingvillages. It often sang from the sod-covered roofs of the houses and occasionally from the spars of the schooners in the rocky harbors.

On the spring migration I have seen it within a few feet of the doorsteps of my house at Ipswich. Its song was frequently ringing out - a sad and beautful one. The syllables my friend Dr. Allen and I invented on the eastern coast some years before to memorize it, seemed still to fit, although they give no idea of its wild beauty. These syllables are, more wet, wetter wet chezee. It is probable that Piashte Bay is about the extreme western breeding 
limit on the southern coast of this bird of the Hudsonian and sub-Arctic zones.

Fortunately for me the Sea Star was delayed by calms and easterly winds, so I spent five delightful days at Bay Johan Beetz. Many hours were taken up with the study of the splendid collection of the birds of the neighborhood which M. Beetz had prepared, and I found in it no less than six species new to the list of birds previously recorded from the Labrador Peninsula. These were Kumlien's gull, European widgeon, lesser scaup duck, kildeer plover, red-winged blackbird, and eave swallow. All were stragglers to this remote region, although Kumlien's gull must be of common occurrence on the eastern coast.

One day we went in canoes up the river salmon-fishing, but although I succeeded in hooking a large fish, the temptation to follow up the bird-voices I could hear in the distance was too much for me.

"Herkneth these blisful briddes how they singe

"Ful is mine herte of revel and solas."

I left my host in his canoe to catch four twenty-pounders, while I was paddled up the beautiful stream to the old Indian portage at the 


\section{IN AUDUBON'S LABRADOR}

falis. It was not that I loved fishing less, but birds more, and there have been so few who have studied the birds of this region. Warblers were common: black and white, Tennessee, yellow, magnolia, black-poll, and yellow palm, a water-thrush, and a few redstarts. A yellowbellied flycatcher gave his soft double whistle and an olive-sided flycatcher repeated vociferously, what-cheer. By the optimistic hunter this is rendered, three deer. Three years ago I had found the olive-sided flycatcher some fifty miles in the interior in the valley of the Natashquan River. With this exception the only previous record for the Labrador Peninsula is that of Audubon, who found it there in 1833 . The absence of the black-throated green warbler interested me. This is a common bird with us in New England whose song, Hear me, St. Theresa, coming from the tops of pines is a familiar one to bird-lovers. In the spring migration of 1906 I found this bird abundant along the southern Labrador coast, and in the summer of 1909 it was the most common warbler in the spruce forests of the interior in the lower valley of the Natashquan River. Now on this trip in the height of the breeding- 


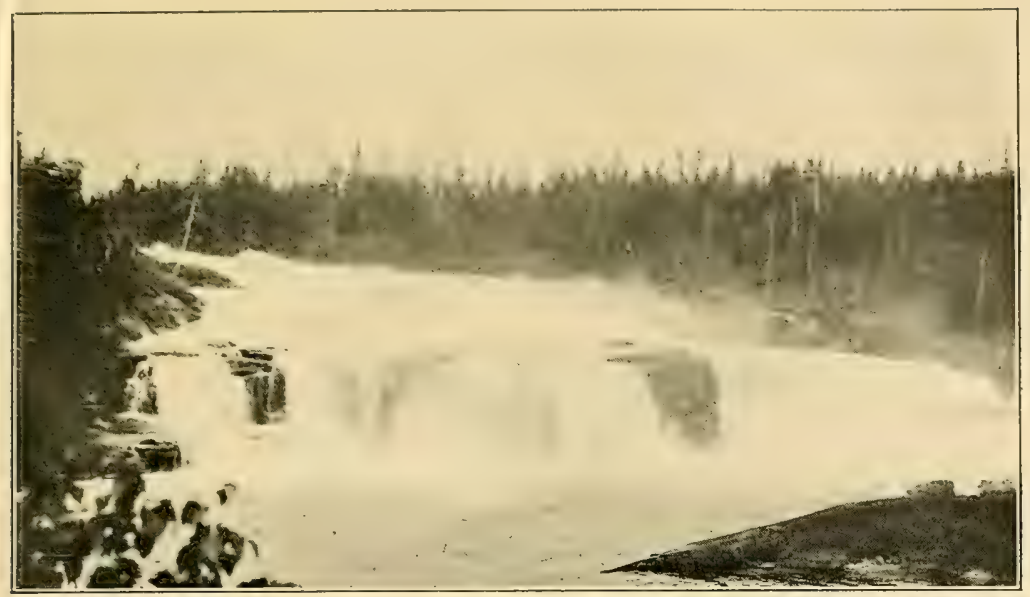

FALLS OF GRAND RIVER OF PIASHTE BAY

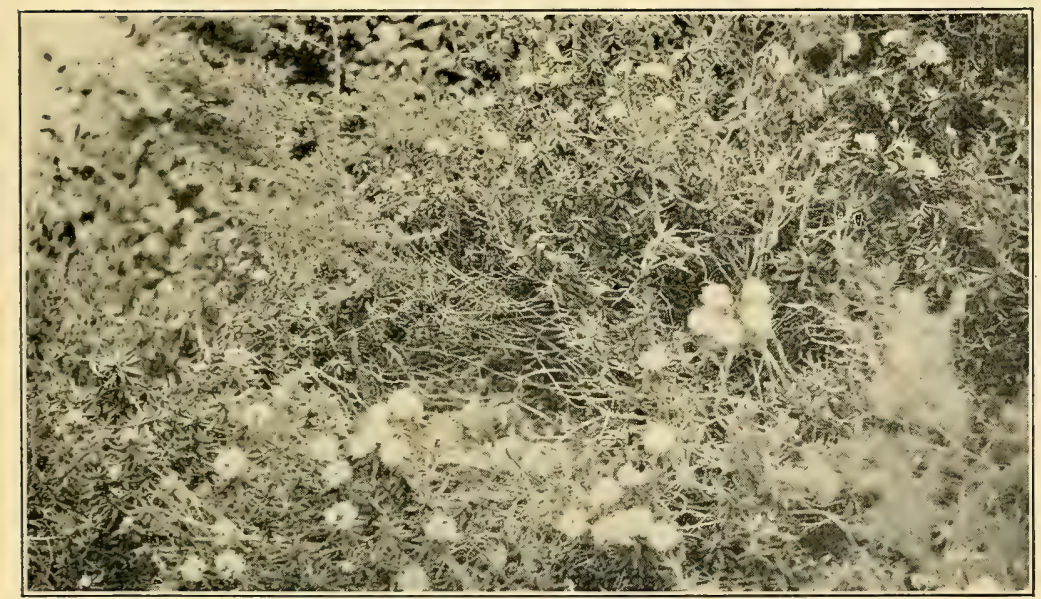

NEST OF RED-BREASTED MERGANSER: LABRADOR-TEA 



\section{TO THE STARTING-POINT}

season no black-throated green warblers were to be found at Piashte Bay or Natashquan, and it is evident that they pass through the coastal strip and breed only in the interior, which, although farther north, is warmer. The reverse is the case with the black-poll warbler, which breeds abundantly along the still colder, more Arctic coast to the eastward and is rare on the forested coast and in river valleys. Here at Piashte Bay it is not so common as on the coast to the eastward of Natashquan. The redstart, that bird with Belgian colors, black, red, and yellow, is more enterprising than the black-throated green warbler and nests on the coast. I have not, however, found it to the eastward of this point, but here it was in full song.

On the shore of a lakelike expansion of the river I startled a female red-breasted merganser or sheldrake - the bec-scie of the habitants - from a tangle of spruce and Labrador-tea. Here, about a dozen feet from the water and the same distance above it, was the nest, containing eight eggs, warm and well protected in a bed of grayish-black down. Near at hand swam a female black duck with her brood of downy young. 


\section{IN AUDUBON'S LABRADOR}

The Indian portage path led up through the thick spruce forest, which reverberated with the roar of the unseen falls, to the rocky ledges above. Over these the water dashed down for more than a hundred feet into a dark forest-girt pool, where the trees waved in the blasts and the smokelike spray rose in clouds. The great bounding waves seemed to poise in the air before the final plunge, and the roar was deafening. From a distance these foaming falls looked like a great patch of snow on the hillside.

On another occasion we sailed to some rocky islands and found the nests of great blackbacked gulls with their large spotted eggs, the nests of herring gulls, of common terns, and of eiders. In one of the latter, containing six olive-green eider eggs, there were four additional eggs laid by a black duck, smaller and of a drab color. All were smothered in the warm gray down plucked from the breast of the female eider whom we scared from the nest. As we rounded a point we came on several broods of eider ducklings with their mothers. One group of five dived repeatedly and scattered in all directions, while the mother 


\section{TO THE STARTING-POINT}

uttered an alarmed rasping croak and flopped about on the surface like a wounded bird. Later she flew ahead of the boat to entice us away from her dusky, downy youngsters.

Another time we were rowed to Grand Bay of Piashte Bay. It is a beautiful spot with rocky and wooded shores. A salmon-fisher had set his nets at the mouth of the river, and was living on his little schooner in a lovely cove well protected from the sea. The river flows around an island and forms two splendid falls, each about forty feet high, grand and impressive in the forest.

The Sea Star arrived on July 2, and early the next morning we were off, taking our host with us as far as Natashquan, which we reached that evening. On the way we passed Quetachoo, Watcheeshoo, Pashashiboo, and more of the same kind. Natashquan, formerly called American Harbor, is at the mouth of the Little Natashquan River. It was the starting-point of Audubon's Labrador trip. 


\section{CHAPTER III}

AMERICAN HARBOR, OR NATASHQUAN

A $\mathrm{T}$ Natashquan we went at once to the 1 house of the captain's brother, Richard Joncas, the head and whole of the "Labrador Fur Company," whose delightful hospitality and that of his wife I had enjoyed on my previous trips. Here, like Audubon, we were delayed by easterly winds and did not get away until July 7, but we both were well content, and explored the neighborhood as fully as possible for flowers and birds. The day after our arrival, July 4, we celebrated appropriately by some firecrackers produced from the store, which, like those of the Hudson's Bay Company, contained everything that an Indian's heart might desire. The botanist and I, fully equipped for our work, then started for the "post," five miles away. This was formerly the Hudson's Bay post, but it is now abandoned by the Company. Here, near the mouth of the Great Natashquan River, is situated the annual summer encampment of the 



\section{AMERICAN HARBOR, OR NATASHQUAN}

Montagnais Indians. In Audubon's time the post was situated on the eastern side of the river and Audubon went there by boat. Cartier found Indians here in $\mathbf{1 5 3 4}$.

We crossed the bridge recently completed over the mouth of the Little Natashquan River, and separated in the woods beyond, agreeing to meet for dinner on the beach about a mile from the post. Mosquitoes and flies, which at Piashte Bay were just beginning to come into their own, were now out in force and fully up to concert pitch. I am inclined to think that one is fortunate in entering a black-fly country in this manner before the vicious creatures reach their full powers, for the feeble bites early in the season are sufficient to produce enough resistance to the poison so that later the swelling that ensues is not severe. It is a sort of prophylactic inoculation.

For both of us this was an interesting walk. The wonderful flutelike song of the fox sparrow was ringing in our ears. It is a splendid song, that of a well-trained performer who is contented with his powers and does not try to vary his theme. It lacks, however, the feeling of the simple song of the white-throated 


\section{IN AUDUBON'S LABRADOR}

sparrow and does not, of course, compare with the hymn of that serene and heavenly singer, the hermit thrush. Nor is the song as interesting as that of the Lincoln's sparrow. I have already quoted Audubon's record in his Journal of his discovery of the Lincoln's sparrow at Natashquan. He named it after one of his young companions, Tom Lincoln. It is fairly common all along this coast and takes the place here of the song sparrow, which it closely resembles and of which it is a near relative. When one has thoroughly grasped the slight differences in the shade of color and in the markings, one can readily distinguish the two birds. The markings both on the breast and back are finer in Lincoln's sparrow, the color of the back is more olive and the front of the breast is washed with buff. Unlike the song sparrow, he is not social in his disposition, but very shy, and easily eludes the sight even when he is singing. The song is one of considerable beauty and great range of theme. At times I have recognized the general character of the melody of the song sparrow, at times the jingling notes of the song of the winter wren, at times the impassioned warble of 


\section{AMERICAN HARBOR, OR NATASHQUAN}

the purple finch. It generally has a loud ringing character like the music of silver sleighbells with the interpolation of fine trills and deep flutelike notes. One bird I especially loved at Piashte Bay often ended his song with Oh mieux, and occasionally followed it with an almost inaudible trill which sounded as if he were drawing in his breath after the supreme effort. It is an interesting and cheerful song, one which I always listened to with great pleasure.

Audubon says in his Journal, "The note of this bird attracted me at once; it was loud and sonorous." In his "Birds of America" he describes his first encounter with this new species in a valley of beautiful verdure at Natashquan: "But if the view of this favoured spot was pleasing to my eye, how much more to my ear were the sweet notes of this bird as they came thrilling on the sense, surpassing in vigour those of any American Finch with which I was acquainted, and forming a song which seemed a compound of those of the Canary and Wood-lark of Europe. I immediately shouted to my companions, who were not far distant. They came, and we all followed the 


\section{IN AUDUBON'S LABRADOR}

songster as it flitted from one bush to another to evade our pursuit. No sooner would it alight than it renewed its song, but we found more wildness in this species than in any other inhabiting the same country, and it was with difficulty that we at last procured it. Chance placed my young companion, THomas LiNCOLN, in a situation where he saw it alight within shot, and with his usually unerring aim, he cut short its career. On seizing it, I found it to be a species which I had not previously seen; and, supposing it to be new, I named it Tom's Finch, in honour of our friend LINCOLN, who was a great favourite among us. Three cheers were given him, when, proud of the prize, I returned to the vessel to draw it, while my son and his companions continued to search for other specimens. Many were procured during our stay in that country."

Another bird, whose song, far from beautiful, may be represented by the syllables je-let rendered in a harsh and jerky manner, was not uncommon. It has also a pleasing call-note, a double whistle so much like the common note of the wood pewee that I am convinced that when Audubon said in his Journal at 


\section{AMERICAN HARBOR, OR NATASHQUAN}

Natashquan, "I heard a Wood Pewee," he had in reality heard this bird. In fact, the yellowbellied flycatcher, a bird of about the same size and appearance as the wood pewee, but with a faint tinge of yellow below, was not recognized till some years later by Baird, and the wood pewee is not known to extend so far north as Labrador. It is interesting to note that seven years after Audubon's visit to Labrador he received a modest letter from Baird, then a young man, describing this flycatcher, and venturing to think it was a new species. With this thought Audubon at once acquiesced.

I could delay for hours on the ornithological interest of this walk, and the reader may wish that the mosquitoes had got the better of me; I cannot, however, refrain from speaking of the Tennessee warbler, a bird apparently overlooked by Audubon in these regions. In his "Birds of America" he says of this species, "Of its migrations or place of breeding I know nothing." Its song was sufficiently common along the coast, but in former trips I had caught but fleeting visions of the bird, which, like Lincoln's sparrow, was more often 


\section{IN AUDUBON'S LABRADOR}

heard than seen. One exception should be made to this statement, for two Tennessee warblers came on board the steamer in a fog when I was returning from one of my trips and here they could be watched from a few feet. I find from my notes that in the five days spent at Piashte Bay I did not once succeed in seeing the bird. On one occasion I followed one about for over half an hour in a low spruce thicket, where it sang frequently and occasionally chipped within what seemed to be a few feet of me, but try as I would, I could not get even a momentary glimpse of it. Here at Natashquan the bird was really abundant, and several times it appeared in full sight when it sang.

Its song is loud and clear, businesslike and unattractive. In its entirety it may be divided into three parts, each part a repetition of similar notes, and it may be expressed as follows: sst, sst, sst, - twa, twa, twa, - tsweet, tsweet, tsweet. The third part is sometimes omitted and the first part is rather faint and cannot be heard at a distance; the middle part is at times almost pleasing in its quality and is loud and clear. 
This was the warmest day we had experienced, and although it was only $54^{\circ} \mathrm{F}$. in the morning and $62^{\circ}$ at noon, yet in that part of the world it was considered sultry. After a bath in the sea, the remembrance of the flies and mosquitoes was happily washed away, and erbswurst, dried capelin, bread and cheese, and chocolate made us contented with the world. From time to time Indians, who had been to church at Natashquan and had afterwards traded at the store, came along the beach and passed us as we sat cross-legged around the fire. Usually they scudded shyly by like sandpipers, but occasionally they stopped to gaze on us, say bon jour, and various incomprehensible words. I felt that the usual state of affairs was reversed and that I and not the Indian was on exhibition. Later I suddenly came across a picturesque group of Indian girls picking last year's mountain cranberries. This berry is called in Newfoundland partridge-berry, but here is known as graine rouge or pomme de terre. The latter singular name is rendered possible by the fact that potatoes are called potates in the Acadian dialect of this coast. The berry after the win- 


\section{IN AUDUBON'S LABRADOR}

ter's cold is delicious eating, as it has lost much of its sharp acidity and it has a very pleasant taste. It is gathered in the fall in large quantities, keeps a long time in water, and can be bought in Quebec for twenty-five cents a gallon. In Newfoundland it has become such a valuable asset that a botanist was brought from Harvard a few years ago to study the possibilities of the berry. Besides its use for native consumption, it is sent largely to the Norwegians in the northwestern part of the United States.

After dinner we visited the Indian encampment at the mouth of the Great Natashquan River and were received by a rush and chorus of Indian dogs. These dogs are very different from the Eskimo dogs and are much smaller. They are long-haired with pointed noses and ears and curled-up tails, and are generally black and tan in color with white bellies and white tips to their tails. While the Eskimo dog is quite close to the timber wolf in origin, this Indian dog is probably of smaller, Asiatic stock. I was on the lookout for a skull of this animal for a friend who wished to make a comparison with certain Asiatic specimens as well as with 




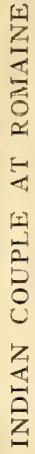

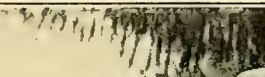

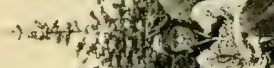

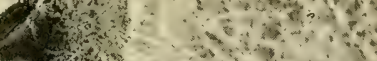

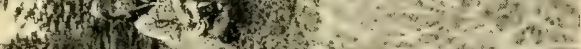


- ant why

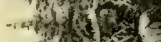

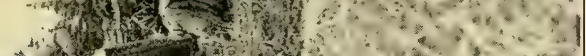
a.

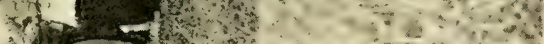

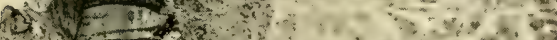



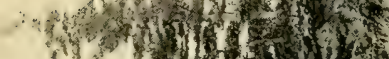

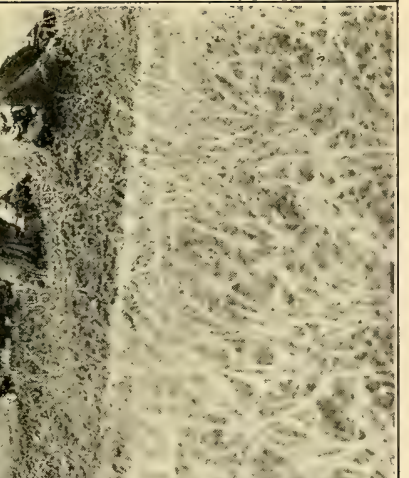

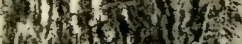

\&

侌方

范

पू

点。

$6 \frac{1}{2}$ 



\section{AMERICAN HARBOR, OR NATASHQUAN}

specimens found in Indian shell-heaps in New England, but was unsuccessful. There were thirty-three families of Indians here, domiciled for the most part in "A" tents. The old wigwam and the oval tent formed of a framework of willow and spruce, both of which I found so common six years ago, seemed to be given up for this more practical but less picturesque white man's tent.

These Indians are of the Montagnais or Mountaineer tribe of the great Algonquin family. All, as in Audubon's time, wore for the most part white man's clothing, but there was nevertheless a charm and picturesqueness about the dress and general bearing of these people. The women wore short, variously colored skirts, brilliant handkerchiefs about their necks, and caps of alternate stripes of black and red broadcloth with embroidered bands. These caps - their Indian name is acunishuan - were shaped like a French liberty-cap, and their peaks were drooped jauntily in front or over one ear. The women's black hair was tied in knots the size of hens' eggs in front of each ear. Hind, who was in these parts in I86I, pictures, in his "Explorations 


\section{IN AUDUBON'S LABRADOR}

in the Interior of the Labrador Peninsula," the same fashion of cap and hair. When one considers the expense, trouble, and heartbreaks that the white sisters of these Indian squaws have experienced since this date in following the innumerable changes of fashion as regards hair-dressing and head-gear, one cannot but admire the Indian's wisdom in retaining without change a fashion at once attractive and sensible.

All the women wore on their breasts crosses or crucifixes, many of them of polished silver of considerable beauty and value. Both men and women wore rainbow-colored woolen stockings, knit by the white women of the coast, and low moccasins or tall sealskin boots. White canvas jackets were generally adopted by the men, who often wore their straight black hair cropped below their ears. The young of both sexes were fine-looking, with dark olivebrown skins and ruddy cheeks; their eyes were black and sparkling. Their features were finely cut, their hands and feet small, their frames lithe and active. Some of the girls possessed considerable beauty. The older people, from whom the glow of youth had passed, 
AMERICAN HARBOR, OR NATASHQUAN

were dark and wrinkled and not so attractive.

The Indians usually spend the whole winter, from the latter part of August till May, hunting in the interior. They migrate up and down the great rivers and by well-trodden portage paths. Thewinter before many had to come out early on account of the scarcity of game. In the summer months they trade their furs for necessaries and luxuries, attend to their religious duties at the Catholic missions, and spread along the coast feasting on sea-birds and their eggs.

On our way back we noticed near the beach the pale blue-green leaves of the lungwort just appearing. This plant makes mats of foliage close to the sand and bears pink, changing to sky-blue, flower-bells. It is called on this coast vie toujours, and with it is connected a pleasing bit of folk-lore. It appears that it is a common habit for a young girl to take two branches of this plant and pin them by the middle perpendicularly against the wall. As they wilt, they bend either towards or away from each other. If the former, the young man will marry her; otherwise not. The captain, 


\section{IN AUDUBON'S LABRADOR}

who gave us this information, admitted that in passing through a room he had often given the boughs a slight twist to aid fate.

That evening, while I was skinning a bird surrounded by all the party at Richard Joncas's house, there came a sharp knock at the door. The captain's son Paul cried, "Entrez," and went out to the kitchen to return with a telegram - the daily news of the war. M. Beetz opened the envelope and his face fell. He then read it aloud. It began, "Nouvelles très sérieuses aujourd'hui. Les États Unis ont déclaré la guerre à l'Allemagne," and went on to say that the harbor of New York was blockaded by German submarines that had already sunk eight steamers; that an uprising of Germans in Chicago and other cities was imminent, and so on. I kept on skinning the bird, but did a good deal of thinking, and finally said, "I suppose I had better go back by the next steamer." At this they all burst out laughing and said it was a fake. The relief was great, and I gave vent to my feelings by pursuing the prime conspirator with an uplifted chair. M. Beetz was in his element; he is famous for his practical jokes, and this one 


\section{AMERICAN HARBOR, OR NATASHQUAN}

will undoubtedly be told with much gusto along the coast for years. One of his jokes is to unscrew the top of the salt-cellar at his table and the unsuspecting guest gets a large supply of salt. It is said that shy individuals have eaten their briny soup rather than call attention to their unexpected awkwardness. A fisherman, dining with him one day, was passed a plate containing pieces of cheese; he took the plate. His host then had cream and then some jelly passed him, all of which he spread on the cheese, thinking it was au fait, and, with a fisherman's appetite, he ate it all.

The next day we all went to a beautiful rocky, spruce-covered island at Watchechu, some twelve miles distant. This Richard Joncas wished to buy through his brother, the captain, who, besides being game warden for the entire southern coast as far as Blanc Sablon, is also Crown lands agent. These islands can generally be bought for five dollars an acre. M. Beetz showed his proclivity for practical jokes by putting a fish in one of Richard's rubber boots, and he led me to think we were striking rocks when we were going through a narrow place between islands by suddenly 


\section{IN AUDUBON'S LABRADOR}

jumping up and down in the stern of the boat. It was an interesting island, and we found eiders and great black-backed gulls breeding there. Paul, out of kindness to the botanist, brought him a branch of Labrador-tea, a plant which grows in profusion everywhere. Paul had never really looked at it before, and was struck with the beauty of its flower-clusters and its long narrow leaves with rusty woolly lower surfaces. He assured me - incredible as it may seem - that he had never seen this flower before and thought, as he picked it, that it was something unusual. It was a marked illustration of a common and well-known fact that most of us have eyes and do not see. A still more striking instance is worth narrating here. A college friend of mine who had lived since graduation on Cape Cod, wrote me that a book I had sent him "recalled an odd illustration of observation and its lack. I was asked to secure for an Amherst Agricultural Professor some beach peas. I had never heard the name, but I remembered that when a boy I had seen something at a certain place in Woods Hole, which must have been the desired plant. The next day I ran across the 
same plant at Truro, and later found it in profusion on my own beach. Now I must have been walking all over it every year, and the only time I had really seen it was over forty years ago." My friend devoted himself to the classics in college.

That afternoon I followed Audubon's steps up the bank of the Little Natashquan River to the falls. In the lower part of its course there are brackish marshes of small extent. I cannot call them salt marshes, for they lack the characteristics of these common features of the New England coast. Although a number of salt-marsh grasses grew there, - noticeably a form related to our black-grass, silver-weed and even the blue iris and other plants of brackish regions pushed their way almost to the water's edge. In fact I have never found any true salt marshes on the Labrador coast, and do not believe that salt marshes of any size can exist, except on a slowly sinking coastline. In Massachusetts, where there are good reasons to believe the coast has been sinking at the rate of one or two feet a century, extensive salt marshes abound. These build up at the same rate so that their rela- 


\section{IN AUDUBON'S LABRADOR}

tion to the sea-level remains always the same. Where the land is rising, as it is in Labrador, the formation of salt marshes is impossible, because the plants of the various zones of the salt marshes are very sensitive to conditions, and cannot maintain them as they do where the land is sinking at the same rate that the marsh is building up. In other words, the relation of the salt marsh to sea-level is always the same on a slowly sinking coast, but changes on a rising coast to such an extent that continued salt-marsh growth is impossible. If the position of the lands were stable, - neither rising nor sinking, - the buildingup of the salt marsh would gradually lead to a stealing-down of land vegetation and its own almost complete obliteration. In a word, then, the presence of extensive salt marshes would always indicate a coast of slow subsidence. ${ }^{1}$

The evidence of the rising of the land above the water is very marked here on the Labrador Peninsula. In places, as we shall see later in this narrative, one may find two or more sea

1 For a discussion of this subject, see my Sand Dunes and Salt Marshes, pp. 206-28. 


\section{AIIERICAN HARBOR, OR NATASHQUAN}

beaches of rounded pebbles elevated from fifty to two hundred feet above the sea and looking almost as fresh as if just left by the tide. Fish-stages built fifty years ago on the eastern coast are in places now barely accessible from the water in boats. Mr. Comeau told me of finding the remains of an old whale or seal establishment on an inlet so far from the salt water that he could not approach it even in a canoe. On the southern coast in sandy regions there are banks of marine sands cut by rivers many miles inland. At the mouth of the Great Natashquan River are low sandcliffs eight or ten feet high. Some seventyfive miles inland I found cliffs of the same marine sand over one hundred and fifty feet high - the cliffs known by the Indians as Tishkatawaka, or "cut up straight." Back of the beach at Natashquan are parallel ridges which represent ancient shore-lines. Similar sand-ridges occur miles inland and are elevated high above the sea.

The harbor of Natashquan in Audubon's day, although shallow in places, was doubtless deeper than it is now. Captain Joncas's father, who came to the coast as a trader with the 


\section{IN AUDUBON'S LABRADOR}

Indians in 1852 , used to sail close to the shore in a schooner where now are rocks and sandbars, and but a few feet of water except at the highest tides. Shifting sandbars of course explain part but not all of this change of level. The bones of a large whale were found near where the church stands, in marine sand twenty or thirty feet above the highest tides. M. Beetz showed me the tooth of a sperm whale that he had found as he stooped down to drink on the shore of a small lake fifty miles back in the bog.

So much for this subject of land-levels and salt marshes. It is a long digression but an interesting subject, and it occupied much of my thoughts as I walked along the shores of the Little Natashquan. My ears and eyes were open for the birds, however, and I heard and saw many, but none new or of special interest. The toads were still trilling their spring song this fifth day of July.

Arrived at the falls, I climbed to a high rock and sat down in the refreshing breeze relieved of the flies and mosquitoes. It is indeed a wild country. To the east stretched a flat coastal plain, as far as the eye could see clothed with 


\section{AMERICAN HARBOR, OR NATASHQUAN}

dark spruces and firs and terminated by a horizon of fog. To the north were bogs, rocky hummocks, small lakes and pools and patches of stunted forest, relieved here and there by ridges covered with white reindeer moss. Beyond lay the long low range of mountains which stretches all along the coast, the ancient Laurentian Mountains, the true "Everlasting Hills." The roar of the falls borne to my ears with varying intensity by the blasts of wind, the complaining notes of great black-backed gulls soaring overhead, served but to intensify the wildness of the scene. At my feet the red granitic rock was almost concealed by lichens, black, white, green, yellow, and gray, that are slowly disintegrating the hard surface and rendering it fit for more highly organized plantlife that is to follow. Around me were tufts of cotton-grass, mats of curlew-berry, mountain cranberry, low spreading pale laurel, firs, spruces, birches, and larches, all prostrate. Where the trees had tried to rise a few inches, they were blasted by the storms and their twisted and distorted branches stood naked to the air.

To the south, smiling in the sunlight, lay 


\section{IN AUDUBON'S LABRADOR}

the little town of Natashquan. The church and presbytery, in the thicket of white spruces, with the long straight walk through the trees on a raised sand-beach, the bridge newly built over the river, the few scattered houses of the inhabitants, the low, rocky islands, the blue water, the fleet of little fishing-vessels - all of these formed for me a familiar picture.

We expected to be off early on the 6 th, but were delayed by an easterly storm. The steamship Laurentian, Captain Boucher, - my old friend of the steamship Natashquan, - had come in with difficulty the night previous and had remained most of the day before venturing forth. The old steamer Natashquan, of La Ligne Internationale, that used to ply along this coast has gone to her last berth. Three times I risked my life by taking passage on her, yet I look upon her demise with fond regrets. She reminded me of the Bridget, in Van Dyke's poem "Gran' Boule," that ran "clear down to the Esquimault Point and back," -

" 'Dose engine one leetl' bit cranky, - too ole, you see, She roll and peetch in de wave. But I lak 'er pretty well;'" - 


\section{AMERICAN HARBOR, OR NATASHQUAN}

and I suspect that he wrote the poem after a trip in the Natashquan. It was an open secret that parts of her engine were wired together, that her iron shell was so old and weak that cement had been poured in to strengthen her feeble frame, and that insurance companies had long refused to carry her on their books. On the latter account, if for no other reason, Captain Boucher navigated with great caution, avoided the paths of other steamers, and, in thick weather, anchored at night. In lowlying fogs by day he himself climbed to the masthead and eagerly peered over the mists. I retain a vivid picture of the little captain in carpet-slippers holding to the rigging with one hand, a chart in the other, while he delivered from time to time his clear-cut orders in French.

On the Natashquan one could forage in the pantry and always find hot café-au-lait; but I especially enjoyed a luxury which was shared by only one other passenger, a pet beaver. This was a bathtub from whose tap flowed only the cold salt water of the Gulf. Each of us took a plunge in it daily and we never had to wait for any one else. 


\section{IN AUDUBON'S LABRADOR}

There was still plenty to see at Natashquan, however, and I took a long walk, chiefly in stunted spruces and in the bog - the barrens or tundras of Labrador - which occupies so much of the country in the sub-Arctic and Arctic zones. Audubon says in his Journal: "To tread over the spongy moss of Labrador is a task beyond conception until tried; at every step the foot sinks in a deep, soft cushion which closes over it, and it requires a good deal of exertion to pull it up again. Where this moss happens to be over a marsh, then you sink a couple of feet deep every step you take; to reach bare rock is delightful, and quite a relief." In another place he says: "We crossed a savannah of many miles in extent; in many places the soil seemed to wave under us, and we expected at each step to go through the superficial moss carpet up to our middles in the mire; so wet and so spongy was it that I think I never labored so hard in a walk of the same extent." These descriptions are very accurate. I should compare the labor to that of walking in deep wet snow. I took the temperature in the shade of an island of scrubby spruce in one of these extensive tundras, and 


\section{AMERICAN HARBOR, OR NATASHQUAN}

although my own feelings and amount of perspiration suggested at least $80^{\circ}$, I found it to be only $5^{8^{\circ}}$. In walking over the wetter part of these plains one chooses with care the more solid-looking places. I have often been reminded of the juvenile sport of "running tittledies" over weak ice. One of Audubon's young men was once mired to his armpits and had to be pulled out, but he must have been careless or perhaps over-venturesome in retrieving a bird. Using due care and sufficient agility one need have no fear of trouble in these bogs.

"Heavy the way over Gangle bogs, God keep him who has to tread it!"

The vegetation of the bogs consists in large part of sphagnum and other mosses, of reindeer lichen, cotton-grass, sundew, pitcher-plant, bake-apple, pale laurel, Labrador-tea, sweetgale, leatherleaf, and dwarf black spruces, firs, and larches.

As I had promised to collect spiders for my friend Mr. J. H. Emerton, an authority in that branch of natural history, I always went provided with bottles of alcohol. Spider-hunting in this region is rather trying work, for 


\section{IN AUDUBON'S LABRADOR}

near the ground one is simply overwhelmed with black flies. My gun is laid down, my glasses adjusted; then, at the critical moment when both hands are occupied with the bottle and the pursuit of the agile spider, my glasses fall from my nose, slippery with "fly-dope" and perspiration, and the flies become unendurable. Sometimes I spread a large bundle handkerchief on the ground and beat the spruce bushes so that the spiders fell on the handkerchief. A knowledge of the distribution of spiders helps to solve some unexpected problems, and the work was well worth while.

That afternoon I visited my friends Père Garnier and Père Gallix, and found them standing outside the church looking like a picture from Parkman. Dressed in their long black robes, each carrying a canoe-paddle and an axe, they looked as if they were about to plunge into the wilderness to convert the Indians. One of their axes was shaped like an Indian tomahawk, - a model that the Hudson's Bay Company has made for many years. Their mission, however, was merely a short trip up the Little Natashquan River in order to cut birch branches for the petits pois in their garden. 


\section{AMERICAN HARBOR, OR NATASHQUAN.}

I gladly accepted their invitation to go with them, and we three, with a great Dane dog; their faithful companion and beast of burden, were soon sailing and paddling up the river in a canoe. While they tied up their heads with great handkerchiefs to keep off the flies, and triced up their gowns to enter the scrubby forest to cut birch boughs, I took a bath at their favorite bathing-place of smooth rocks. On the way back we inspected a small potatofield they had made with infinite care on the other side of the river, as well as an area they had fertilized and seeded to grass, which they afterwards intended to cut for their cow.

Their garden near the church was surrounded by a neat fence of small spruce sticks, and contained spinach, peas, cress, beets, turnips, parsnips, dock, chives, rhubarb, and potatoes, the last-named just peeping above the ground, but favored in these regions by a freedom from potato-beetles. Their henhouse was planned and built by themselves with the utmost neatness and care. They formerly owned a horse, the first and last ever seen in Natashquan. It was old when it came here thirteen or fourteen years ago, and was care- 


\section{IN AUDUBON'S LABRADOR}

fully tended by the priests, who respected its infirmities, used it occasionally in farming operations, and, in a springless wagon, on rare occasions made the journey with it of five miles to the post at the mouth of the Great Natashquan River. At last it became too infirm to work, and for several years it was maintained in idleness by the bounty of the Church until its demise, when its body served as food for M. Beetz's foxes.

Supper at the Presbytery was a very pleasant affair from all points of view. I learned much of the history of the little hamlet. There was a trading-post on the farther side of the big river for many years, but it was moved to the right bank of the river in 1858. The first settler at American Harbor was Paul Vignot, an Acadian who came here from the Magdalens in I855. His two sons, Alfred and Charles, still live here. I have met them both. The church was built in I860. About forty years ago the name American Harbor was dropped and the term Natashquan, or Nataskouan as it used to be spelled, was retained. Our conversation ranged from the history of the place and the prospects of the people to Kant, evo- 


\section{AMERICAN HARBOR, OR NATASHQUAN}

lution, and the war. My friends felt that as a result of this horrible war there would be a great spiritual awakening and that they could freely return to France.

They are fine men, these priests. They belong to the Eudist Brotherhood, founded by Jean Eudes, and, with the expulsion of religious orders from France in 1903, they came to this country and took charge of the missions along the Canadian Labrador coast. Their bishop, Monseigneur Blanche, whom I had the great pleasure of meeting in I9I2, bears the title of "Évêque titulaire de Sicca, Vicaire apostolique du Golf Saint-Laurent." 


\section{CHAPTER IV}

GRAND ROMAINE AND OLD ROMAINE

N July 7 we were at last favored with a fair wind, and at 3 A.M. set sail in the Sea Star to explore the coast before us.

"Embark with me, while I new tracts explore, With flying sails and breezes from the shore.

But steer my vessel with a steady hand, And coast along the shore in sight of land."

The Sea Star was much smaller than its distinguished predecessor, the Ripley, for she was but seventeen tons burden and forty feet long, while Audubon's vessel was one hundred and six tons burden and probably over a hundred feet long. The Ripley was what is called a topsail schooner with yards and square topsails. The Sea Star, when carrying full sail, had, besides her main and fore sails, a jib and flying jib, gaff topsail and main staysail. She was painted green with white trimmings. The cabin was six by eight feet, and high enough to permit a man to stand erect. It contained two bunks so closed in that the apertures 
GRAND ROMAINE AND OLD ROMAINE

through which the occupant had to struggle in and out were only forty-one by sixteen inches, - a state of affairs which suggested partial asphyxiation and a coffin. A sea-chest and a small iron stove occupied much of the floor space, while shelves, cupboards, hanging lamps, clothes, guns, and other paraphernalia filled in all available spaces. Forward two men slept in the galley, where the cooking was done and where we ate our meals. A large shelf near the stove was given up to me for my boxes of bird-skins, which here dried well. Many of Audubon's were ruined by the damp. The hold behind the galley contained things innumerable, and here, out of the wind, often with the hatch down, the botanist arranged his specimens and kept his presses and trunks. The deck, not taken up by galley and cabinhouse, was fairly filled with water-tanks, spare rigging, driftwood to be cut up for the stove, and, during pleasant weather, by the bulky drying-cases of the botanist. On the starboard side of the deck forward, balsam boughs were spread, and here we arranged sleeping-bags at night. My home-made sleeping-bag proved very satisfactory. The outer bag was made of 


\section{IN AUDUBON'S LABRADOR}

balloon silk, its waterproof qualities improved by a filler, with the addition of a little oil paint; a flap extended over my head in the baker-tent fashion, held in place by small guyropes; cheese-cloth hung from the borders to keep out insects. It is true that I found one morning a dozen aldermanic-looking mosquitoes inside the canopy, but as a rule they were kept outside. The inner bag was made of lamb's-wool wadding with a covering of gray flannel and a lining of sateen. The outer bag weighed two and a half pounds, the inner, three and a half pounds, and both could be compressed into so small a space as to occupy less than half of a rucksack. As compared with the ordinary bulky and heavy sleeping-bag it was certainly preferable, but in heavy rainstorms we were driven to the shelter of the cabin.

There was no bathtub on board, but what could be finer than a plunge overboard or a pail of sea-water poured on head and shoulders by one of the men, who shuddered with horror at our extraordinary temerity. These two men were fine fellows. Guillaume (pronounced Eel-yam), with buff-colored shirt with green 




THE SEA STAR

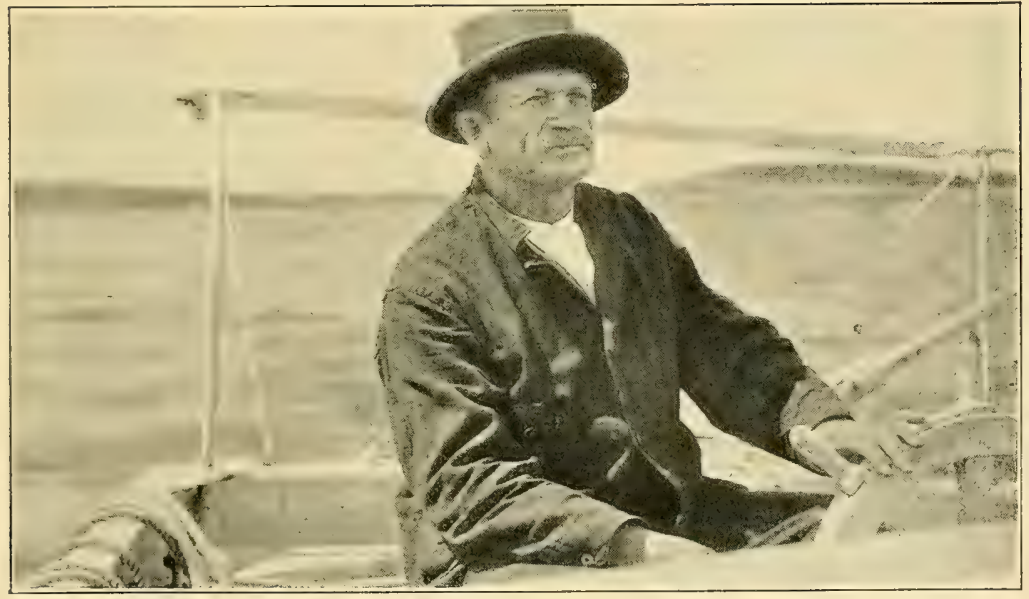

CAPTAIN A. EDMOND JONCAS 

GRAND ROMAINE AND OLD ROMAINE

trimmings, a cocked hat, and drooping mustaches, was familiarly known by us as the Pirate. He was always longing to shoot something and had to be restrained; yet he had a pleasant voice and a habit of singing softly to himself old French songs. The cook, Ernest by name, wore a pale pea-green shirt and had most obliging ways. $\mathrm{He}$ was a man-of-allwork, ready at any moment, day or night, and above all an excellent cook. His bread was of the best, his pancakes - crêpes - of the lightest, and the very thought of his patties and confitures makes my mouth water. The captain remarked that whenever Ernest was up to his elbows in bread-making he was sure to be needed on deck to shift sail. It was hard luck for Ernest, but he always took it as a joke, and I never noticed any ill results in the bread.

Of the captain, A. Edmond Joncas, I speak in terms of the highest respect. It grieves me to think that Audubon, that great and good man, should have had his Labrador trip so nearly spoiled by the "ass of a pilot" when he should have had a man like our captain. The Joncas family came from La Gascogne, France, to the New World in I699, and settled at St. 


\section{IN AUDUBON'S LABRADOR}

Thomas near Quebec, but the men have always followed the sea. One of the captain's earliest recollections is of a trip at the age of five along the Labrador coast in his father's trading-schooner. At Natashquan dogs were hitched to a komatic for his benefit, and he enjoyed dog-sledging over the moss in summer. At the age of twenty-one he sailed before the mast to India, and since he was twenty-three he has commanded a schooner on the Canadian Labrador coast. He therefore knows this coast most intimately, - every nook and corner, every island and reef, in a way that no chart reveals. The best chart is misleading, for islands half a mile long, not to speak of rocks and reefs, are often entirely omitted. In fact all modern charts are based on the survey made by Captain Bayfield, of the Gulnare, who was at work on the coast in Audubon's day. Although fairly accurate, these charts give but an imperfect idea of the number and size of the islands and of the intricacies of the coast. The maps recently published by the Department of Lands and Forests of Quebec, which, however, do not attempt to give the depths of the water as do charts for navigators, are a lit- 
tle more satisfactory. The captain, however, never used a chart in navigating these waters, as his knowledge, supplemented occasionally by the use of the lead, was so much more valuable. I once measured the first fathom of the captain's plumb-line, and found it to be ten instead of six feet long, and I noticed that the cautious William would sing out "Trois bras" whenever this line indicated three and a half and even four fathoms. When one considers that there are probably two thousand islands on this strip of Audubon's Labrador, it is evident that a pilot with a congenital and instinctive knowledge of the coast is highly desirable.

Not only was our captain familiar with the topography, but he was also familiar with the human population of the coast, - he knew every one by name and their fathers and mothers before them. He said it was not uncommon for a man to come out to his schooner in order to learn from the captain his own age. All the names of Labradorians mentioned by Audubon in his Journal were familiar to the captain. The descendants of most of them were still living on the coast. He 


\section{IN AUDUBON'S LABRADOR}

read the Journal, which I had brought with me, with the greatest of interest, and was able from the descriptions to identify the harbors where the Ripley cast anchor.

The captain was also familiar with the seabird population and was able to take me to interesting ornithological regions. With all this he had a pleasing personality, one which at once inspired confidence and affection. I was indeed fortunate in my pilot - far more fortunate than Audubon.

We had a long course ahead of us, over thirty miles unprotected by islands from the sweep of the Gulf, the longest unprotected strip along the whole Canadian Labrador coast east of Mingan. Five miles brought us to the Great Natashquan River, which has two mouths separated by a large island; the eastern mouth is much larger than the western, with which I was well acquainted. Both pour great volumes of dark-brown water far out into the sea, whose color, deep green, forms with the river water a great contrast. At English Point, a short way beyond the western mouth, is a lighthouse recently built. It is the only one between St. Mary's Island on the east and the 
Perroquets on the west. We sailed by a long stretch of sandy shore, backed here and there with a strip of pale-green beachgrass on sandy dunes. Back of that was the dark spruce forest. In places the sand-banks were cut away in cliffs. The low range of mountains was so distant at this point that we could see only the highest peaks. It was a desolate shore, harborless and unprotected, low and uninteresting. From the deck of our little schooner it was every now and then entirely swallowed up as we descended into the hollow of the waves.

Twenty-two miles from Natashquan we passed Kegashka, a small hamlet of three or four houses at the mouth of the river of that name. Here is a good harbor "secure against the thirty-two winds indicated on the compass" according to the Abbe Huard, ${ }^{1}$ but difficult to enter. It was to this place in 1854 , a year before the settlement of Natashquan, that the first group of Acadians came from the Magdalens. I do not admire their choice. The principal man there now is Jim Forman, salmon-fisher.

${ }^{1}$ Labrador et Anticosti, par 1'Abbé V.-A. Huard, A.M. (Montreal et Paris, 1897.) 


\section{IN AUDUBON'S LABRADOR}

Rocky points now began to appear along the shore, gray and red granitic rocks, ribs from the backbone of the Labrador Peninsula. Against these the waves sent up great masses of white spray. Twelve miles farther west is Musquarro. Here are a small Indian mission church and one or two houses. In June this is the great gathering-point of the Montagnais Indians for their annual religious rites, and a priest comes there to meet them; in I909 I had seen the Indians leaving Natashquan for this purpose. Gradually the land behind became higher and low islands appeared. At Washsheecootai there is one house on the point, that of a salmon-fisherman, the fatherin-law of our cook. Here is where Ernest had come a-courting.

About fifty miles from Natashquan we anchored in a protected cove of Triple Island, but alas! only a few herring and great blackbacked gulls and fewer razor-billed auks were to be seen. The gulls flew complainingly overhead, and well they might, for their nests, scattered over the island, had all been robbed. This can easily be explained, for it is only nine miles from here to the mouth of the Romaine 
River, where there are white fishermen, an Indian village, and a Hudson's Bay Company's post. The river is called the Grand Romaine to distinguish it from the other Romaine River to the westward of Esquimaux Point. It is said that the derivation of Romaine is from the Montagnais orumen, or olumenne, which means red earth, and at both of the Romaine rivers there is yellow and reddish clay which, when boiled in oil, is used for paint. L'orumen or l'eau Romane easily became Romaine, and this seems a reasonable derivation for a word which appears at first sight to be out of place in this cold and barren region. The Post here is presided over by a son of my old friend Monsieur Molony, the salmon-fisherman of Mingan.

We at once visited the Indian encampment. Nearly all the people retreated to their tents, but by a judicious presentation of plug tobacco, with which I had provided myself, I induced a number to come out and be photographed. The innumerable Indian dogs seized the occasion to indulge in a general fight, when nothing could be seen but a confused mass of feet and tails. All the tents of the interiors of which I had glimpses were very neat; the floors 


\section{IN AUDUBON'S LABRADOR}

were of carefully thatched fresh balsam boughs; guns and various household goods were neatly arranged at the sides. Each tent contained a small sheet-iron stove whose smoke-pipe was conducted out through the top. In one tent was a small sewing-machine. We had been told by Richard Joncas, of Natashquan, of one Indian who spent all his fortune on a parlor organ and another one who indulged in a safety razor.

One family group inside a tent struck me as being particularly picturesque, but even the tobacco did not bring them out. In despair I seized each one in turn by the hand and led them forth amidst much laughter and grouped them about a pot on a fire for their photograph. The girls, who were smoking their pipes, for both sexes and all ages smoke, - could not, however, be induced to continue the process during the picture-taking. One of the men, - particularly well built, tall and lithe, with a face indicative of much intelligence and strength of character, - I learned through our interpreter was Pierre Lolo, the best hunter of the tribe.

Of late the Indians have been fishing for cod 84 
for commercial purposes. On the morning that we sailed for Romaine, we passed a half-dozen small fishing-schooners or barges, manned entirely by Indians, all engaged in fishing. We heard that they were extremely expert in this, but suffered greatly from the wet and cold, as they possessed no oilskin clothing. A Labradorian told us that one Indian could catch as many fish as two whites.

Fish spread to dry are not safe anywhere in the neighborhood of Indian dogs, so the smoothly rounded rocky islands that make the harbor were utilized for this purpose. Morning and evening a picturesque company of white men and women could be seen spreading or stacking the harvest. Like the Indians, the people of the coast are fond of bright colors, and one often sees purple or green or red waists or sweaters. I was particularly attracted by a pale salmon-colored waist worn by a woman in a big apron, the "header" at a splitting-table. The houses, too, are painted in blues and yellows and pinks.

The next day we rowed and sailed to the rapids at the mouth of the Romaine River. Splendid salmon were jumping completely 


\section{IN AUDUBON'S LABRADOR}

out of the water, but no artificial flies were cast for their delectation. The owner of the river, Sir Charles Ross, was busy in Quebec making rifles for his country.

The botanist always carried a large tin collecting-box painted white so as not to absorb the sun's rays. Its color made it conspicuous at a distance and its weight and bulkiness prevented him from carrying the rucksack containing the frying-pan and provisions, which, naturally, fell to my lot. We always separated early in the day on our two different quests, with the understanding that we should meet at dinner-time on some designated rocky peak where we hoped to get out of the flies. The arrangement was a very good one for me; I did not need to worry - it was the other man's interest to find me. He found me that day as on all others.

I was particularly struck that day with the unsuspicious nature of Wilson's warbler that bright-yellow bird with a glossy black cap. I sat down in a thicket where two anxious parents, each with its bill full of insects, scolded me with loud chips. They were often within five or six feet of me, and one of them nearly 


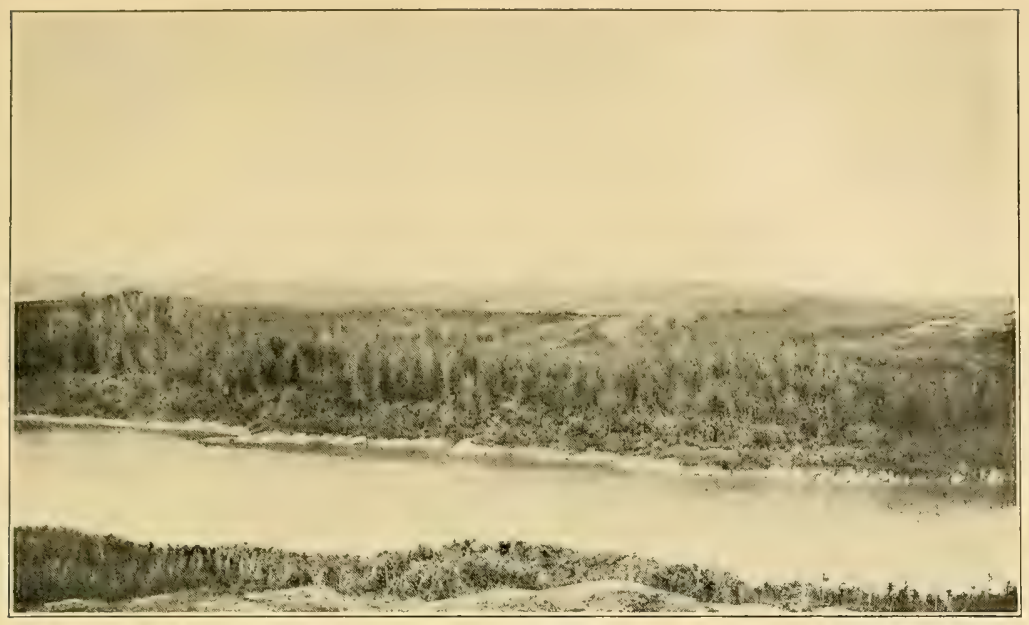

LOOKING NORTH OVER GRAND ROMAINE RIVER NEAR ITS MOUTH

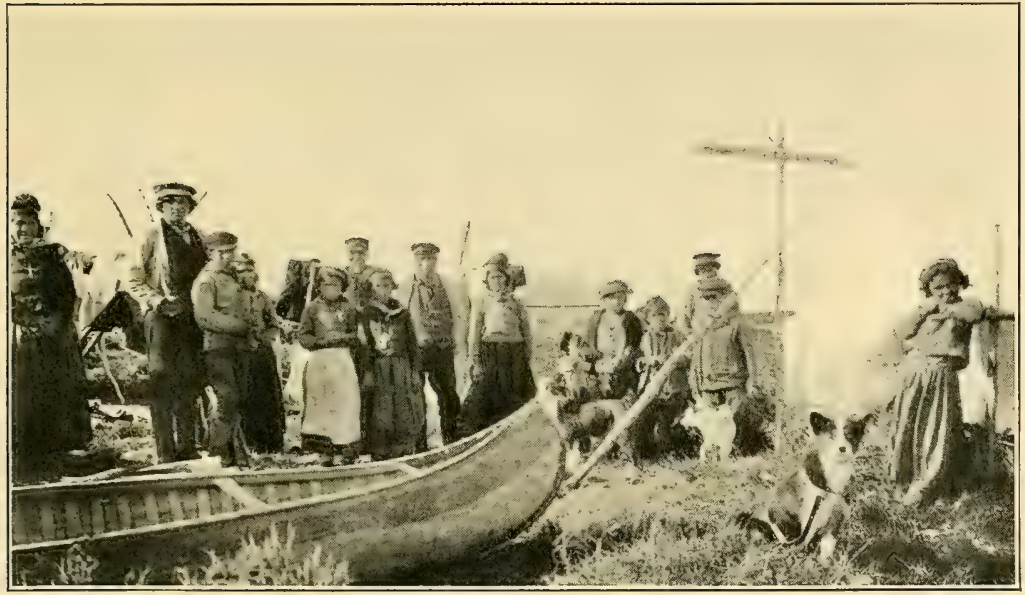

INDIANS AT ROMAINE 

alighted on my leg stretched on a log. It was evident that a nest of young was concealed near at hand. It is a common bird all along this southern coast.

It might be objected that a bird could not chip with "its bill full of insects." Birds are, however, not only able to chip and scold in the most lively manner, but even to sing with their bills overflowing with insects. This is because the bird's voice is produced lower down, in the syrinx, which corresponds to our larynx, and the mouth and tongue are not needed for vocal expression. In all but a few recent pictures of a bird singing, the tongue is shown as if it were used as is the human tongue in song. As a matter of fact, the bird's tongue during song lies passive out of sight on the floor of the mouth.

The view over the valley of the Romaine River, with its thickly crowded spruce forests, to the barrens dotted with lakes and lakelets beyond and to the distant range of low mountains, was a characteristic one of this region. In the bogs a hard surface of ice could be found a foot to eighteen inches down, and on a sand-ridge the ground was frozen solidly 


\section{IN AUDUBON'S LABRADOR}

thirteen inches from the surface. These sandridges were exactly like the ridges paralleling the beach at Natashquan, and, although now several miles back from the coast and fifty or a hundred feet above it, they were once at sealevel and point to the elevation that is in progress on this coast.

In one of the small ponds, with steep, overhanging sides of matted sphagnum, laurel, and spruce, I came upon a mother whistler or golden-eye duck with a brood of ten young, which, with their black caps and white cheeks, looked for all the world like great chickadees that had taken to the water. The mother held her head erect as she swam back and forth, and all her movements betokened anxiety in the presence of man. The young swam dutifully after her in a compact bunch and showed no fear.

In a sheltered valley where the trees were twenty feet or so in height a pigeon hawk launched himself at me quivering his wings and crying with anger. His assault was at once followed up by the assault of a slightly larger bird, the female, and as long as I remained in the vicinity, they continued to scold 


\section{GRAND ROMAINE AND OLD ROMAINE}

and attack me, coming sometimes within fifteen or twenty feet of my head. Search as I would, however, I could not find the nest, although I must have been as hot on the trail as I felt.

The next day was dark and easterly with occasional rains, but we put to sea, and passed an island that abounded in razor-billed auks, eiders, and gulls, with here and there a puffin and a murre. Some of these murres - very properly known in England as foolish guillemots - nearly hit our sails as they flew by the boat. On another island lived a family of fishermen, natives of Anticosti, who would not obey Menier's hunting-laws and had been deported.

We took refuge from the coming storm in the harbor of Old Romaine, where there was formerly a Hudson's Bay post, but now no sign of human occupancy is to be discerned. It is a well-protected basin perhaps a mile long and a quarter of a mile broad, hemmed in by numerous low rocky islands.

It may have been here that Audubon landed, for the distance from Natashquan would indicate this region: "June 29. At three this 


\section{IN AUDUBON'S LABRADOR}

morning we were off the land about fifteen miles, and about fifty from American Harbor. ... We neared the shore, but as before our would-be pilot could not recognize the land, and our captain had to search for a harbor where we now are, himself. We passed near an island covered with Foolish Guillemots, and came to, for the purpose of landing; we did so through a heavy surf, and found two eggers just landed, and running over the rocks for eggs." The Ripley apparently did not stay there, but went on to Wapitagun. The distance given by Audubon of that anchorage from Little Mecattina, forty-three miles, and the description of the country, identify Wapitagun, which indeed he mentions by name in his account of the razor-billed auk.

When we were anchored we explored the land and found it to be a wild, desolate country of bog and pool. The forest had retired inland; only patches of stunted spruce and fir and larch were to be seen, yet in one of them a Maryland yellow-throat was singing his "witchery" song as much at home as if he were in New England. It is my most arctic record for this bird. The Arctic Zone begins as a narrow 


\section{GRAND ROMAINE AND OLD ROMAINE}

strip at Natashquan; here it had developed broader proportions and its character was unmistakable. It included, however, low thickets, - Hudsonian islands, - and it was in one of these that the yellow-throat was singing. With it were tree sparrows, true residents of the Hudsonian Zone. This is the little sparrow with the chestnut-colored top-piece and the one dark spot on its breast that is to be found only in winter in New England.

The horned lark, a bird characteristic of the Arctic fauna, was nesting close to the shore; its golden speckled young of the first brood were on the wing, and the old birds were indulging in true "sky-larking" or singing up in the sky. It was interesting to watch the determined manner in which the bird would push its way upwards, sometimes nearly vertically, sometimes in irregular circles. It was all done so silently that one almost held one's breath in order to hear the outburst of song which was sure to come as soon as the lark had reached a height of six or seven hundred feet. Here he appeared as but a minute speck in the sky. The song during the first excitement was often continuous for several moments, but 


\section{IN AUDUBON'S LABRADOR}

later it came in regular beats while the bird soared in circles or headed into the wind. It was interrupted while he flapped his wings and got his breath. It was a squeaky, jingly, metallic song, abounding in high notes and fine trills, not a very polished musical performance, but sufficiently pleasing and decidedly interesting. Often it was impossible to find the bird from whom came the tinkling shower of melody, and one would catch sight of it only as it came plunging headlong to earth as silent as it rose. In fogs it was always a case of "vox, et prceterea nihil."

In I909 Mr. Bent and I had found a breeding pair of horned larks at Natashquan, but it is doubtful if they breed regularly to the westward of this. The prairie horned lark breeds about Quebec, but how far beyond the Saguenay to the eastward it extends its range I do not know. There is a long forested shore between the Saguenay and Natashquan, and it is unlikely that horned larks breed regularly in this intervening space.

The botanist was in his element, but rather low in his mind on account of the embarras des richesses. He had not let the grass grow under 
GRAND ROMAINE AND OLD ROMAINE

his feet, for he generally uprooted it with his little pick and packed it away in his white tin box, and later washed it and put it in his presses. But his presses were all full, for drying plants in this damp climate is a difficult matter, although he used corrugated boards for ventilation and flaked naphthalin as a preservative and dryer. Artificial desiccation by means of a kerosene stove he found was out of the question in our crowded quarters. We did not wish to be burned or blown up.

We seemed to be having genuine Audubonian Labrador weather, for in the afternoon it came on to blow hard from the east and the air was filled with driving rain. Our little harbor was white with spindrift blown horizontally by the wind and dashed up against the rocks, which looked as if they were covered with drifting snow. The great black-backed gulls with wings partly closed sailed into the blasts borne on the currents deflected from the rocks, and, with superb mastery of the air, whirled and pirouetted as if in sheer delight. This was on July 9, I915. On July Io, I833, Audubon experienced a similar gale and he describes it vividly. "The rain," he writes, "is driven in 


\section{IN AUDUBON'S LABRADOR}

sheets which seem scarcely to fall on sea or land; I can hardly call it rain, it is rather a mass of water, so thick that all objects at any distance from us are lost to sight every three or four minutes, and the waters come up and beat about us in our rock-bound harbor as a newly caged bird does against its imprisoning walls. The Great Black-backed Gull alone is seen floating through the storm, screaming loudly and mournfully as it seeks its prey; not another bird is to be seen abroad."

It was a wild lullaby that night. The rain dashed in sheets against our little craft, which rolled and pitched and tugged desperately at her rattling chains. The wind howled through the rigging as gust after gust tore by. The halyards slatted against the masts in a loud rub-a-dub-dub, and the roar of the surf on the rocks and the hissing of the rain on the waves formed a continuous undertone. I turned into my bunk in the cabin early, having perfect confidence in the captain and in the fact that we had two anchors out in five fathoms of water on a sand and clay bottom. I slept through it all, perhaps for the same reason that the assistant of the Bishop of Newfound- 




SURF ON HARBOR ISLAND, OLD ROMAINE

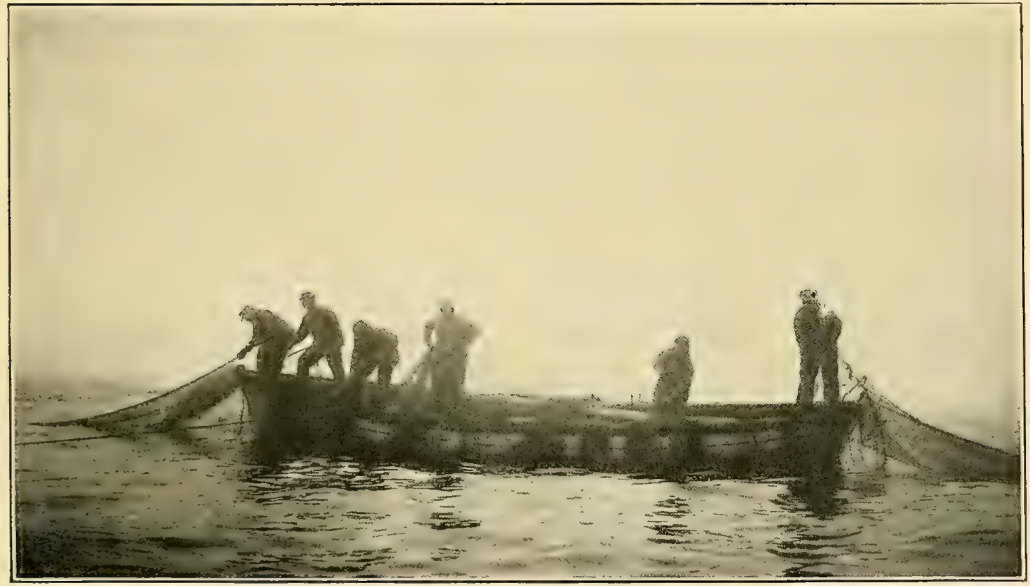

HAULING A COD-TRAP 



\section{GRAND ROMAINE AND OLD ROMAINE}

land slept during a similar storm. The aged bishop was on a tour of the outlying island posts in the Church of England yacht, and was unable to sleep when they were storm-tossed. He watched the night out in the cabin, but the assistant slept calmly. Finally, in the fiercest of the blow, the bishop could stand it no longer, and, rousing the vicar, said, "How can you sleep in a storm like this?" To which the younger man replied, "An easy conscience, my lord."

Captain Joncas was up several times in the night to let out more chains and fasten them to the masts with ropes, for the constant strain had broken the windlass. I had rather scoffed at Audubon's gales and hurricanes and thought they were merely a landsman's description of stiff breezes, but if he had anything like our gale, he certainly employed the proper terms. It is unusual even in Labrador to have such a storm in July. On the following day we visited the large harbor island, and watched the surf which was dashing upon the rocks and filling with foam the entrance through which we had come.

The next day, and again the next, we en- 


\section{IN AUDUBON'S LABRADOR}

deavored to sail out, but calms, head winds, and heavy seas compelled a resort to sweeps and to towing in the small boat to keep us off the dangerous reefs and bring us back safely to our haven. Our time was not wasted, as both of us were adding to our knowledge of the fauna and flora. (Mr. Dooley said that he should think the wife of a certain explorer would be jealous, as her husband was continually talking of Fauna and Flora.) If the delay continued much longer we decided to change the name of the harbor from Romaine to Remain. It was one of the occasions when a gasoline motor would have been useful, but I am very glad we were able to accomplish the trip without this unpoetic adjunct.

The great black-backed gull, which is an abundant breeder all along the coast, is my ideal of a noble-looking bird. It is true that it is a pirate of the worst sort, and takes every opportunity to eat the eggs of terns, eiders, and other water-birds and even to kill and eat the young. On one occasion I saw a gull swoop at a family of eider ducklings, which promptly dived and escaped. On another occasion a gull pounced on a young eider and seized it in its bill, 


\section{GRAND ROMAINE AND OLD ROMAINE}

notwithstanding the protests of the mother, who made a great turmoil on the water, flapping about like a wounded bird. The pirate bore the soft, downy thing to the rocks, and, as we sailed by, we could see it pounding its little life out and devouring it. M. Beetz has seen this gull drop a young duck from a height on the rocks to kill it, and quickly fly down to pick up the tender morsel in the same way that it drops clams and sea-urchins to break their shells. The captain said that the people here thought this habit of preying on eggs and young of other birds was a recently acquired trait because "bait," small fish, were scarce, but Audubon in his Journal says, "The $L$. marinus is extremely abundant here; they are forever harassing every other bird, sucking their eggs and devouring their young"; and again, "The Larus marinus was observed trying to catch the young of the Eiders."

As with some other pirates and highwaymen, the home life of this gull is, however, of the best, and I watched with great pleasure two pairs of these birds on different parts of the island close to our anchorage, which were all devotion. They learned that we did not intend 


\section{IN AUDUBON'S LABRADOR}

to harm their young after a trying experience on the first day when I put aluminum bands on the legs of these same youngsters. During this process the parents launched themselves at me, screaming violently, and forgot their usual timidity by approaching within half a gunshot. Morning and evening and at various times through the day the slightly larger male and the smaller female of each pair could be seen standing side by side, looking affectionately at each other from time to time, and glancing proudly about at their offspring, which were crouching flat on the rocks or in the moss waiting until their last meal should be so far absorbed that nature demanded more. The splendid snow-white heads, breasts, and tails of the old birds contrasted strikingly with their broad blue-black backs and wings. Pairs of these birds in the same attitude were common sights all along this Labrador coast, and they rose up with their threatening screams whenever we landed. Their nests were often on the highest points, sometimes great shallow saucer-shaped depressions in the moss and turf, sometimes built elaborately with grass stalks, small sticks, feathers, and dry seaweed. 




GREAT BLACK-BACKED GULLS

Photograph by Howard $\mathrm{H}$. Cleaves

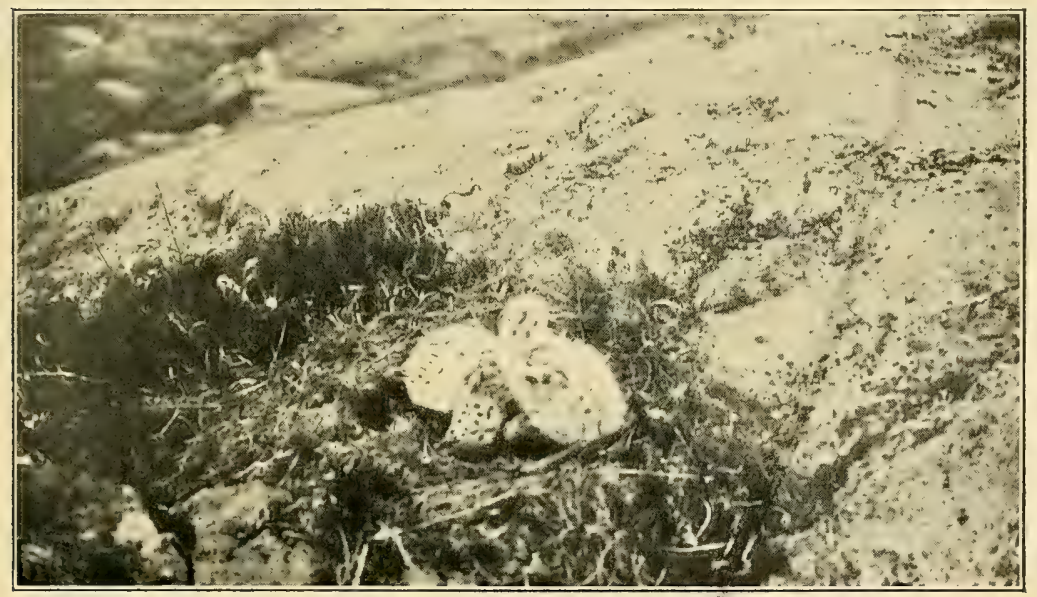

YOUNG GREAT BLACK-BACKED GULLS 

The eggs, generally three in number, are splendid great brown-speckled things. The gray and spotted downy chicks soon leave the nest, and, spreading out flat and motionless, are difficult to see on the granitic lichen-covered rocks, with which they harmonize in a wonderful manner. When they are as large as fair-sized domestic fowls, they are considered great delicacies by the people, and the tender flesh is much sought. They take to the water before they can fly, and are skillful swimmers even at a very early age.

In walking alone over the bogs and hills even some miles inland I have often been startled by the very human quality of the calls of this bird, which vary from a harsh scream, or loud cow cow, to low conversational notes. Car-cas-sonne and au-par-a-vant are the most easily syllabized of their calls, and I have often fancied I heard them cry out help help in the most stilted manner of speech ever used by Irving. This appeal would sometimes be followed by the word ma-ma. Notwithstanding its highwayman traits I am fond of the great black-backed gull.

It might be well to relate here a sequel to 


\section{IN AUDUBON'S LABRADOR}

the banding incident related above. I had provided myself with a number of aluminum bands, each stamped with a number and " $\mathrm{No}$ tify Am. Museum. N.Y.," furnished by the American Bird-Banding Association, whose headquarters are at the American Museum of Natural History in New York City. Birds which are banded in the nest, and recorded on cards that are sent to the Association, may afterwards fall into the hands of man, and if the date and locality of their decease is forwarded to the central bureau where the original record is kept, many interesting and unexpected things may in time be learned about migration and bird wandering. Already considerable valuable information has been accumulated. Now it so happened that a couple of weeks after I had banded those downy black-backed gulls, Ambroise Lalo, a Montagnais Indian, was much surprised to find a little shining ring on the leg of a plump young gull that he was preparing for the pot, and he later presented this curious ring to Captain Joncas. In this way I learned that number 36,340 met his death only four miles from his birthplace.

I had an amusing experience here at Old 100 
Romaine, or rather an Indian had. I had shot a double-crested cormorant, which fell into a shallow passage between two islands. It was too interesting a specimen to lose and, wading nearly to my neck, I succeeded in recovering him. While I was about it I decided to cross the passage a short distance farther up and pick up a horned lark, that, with the usual hardihood and vigor of this species, had flown some distance after I had shot it before it fell. As I was creeping along a rock on my return, clad only in my binoculars and shotgun, I suddenly came upon an Indian in his canoe. The man paddled by with an imperturbable countenance, although he had probably never seen a white man under such peculiar circumstances, for, as far as my observation goes, neither white men nor Indians on this coast ever think of bathing in the sea.

: Indians were frequently seen cruising about and visiting the islands, shooting the nesting birds and taking the eggs and young. "You can't blame them," said our captain, the gamewarden; "they are starving." The winter hunt is growing poorer of late years and the fall in the price of furs since the war began has fur- 


\section{IN AUDUBON'S LABRADOR}

ther impoverished them. The great increase in the price of furs before the war induced many whites to enter the business of trapping, and thus help to exterminate the Indian's chief dependence. At Grand Romaine the Indians had no flour.

Our captain was a broad-minded man, and one who could rise above prejudices. No one on the coast would think of eating cormorants, although gulls, murres, and auks, which live on the same fishy food, are eagerly eaten. The uncanny, snakelike neck, the bare patch of orange-colored skin at the throat, and the curious web on the feet connecting all the toes, as well as the filthy nesting-habits, easily account for this prejudice. It is possible that the old Mosaic law forbidding its use as food may still have its influence. After preparing the skin of my cormorant, I broiled the breast and served it with a well-seasoned flour and onion sauce. The men turned away from it with horror, but the captain, much to his own surprise, found it delicious, as indeed it was, tender and agreeable, tasting not at all fishy. I trust I have not introduced a taste which will lead to the destruction of this interesting 


\section{GRAND ROMAINE AND OLD ROMAINE}

bird, but few are as broad-minded as our captain, so there is no need to worry. Unfortunately the bird has a very bad name, and is accused of eating young salmon, and the hand of every salmon-fisher is turned against it. Cormorants are shot as pests and fed to the dogs and to captive foxes. While we were detained at Old Romaine, companies of five to twenty or thirty of these weird-looking birds were frequently to be seen flying back and forth from the direction of Grand Romaine River, and the birds' case looked bad. The bird I shot was flying towards the river, and his stomach was filled with small fish, not salmon. It would have been interesting to investigate the stomach-contents of the returning birds, but that I was unable to do.

In the spring of I9I4 the attention of the Canadian Geological Survey was called to complaints of damage done by cormorants to the salmon-fisheries of the Gaspé coast, and the ornithologist, Mr. P. A. Taverner, was sent there to investigate. The club anglers of that coast were insistent that the cormorants were doing much damage among the young salmon. Mr. Taverner found, however, that 


\section{IN AUDUBON'S LABRADOR}

the cormorants rarely ascended the rivers beyond the tidal influence. Of thirty-two stomachs examined, fifteen contained sculpins; five, herrings; two, tom-cod; and one each, capelin and eels; the others were empty or the contents were unrecognizable. The birds with empty stomachs had been fishing where there were no sculpins. The number of salmon in the rivers has been increasing of late years, and with this there has been an increase in the number of cormorants. Mr. Taverner concludes, therefore, that the birds are not harmful to salmon, and that they may even be beneficial by weeding out the weak and unfit fish. A vigorous young salmon is so difficult to catch that the sluggish bottom-feeding sculpins are preferred. It is to be hoped that the clubs will withdraw their offer of twenty-five cents a head for cormorants.

To persuade the average man that any living species is worth preserving unless it has some obvious value to mankind is a difficult task. A friend of mine was watching the nest and eggs of a Virginia rail, until a barbarian in the form of a small boy found and deliberately destroyed them. When remonstrated 
with, the boy asked, with a finality not to be gainsaid, "What use are they?" Some workmen looking at a flock of beautiful gulls soaring with exquisite grace over the water were overheard to ask the same question: "What use are they?" Ornithologists and naturelovers are often hard put to it to give so-called practical value to certain birds, so that their lives as individuals and even as species may be safeguarded.

The æsthetic value of birds - the joy which their beauty and grace and their free and happy lives can give to the workers in this sordid world - does not appeal to the thoughtless. The naturalist's interest in any representative in the great evolutionary tree of life, and his sorrow at its extinction and the resulting disturbance of nature's balance, are entirely beyond the comprehension of the ordinary man. He is satisfied if any species can be shown to be of economic use, but in the absence of this dollars-and-cents value he cares not whether the species lives or dies. The cormorant is an example of a bird that appears to have no so-called use, and one against which, therefore, bad marks are only too will- 


\section{IN AUDUBON'S LABRADOR}

ingly placed. To the nature-lover from either the æsthetic or the scientific point of view no argument is necessary. The sight of a large flock of cormorants, swinging resistlessly by in steady flight along the New England coast some autumn day when the surf is pounding hard on the reefs and ledges, brings joy to many, and lifts them, for the time at least, above the thoughts of mere money-getting. That the cormorant was originally a land-bird and related to the American vultures becomes credible to the scientific nature-lover when he finds that it sometimes builds its bulky nest in a tree, that its young are slow in developing, and that it sits with its wings spread out. There is much to be learned and much to be enjoyed in the study and contemplation of this bird, and one cannot help feeling disturbed when wealthy salmon-anglers from the cities on insufficient evidence selfishly condemn it to possible extinction.

I hoped to get a taste of another unusual viand at Old Romaine, a viand which the captain especially praised and was eager to obtain, I refer to the porpoises which from time to time puffed and rolled through our harbor, - 


\section{GRAND ROMAINE AND OLD ROMAINE}

but the hunters were unsuccessful after several attempts. The men called them pussies, or so the word sounded to us, and it was adopted for the rest of the voyage. The Acadian word for porpoise I have since found to be poursille.

Small flocks of Hudsonian curlews occasionally flew by us from west to east while we were at this anchorage. They were on their southern migration, and are always early migrants. Their long, curved bills and loud calls easily identified them. It is probable that they cross the base of the peninsula from James Bay, follow the coast as far as Chateau, cross over to Newfoundland, and so on down the eastern coast of the continent. They are considerably larger than the Eskimo curlews that formerly existed in countless multitudes, but are now nearly extinct.

Another sea-bird worth mentioning is the Caspian tern, of which I saw five or six at Old Romaine. It is a fine bird, resembling in plumage and habits the common tern, but nearly as large as a herring gull. Its brightred bill, its large size combined with its habit of flying with the bill pointed downwards, and its method of capturing fish by a plunge from 


\section{IN AUDUBON'S LABRADOR}

a height in the air at once serve to identify the bird here. Its voice is a harsh, unpleasant scream entirely unlike any of the sounds made by either common tern or herring gull. I was sitting on the rocks of our harbor one afternoon when I was startled by the scream of this bird and saw one chasing another. Later one of them darted at a great black-backed gull and then launched itself at the water for a fish. Audubon saw several pairs of this remarkable bird in Labrador, but he confused it with the Cayenne or royal tern, a bird of much more southern distribution. Frazar also found it there in I884, and Mr. Bent and I saw one at the mouth of the Natashquan River on May 3I, r909. Captain Joncas recognized the bird as la grande estorlette, and hoped to show us its breeding-ground, but in this, to my regret, he was unsuccessful. It was a good bird to see and record, however. Long may it live and multiply in Labrador!

Another interesting ornithological experience at Old Romaine was with a family of spotted sandpipers, the familiar teeter-peep of the New England coast, - l'alouette a branle queue the captain called it. At the mouth 108 


\section{GRAND ROMAINE AND OLD ROMATNE}

of a little stream an anxious parent nervously flew about or walked and teetered on the rocks where I landed. Soon her alarm increased and she fluttered within a few feet of me, endeavoring to lead me away from her little family of three or four downy chicks that were crouched concealed in the grass. Concealment proving of no avail, they proceeded to run away, wagging the posterior parts of their bodies - their tailless tails - like adults. Coming to a pool of water, they swam with ease and grace, sitting erect like little ducks. Later in the trip, at Blanc Sablon, I came on another family of young of this species, nearly all full-grown, but still unable to fly. I caught one and put it in the river, where it at once dived and swam under water, using its wings and feet for propulsion. After a short subaqueous flight it rose to the surface, quickly swam to the other side, and walked out on the sand where its anxious mother was awaiting it. It is evident that shorebirds are of water ancestry, and, like the auks with which they are related, they swim and dive before they can fly. The partially webbed feet of some species also show this water ancestry. 


\section{CHAPTER V}

\section{WAPITAGUN}

A $T$ last the wind changed to the southwest, 11 the sea fell noticeably, - "As winds forsaking seas more softly blow," - and after a brief and mosquito-filled night we were safely off at three on the morning of July I4. That was an eventful day, packed full with interesting experiences. The wind compelled us to sail offshore - au large - instead of threading some delightful inland waterways of which the captain had told us. The sun rose clear and cold over a shore that, as we advanced, grew higher and more bold in rocky headlands. It was a great pleasure to feel the gentle land breeze after so long a period of raw sea-winds. As we joyously bowled along, we passed Audubon Island, an irregular rounded pile of rocks culminating in two prominences perhaps one hundred and twenty-five feet above the sea. The red of the granitic rocks contrasted well with the faint tinge of green vegetation that sparsely clothed the 


\section{WAPITAGUN}

summits. The island was undoubtedly named by Captain Bayfield in the summer of 1833 .

Off Coacoacho Bay is a small rocky island, - Outer Island or Île au Large, - on the summit of which, about forty feet above the water, a triangular beacon had been placed. Even from a distance we could see that the top of the rock was crowded with birds to such an extent as to lead Captain Joncas to exclaim: "This is the old times come back!" We were, indeed, fortunate, as it was evident that this year, at least, no one had visited the island. The red granitic rock was painted white with guano, against which the birds stood out black and prominent. From afar we could distinguish the strange black forms of cormorants, which we later found to be all of the doublecrested species. As we sailed nearer we saw that every foot that was not occupied by cormorants and their bulky nests was filled with murres standing erect in their black coats and white vests, while overhead hovered a dozen or more complaining great black-backed gulls. We landed on the rocks on the lee side, but in by no means calm water. Our landing-boat or tender was stoutly built and the captain's 


\section{IN AUDUBON'S LABRADOR}

habit was to run her bow on to a smooth rock at the top of a wave, and, after all had jumped out, to pull her up before the next wave struck. To our delight most of the birds remained at their posts even after we had landed in this rude and boisterous manner, and the botanist and I carefully stalked them with our cameras leveled. Soon we found ourselves among the cormorants' nests with murres on all sides. Although most of the adult cormorants had silently left, their kind was well represented by the young, who, crying vociferously for food, stretched their necks at us from the nests. They were extraordinary creatures, generally three, sometimes four, or only two in a nest. When small they were entirely destitute of down or feathers and of the color and appearance of an india-rubber doll. The large ones, from a foot to two feet long, were covered with a black woolly down suggestive of a toy black lamb. They were, indeed, weird objects as they thrust out their long snakelike necks and small heads. Their naked throatsacs, of a pale yellow color tinged with pink, distended and quivered as they constantly called in hoarse, beseeching tones for food. I 

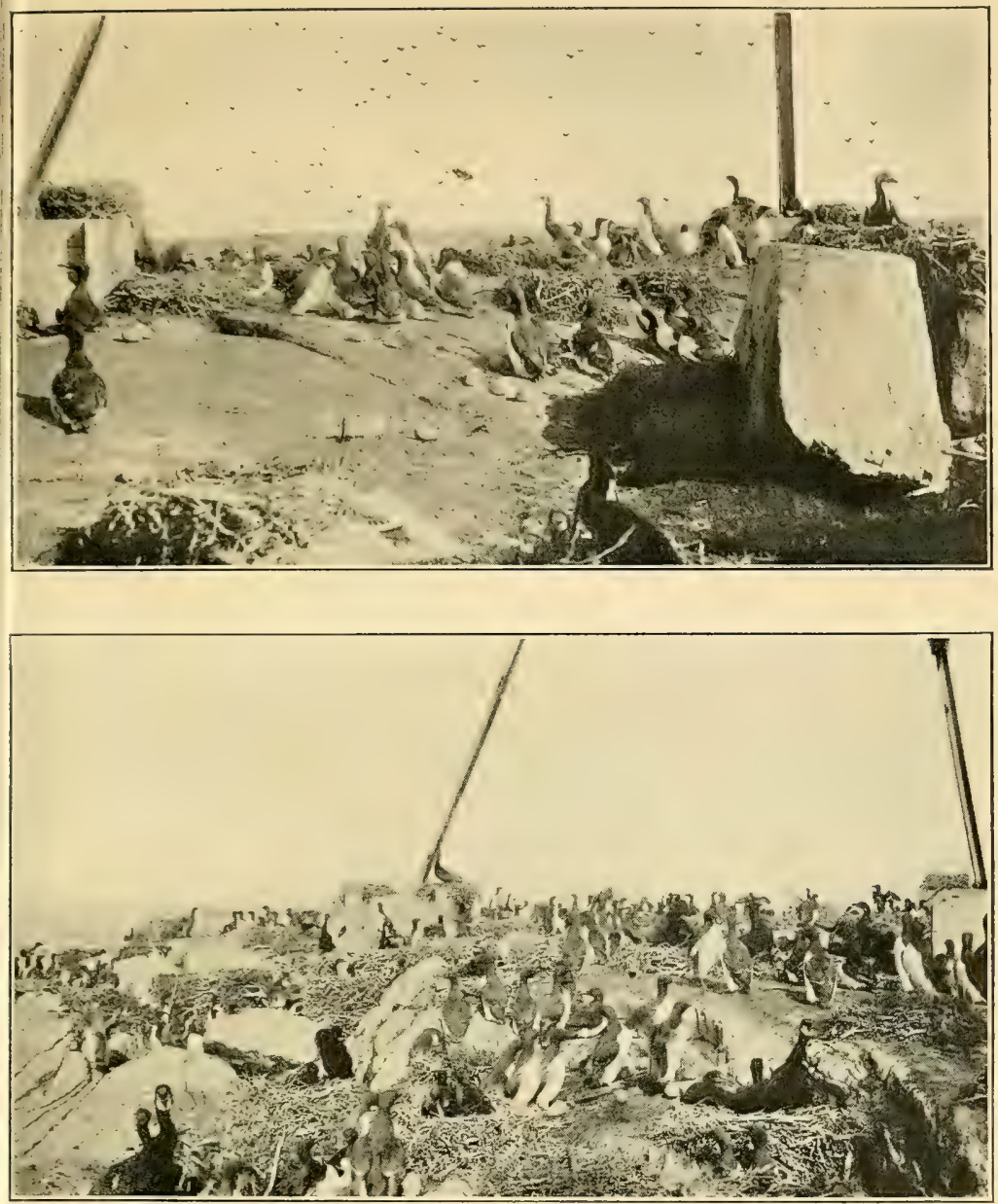

OUTER ISLAND: MURRES AND THEIR EGGS: DOUBLE-CRESTED CORMORANTS, NESTS, AND YOUNG 



\section{WAPITAGUN}

counted six hundred nests and there may have been more - great basket affairs nearly two feet across in outside measurements and built up from three or four inches to a foot in height. Several were placed astraddle of the lower frame of the triangular beacon. They were made of weed-stalks intermingled with dry grass and seaweed and branches of curlew-berry vine, spruce, and fir. Many of the nests, although much soiled with the chalky, slimy droppings of the bird, had some decoration in the form of a feather or two or a fresh green branch. I once found a long, curled woodshaving on the edge of a nest.

An interesting tale of decoration of the nests by cormorants was brought to our attention. I am inclined to believe this story from my knowledge of the habits of this bird, and as it was not solicited or even suggested on our part. It seems that a trading-schooner was sunk two years ago off Washsheecootai Point, and this summer, when some fishermen visited a cormorant island near by, they found that the birds had decorated their nests with pocket-knives, pipes, hairpins, and ladies' combs - objects which they had obtained by diving to the wreck. 


\section{IN AUDUBON'S LABRADOR}

A few of the nests on Outer Island contained eggs, and it was interesting to notice the small size of these eggs of the cormorant as compared with the large eggs of the much smaller murre. The latter bird builds no nest and lays its one beautiful egg anywhere on the rocks. The egg is curiously tapered so as to be much smaller at one end than at the other. This makes it roll in a circle about the smaller end and tends to prevent its falling from ledges. No two are alike in color or markings. They vary from white to brown and sky-blue and are marked as if by an erratic artist with a great variety of spots, lines, dashes, and blotches. These gems of beauty were, however, often sadly befouled so that no trace was to be seen of their exquisite coloring or marking, for the close crowding of so many birds, particularly of cormorants, produces an indescribable filth. The odor is one that clings to the memory as well as to the clothing.

The owners of these wonderful eggs were still more interesting, the murres, or marmettes as they are called here, - the foolish guillemots of Audubon and of English writers. They stood about in crowds and anxiously made 


\section{WAPITAGUN}

way for us, walking or running along erect with legs apart in a comical manner, as they waved their short, paddlelike wings to aid them in balancing. They reminded me at once of moving pictures I had seen of Antarctic penguins. In their anxiety and nervousness they frequently fell over the cormorants' nests and sadly stained their white shirtfronts in the mire, and often, in their attempts to rise on the wing, they would sprawl headforemost down the rocks. Occasionally we would see one try to arrange an egg against the bare incubating space in the middle of the belly. How each knows its own egg is a puzzle. During all this time they were as silent as the adult cormorants, but the young cormorants made noise enough for all.

A considerable proportion of the murres had narrow white eye-rings and white lines leading back from the eyes. This bird is known as the bridled or ringed murre, but is not given rank as a separate species, although it may deserve it. The fact that the common murre and the ringed one breed in the same colonies and that birds of both kinds have been found breeding together does not vitiate 


\section{IN AUDUBON'S LABRADOR}

this possibility, for hybridization among waterfowl is not rare. The ringed murre is certainly a marked bird. I retain a mental image of a group of fifteen or twenty murres standing huddled together, all of whom were ringed.

William the Pirate was anxious I should fire my gun and mark the effect on the birds, but this I refused to do, although I allowed him to catch a couple of murres - one of them ringed - for me for specimens and thus satisfy his lust for blood. We counted a hundred murres' eggs in a space ten feet square and calculated there were about two thousand murres, and, as there were six hundred cormorants' nests, about twelve hundred adult cormorants in the colony. When we returned to the schooner we first became aware of the curious noises made by the murres as they flew by us with a rattling ah-ah-ah. They col. lected in groups on the water and their combined voices produced a long-drawn, plaintive, moaning wail. At times it was a sharp snarl, at times it resembled the plaintive $b a a$ of a forlorn lamb. This bird resembles in general the razor-billed auk, but can be distinguished from the auk by its long, slender bill 


\section{WAPITAGUN}

and its very short tail. In the water the auk is apt to cock its tail up. In flight the legs of the murre extend out behind like a tail and like the same appendage are spread apart when the bird makes quick turns. In the auk the legs in flight are concealed under the tail. As far as I could discover there were no Brünnich's murres on the island. This bird, which prefers the narrow ledges of cliffs, occurs on the eastern coast and to a less extent on the southern. It is distinguished by a broader, thicker bill.

As we sailed away we had the pleasure of seeing the birds return at once to the island and of knowing that, although we had obtained much information in the form of notes and photographs, we had caused the birds but little anxiety or damage. I shudder to think of the devastation that would be inflicted by the arrival on the island of the crew of a fishingschooner, yet this arrival is more than a probability. The consideration of the prevention of this sort of thing and the conservation of the birds will be reserved for a later chapter.

Not far from Coacoacho Bay we passed Wolf Bay and could see the house of the only family 


\section{IN AUDUBON'S LABRADOR}

there, that of Gilbert Jones. This man, now in his eighty-third year, came here from Bradore Bay some forty years ago and he has reared a family of six sons and many grandchildren. His father was the squatter of Bradore Bay about whom Audubon has written so interestingly. Beyond his house to the eastward loom up the cliffs of Cape Whittle, rising from deep water to a height of one hundred and fifty feet. We sailed so close that it seemed a simple matter to toss a pebble or clam as in our case - against the rocks, but distances under these circumstances are particularly deceptive as we found by experience. The rocks were brown and red, daubed in places with great splotches of white where cormorants were nesting. The captain said that in former years the whole cape looked from a distance like an iceberg, but the birds are now nearly all driven away. Fishingschooners for years have been in the habit of sailing close inshore and the men have discharged their guns at the poor birds, for the brutal pleasure of seeing them fly off in terror and fall wounded into the sea. There were only fifteen or twenty nests on these cliffs, where up 


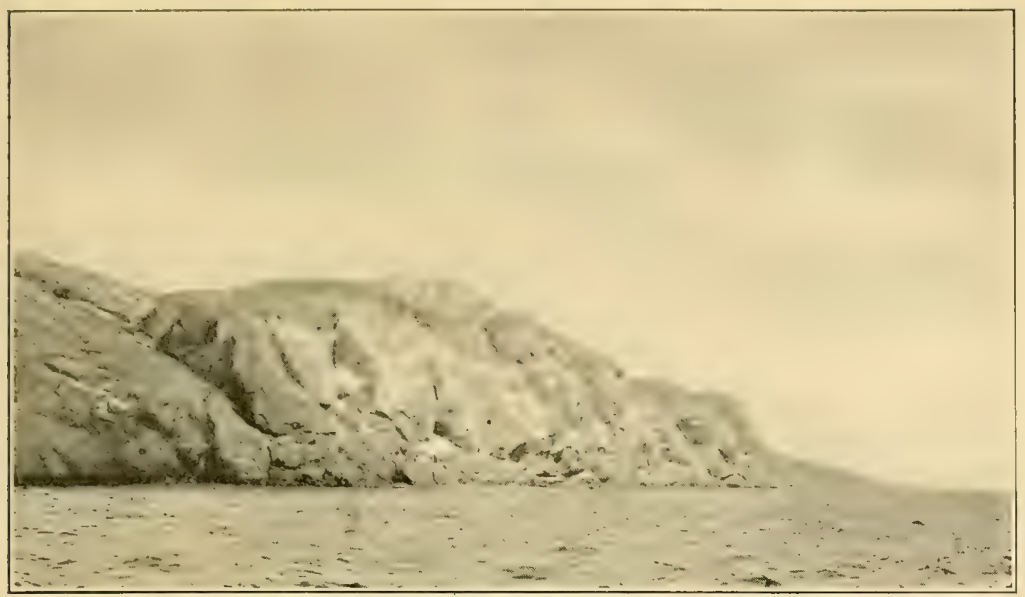

CAPE WHITTLE

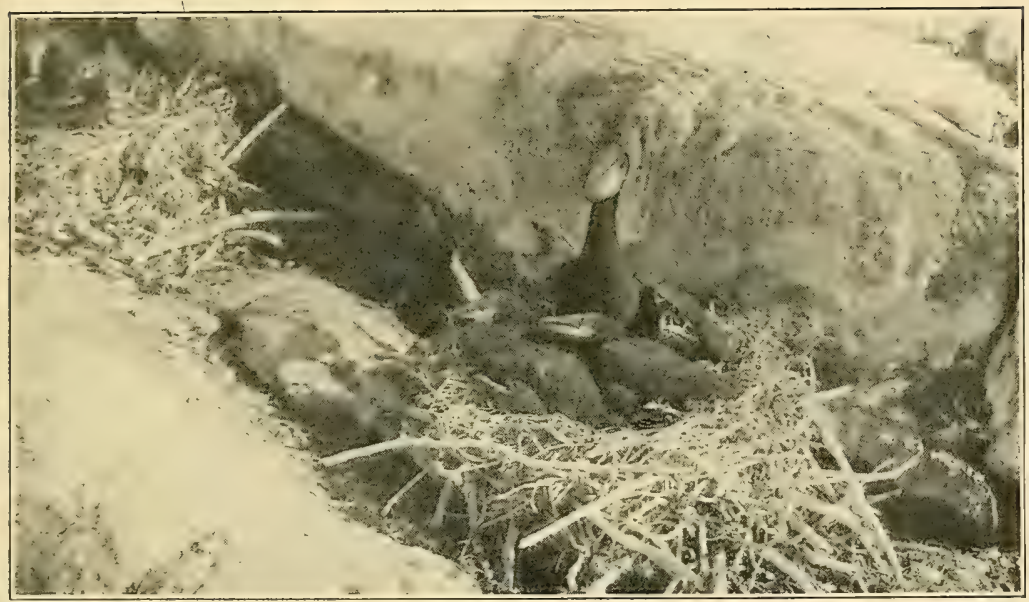

NEST OF DOUBLE-CRESTED CORMORANT CONTAINING YOUNG 



\section{WAPITAGUN}

to a few years ago they were to be counted by hundreds. Among the few birds that flew off from the cliffs at our approach, only one displayed the white markings about the neck which showed it to be a common cormorant, and not the double-crested kind that is so much the more common here. The common cormorants were really common in Audubon's day.

We found that the double-crested cormorant had taken refuge on the islands, for on landing on Gull Island off the cape we discovered that these birds were even more numerous than at Île au Large. How quickly birds respond to treatment, good or bad! The sound of a gun, no matter how distant, inspires terror in all the birds within earshot, and the mere appearance of a man, who is associated in the bird's mind with the noise of a gun and the accompanying pain and destruction, often causes the same terror. On the other hand, we found on these islands that if we moved about slowly and carefully, fired no guns, and avoided disturbing the birds in any way, they soon got used to us and remained on their nests or eggs. Cormorants are more timid than 


\section{IN AUDUBON'S LABRADOR}

murres, but on this Gull Island we were able to approach within two or three paces of some of the cormorants before they flew away from the nests where they were brooding their young. These birds are at first sight not pleasing to look upon, but both the botanist and I were much attracted by one individual who, as she brooded her young, displayed in her countenance - if I may use the word and in her whole bearing the tender emotions of motherly love. We approached her slowly and with great care and I finally stood within four feet of the nest. Addressing her in terms of endearment, I endeavored to stroke her back, but even a follower of Audubon could not inspire faith enough for this familiarity. I am sure that, if I could have visited this charming bird again, we should have been able to establish terms of mutual confidence. It reminded me of an experience of Audubon's on the cliffs of Cape Whittle opposite. He says, "I had the pleasure of coming immediately upon a Cormorant's nest, that lay in a declivity not more than four or five yards below me; the mother bird was on her nest with three young; I was unobserved by her 120 


\section{WAPITAGUN}

for some minutes, and was delighted to sec how kindly attentive she was to her dear brood; suddenly her keen eye saw me, and she flew off as if to dive in the sea."

Cape Whittle is itself the terminal point of a large island - put down on the maps as Lake Island. Next to this island is Wapitagun, and the Newfoundland fisherman, as he sails by, points to a great rounded rock on the cliffs of Misstassini - the island just outside - as a justification to him of the name Wapitagun, "a whopping great gun," for the rock looks like a mortar or great gun. The derivation is as curious a corruption of words as is that of the old hostelry in London known as the "Cat-in-the-Wheel Inn." The original name was "St. Catherine's Wheel." Wapita$g u n$ is of Indian origin and means cormorant, an entirely appropriate name for this region. This rock looked like a poised boulder left by the last glacial period, but poised boulders less than two or three hundred feet above the sea are unknown on this coast, for the reason that after the glacial period and before the present rising of the coast there was a submersion and the boulders were washed by the 


\section{IN AUDUBON'S LABRADOR}

waves into hollows. Occasionally a boulder is so firmly lodged in a cleft that it has not rolled away or has been lying in a harbor secure from the waves, but boulders such as these are rare. The captain said that he was told by one of the early Acadians that in former days there was a French settlement at this point, and that the great rock was rolled up to this conspicuous place as a beacon. If this tradition is true it explains to the geologist the apparent paradox of a poised boulder on a previously submerged coast, or, as the botanist put it, "it lets the geologist out in great shape."

After leaving Gull Island we sailed by the point of Cape Whittle and entered the passage which leads to the protected harbor of Wapitagun. Audubon in his account of the razor-billed auk gives a theatrical description of the Ripley's entrance into the same harbor: "Springing upon the deck, and turning his quid rapidly from side to side, he called out, 'All hands square the yards,' and whispered to me, 'All's safe, my good sir.' The schooner advanced towards the huge barrier, merrily as a fair maiden to meet her beloved; now she 


\section{WAPITAGUN}

doubles a sharp cape, forces her way through a narrow pass; and lo! before you opens the noble harbour of Whapati Guan. All around was calm and solemn; the waters were smooth as glass, the sails fell against the masts, but the impetus which the vessel had received urged her along. The lead was heaved at every yard, and in a few minutes the anchor was dropped."

The harbor of Wapitagun is a long, protected passage between Wapitagun on the north and Misstassini and other islands on the south and east. Wapitagun itself is a great island about three miles long by over a mile broad. It is a region of rocks and bogs, of pools and lakes, of lichens and mosses, arctic flowers and creeping birch and spruce. In one of the lakelets in a flat barren was a pair of red-throated loons that rose into the air at my approach, and flew about high overhead, croaking dismally. Their son and heir in his coat of light-brown furry down had left the nest, and was vigorously swimming about. The old birds were dressed alike, and wore a handsome livery, pure white below, relieved only by a broad strip of terra-cotta red on the 


\section{IN AUDUBON'S LABRADOR}

throat. The upper parts are slate blue; the back of the neck is slashed with wavy lines of white. Whabby is their name among the English-speaking people of the coast. It was used by Cartwright in the eighteenth century.

In a dark, deep valley with precipitous sides I came upon a picturesque tarn. From among the alders which crowded its outlet arose the song of a winter wren, a bird recorded by Audubon at Wapitagun, possibly at the same place. I did not attempt to find it in the tangle; one might as well look for a mouse in the same situation. The hills about, although barely two hundred feet high, were mountainous in appearance. In these rugged surroundings where it is difficult to estimate size, one has often a feeling that he is looking the wrong way through binoculars, and it seems much more appropriate to speak of lakes and mountains than of pools and hills.

On my return the trill of a least sandpiper was borne to my ears, and, in a quaking bog where footing was most uncertain, I found this charming bird indulging repeatedly in the nuptial song. He would rise on whirring wings like a mechanical toy and sail in irregu- 


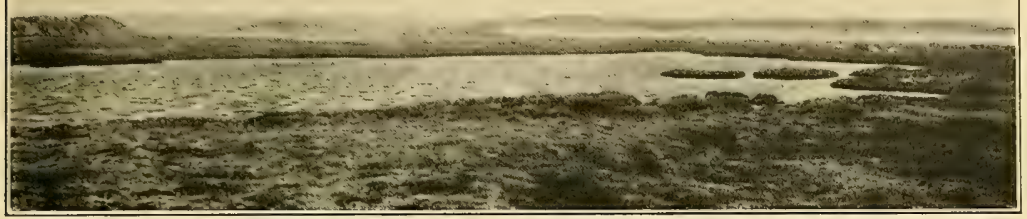

WAPITAGUN: NESTING-POOL OF RED-THROATED LOON



RED-THROATED LOON

Audubon Plate 



\section{WAPITAGUN}

lar circles twenty to fifty yards above the bog with wings curved downwards and backwards, emitting at frequent intervals a short trill almost as finely drawn as that of a cricket. He was in the air for five minutes by the watch and continued to trill after he had reached the ground. Here he was at once obliterated, for his streaked brown back was next to invisible in the bog. He continued trilling as long as I was within earshot, and he even followed me, repeating his simple song.

The botanist and I met by appointment on the shore and were picked up by the Sea Star and carried as through a rock-lined river to the favorite harbor of the captain's father. Black guillemots and razor-billed auks fluttered here and there and everywhere as we sailed along. The harbor was opposite Matchiatik Island, where, some years ago, in a calm with a heavy sea a schooner nearly came to grief on the rocks. The men, thinking she would pound herself to pieces, jumped ashore. No sooner were they in safety than a puff of wind came and their deserted schooner sailed off, but was fortunately captured by a friendly vessel and returned to the crew. 


\section{IN AUDUBON'S LABRADOR}

We had had an exciting day, so crowded with interesting episodes that it seemed a week since we had successfully broken away at three that morning from the storm-bound harbor of Old Romaine. 


\section{CHAPTER VI}

AS FAR AS DR. GRENFELL'S HOSPITAL AT HARRINGTON

ATER ten hours' sleep in clear, cool air on 1 balsam boughs spread on deck, and after the dash of the eye-opening bucket of seawater, we were fit for whatever the day should bring forth. Our first objective point, while the morning breeze was gathering strength, was the protecting harbor island of Matchiatik. $^{1}$ Here, so the captain told us, Jean-Baptiste Galibois narrowly escaped disaster forty years ago in attempting to make our harbor in a storm, a storm that sank six schooners and drowned many brave men. Jean-Baptiste's vessel miraculously escaped the rocks, passed through the narrow and turbulent passage, and rode in safety in the quiet anchorage of the little harbor. Out of gratitude for his deliverance he erected on Matchiatik Island a large wooden cross, which has served all these

1 This name is wrongly given on the charts to an island several miles to the northeast. 


\section{IN AUDUBON'S LABRADOR}

years as a sacred memorial of the event, and as a beacon to voyagers along the coast. It had fallen down, but the captain and William put it back in place and braced it with timbers and great rocks. I trust that this pious service will atone for the slaughter by William the Pirate of two young great black-backed gulls, but the crime rests heavy on my conscience and I confess that I noted in my journal my enjoyment of the delicacy of their flavor. How easy it is to revert to the savage! For my own justification I will add that, with the exception of these and two other victims, I permitted no birds to be killed for food alone on this expedition, but we used for food those whose skins I preserved for scientific purposes. This, as I have explained elsewhere, is an interesting exception to the rule that "one cannot eat his cake and have it too."

What views of gray rocky islands and sparkling blue waters, and again rocky islands and blue waters - all tumbled about in wild confusion - all alike yet all different! With the exception of the great weather-beaten cross, - symbol that means so much, - all, both water and rocks, were destitute of any trace 


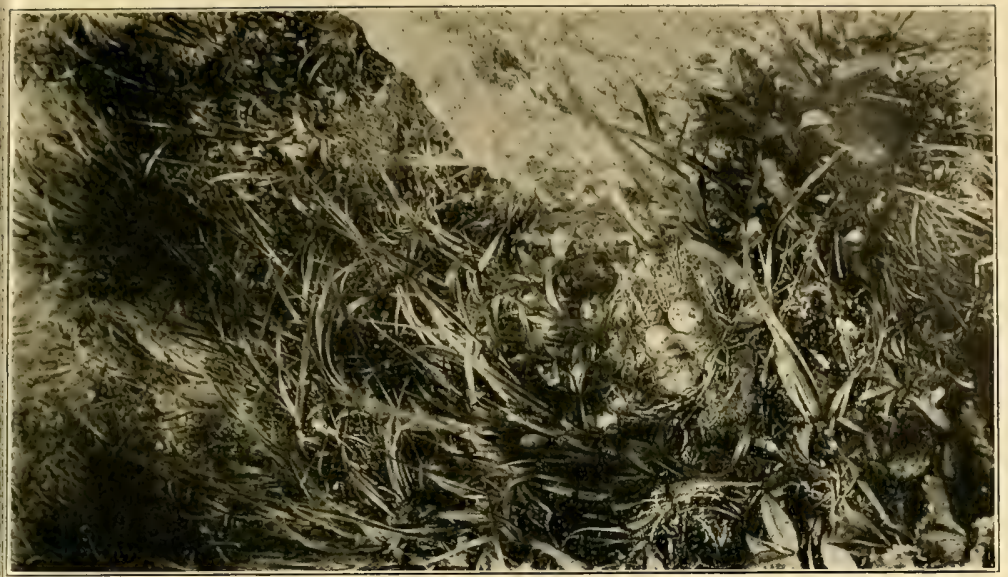

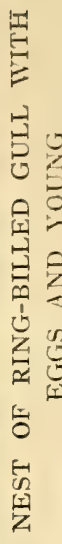

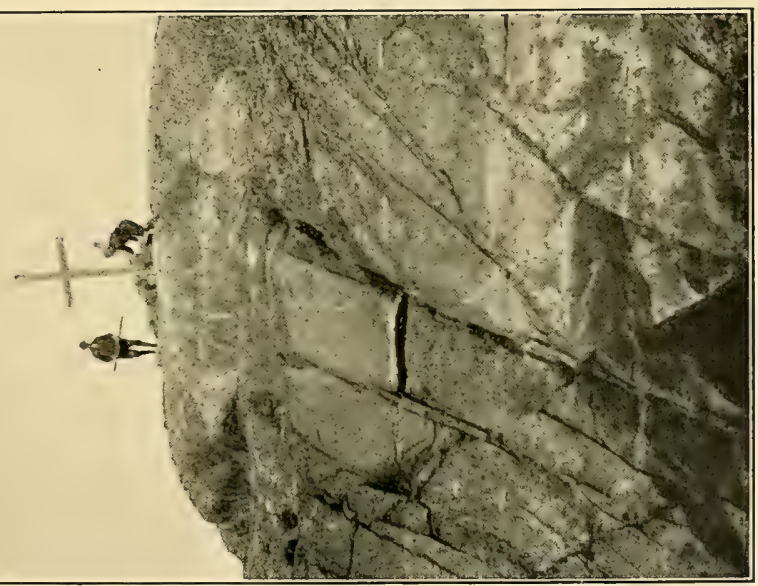

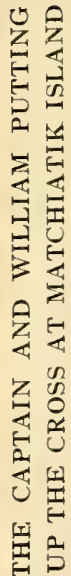





\section{AS FAR AS HARRINGTON}

of man. It is good for the soul to escape to a wilderness like this, especially in these terrible days of world carnage, and I rejoiced in the mere fact that I was alive, and noted in my journal, "This is the life!" Captain Hearn of the Cascapedia was partly right, but an occasional sojourn in a wilderness enables one also to endure and be happy in the crowded city.

Pipits wagged their tails and walked nervously over the ledges, horned larks rose into the air to pour out their morning song of thankfulness, auks and sea-pigeons popped out of unexpected clefts in the rocks and joined their companions at a safe distance on the waves, - all this the botanist and I saw as each on his special mission explored the island. But we were no narrow specialists, and on this occasion I happened on a botanical specimen which surprised the botanist. It was a pinguicula, a blue flower rising from a tuft of leaves and looking superficially like a violet. The leaves, narrow and pale green, curl at the edges and secrete a sticky fluid which attracts and catches minute insects. It is, in fact, like the sundew, an insectivorous plant. The botanist had found it abundant on the 


\section{IN AUDUBON'S LABRADOR}

limestone Mingan Islands, and expressed mild scientific skepticism when I told him I had found it in former years on Battle Island and other granitic and gneissoid lands. Plants as well as animals do not always obey the rules. I wonder whether Audubon mistook this flower for a violet; he says: "A beautiful species of violet was found, and I have transplanted several for Lucy, but it is doubtful if they will survive the journey."

The pipit is worth more than passing mention. Like the horned lark it is a bird of the barren Arctic Zone. Its trig form and Quakergray and brown plumage, its dovelike nods in walking, and its habit of wagging the tail - all make it attractive. Like the horned lark it sings in the air, but a different refrain and delivered in a different way. It sings as it flies up obliquely to a height of perhaps two hundred feet, then it turns and descends with great speed, singing as it goes. The song is simple, a loud che-whee, with a vibratory resonance on the whee. On one occasion I saw a male alight near his mate and flutter his wings excitedly; at the same time he repeated his song so rapidly that it merged into one refrain. 


\section{AS FAR AS HARRINGTON}

The Sea Star did well in the light airs and head sea, and I had a chance to think over the crowded events of the day before. At noon we were five or six miles au large and the captain was taking soundings near some unmarked shoals. St. Mary's Island with its lighthouse and bird-colonies was outside us and unattainable. At a protected harbor in one of the Galibois Islands we saw the first men we had seen since leaving Old Romaine. Picturesque fellows they were, in oilskins and large sou'westers - one wore a carmine tamo'-shanter. They were visiting their cod-traps in stanch boats. Birds were scarce in this region, for fishermen, alas, do not live wholly by fish. Yankee Harbor, on the other side of these islands, is also a favorite harbor for fishermen.

We were fortunate in reaching the little protected harbor of Seal-Net Point or Pointe au Maurier that night. Here, in a house painted yellow with a brown roof, lived Joe Galibois, a gray-bearded old man whose father doubtless was living there in Audubon's day, for his is one of the oldest families on the coast. Joe had lived here for fifty-seven 


\section{IN AUDUBON'S LABRADOR}

years and his nearest neighbor lives three miles away over rock-strewn waters, but he was in touch with the great world, for the telegraph and the mail station are here. Fish, which means COD spelt with capitals, were "striking in," and all hands were busy at the splitting-table. Fish-heads and other refuse abounded; the air reeked with them and the dogs were fat and lazy.

A successful season means everything to the Labrador fisherman. In six weeks to two months he may lay by enough to live in comfort the rest of the year. This is his earning season and fisherman's luck, good or bad, means for him either a feast or a famine. We heard of a hundred quintals of fish taken in two days, of fifty quintals taken from one trap, and twenty let go free as there was no more room in the boats. A quintal (pronounced kentle) is one hundred and twelve pounds of dried salt fish, and is worth on the coast five dollars. About one hundred and twentyfive three-pound cod are needed to make up a quintal. After a short successful season the fisherman lays in a stock of essentials - flour and pork and molasses - and as many luxu- 


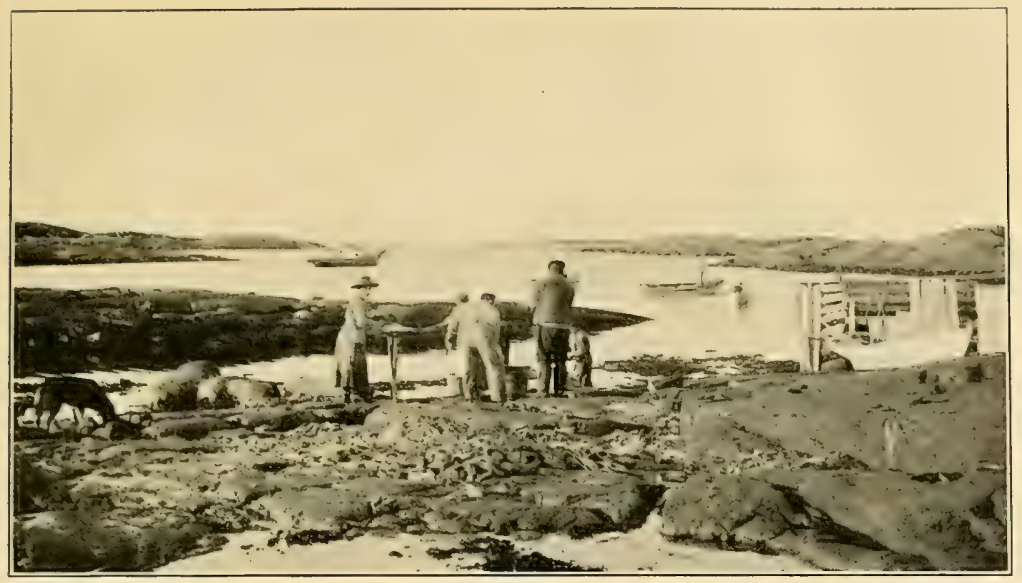

CLEANING FISH AT SEAL-NET POINT, OR POINTE AU MAURIER

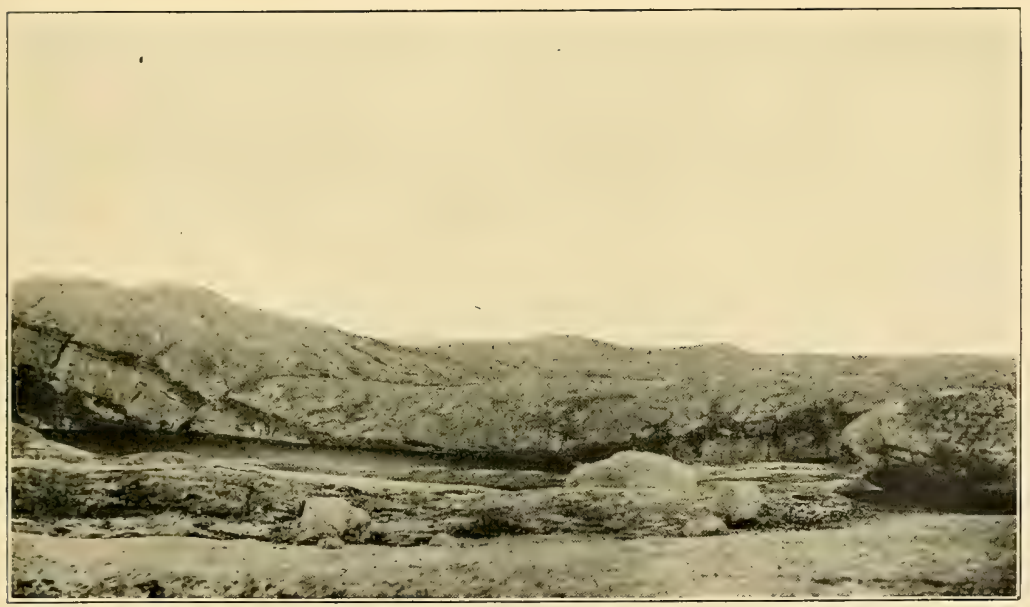

NEAR THE SUMMIT OF LITTLE MECATTINA: POISED BOULDERS 

ries as he can afford, retires to his winter house at the head of some protected bay, and settles down to a long winter season of comparative leisure. He traps, - and there is always the lure of a black fox and riches, - he cuts wood, and visits his neighbors. Winter traveling over the ice on komatiks, or dog-sledges, with a good team of seven or eight dogs rapidly shortens a forty-mile space between him and a neighbor. Latchstrings are always hanging out, and the unexpected arrival of a whole family to spend several days or a week is taken as a matter of course, and every hospitality possible is dispensed. Sometimes the appearance of the stove and larder shows in the morning that a traveler in a hurry had availed himself of the customary hospitality of the country during the night, and had gone his way without a word. I asked a number of men along the coast how they liked the winter, and their eyes sparkled as they spoke of its pleasures. Spring and fall they shoot migrating ducks and net and shoot seals, and before the cod strike in, some of them net salmon, for which privilege they pay the Government a tax of three cents a fathom of net. 


\section{IN AUDUBON'S LABRADOR}

It is a sporting life and develops independence and strength of character; Labrador is no place for weaklings.

It is well to mention this bright side of the picture, for, as the fisheries fail more and more from year to year, one hears only of insufficient clothing and scanty food, of scurvy and beri-beri, of slow starvation and death, until some think this is the universal condition on the Labrador coast and that each village is

"A hungry village by a hungry sea,
As worn and gray as any Calvary!"

It has even been urged that the people be all transported to more favorable regions. The fact is, there is poverty everywhere, especially among the ignorant, but after all "there is no place like home," and a love of one's native land is possessed by all. As I have just shown, life in Labrador may be extremely pleasant, and with sufficient food and clothing no one minds the winter. Captain Cartwright wrote that he was often chilly in England, but never in Labrador, and my Belgian friend has confirmed this. I believe that through conservation and education the life of the Labra- 
dorians will become more and more desirable. I asked William and Ernest where they would prefer to live if they had plenty of money and could choose, and they both said, "On the coast."

"The shudd'ring tenant of the frigid zone Boldly proclaims that happiest spot his own;

Extols the treasures of his stormy seas, And his long nights of revelry and ease."

Barren and bleak was Seal-Net Point, and on the second day fog and rain and storm rolled in from the Gulf, so that the Sea Star pitched and tugged at her anchor-chains, yet these two days were not grudged by us. In the first place, the botanist found plenty of pinguiculas and many other arctic plants which cheered his heart, while I was so thrilled by finding on the first day the breeding-place of ring-billed gulls that I was buoyed up by the memory during the succeeding storm, and the odor of fish that hung about the little harbor was as incense in my nostrils.

The ring-billed gull is about two thirds the size of a herring gull, but wears very similar plumage. It breeds commonly in British Columbia and in the northwestern part of the 


\section{IN AUDUBON'S LABRADOR}

United States, but Audubon in 1833 found it breeding in Labrador. There is some confusion about it, however, and it is probable that the European mew gull, which he also reported as breeding, was in reality this species. Frazar in I884 found a few moderate-sized colonies of the ring-billed gull in the vicinity of Cape Whittle. Aside from these records very little is known of this interesting bird in Labrador, and my delight at finding a breeding-place may be imagined.

Off Grand Romaine I first saw a group of these birds, and Captain Joncas at once recognized them and called them mauves. Near Pointe au Maurier was one of the very numerous Îles des Goélands, or Gull Islands, and I saw ring-billed gulls flying over our little harbor on their way to and from this spot. Galibois called the island his poulailler, or poultry-yard, where for many years he had obtained every spring a supply of fresh eggs for the table. The birds had not been disturbed in any way after the first eggs were taken; they laid a second set and brought up their families in peace, so that their numbers had increased rather than diminished. 


\section{AS FAR AS HARRINGTON}

We rowed over to the island the next morning and were greeted by a chorus of protests as about four hundred of these beautiful white birds rose into the air. They remained above our heads and protested so violently that I felt extremely guilty and worked as rapidly as possible, taking photographs of nests and eggs and young and recording my notes. I suppose the gulls took us for Newfoundland fishermen, and I pictured to myself their surprise and joy on finding that we had taken so little toll and had not wreaked the usual fisherman's destruction.

The nests, thickly scattered among the rocks and vegetation, were made up of neatly arranged dried grass and weed-stalks and moss and feathers. They contained one, two, or three chocolate-colored or bluish eggs more or less thickly spotted and scrawled with brown. Some of the nests contained downy young, gray and spotted. Many were empty and the young were concealed in the grass or well protected by their coloration among the rocks. That was, indeed, a red-letter day, and Audubon's spirit must have rejoiced with me.

After the survey of this precious island, - 


\section{IN AUDUBON'S LABRADOR}

and may it always have as good a keeper as old Joe Galibois! - we explored the islandcrowded bays leading up to the outlet of the Darby River. Windlasses on favorable points showed where nets were stretched to catch the seals returning from the bay. The sealnetting season extends from the middle of November until the last of December, but of late years this, like the other harvests of the sea on the Labrador coast, has fallen off. From time to time in our summer voyage we saw a seal stick his head above the water and gaze open-eyed at our boat; but they were far from abundant and nearly all harbor seals, a species still common in places on the New England coast. People here call them loup-marin d'esprit, while the larger harp seal, the seal of the Newfoundland Labrador, is called loupmarin brasseur. We saw one gray seal, called here the horse-head seal, a beast sometimes nearly twice as large as the harbor seal.

The bay proved to be well worth exploring, full of steep, rounded islands and abounding in the two birds that can best withstand the assaults of the fishermen. These are the razorbilled auk - the tinker of the English, the 


\section{AS FAR AS HARRINGTON}

gude or godde ${ }^{1}$ of the Acadians - and the black guillemot, or sea-pigeon. Both of these birds lay their eggs in deep crevices between rocks, places where the eggs and young are fairly safe. Gulls and eiders, which formerly abounded here and laid their eggs where all could see them, had but few representatives left, while murres with their confiding ways were nowhere to be seen.

Razor-billed auks are amusing birds to watch. Like penguins they sit bolt upright on the rocks that have been changed in color from red to white by their droppings. Occasionally we saw solemn lines of them on the ledges, and again a group of twenty together, many facing each other as if they were having a discussion. When disturbed they flew about the rocks like flies and later gathered in crowded groups on the water. I counted fifty in a space perhaps fifteen feet long and three feet wide swimming with their rather long tails cocked up behind. This long tail and the bill shaped like a Roman nose are good

1 Jacques Cartier used the word godez, which is perhaps the same word, when he referred to these birds and to murres. He also used the word loup-marin for seals, while the modern French is phoque or veau marin. 
fieldmarks in flight. The razor-billed auk lays a single egg on the bare rock at the bottom of a crevice or in the space below some fallen fragment. The young are strange-looking babies, make a peeping noise, climb about actively, and hide in the cracks.

Black guillemots, or sea-pigeons, were common everywhere along the coast. At Old Romaine $\mathrm{I}$ had first found their downy young, black as soot and peeping like chickens or making hissing noises. Here they were abundant and the old birds fluttered ahead of us over the water like great black-and-white bumble-bees. As they dropped into the water with a splash, they elevated their black wings, marked with great white blotches on the outside, straight up over their backs, and displayed the equally striking white lining. As they flew by, their brilliant scarlet feet ${ }^{1}$ were to be seen extended behind. In one group I counted fifty-four birds, and I suspected that they were courting from the excited manner in which they were weaving their ways in and out of the assembly. I have learned that

1 Cartwright mentions the use of the scarlet feet of these birds by the Indians for catching salmon, "in the same manner as we do a fly." 


\section{AS FAR AS HARRINGTON}

this "afternoon-tea" appearance among a group of water-birds generally means courtship, so I was all attention and watched the group closely. Many were dipping their heads nervously into the water as they swam, and presently I saw a couple circle about each other as if they were doing the lady's chain. Their mouths were wide open and displayed the bright scarlet lining. Occasionally the excited birds bobbed towards each other and dabbed with their bills. Their tails were cocked up and their red feet showed plainly in the water. Others performed in the same way and I could hear frequent hissing, whistling notes. It was no doubt the nuptial song and dance, the courtship of the black guillemot.

On July 18 we set sail for Harrington and drifted slowly along with the light airs. Off Juliet Harbor we were boarded by a fisherman who had rowed out for a little Sunday-morning gossip. As he leaned from his boat on the gunwale of the Sea Star he told us with enthusiasm of his success in fishing, but he looked very sheepish when the captain asked about his three-months-old twins. Twins 


\section{IN AUDUBON'S LABRADOR}

seemed to be common on the coast. His is the only house in Juliet Harbor, and a fine harbor it is, big enough to float a fleet of fishing-vessels. To the north lay the encircling hills and through a rift flowed a stream whose falls looked white as snow in the dark forest.

As we advanced, the hills rose to a height of seven hundred feet a short distance from the shore, and were broken and faulted from north to south in such a way as to display vertical faces to the west. In the shelter so formed the trees have grown to a considerable size, and patches of light-green birch showed conspicuously amongst the dark spruces. The red of rocky cliffs and the gray-and-white lichens on the exposed hillsides contrasted well with these greens.

Near at hand a long yellow sand beach fringed with white breakers and backed with pale-green strand wheat skirted a shore that was broken by the mouth of the Netagamon River. The falls, some fifty feet high, whose spray rose like smoke in the black forest, invitingly called us, but we needed to take advantage of the freshening breeze and we continued on our way only to fall into the doldrums 


\section{AS FAR AS HARRINGTON}

of a calm. Reefs were all about us, and over these great seas were curling and breaking. The captain took pencil notes of his soundings from time to time, for he said, "when I put them in my mind they rub out"; but of this I saw no evidence, for he never referred to notes or chart and seemed to know every shoal.

The breeze at last favored us, as a result doubtless of the persistent whistling of the crew, - an expedient faithfully resorted to by them in calms, - and we reached Harrington. This is a little fishing-village of some thirty families clustered on rocky islands about a snug harbor. We at once visited Dr. Grenfell's hospital on the main island of Harrington and were disappointed to find that it was empty of patients and physicians alike. Dr. Hare, after nine years of hard work here, had just retired to an orange farm in Florida, and his successor, Dr. West, who came with us on the Cascapedia, was away visiting patients. The hospital, doctor's house, two churches, - Anglican and Presbyterian, and a dozen or so comfortable houses, besides fish-stages, are nestled securely under the bold 


\section{IN AUDUBON'S LABRADOR}

rocky hill which rises on the north to a height of five or six hundred feet. On a spur above the hospital is a Marconi wireless station. Across the harbor to the south is the low-lying Fox Island with its cluster of homes and fishhouses. Opposite this to the east across a narrow passage is Gull Cliff Island with its high cliff facing the west. Here also are about a dozen houses, while on Shag Island, that forms the southeastern barrier for the harbor, there appears to be only one dwelling-house.

The hospital itself was neat, well arranged, and thoroughly modern in its equipments. The operating-room had a good light, and contained modern tables, sterilizers, and so forth. The wards were bright and cheerful, and each bed was marked with the name of the generous supporter. The verandas arranged as sunrooms opened on the south to a beautiful view on this lovely summer's day. I could imagine the wonderful prospect in winter over snowand-ice-covered rock and sea, all sparkling in the sun.

Harrington is the westernmost of the chain of hospitals established by Dr. Grenfell. One has but to glance at the map published in 
"Among the Deep-Sea Fishers" - the official organ of the International Grenfell Association - to realize the magnitude and variety of the work of this man. The headquarters of the mission are at St. John's, Newfoundland, in the King George the Fifth Seamen's Institute. This institute is one of the greatest blessings to all the seafaring men who ply along the Labrador coast. The chief hospital is at St. Anthony in the northern part of the island of Newfoundland. Here are seven wards, a bacteriological and pathological laboratory, an X-ray room, and a modern operating suite. Dr. John Mason Little, Jr., who came for a summer, remained in charge ten years. At St. Anthony there is also an orphanage for twenty-five children, and an industrial house, which contains a carpenterand-machine-shop, a pottery-kiln, and a room for spinning and weaving. There is also a mission school and a guest-house for volunteer workers. Fortunate is the college student who spends a summer working for the mission, because he realizes as never before the joy of service. The effect on his character must be a lasting one for good. Besides college students, 


\section{IN AUDUBON'S LABRADOR}

well-known specialists in various branches of medicine and surgery have from time to time given their services to the mission. There is also a coöperative store at St. Anthony, now known as the "Spot-Cash Coöperative Company, Ltd.," and another farther north at Cape Bauld and one at Flower's Cove. There is a school at Carrol's, a sawmill and agricultural station at Roddickton, and a hospital at Pilley's Island.

On the Labrador Peninsula, besides the hospital at Harrington, there is one at Battle Harbor and one at Mud Lake near the head of Hamilton Inlet, and a summer hospital at Indian Harbor. Then there are coöperative stores at West St. Modiste, Red Bay, Spotted Island, West Bay, and Paul's Island, a winter station for Battle Harbor at St. Lewis Inlet, industrial stations at Red Bay and Battle Harbor, a school and dispensary at Spotted Island, and a small store at Adlavic. Finally there is a "Mission Fleet." The good hospital ship Strathcona continues to float and work notwithstanding the perilous ice, rocks, and storms. The George B. Cluett is an auxiliary three-masted schooner, the Amber Jack is an 


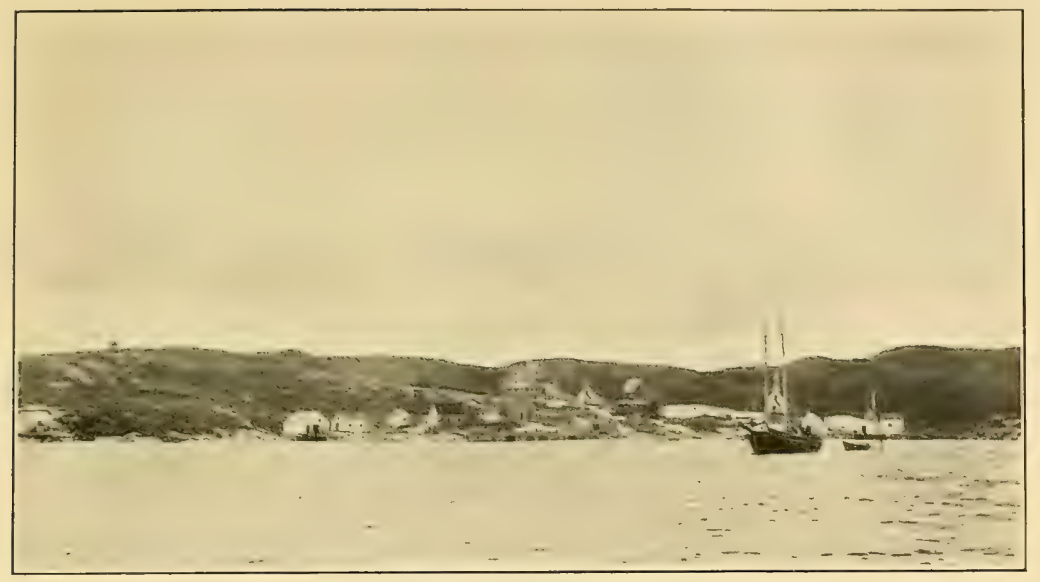

HARRINGTON

The Hospital is the large building in the center

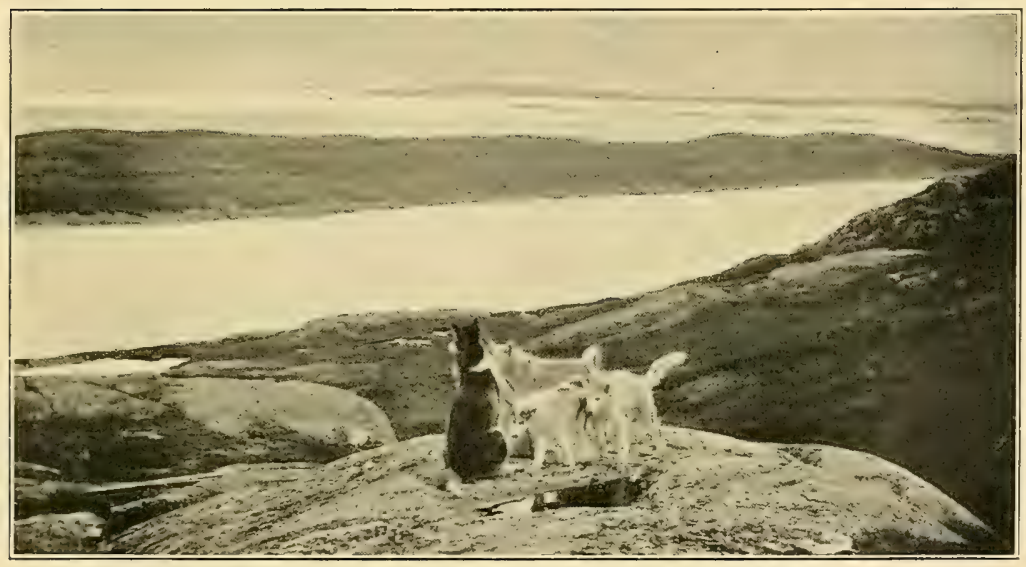

OLR FRIENDS THE ESKIMO PUPPIES AND THEIR MOTHER AT HARRINGTON 



\section{AS FAR AS HARRINGTON}

auxiliary yawl, and there are several smaller motor-boats all doing good and valiant service.

Dr. Grenfell's work will go on after he is gone, for he has imbued many workers with his spirit. It is doubtless at times uphill and thankless work, for there are always evilthinkers and hostile critics of good works. In this age of the mailed fist, when spiritual things seem as naught, the Christlike spirit of the work is refreshing. A poor lad with a diseased hip-bone, who had lain in bed a year, said to Dr. Grenfell, "Doctor, how can I do anything for others?" To which he replied, "Why, look cheerful, and be grateful, and purr when you are pleased. Cheer the doctor and the nurse, and the man in the next bed. That's what Christ would do. Go and do likewise."

Our climb to the top of the island was enlivened by the affectionate companionship of four white Eskimo puppies, who, with their dark-haired mother, had greeted us outside the hospital. They were full of spirits and always ready to romp, and when we tired of their play they would gambol over their mother until she sedately and sternly quieted 


\section{IN AUDUBON'S LABRADOR}

them. The Eskimo dog is as gentle and affectionate and as fond of human companionship as any dog when properly treated. My experience here at Harrington and elsewhere bears this out. At Battle Harbor I once enjoyed the friendship of one of Dr. Grenfell's dogs and found him as intelligent, trustworthy, and lovable as any well-brought-up canine. The vast majority of Eskimo dogs in Labrador are, however, savage and treacherous, and unless this is borne in mind it is dangerous to go among them. There are numerous instances of these dogs turning on men and children who had fallen down among them, and tearing them, sometimes fatally. If one dog springs at a human being, all the other dogs of the pack are incited to follow suit. A bold front, care not to trip and fall, and the use of a stout staff or a large stone will keep the dogs at a distance. Strangers from ignorance are generally less watchful of the dogs than are the natives. The reasons for this savage disposition are not far to seek. In winter the dogs are generally insufficiently fed, and worked hard and abused. In summer they are generally not fed at all, but are left to pick up 


\section{AS FAR AS HARRINGTON}

their own living. This they obtain from the fish refuse and at the expense of the birds nesting along the shore. At all times they are kicked and cuffed and are never kindly spoken to or affectionately treated. That they respond favorably to kind treatment the exceptions just given show, and these exceptions prove the rule that dog-nature is essentially a lovable one and faithful to mankind.

The dog question is certainly a difficult one, however. The animals are at present essential during the long winter season. Without them transportation over long distances would be impossible; they are the only beasts of burden on the Labrador coast, but they impose many burdens on the inhabitants besides the question of their food and their dangerous nature. The Labradorian is unable to grow even the few vegetables the climate allows unless he fences in his garden from the dogs with a strong and high fence. Poultry, pigs, goats, or cows, all of which might otherwise be kept, cannot survive unless, as at Natashquan, the dogs are imprisoned in stout stockades or kept chained. Some day it is to be hoped that the reindeer, which Dr. Gren- 


\section{IN AUDUBON'S LABRADOR}

fell has introduced in northern Newfoundland and which have proved so useful in Alaska, will take the place of the dogs in Labrador. The original herd of three hundred reindeer brought to Newfoundland from Lapland in I908 has now increased to one of twelve hundred. There is an abundance of food for the animals in Labrador, and it is a food they can procure for themselves, for the reindeer, like his near relative the caribou, thrives on lichens and mosses. The reindeer will do the work of dogs, and much more. As Dr. Grenfell has expressed it, the reindeer will bring "milk for babies, meat for men, transport for mails, freedom from dogs, possibilities of gardens and domestic feasts, warm clothes for winter, and many other blessings to the people of our coast." The Eskimo dog is the chief obstacle in the way of the introduction of the reindeer, and may prove a fatal one.

From the top of the hill we had an extensive view on all sides. Below to the south and fringing the harbor lay the little fishing-village, and beyond the islands the sea spotted with foaming reefs. To the east across a stretch of water loomed the high and rugged 


\section{AS FAR AS HARRINGTON}

land of Little Mecattina; inland was a maze of low-lying land and water with higher land beyond; towards the setting sun more water, small islands, and an immense flat coastal plain, a boggy, barren land. We descended through a valley whence the snow had evidently just gone, as was shown by the brown and dead vegetation of the previous summer and by the fresh buds of the spring vegetation. Alders were hanging out their yellow catkins and some of their leaves were just unfolding, although close beside them other alders had long since passed the stage of these early activities.

It was rather a relief to find the people all speaking English here, although I could not help noticing the lack of polite greetings with which we were familiar among the French inhabitants of the coast. One boy addressed us with the remark, "Some 'ot, hey?" and they were all complaining of the heat. My thermometer registered $65^{\circ}$, but it was said that at Sam Cox's house, where there was a thermometer, the mercury had reached $72^{\circ}$, and many had come to look at it. Part of their sufferings may have been due to the fact that 


\section{IN AUDUBON'S LABRADOR}

they were all in their Sunday best, and an English Sunday is proverbially oppressive.

That evening we were lulled to sleep on the deck of our little schooner by the mournful chorus of the howling of Eskimo dogs, a chorus that was taken up by one group after another in the village. It is a weird sound and suggests the rush of winds through rocks and crags, wolf-packs on dreary Arctic wastes, and Eskimo snow villages in the remote North. It is a crude, primeval sort of music, not without a certain wild charm and beauty. 


\section{CHAPTER VII \\ LITTLE MECATTINA ISLAND AND \\ MUTTON BAY}

$H^{R O M}$ Harrington Harbor we sailed directly a mass of purple clouds edged with rose. Below them lay the mountainous island of Little Mecattina, which, looking like a series of rocky waves advancing towards the Gulf, loomed in the distance. The island was wonderfully beautiful in the purple morning shadows, but stern and forbidding. A glorious luminous haze was all about us as we bowled steadily along with all sails set. The westerly wind had been quieting the waves during the night, but there was so much sea left that we were thankful the captain had decided to spend the previous night in a secure harbor and not push on. Audubon had sailed from Wapitagun directly across to Little Mecattina, losing all the intervening interesting land and islands, and for two days and a night was subjected to the discomforts of seasickness. 


\section{IN AUDUBON'S LABRADOR}

As we approached the island and passed Cross Harbor at the western end, where a schooner was sheltered behind the rocks, we did not wonder that Audubon's pilot was in doubt as to the opening of the "bowl," as he called it, or Hare Harbor, into which the Ripley finally blundered, for it was nowhere to be seen. The shore was bold and rocky with here and there a cove and pebbly beach. These beaches extend back into the land with or without intermissions of vegetation, green bands in the gray, - far up above the reach of any ordinary, or extraordinary, storm. These, of course, were examples of raised beaches, of which there are so many in Labrador, attesting the movement of the land in elevation. To Audubon they were a mystery; he writes: "On rambling about the shores of the numerous bays and inlets of this coast, you cannot but observe immense beds of round stones of all sizes, some of very large dimensions rolled side by side and piled one upon another many deep, cast there by some great force of nature. I have seen many such places and never without astonishment and awe. If those great boulders are brought from 
the bottom of the sea, and cast hundreds of yards on shore, this will give some idea of what a gale on the coast of Labrador can be, and what the force of the waves." In another place he says: "These stones I now think are probably brought on shore in the masses of ice during the winter storms. These icebergs, then melting and breaking up, leave these enormous pebble-shaped stones, from ten to one hundred feet deep."

When I landed my first pilgrimage was to one of these beaches. At the water's edge and for some yards back the beach pebbles, cobblestone size, were round and smooth, kept so by the wash of the waves and by grinding and polishing against one another. Higher up they lost their natural red color and were painted gray by the lichens; this color gradually merged into green as mosses replaced lichens, while, higher up still, spruces and firs, laurels, curlew-berry, Labrador-tea, and all the other low-growing arctic plants had thoroughly concealed the beach now raised fifty feet or more above the sea. It was interesting to notice a slight roughening of the surface of the rock on which the lichens were growing. 


\section{IN AUDUBON'S LABRADOR}

Higher up the surface crust for a quarter of an inch or so was soft and crumbling, while, where the vegetation was luxuriant, many of the pebbles had entirely lost their shape, and others were split into many pieces by the frost entering cracks wedged apart by plant-growth. In this way vegetation aided by frost changes even polished crystalline rocks into soil suitable for plant-food.

"You could not have happened in better weather," said the captain as the sea quieted down under the lee of the shore and we entered the mouth of the harbor, sailed through the narrows, and beat up to the head of the wonderful rock-enclosed bowl. The water was so deep that we were almost on shore before we could anchor. In this quiet harbor five or six schooners, Newfoundland fishermen, had taken refuge, but there were no signs of human habitation on the shore. It was as deserted as in Audubon's day.

As we had started early from Harrington, it was only half-past seven in the morning when we landed, and for five glorious hours we scrambled about the rocky mountains that surrounded the bowl. Heights are deceptive, 


\section{LITTLE MECATTINA AND MUTTON BAY}

and Audubon was so impressed by the scene that he exaggerated the height of the rocks. He says, "Our harbor is the very representative of the bottom of a large bowl, in the centre of which our vessel is now safely at anchor, surrounded by rocks fully a thousand feet high, and the wildest-looking place I ever was in." According to the chart, the highest peaks, a little way back from the harbor, have an elevation of five hundred and seventy feet, and it is probable that the rocky precipices that rise directly from the water reach a height of only two or three hundred feet. They are splendid rocks, however, and full of crannies and shelves. A pair of ravens were croaking and sailing about, and on the grassy beach at the head of the harbor four full-grown young were feeding. They were probably lineal descendants of the birds seen by Audubon. Above this beach a clear cold brook led from a lake, above which was a narrow forested valley, thick and impenetrable, in which I could hear the rushing of a brook. What unnumbered centuries it must have taken to make even a feeble grove on these adamantine rocks! A black-poll warbler was singing, 


\section{IN AUDUBON'S LABRADOR}

occasionally a yellow-bellied flycatcher ejaculated je-let, and a pipit on the Arctic borders of this Hudsonian island walked about and wagged his tail. Doubtless a ruby-crowned kinglet, as in Audubon's time, was concealed in the thicket, but he was silent; his season of wonderful song had passed. Above this valley was another lake and another summit beyond. From here there was an extensive view over a desolate region, or, in Audubon's words, "nothing but rocks - barren rocks - wild as the wildest of the Apennines everywhere." Rocky hills, lakes in islands, and islands in lakes. The red line of rock surface at the water's edge showed the salt-water inlet; the lichens and green plants extending to the water's edge showed the fresh-water lakes; otherwise they could not be distinguished.

Within fifty or seventy-five feet of the summit boulders, large and small, were lying about where they were left by the receding ice of the last glacial period; below that there were no poised boulders to be seen, they had all been washed into hollows by the waves during the period of submersion. The line between the two regions was sharply drawn. Profes- 


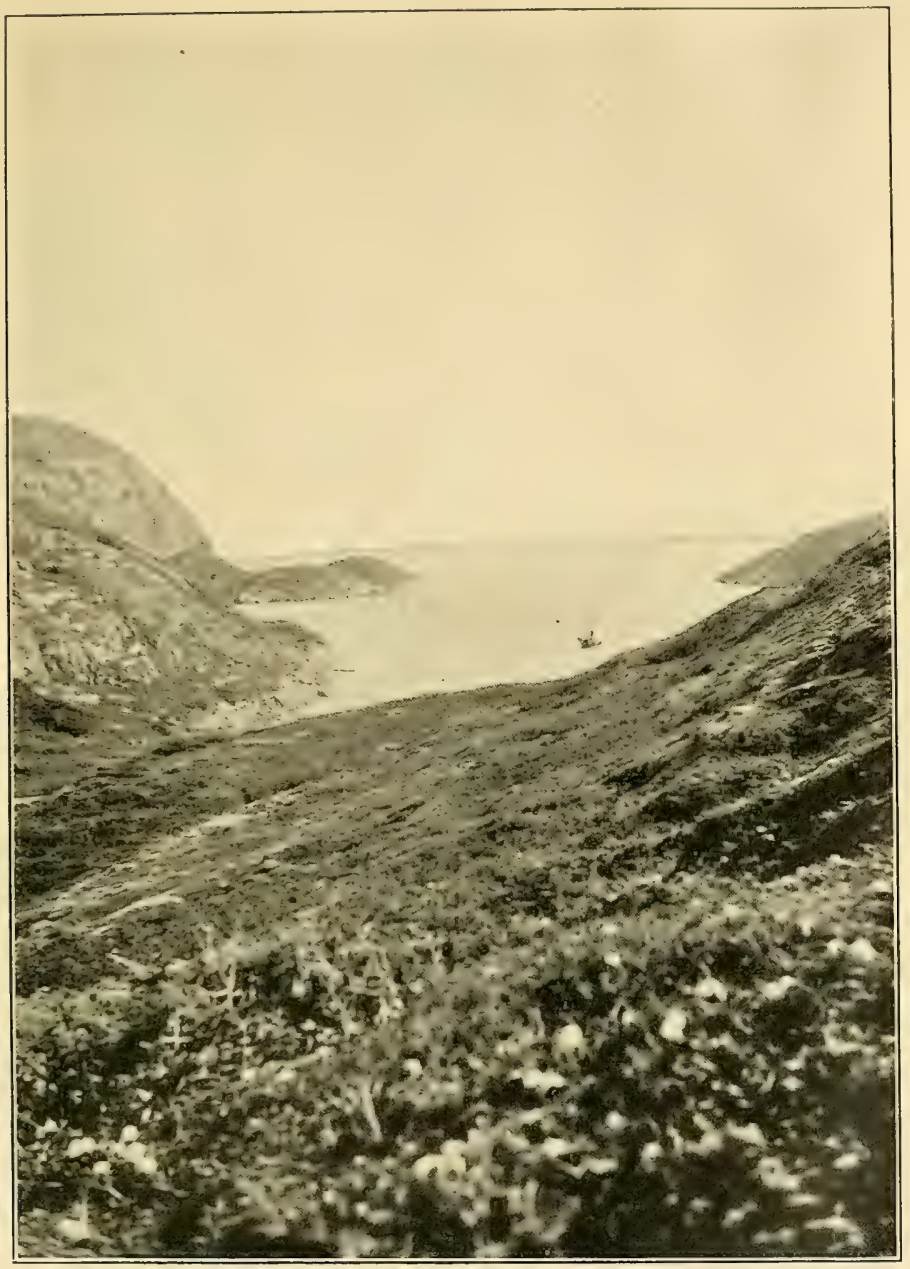

THE SEA STAR IN HARE HARBOR, LITTLE MECATTINA ISLAND 



\section{LITTLE MECATTINA AND MUTTON BAY}

sor Reginald Daly ${ }^{1}$ found at Ice Tickle, on the eastern Labrador coast, that poised boulders occurred only above the 265 -foot contour-line, while at Hopedale the highest shoreline was at 390 feet.

Many of the rock-surfaces at the summit were nearly as smooth and polished as when they were left by the ice, and they showed well the scratches and grooves made by the glaciers. These scratches radiate from the center of glaciation in the middle of the peninsula. I kept note of their compass direction in different places as I went east and found them to vary as regards true north from south $3^{\circ}$ west to south $35^{\circ}$ east. The variation of the compass at Natashquan is about $30^{\circ}$ to the west of north. I crossed a deep gorge on the tops of gnarled and twisted alders and spruces, a brook babbling unseen below me, and slid down steep slopes in the slippery mosses, as Audubon had done in the same place eighty-three years before. It was all good exercise and very exhilarating in the clear

1 The Geology of the Northeast Coast of Labrador, Bulletin Museum of Comparative Zoölogy, Harvard College, vol. xxxvili (I902), p. 255. 


\section{IN AUDUBON'S LABRADOR}

air, so cold that the captain had called for his mittens as he was beating up the harbor. A brief plunge into the sea and a quick scramble back removed all sense of fatigue.

Ernest was alone on board quietly cooking the dinner when something made him look out of the galley and he found that the Sea Star had dragged her anchor from the bottom into deeper water. He hastily let out more cable and prevented her putting to sea prematurely. When we did get off the sea was running high, lashed by a strong southwest wind, and we passed out of the harbor under a jib and reefed foresail for our thirty-three miles' run for Mutton Bay. We soon passed Île de la Providence, a smooth, red rock where a bleak, weather-beaten church stood out prominently on the ridge. This is the guiding star of the inhabitants, some fifteen or twenty families, who are scattered about in the archipelago of the Head of the Whale, Tête-da-laBaleine de Ouest. It is the Mission of St. Anne, formerly St. Magloire, and was built with much labor and sacrifice through the zeal of the Abbé Théberge in 1894. Huard says, "Bad weather, most furious winds, - 
nothing prevents the people, if only there is a priest to preside at the religious offices, coming with their wives and children in their fishing-boats to the Chapel. When they go au large for the fish or when they return, the sight of their chapel surmounted by its pretty tower fills them with joy." The island is so rocky that there is no soil in which those that die can be buried, and the cemetery is situated on the island of Kenty or the Tête à la Baleine, another smooth red rock which pushes out into the sea like a great whale's head. Huard quotes from the Abbé Gagnon, who says, "If the voyage to the isle of Kenty became impracticable, one must refrain from dying under penalty of being buried much later and almost without regret; this prospect suffices, it appears, to keep everybody alive." Another curious circumstance about this mission is that all of the inhabitants retire to their winter houses three miles inland after the fishingseason, and the greater part of the year must be spent, as in the case of the Indians, without spiritual succor. Father Hesry, of Long Point, Blanc Sablon, about one hundred and fifty miles to the eastward, is the spiritual 


\section{IN AUDUBON'S LABRADOR}

adviser for this little mission of St. Anne, and his visits are necessarily few.

The sheets of white foam ran rapidly up the smooth red sides of the whale's head, and - slowly sank back again as we drove on before the freshening wind. Foaming reefs appeared on all sides, but the captain knew them all and they had no terrors for us. A couple of fishing-schooners were sheltered close to the head and a half-dozen small houses clung precariously to its sides just above the water's edge. As we passed Nadeau Island, a round rock with a steep cliff, the captain pointed out the house of the man who had put by six thousand dollars in the bank, as a result of his lifework in fishing. Dying a bachelor, he had left this money - a fortune in these regions - to his nephew.

As the wind increased to half a gale we lowered our jib and, with only a reefed foresail, scudded across the intervening eight miles to Cape Mecattina. It was not exactly "under bare poles," but it came very near to it. Great green seas with white crests rose up behind us as if about to engulf our little schooner and surged along beside us, but the Sea Star, under 
the skillful management of Captain Joncas, rode them like a duck and kept her decks dry. Not only were the waves and the wind behind us, but also the sun, and, when the waves shut out its direct rays, the clear, transparent water sparkled with a wonderful green brilliancy. All too soon we reached Cape Mecattina with its rocky heights patched in places with snow, and passed into the shelter of Mutton Bay. This prosaically named place was the Baie de Portage - so called on account of an ancient Indian portage - into which Audubon in the Ripley entered on July 2I, I833. We were three days ahead of him in the calendar, and, while the Ripley, before "a stiff northwest breeze," had sailed from the harbor at Little Mecattina Island in five hours, we had scudded across in three. It seems too bad to race with Audubon, but I think he would have enjoyed it. I know Ingalls and Shattuck and Tom Lincoln and Coolidge and young John Woodhouse would have considered it great larks!

The derivation of the present name of the bay is uncertain, as there are no sheep there and probably never have been. The botanist suggested that it might have been named from 


\section{IN AUDUBON'S LABRADOR}

the fleecy aspect of the waves and their choppy character. I dare say some sea-captain presented another with a leg of mutton here, and the bay was named for this important and savory happening.

Under a protecting cliff, over which tumbled a waterfall that, like the Staubbach in the valley of Lauterbrunnen, was blown into dust and spray, lay the little village of Mutton Bay. There are about twenty families here, all, with one or two exceptions, Protestants from Newfoundland. The houses are of all colors, - yellow, pink, lilac, brown, and red, - and there is a Church of England chapel. Huard says the inhabitants desire to make the place the capital of southern Labrador, and that the village, compared with the other villages of the coast, "est d'apparence vraiment coquette."

I was soon ashore and at the telegraphoffice, where I found my old friend M. Charles Vignot, of Natashquan. His little grandchild sat on my knee and sang very correctly, and with a charming French accent, "Old Black Joe." It served to dissipate the gloom caused by the bad war news that ticked over the telegraph. Near the top of the rocky pass close 164 


\section{LITTLE MECATTINA AND MUTTON BAY}

to the "Staubbach" the wind was blowing so strongly that I could scarcely stand against it. The captain afterwards remarked, "Still some wind left - we did not use it all." From the pass a large patch of snow beyond looked like a glacier creeping down the hillside. It was marked by a deep crevasse, and from under an arch at the lower end a brook issued. All vegetation was as dead as winter about it. We were catching up with the spring as we went east and north. 


\section{CHAPTER VIII}

THROUGH THE PETITE RIGOLET TO THE ST. AUGUSTINE RIVER

N July 22, 1833, Audubon went in a small boat from Baie de Portage, where the Ripley lay at anchor, to a harbor a mile to the eastward, where an island shut off the sea to the south, and high hills kept off the northern winds. Here he found a French Canadian, a seal-catcher, who entertained him with an account of his work in netting seals, trapping foxes, and shooting bears, wolves, and caribou. This was Big Mecattina Harbor, and Audubon says in his "Episode" on "The Squatters of Labrador": "Pierre Jean-Baptiste Michaux had resided in that part of the world for upwards of ten years. He had run away from the fishing-smack that had brought him from his fair native land, and expected to become rich some day by the sale of the furs, Seal-skins, eider-down, and other articles, which he collected yearly, and sold to the traders who regularly visited his dreary abode. 


\section{THROUGH THE PETITE RIGOLET}

He was of moderate stature, firmly framed, and as active as a Wild Cat. He told that excepting the loss of his rum, he had never experienced any other cause of sorrow, and that he felt as 'happy as a lord." "

His grandson, Leander Michaux, or Michel, as it was given to me, the son of François, a man of seventy years, still lives there, and we waved our hands to him as we sailed by. In a little graveyard on the hillside Audubon's friend lies buried. There is but little change in the surroundings, the same work goes on, but there is less animal life of all sorts than in Audubon's day.

We sailed on over an emerald ocean of such clarity that we could see the bottom in several fathoms' depth. Five miles ahead of us to the right lay Great Mecattina Island looming up dark and forbidding in the early morning shadows. On our left we passed a bold, rocky. shore into which entered a deep bay - La Baie Rouge de la Tabatière. Why it should be called a snuff-box is rather a puzzle, but, according to Mgr. Bossé, ${ }^{1}$ the name should be Tabaquen, or Tapatienne, which, in Montagnais

${ }^{1}$ Annales de la Propagation de la Foi (Quebec, 1887), p. 207. 


\section{IN AUDUBON'S LABRADOR}

language, signifies sorcerer. At this point the Indians before departure for the interior came to consult the soothsayers to learn of their coming fortune in the chase. Deep in the valley, against a background of sheltered and sheltering spruces, was the church. Its altar is adorned by the skin of a polar bear shot here one winter a few years ago. Near at hand on the point - the old post - were a half-dozen houses.

"July 23, I833. We visited to-day the Seal establishment of a Scotchman, Samuel Robertson, situated on what he calls Sparr Point, about six miles east of our anchorage [Baie de Portage]." I quote from Audubon's Journal. On July 20, 19I5, we dropped anchor at Sparr Point in the well-protected harbor of $\mathrm{La}$ Tabatière. On the rocks at the entrance were capstans for seal-nets, as the seal establishment was still there. Almost no seals were caught last year, but the year before five or six hundred were secured. We were soon ashore at the fish-stage, for cod as well as seals constitute the harvest here, and, walking up through the multitude of Eskimo dogs, we were greeted by Samuel Robertson, not the 


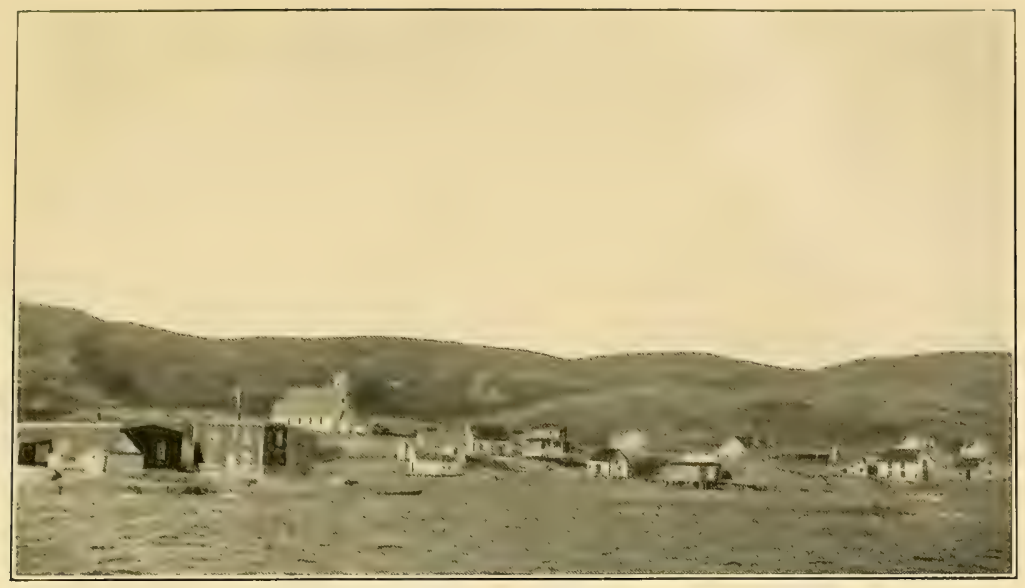

MUTTON BAY (BAIE DE PORTAGE)

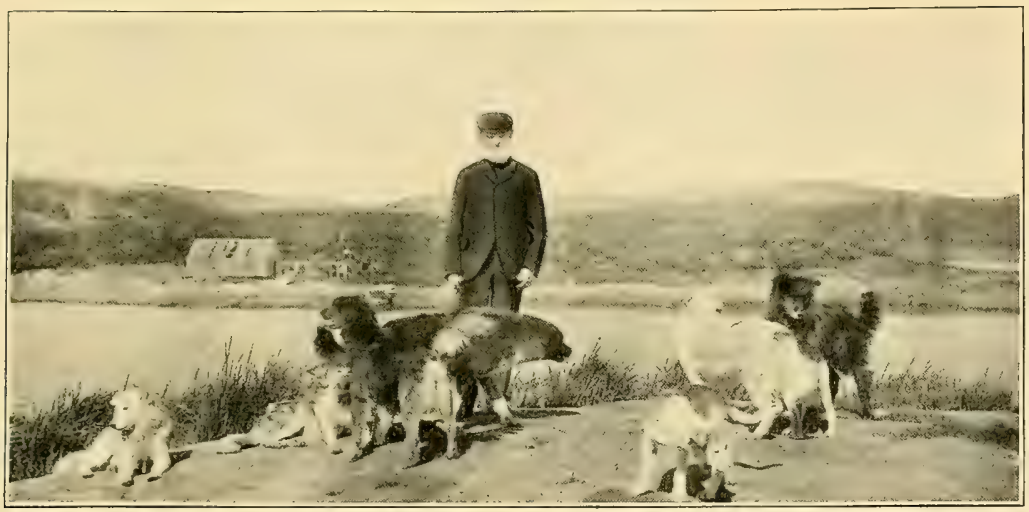

SAMUEL ROBERTSON, 3D, AND SOME OF HIS DOGS, AT SPARR POINT 



\section{THROUGH THE PETITE RIGOLET}

Scotchman of Audubon's day, but his grandson. The house was as neat as a pin, and its tall clock, a ship's barometer, and various ancient weapons, as well as thrifty windowplants, gave it an interesting and attractive look. While I was waiting for the old man to put on his best clothes, - for his wife would not hear of his being photographed in anything else, - the dogs, about twenty-five of them, engaged in a sudden fight. The uproar was quickly stopped by a buxom, rosy-cheeked lass who rushed out, seized a stick, and belabored them left and right with a hearty good-will. A dog was killed here in a fight a short time ago and good Eskimo dogs are too valuable to throw away. Audubon records that Samuel the First had more than forty of these animals.

Mr. Robertson soon returned our call, and I had the great pleasure of reading to him from Audubon's Journal about his grandfather. The Abbé Ferland, in writing of this same enterprising Scotchman, said that he attempted to catch whales in nets made with cables stretched between islands, but with the same success as if he had tried to catch caribou in 


\section{IN AUDUBON'S LABRADOR}

spiders' webs. Nowadays they use wire nets to catch submarines, so the Scotchman may not have been so far afield.

Audubon's account of his visit to Samuel Robertson, in the "Episode," is interesting. He says: "Several neat-looking houses enlivened the view, and on landing, we were kindly greeted with a polite welcome from a man who proved to be the owner of the establishment. For the rude simplicity of him of the rum-cask [Michaux] we found here the manners and dress of a man of the world. A handsome fur cap covered his dark brow, his clothes were similar to our own, and his demeanor was that of a gentleman. ... Having followed him to his neat and comfortable mansion, he introduced us to his wife and children. Of the latter there were six, all robust and rosy. The lady, although a native of the country, was of French extraction, handsome and sufficiently accomplished to make an excellent companion to a gentleman. ... Gazing on the desolate country around, I asked him how he had thus secluded himself from the world. For it he had no relish, and although he had received a liberal education, and had 


\section{THROUGH THE PETITE RIGOLET}

mixed with society, he never intended to return to it. 'The country around,' said he, 'is all my own, much farther than you can see. No fees, no lawyers, no taxes are here. I do pretty much as I choose. My means are ample through my own industry. These vessels come here for Seal-skins, Seal-oil, and salmon, and give me in return all the necessaries, and indeed comforts, of the life I love to follow; and what else could the world afford me?' I spoke of the education of his children. 'My wife and I teach them all that is useful for them to know, and is not that enough? My girls will marry their countrymen, my sons the daughters of my neighbors, and I hope all of them will live and die in the country!" "

After our exchange of calls with the representative of this interesting family, who had followed his grandfather's advice, we weighed anchor and continued our course on one of the most beautiful days of the summer. It is true that it was hardly summer heat, for the thermometer was $49^{\circ}$ in the morning, $57^{\circ}$ at noon, and $55^{\circ}$ at night, but the sun was bright, the air was clear, and a gentle northwest wind brought us the odor of balsam firs and the 


\section{IN AUDUBON'S LABRADOR}

songs of birds. The shadows of the clouds piled up over the high land of Great Mecattina were wonderfully beautiful. We sailed out past the Baie du Lac Salé, where the six brothers Gallichou, who live in summer at Old Post, have their winter houses; past $\mathrm{Ha} \mathrm{Ha} \mathrm{Bay} \mathrm{with} \mathrm{its}$ fine hills; past a deep harbor, formed by a glacial cirque, and on into the archipelago of Kekarpoui. The captain suggested that these islands would make a good bird reservation, but the birds had been so decimated there that the name of one of the groups of rocky islets - Les Îles Affigées - seemed most appropriate. Only a few black-backed gulls, razor-billed auks, and black guillemots were to be seen. Not an eider or murre was left, but I have no doubt that rigid protection would bring all of these birds back in numbers.

On one of the Kekarpoui Islands lived a Good Samaritan, an old salmon-fisherman, Jacques McKinnon. Whenever Jacques heard of any lonely body too old or infirm to work, he would take him to his house. $\mathrm{He}$ and his wife had ministered to several poor old derelicts who had had no one to care for them, and had tended them faithfully until death. 


\section{THROUGH THE PETITE RIGOLET}

There is a narrow passage between the islands close to the old man's house, and this, at low tide, the Sea Star negotiated under full sail. So intent was the captain on escaping the rocks in this intricate passage that he did not salute the Samaritan. Indeed, we hardly looked at him, for it was an exciting moment for all on board. Ernest cried, "Keep her up!" and William at the same time, "Keep her off!" but the captain heeded them not, and, from his long experience, was able to give the proper turns to the helm at the right moments, and the Sea Star glided through without a graze. The clear water showed our narrow escape from the rocks that beset us. It was a serious offense to sail by thus without paying any respects to the old man, who stood like a statue among his Eskimo dogs with his back against a rock. He was a picturesque figure with his white bushy beard. The captain chuckled at his success in making the difficult passage, and at the confusion of the two sailors. He would stop and make his peace with the Samaritan on his return.

When Audubon sailed from La Baie de Portage at five o'clock on the morning of July 26 , 


\section{IN AUDUBON'S LABRADOR}

he wished to see something of the intervening coast, but, as the pilot knew "nothing at all" of the harbors, they proceeded to Bradore Bay, where they came to anchor the next morning. He says his "mind was as troubled as the ocean" and that the coast is "crowded with islands of all sizes and forms, against which the raging waves break in a frightful manner." I could not but regret that such a man should have been hindered in his work by such a pilot. Our good captain sailed northeast straight in among the maze of islands, and, after a passage of five miles through a waterway a mile broad, turned east and entered the long passage between the islands and shore known as La Petite Rigolet. For eighteen miles this passage extends, and we sailed through it with a good wind astern. In places it was but a couple of hundred yards wide. One such place, the narrowest of all, is called Rapide Lessard, for here Madame Lessard, traveling in the winter on a dog-sledge, broke through the ice and was drowned; a cross on the rocks commemorates the tragedy. In other places long bays extended off to the right or left with deep valleys beyond, within whose sheltering 



\section{THROUGH THE PETITE RIGOLET}

walls birches and spruces and firs grew to a respectable size. The hills were white with reindeer moss and the rocks were dark and rugged; no signs of human hands were anywhere to be seen. A few great black-backed gulls scolded us as we passed, and three venturesome young ones swam out from a rocky island. A female eider occasionally flew ahead of us, and we passed one in a bay that seemed to have but one duckling in tow; the others were probably concealed. A raven croaked from some rocks and we occasionally heard the calls of white-crowned sparrows and blackpoll warblers, but aside from these there was little of bird-life. This long passage is in most places fifteen to thirty fathoms deep even close to the shore, and if we had wished to land it would have been necessary, instead of anchoring, to tie to the rocks or a tree.

Just before we emerged from this long canallike passage we passed a lone salmon-fisherman tending his nets. How many gulls and eiders and their eggs he had taken was not manifest, but it is to repeated and persistent depredations by his class that the approaching extinction of Labrador water-bird life is due. 


\section{IN AUDUBON'S LABRADOR}

Leaving the Rigolet, which seemed to close in behind us and be lost in the labyrinth of islands, we turned northwest by Grosse Ile and perceived in the distance beyond us the buildings of the Hudson's Bay Company's post at St. Augustine - buildings as white and trig as are all the outlying posts of this great company. We entered a big landlocked basin over five miles in diameter, an inland lake with rocky, semi-mountainous shores and no sign of an outlet. The story goes that a yachtmaster, who was piloted through the Rigolet to Bradore Bay, declined a pilot for the return, as he had taken numerous notes of directions and bearings, and he prided himself on his good memory for places. After trying for several days to find the eastern end of the Rigolet, entering innumerable blind passages and scraping various reefs, he gave it up and put to sea.

We dropped anchor that afternoon a few miles below the post in one of the captain's many favorite harbors where the boat was as quiet as if she had been on shore. A salmonfisherman and his wife and child and a crew of Eskimo dogs lived at the head of the har- 


\section{THROUGH THE PETITE RIGOLET}

bor. Their winter house - their habitation for nine or ten months - was at the post. We obtained a bucket of trout - two- and three-pounders - in exchange for the same measure of potatoes, and the botanist and I were off for a reconnaissance of this land unknown to men of our tastes and hobbies. We might have fished for trout, but the potatoes had accomplished our purpose quicker than artificial flies would have done, and both of us, although fond of fishing, were agreed that there is no greater sport for the naturalist than exploring an unknown region. We are still of this opinion even though the flies were so thick and active that existence was possible only with the head securely tied up in a bundle handkerchief. Comfort, in addition to existence, was given from time to time by timely application of citronella ointment to the small exposed area of face.

I spent some time at a lake among the hills watching two broods of golden-eye ducks with their mothers. One brood of five were taking life easily as they floated about and preened their miniature wings and still more diminutive tails. They paid no attention to me; they 


\section{IN AUDUBON'S LABRADOR}

had not learned to be afraid of man. The mother soon appeared swimming leisurely around a point, but, as soon as she caught sight of the human intruder, she uttered a warning note and rapidly swam away. Later, when I came upon this same brood, they were no longer unsophisticated, but dived at once and made off. They had been warned that I was dangerous.

The St. Augustine River is one of the great migration-routes of the Montagnais Indians. By its waters and those of other rivers and lakes with the intervening portage-paths long traveled by the Indians, it is possible to cross the height of land and reach the shores of Hamilton Inlet and the North-West River Post. I was told that a Catholic priest with two Indians had reached the mouth of the St. Augustine River after nine days' travel from the North-West River Post. Indians with their families make the trip in fifteen days. Beckles Willson, in his "Life of Lord Strathcona and Mount Royal," says of this great man, - then plain Donald Alexander Smith: "At the end of April, I848, a couple of guides and a canoe were procured, and he ascended 


\section{THROUGH THE PETITE RIGOLET}

the St. Augustine River. After three weeks' travel he struck into the Grand River, crossed Goose Bay, and duly reported himself to Chief Trader William Nourse at North-West River, at that time the chief of the Labrador posts of the Company."

Twice a year, as at Seven Islands, Mingan, Natashquan, and Romaine, the Indians and their families traverse the route to and from the coast. They go in in the fall and come out in the spring with their furs. They have done it since babyhood and their ancestors for unnumbered generations before them. What wonder is it that they know the way and the best and easiest way? The white man who attempts the route without the Indians' guidance is severely handicapped and makes a failure of it. I learned this in I9I 2 on the Natashquan River. ${ }^{1}$ In I 890 a Canadian, Mr. J. G. Alwyn Creighton, ascended the St. Augustine River, hoping to cross the height of land to the Hamilton River. Insubordination of his Indian guides and a great forest fire

${ }_{1}$ A Short Trip into the Labrador Peninsula by Way of the Natashquan River, Bulletin of the Geographical Society of Philadelphia, vol. XI (I913), pp. 38-50. 


\section{IN AUDUBON'S LABRADOR}

caused him to turn back. In I9I2 Mr. Henry G. Bryant, ${ }^{1}$ of Philadelphia, one of the few white men who has seen the Grand Falls of the Hamilton River, attempted the traverse of this part of the peninsula by way of the St. Augustine River. He and his companion, $\mathrm{Mr}$. Russell W. Porter, had provided themselves with experienced canoe-men, but they especially desired to obtain Indian guides to insure the success of the expedition. "Aside from the usual disinclination of the Indians to engage in systematic labor," he says, "we soon learned that the most serious obstacle arose from their unwillingness to have white men spy into the secrets of their country." They had no desire for timber mills or mining camps in their hunting grounds, and they are not to be blamed. At last, with the help of Père Hesry, two young Indians were obtained who agreed for five dollars a day apiece to guide the party as far as the height of land. The expedition started in three canoes on the I2th of July. The Indians kept ahead out of sight in their lightly laden canoe, and appeared only

1 An Exploration in Southeastern Labrador, Bulletin of the Geographical Society of Philadelphia, vol. XI (19I3), pp. I-I5. 


\section{THROUGH THE PETITE RIGOLET}

at meal-times, when their appetites were phenomenal. On the fourth day, however, the Indians left them, and Mr. Bryant had to get on without them as best he might. They had a rough and difficult time, a succession of rapids in the river with portages by the dangerous places. One of the portages was ten miles long. After nearly a month's travel the expedition reached the source of the river one hundred and sixty miles from the sea, and stood at the foot of the well-worn Indian portage up over the height of land. Ten days more would doubtless have brought them to the Hamilton River, but one of the canoe-men had so wrenched his knee that Bryant did not feel justified in proceeding, and with heavy hearts they were obliged to give up the undertaking and return. They reached the post at the mouth of the river on August 23.

We had enjoyed our day but were glad to creep into our sleeping-bags long before the light had failed. In the east that evening there was a small piece of rainbow. The captain called it "the eye of the buck" and said it betokened wind from the same quarter in the morning. He was right. 


\section{CHAPTER IX}

\section{SHECATICA AND JACQUES CARTIER}

TNSTEAD of going up the broad river to 1 the post, a passage beset with shifting sandbars, we set sail for Sandy Isle, or Île Bayfield, as we hoped to find the Indians there. It was like sailing through a large lake dotted with islands, for there was no sight of the sea. The captain said that thirty or forty years ago this region was filled with eiders that nested on all the shores. Constant persecution by the Indians and fishermen, who take all the eggs and shoot the nesting birds, has produced deplorable results, for, with the exception of one flock of nineteen migrating to the eastward, no eiders were to be seen. A few fishermen and their families live at the St. Augustine Post in winter, but are scattered among the islands in summer, and are fast destroying the birds. A few gulls and sea-pigeons alone survive.

I We landed on one of the islands, where the men gathered a plentiful supply of driftwood 


\section{SHECATICA AND JACQUES CARTIER}

brought down by the great river. The shore was fringed with strand wheat heavily loaded with the fruiting spikes, the hills were white with reindeer moss and dotted with bakeapple and mountain cranberries, and in the valleys dwarfed and distorted forest trees struggled for life.

Three hours later, after a reconnaissance not merely ornithological and botanical, - as I here added considerably to my collection of spiders for Mr. Emerton, - we again set sail in the "lake" with its many islands and deep bays. We passed a rock that the captain said was formerly visible above water only at spring tides, but that now emerged at every tide. Near Paul Nadeau's Island we opened up the Grand Rigolet, and also for the first time saw the sea through a narrow gap.

It had been an active morning for all of us and the captain called out, as was his custom, "Cook, cook, avez-vous des bonnes nouvelles?" Not long after, a loud knocking in the galley, repeated in a few seconds, announced the good news. Capelin, hot on the stove and ready at hand, juicy seal-steaks, potatoes, and boiled 


\section{IN AUDUBON'S LABRADOR}

tender tips of beach peas, with an admirable grain rouge pie, were all good and proved that the cook was not a false prophet.

We arrived at our anchorage at Sandy Isle only to find that the Indians were not there. Sandy Isle derives its name from the elevated bluffs of marine sand similar to those at various other places on the coast. Some of the ponds in the tundra had hard beaches of fine sand on which it was a pleasure to walk after struggling through the deep and spongy bog. A robin sang in a deep ravine bounded by black cliffs as cheerfully as if he had been singing in an orchard or among the swaying branches of an elm in a village street. Whitecrowned and white-throated sparrows compared notes, and a fox sparrow was in very good form considering the lateness of the season. In a reedy pool I came upon a black duck that fluttered and flapped her wings as if she were sore wounded. That it was mere pretense to lead me away from her young hidden in the reeds, I made sure, because, as I continued to draw near, she took to her wings and flew a few yards. Again she performed the woundedbird act, but this time it was on the land and 



\section{SHECATICA AND JACQUES CARTIER}

I could plainly see that she was not of the red-legged subspecies which breeds still farther north, but the sad bird - Anas rubripes tristis - of my friend Brewster.

But it was not all sand and moss and water here, for there were smooth granitic ledges on the shore, on some of which I found and photographed the interesting glacial markings known as "lunoid furrows." I had previously noticed them at Natashquan, at Grand Romaine, and at Little Mecattina. These markings were transverse to the direction of glaciation as shown by the grooves, and varied from a few inches to a foot or more long and extended about an inch into the rock. As their name indicates, they are crescentic in shape, and the convexities of the curves point in the direction from which the glacier came. They suggest that the ice or graving tool had caught and hitched along, tearing out the rock. Professor R. A. Daly, in his paper on "The Geology of the Northeast Coast of Labrador," says: "From a somewhat prolonged study of the typical examples at Hopedale, the writer was led to believe that these lunes were only potential when the ice-sheet disappeared... 


\section{IN AUDUBON'S LABRADOR}

The tension or shearing stress set up in the bed-rock by a boulder dragged along beneath the ice, must oftentimes be enormous.... The integrity of the rock-surface will henceforth be endangered because frost can work upon these cracks in the same manner as it works on joint-planes. The actual hollows would thus owe their existence to the postglacial splitting action of frost, prying up and breaking off prismatic fragments of the rock until these fragments had reached a thickness appropriate to the steep inner face of the lune."

From our anchorage in the harbor the two or three houses at the bleak point looked forlorn and desolate enough; there was nothing lovely or beautiful about them until the setting sun disguised their shabbiness and glorified the whole landscape. As the sun went down behind low-lying black clouds, the sky in the east was gradually eclipsed by the shadow of the land and became the darkest of blue. This color was well set off by the vivid Venetian-red sail of a fishing-boat whose occupants were returning from their day's labors. The sea itself was vinaceous in color with a dull metallic cast. Above the eastern eclipse were 


\section{SHECATICA AND JACQUES CARTIER}

layers upon layers of purple and pink clouds against a blue background, while a veil of gray mackerel clouds covered the apex of the vault of the heavens. To the northwest, above the cloud-bank where the sun was hidden, was a clear light-blue sky in which floated fleecy clouds whose colors constantly changed from rose-pink to dark maroon. The weatherbeaten houses, the grim, hungry shores, the heaving sea, and fathomless vault of heaven were all transformed and enriched in the glorious luminous glow. It is Benson who speaks of a wonderful sunset in its effect on himself as an experience wholly and deeply religious: "And here I am but recording my own experience when I say that the lights and gleams of sunset, its golden inlets and cloud-ripples, the dusky veil it weaves about the world, is for my own spirit the solemnity which effects for me what I believe that the mass effects for the devoted Catholic - the unfolding in hints and symbols of the mysteries of God." In another place he says, "But there are some idealists who find the sense of worship and the consciousness of an immortal power... in the endless loveliness of nature, her seas and streams, her 


\section{IN AUDUBON'S LABRADOR}

hills and woods." And the most impressive of all nature's manifestations is the sunset.

We cruised the next morning among islands formerly crowded with sea-birds, but it was the same story: the fishermen had cleaned them all off. A few gulls and sea-pigeons alone eked out a perilous existence. The coming of the gasoline motor-boat, which has made travel among the islands so easy in the last two years, had put the finishing touch on these nurseries of bird-life. We passed Tommy Le Salt Shoals, now known as Grenfell Shoals, for Dr. Grenfell was the last to run on them, in the Strathcona. Leaving Duke's Island on our port, we sailed across the entrance to Cumberland Harbor, passed the great rocky point of Cumberland Head, rising sheer from the water, and entered Shecatica Bay. Near the entrance on the left, nearly concealed behind the rocks, was a fisherman's house, and the flag of the fishing-firm of Job Brothers and Company, Limited, - a white square on a blue ground, -- was flying close by. Shecatica Bay is a splendid broad bay embosomed in rocky hills, with a great open basin to the west and many islands on the eastern side. The only 


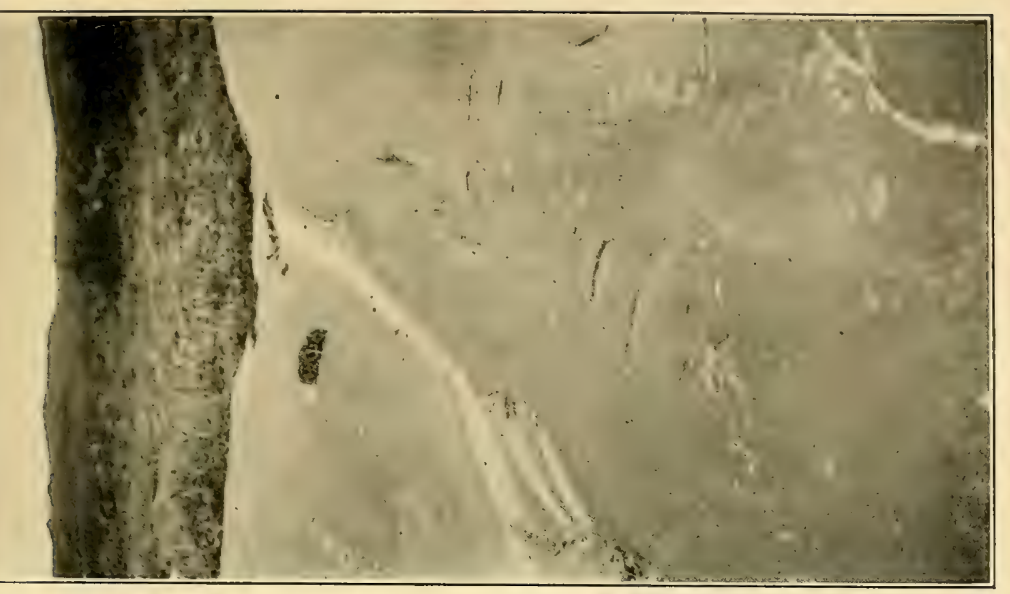

是

20

50

도 I

ㅇํㅇ

Z

$=$

岁

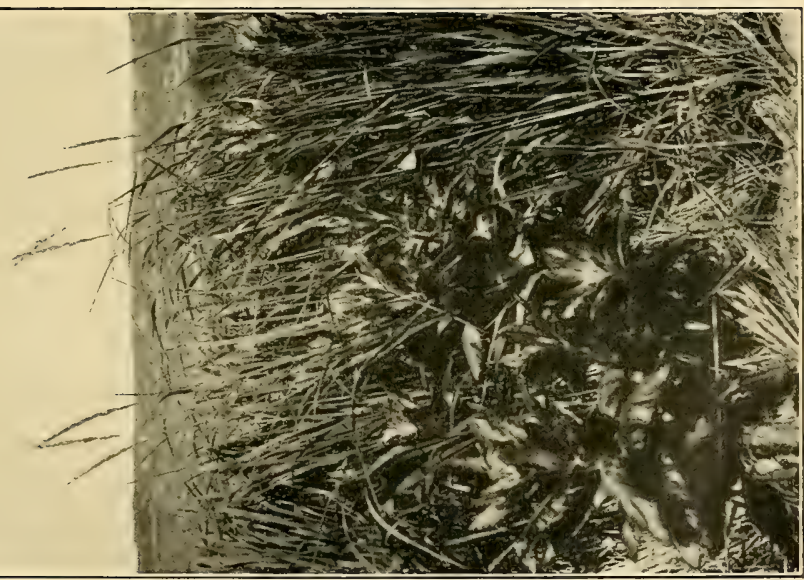

党 

house in the whole bay is the substantial one in the northwest corner belonging to the telegraph-operator, Mr. Louis Robin. At the head of the bay we entered what seemed to be a narrow rapid river, and, sailing close to the rocky shore, began our voyage up Shecatica Inlet. I am inclined to agree with Professor W. F. Ganong ${ }^{1}$ that this inlet is probably that to which Jacques Cartier refers as the St. James River, and that the harbor he named after himself is in reality Cumberland Harbor. Any one who has entered Shecatica Inlet, or merely passed its mouth, might easily mistake it for a river. The generally accepted view, however, is that Shecatica Inlet is Jacques Cartier's Harbor and it is so designated on maps. Ganong does not accept the idea, which at first sight seems plausible, that the name Shecatica, or Shekatika, is an Indian corruption of Jacques Cartier. Lemoine's Dictionnaire Français-Montagnais - which, however, is not infallible - says that the word comes from shikatikau, and signifies, "there are bushes around the water."

1 Jacques Cartier's First Voyage, Transactions Royal Society of Canada, sec. II (I887), pp. I2I-36. 


\section{IN AUDUBON'S LABRADOR}

Jacques Cartier on his first voyage left his native town, Saint-Malo, France, on April 20, 1534. His first landfall was Bonavista, Newfoundland, and after visiting Funk Island and provisioning with the great auks - think of the sacrilege! - he entered the Straits of Belle Isle and sailed along the southern Labrador coast to Blanc Sablon. From the latter place he sailed to the Port of Brest and then to Jacques Cartier's Harbor, but on June I3 returned to Brest. He was so impressed with the number of islands along this coast that he named the locality "Toutes Îles." From Brest he sailed to the west coast of Newfoundland, and thence to the Magdalen Islands, Prince Edward Island, the Bay of Chaleur, Gaspé, and Anticosti, and he finally crossed back to Canadian Labrador somewhere near Long Point, Mingan. Owing to the lateness of the season he decided to return, and, passing Natashquan Point, which he named Cape Thiennot after the Indian chief there, he reached Blanc Sablon on August 9 and Saint-Malo on September 5 .

The original description of these discoveries was published in Rouen in I 598 under the title, 


\section{SHECATICA AND JACQUES CARTIER}

"Discovrs du Voyage fait par le Capitaine Iaques Cartier aux Terres-neufes de Canadas, Norembergue, Hochelage, Labrador, et pays adiacens, dite nouuelle France, auec particulieres mœurs, langage, et ceremonies des habitans d'icelle."

The book was republished in Paris in 1863 , and from this I quote the parts about the River S. Jacques and the Port of Jacques Cartier. The whole book is very quaint and full of interest:-

"Plus outre à deux lieuës, y a vn autre bon fleuue plus grand, auquel nous peschasmes beaucoup de Saumons, et l'appellasmes le fleuue de S. Iacqves: . . . Nous mismes ensemble en vn autre port, qui est plus vers Ouest, viron une lieuë plus outre que le susdit fleuue de $\mathrm{S}$. Iacqves, lequel i'estime estre vn des meilleurs ports du monde, et fut appellé le port de Iacqves Cartier. Si la terre correspondoit à la bonté des ports, ce seroit vn grand bien, mais on ne la doit point appeller terre, ains plustost cailloux et rochers sauvages, et lieux propres aux bestes farouches: d'autant qu'en toute la terre deuers le Nord, ie n'y vis pas tant de terre, qu'il en pourroit en vn benneau. 


\section{IN AUDUBON'S LABRADOR}

... Et en somme ie pense que ceste terre est celle que Dieu donna à Cain." 1

After we had passed the rapid at the outlet of Shecatica Inlet, the shores widened and we sailed as in a rock-bound lake surrounded by miniature mountains. Little brooks glided tranquilly down over smooth rocks or tumbled and boiled out of chasms. There were small sandy beaches and pockets of forests in protected gullies. Again the water narrowed ahead of us and we entered the "second rapids" to emerge into another and larger basin over two miles in diameter.

"The mountains opened wide on either hand, And lo! amid those labyrinths of stone The sea had got entangled in the land, And turned and twisted, struggling to get free, And be once more the immeasurable sea."

1 "Two leagues farther on there is another good river still larger, in which we caught a great many salmon, and we called it the St. James River: . . . We put into another harbor farther west and about a league beyond the aforesaid St. James River, which I judge to be one of the best harbors in the world, and which was named Jacques Cartier Harbor. If the land corresponded to the excellence of the harbors, it would be a great blessing, but one ought not to call it land at all, but rather pebbles and savage rocks and places fit for wild beasts, inasmuch as in all the land towards the north I saw not so much as a cartload of earth. ... And, in fine, I think that land is the land that God gave to Cain." 


\section{SHECATICA AND JACQUES CARTIER}

Here the forest was larger and more extensive, filling in great valleys between the rugged precipitous hills. We passed a long sand-beach and the mouth of the Little Coxipi River, and, turning abruptly to the northeast by a high rocky island or peninsula, entered a lovely basin.

All the valleys were heavily forested and the tree-line on the hills was higher than at the entrance of the inlet. Near the delta of the Little Shecatica River, whose falls we could hear roaring in the forest, we at last found an anchorage. Elsewhere our plumb-line had not reached bottom - it was twenty or even thirty fathoms deep. We had sailed eight or nine miles from the entrance of Shecatica Bay to the foot of the inlet at the first rapid, and ten or twelve miles from there to our anchorage at the head of the inlet. We had come from the Arctic Zone with trees flat on the ground to the Hudsonian Zone of spruce and fir trees fifteen or twenty feet high. Here and there a giant black spruce, bare for the most part with a tuft of dark foliage on its summit, towered ten or fifteen feet higher. The Arctic Zone was still here, however, for the hills, which reached 


\section{IN AUDUBON'S LABRADOR}

a height of five or six hundred feet, extended their rocky and lichen-covered summits above the tree-line. It was a beautiful place, and it was a great pleasure to gaze upon the scene from the deck of our little schooner, where the gentle breeze served to keep away the insect pests. But the naturalists, like eager children, would not be satisfied until they could examine at close range all the interests of the place.

At the mouth of the Little Shecatica River we found a tent and a hogshead in which to salt salmon, but no sign of recent occupancy. An old Indian portage leads up to the rapids and falls of the river, twisting its narrow path through the forest. The roar of the river drowned out all the bird-voices, and I pushed on, enjoying from time to time the glimpses of falls and rapids, and at last reached a small forest-embosomed lake where the portage-path ended abruptly. As I had not carried a canoe on my head to launch into the lake, I had no choice but to take to the forest, guiding my way by the sound of the river behind and the glimpses of a precipitous peak in front. On the way I came upon a family of water-thrushes. They appeared somewhat darker than the 


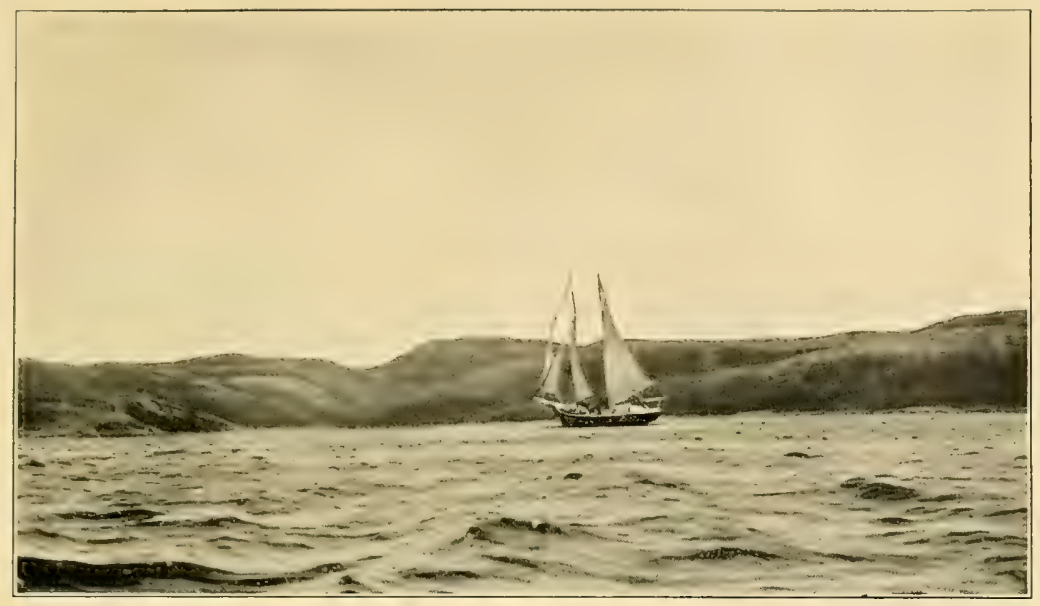

THE SEA STAR IN SHECATICA INLET



SHECATICA RIVER 



\section{SHECATICA AND JACQUES CARTIER}

bird of northern New England, but their ways were familiar. From the peak I could see four little lakes or basins connected with rapids and falls that flashed out white among the spruces. Another peak much higher, to the westward, then became my goal, and, after a struggle through the thick woods and thicker flies, I reached its summit and was well repaid by the glorious view over a typical southern Labrador country, bare and desolate in the uplands, but thickly forested in the valleys. In the little salt lake, perhaps six hundred feet lower down and to the south, the Sea Star looked like a speck on the unruffled water. Other lakes not so freely connected with the sea lay to the north and west. Arctic birds, pipits and horned larks, alighted and walked on the poised boulders of the summit of my little mountain, and white-crowned sparrows called and sang in the scrubby thickets lower down. It would have been easy to retrace my steps and thus find my way back to the schooner, but a steep and narrow valley to the west which evidently concealed a brook flowing down to the inlet tempted me to return in this way. One can have no better guide than 


\section{IN AUDUBON'S LABRADOR}

a brook; it is sure to flow into a river or lake or sea.

\section{"And even the weariest river Winds somewhere safe to sea."}

It is a friendly companion with a soothing, cheerful voice, and, although difficult at times to follow, is a safe guide. It was Plautus who said: "He who knows not the way leading to the sea, should make the river his companion." A soap-down on deck and a plunge in the inlet soon dispelled all feelings of irritation from the flies and of heat and weariness.

The next day we sailed only a mile on our return and were glad the wind gave out and compelled us to anchor, for we could well spend another day ashore. How glad we were that we had no vile gasoline motor! This anchorage was at the delta of the Little Coxipi River, and about a quarter of a mile to the westward of this we found the beginning of the Grand Portage. This is a portage-path that the moccasined feet of the Montagnais Indians, men, women, and children, have worn and polished for generations. With their canoes and supplies and household gods on their backs, with their babies and spoils of 


\section{SHECATICA AND JACQUES CARTIER}

the forest, they have journeyed back and forth for centuries. Many tons of furs have been brought by this portage, which leads over the hills and by little lakes to the Big Coxipi River, then by a series of lakes and portages to the St. Paul River, and so on over the height of land to Hamilton Inlet.

One not familiar with Indian portage-paths might picture a broad, smooth path, almost a road, over the mountains and through the forest, as a result of such long usage. This is not the case, however, for the portage is but a narrow footpath in which men may walk in single file, a path that winds and twists to avoid obstacles, some of which, like fallen trees, may have long since disappeared. A portage-path well suits the purposes of an ornithologist, for in it he may cover large areas of country without the necessity of struggling through the thick growths except for short forays on either side, and he has no need of watching his direction lest he be lost. Its superiority was well shown that morning when I stumbled upon the portage and went a couple of miles into the interior, while the botanist, not finding it near the Little Coxipi 
River as he expected, was unable to penetrate into the thick tangle more than a couple of hundred yards.

The foot of the Grand Portage at the inlet was crossed by a narrow brook of the clearest, coolest water, and I drank where doubtless many Indians had drunk before me. The path led up over steep rocks to an elevated plateau from which there was a good view of the forest below and the inlet. Here I found a campingground marked by the circles where a dozen or more wigwams had stood, still carpeted with balsam boughs now leafless. In the center of each circle short stakes had been driven into the ground. On these a little sheet-iron stove had stood, a more convenient form of family hearth than the old open fire. The smoke from the stove is conducted out through a small iron pipe. I searched about this campsite and found the broken stock of a cheap Hudson's Bay Company's gun, a single caribou antler chipped with a knife, gulls' and ducks' feathers, and long shavings and props where canoes were built. A singular wooden implement shaped like a large wooden dumbbell puzzled me, but I afterwards learned that 


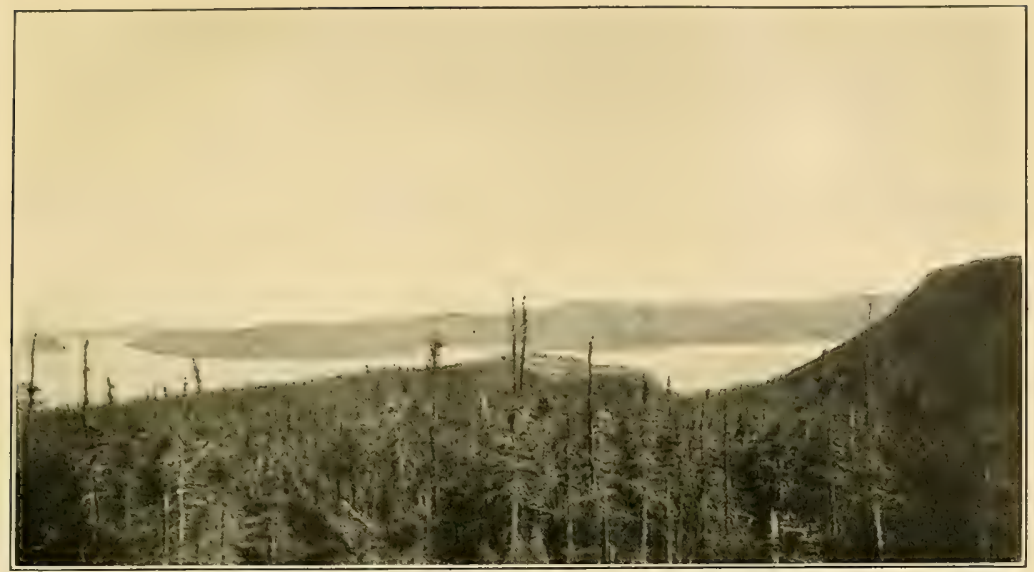

LOOKING DOTN SHECATICA INLET FROM THE GRAND PORTAGE

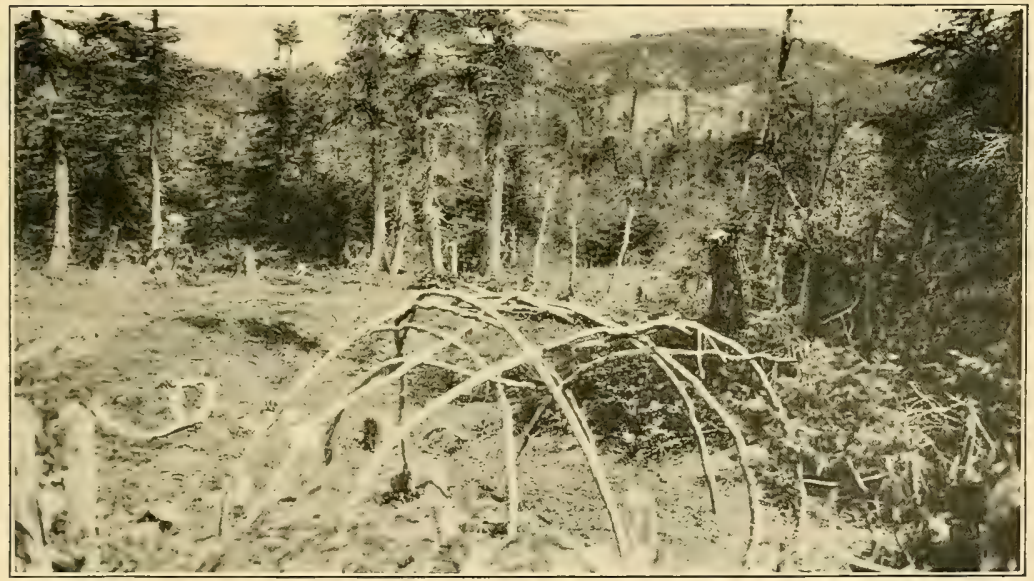

FRAMEWORK OF SWEAT-HOUSE AT INDIAN CAMPING-PLACE ON THE GRAND PORTAGE 

it was used in building canoes, in pounding the ribs from within alternately, first on one side and then on the other. It goes by the simple name of vateragamashook. But the most interesting record left in this Indian encampment was the framework of a low oval wigwam formed of twelve poles bent over and tied with withes. It was five by six feet in diameter and four feet high. In the middle was a flat surface of sand surrounded by a circle of sphagnum moss. Here were chips of stone and bits of charcoal, while outside were numerous large stones which showed the effects of fire. This was a sweat-house where the Indians took a Turkish bath. It is an almost universal practice among them. The "Handbook of North American Indians," published by the Smithsonian Institution, says: "The type of the ordinary sweat-house seems to have been everywhere the same. Willow rods or other pliant stems were stuck into the ground and bent and fastened with withes into a hemispherical or oblong framework, which generally was large enough to accommodate several persons. A hole was dug conveniently near the door into which stones, 


\section{IN AUDUBON'S LABRADOR}

usually heated outside, were dropped by means of forked sticks. These were sprinkled with water to generate steam. A temporary covering of blankets or skins made the enclosure tight. . . The construction of a sweat-house was usually attended with many rules and observances. ... A Among the Kiowa (Mooney) the framework consisted always of twelve supports." It is interesting to note that there were just twelve supports in this sweat-house. The sweat-bath has been used among the Indians as a religious rite, as a treatment for disease, and as a social and hygienic practice. Hovering about the camp, probably with a view to food, was a Labrador jay, the darker race of the Canada jay or whisky-jack.

The portage-path led up over an old seabeach perhaps two hundred feet above sealevel, made up of rounded cobbles and pebbles more or less disintegrated by the vegetable growth and frost. The rocky heights at the same level were bare of boulders, but those two or three hundred feet higher showed delicately poised boulders against the sky-line. On one of these I counted fourteen large ones. The view to the south gave a glimpse of the 200 


\section{SHECATICA AND JACQUES CARTIER}

sea through the lower passage of the inlet, with wonderful patches of blue water among rocky hills, while to the northwest was a large lake. I followed down the portage-path on the other side of the divide until it entered a sparsely forested bog and ended at a small narrow lake shut in on the east by rocky cliffs.

The botanist and I had interesting experiences; our short incursion into the partially forested interior from the barren coast was a profitable one. He added twenty species to his list and I four to mine. There are thrills to be experienced in the pursuit of all hobbies. I expected a great many thrills in Audubon's Labrador and I had my full share. Now this kind of thrill may be produced by any unusual thing in the ornithological world and may range from the first sight of a common bird on its arrival in the spring to the discovery of a bird new to science. It includes, for example, the observation of a rare bird or of an unusual or unknown song or note or habit. Thrills of this sort add greatly to the pleasures of life, and only those who have experienced them know their full value.

My greatest thrill was here, at Shecatica, 201 


\section{IN AUDUBON'S LABRADOR}

over a small and insignificant-looking bird, a Hudsonian chickadee that at once struck me as unusually dark and sooty in appearance. This tendency to darkness of plumage is shown in several of the Labrador birds, and is due, I believe, to the damp climate. As Siebold says, in "The Birds of Siberia," "It seems too bad to shoot these charming little birds, but as the 'Old Bushman' says, 'What is hit is history, and what is missed is mystery," " and in order to be sure to make a real addition to knowledge it was necessary to procure specimens. It was apparently an undescribed subspecies and on my return I had the pleasure of describing it and adding it to the list of birds known to science. ${ }^{1}$

The moon was nearly full that night, and the next morning was clear and calm. A white mist filled the valleys among the hills and gave the appearance of glacial ice leading down to the water's edge. A fox sparrow sang from

1. In The $A u k$ of January, 1916, I gave a description of this race of chickadees, naming the bird Penthestes hudsonicus nigricans. Strangely enough, this Labrador chickadee was so kind as to return my visit, for a large migration of them occurred throughout the New England States and even to New Jersey and Staten Island in the winter of 1916-I7. (See The Auk for April, 1917.) 
the shore, a loon called as he flew overhead, and above the constant murmur of the brook could be heard the whistles, groans, and calls of a Labrador jay in the forest. We weighed anchor and drifted down slowly with the tide. The men had caught in nets a couple of dozen two- and three-pound trout, and we were therefore well supplied with food. As we were drifting, Louis.Robin and his son George came up to visit us from the telegraph-station at the mouth of the inlet, and the talk wandered from fish to Indians and from caribou to walrus. Only this spring a walrus - une vache marine - was shot on an island in Shecatica Bay. They heard what they thought to be a man crying for help, but found a young walrus eight feet long and shot it. One was caught at Harrington in seal-nets four years ago, and still another at Esquimaux Point ten years ago. In Cartier's time they were common on these shores, - he speaks of seeing them near the Bay of Seven Islands, - but they are now nearly restricted to much more Arctic regions.

The caribou still come down in the winter from the interior to the shore and occasionally 


\section{IN AUDUBON'S LABRADOR}

visit the islands. Forty were shot between St. Augustine and Old Fort in the winter of I9I415. These are the woodland caribou and also the smaller barren ground or Cabot's caribou, a form distinctive of Labrador and named by Dr. Glover M. Allen after Mr. W. B. Cabot, the well-known Labrador explorer. I was so fortunate as to obtain a pair of antlers of this caribou taken at Blanc Sablon. The eyes of the old man Robin sparkled as he spoke of the pleasures of dog-sledding and of the winter's hunt. !

Shecatica Inlet is a good example of the fiordal character of this coast. Daly ${ }^{1}$ quotes the description of the coast of Norway from Trondhjem to Bergen, as given by J. D. Forbes in "Norway and its Glaciers," as applicable to the southern part of the eastern coast of Labrador. It also applies to this southern coast. Forbes says that a series of inlets penetrates "in all directions a low, bare, rocky land, partly island, partly continent, nowhere rising but to a very small height above the sea, and so monotonous in charac-

1 The Geology of the Northeast Coast of Labrador, Bulletin Museum of Comparative Zoölogy, Harvard College, vol. XXXviII, p. 2 IO. 

ter, and destitute of long reaches or natural landmarks as to seem to require an almost superhuman instinct for its pilotage." G. W. Gregory, in "Nature and Origin of Fiords," draws the following conclusions: "Hence, the main fiords of Labrador, like those of Baffin Land, occupy valleys worn by preglacial denudation in an ancient and faulted plateau, which has undergone unequal uplift and subsidence in recent geological times." These various passages and inlets of Canadian Labrador resemble the fiards of Sweden, where the land is also but slightly elevated. Their irregularity suggests the cracks in a broken piece of glass. John Burroughs, writing of the Alaskan Coast, says: "The edge of this part of the continent for a thousand miles has been broken into fragments small and great, as by the stroke of some earth-cracking hammer, and into the openings and channels thus formed the sea flows freely."

Here and at several places along the coast dikes of dark trap-rock were to be seen cutting the gneiss. In New England where these dikes have not been under the sea they stand out above the gneiss or granite, for the trap-rock 


\section{IN AUDUBON'S LABRADOR}

is less easily worn down by the rain and the frost, but on the shores where the waves batter they are cut away and form chasms like the well-known Rafe's Chasm at Gloucester. In Labrador these dikes have recently risen from the sea and are, therefore, cut below the level of the surrounding granitic rock. I have seen similar but larger dikes on the eastern Labrador coast which suggest from a distance cuttings for roads across the country.

In sailing out of the inlet we startled a female red-breasted merganser, or sheldrake, with a brood of young. The ducklings at once hid themselves among the rocks on shore while the mother flew away. It was good policy for both parent and offspring, but very different from the actions of a brood of the same species that I had surprised in a different way the day before. I emerged from the woods on the shore of a lakelike expansion of the inlet and perceived a mother merganser with a dozen downy young a little over a gunshot away. The mother saw me at once and swam a short distance, nervously thrusting out her head; then dived and came up outside, enticing her brood to follow, which they did, swimming 206 


\section{SHECATICA AND JACQUES CARTIER}

in a compact bunch. By frequently repeating her tactics the young were drawn farther and farther away. They were having their first lesson of fear of man instilled into them; another time they would probably react without prompting. 


\section{CHAPTER $\mathrm{X}$}

A DESCENDANT OF THE CHEVALIER DE ST. PAUL, WITH REMARKS ON VINLAND THE GOOD AND THE PORT OF BREST

A FAVORING wind sprang up and we 11 said good-bye to the Robins and to Jacques Cartier's anchorage and passed inside of Shecatica Island. Here were two houses; in one lived a man wealthy in children - he had twelve - but poor in worldly goods until last winter when he caught a black fox. This he sold for twelve hundred dollars and at once purchased a cod-trap and a gasoline boat. I hope the increased income from the former will pay for the latter. I was once journeying in Cape Breton in a motor-boat, the engine of which was continually giving trouble. Its owner, an elderly Scotchman, was too strait-laced to give vent to his feelings in the ordinary manner, but finally, after long unsuccessful cranking, he turned to me and said, "A gasoline engine is a vexation of the spirit and a leaky pocket."

In the other house the family had been 208 


\section{VINLAND THE GOOD}

nearly exterminated by tuberculosis, the scourge of this coast. At first sight it seems strange that, in a country where the air is so pure, tuberculosis should be so common, but the cause is not far to seek. The houses are small, the rooms crowded, and the doors and windows are tightly closed for reasons that appeal very forcibly to the people. In summer the mosquitoes swarm, and nettings are practically unknown on the coast; in winter the cold is severe and warmth must be conserved. All ignorant people prefer to crowd together and dislike all ventilation. The ancestors of the most hygienic people in the world followed the same methods a short time ago. The habit of spitting is, however, the chief offense and a cause of the prevalence of this disease. Dr. George W. Corner has vividly described the situation. He says: "Spitting is the national sport of the fisherman, both indoors and out; and, when practiced by an infected man, in a tight, overheated, one-room shack, among a family of underfed children, the result may be imagined." He also says that "in the absence of statistics it has been estimated that one death in three in Newfound- 


\section{IN AUDUBON'S LABRADOR}

land and Labrador is caused by this disease." Dr. Grenfell and his entire staff are continually striving to remove the cause of tuberculosis, but educational work of this kind is necessarily slow. Dr. Arthur Wakefield, now at the front, for several years traveled about Newfoundland and preached in every village from the one text, "Open your windows and don't spit."

We sailed on through Chimney-Head Passage - "a passage only for those who know it" the captain said. Here was an ancient stone chimney formerly used in trying-out seal-oil. We passed Napetepi Bay and Anse à Malouin opposite, which was a "Bull" or "Boule," a round rocky island. Then Lobster Bay, nearly five miles deep leading up into the low mountains, opened up. There is a portage of only about a hundred yards at its head which leads to Napetepi Lake. To the south we could see for the first time the shadowy mountains of Newfoundland. Rocky Bay and Lydia Harbor were passed in turn. At the latter place was a single house and the captain told another sad tale of tuberculosis. Birds were almost absent. In the morning's sail we 


\section{VINLAND THE GOOD}

saw only eighteen black guillemots, one herring gull, and seven great black-backed gulls - not a single eider, murre, or razor-billed auk; the motor-boat had done its deadly work. We landed and explored Grassy Island with its sand-beach and fringe of strand wheat, an elevated elastic tundra of lichens, mosses, and curlew-berry, a pool of clear water, and beyond this, fifty or sixty feet above the sea, an elevated beach of large and small pebbles. The most skeptical would here be convinced of changing land-levels.

The mountain cranberry, the strand wheat, and the northern white birch have all been mentioned several times in these pages. They are of especial interest in the discussion that has gone on for so many years as to the location of "Vinland the Good," the land discovered by Leif, the son of Eric, sometimes called Leif the Lucky. Among the latest and most important contributions to this discussion are "The Finding of Wineland the Good," by A. M. Reeves; "The Voyages of the Northmen," by Julius E. Olson; "Notes on the Plants of Wineland the Good," by Professor M. L. Fernald; " "In

1 Rhodora, vol. I2 (I910), pp. 17-38. 


\section{IN AUDUBON'S LABRADOR}

Northern Mists," by Fridtjof Nansen; and "The Voyages of Norsemen to America," by Professor William Hovgaard. From all of these I have freely drawn for the following brief resume of the subject.

Although the discovery of America by the Norsemen took place about the year Iooo, detailed accounts of the Vinland voyages are not recorded until the thirteenth century in the "Saga of Eric the Red," and in the fourteenth, in the "Flatey Book." From the latter it appears that a young man named Bjarne Herjulfsson, intending to sail to Greenland from Iceland to visit his father, missed reckonings owing to northerly winds and fogs and finally reached a land which was "flat and wooded." The men knew it could not be Greenland, but Bjarne refused to go ashore and investigate; he turned away, and after many days reached Greenland. In the "Saga of Eric the Red" it was Leif who, sailing from Norway to Greenland, discovered this land. The "Flatey Book" says he followed Bjarne's directions and landed where "no grass grew and great glaciers were seen inland, while the coast between the glaciers and the sea looked 


\section{VINLAND THE GOOD}

like one large flat stone. . . Then said Leif: $\therefore$... Now I will give this land a name and call it Helluland.' " The glaciers suggest Baffin Land, although it is generally supposed to be Labrador. Then they sailed to another land which was "flat and covered with woods, and there were extensive white sands, wherever they went, and the beach was not steep. Then said Leif: "This land shall be named according to its nature and it shall be called Markland." ' Labrador at Sandwich Bay is one of the interpretations of "Markland"; the usual one is Newfoundland. Again they sailed out into the open sea with a northeast wind, and after two days saw land and it was here that vinvio and vinber were found, or grapevines and grapes as ordinarily interpreted. They were first seen by Tyrker Southman, Leif's foster-father, a German, who said to Leif, "I was born where there is no lack of either vinvio or vinber." Leif therefore named the land Vinland. Hveiti and masur or mosurr wood are also mentioned several times in the Saga. These terms have been interpreted to mean Indian corn or wild rice and maple, but Professor Fernald has shown that they 


\section{IN AUDUBON'S LABRADOR}

must refer to strand wheat and the northern white birch. Strand wheat occurs on both sides of the Atlantic; on the American side it extends south to the Maine coast and the Isles of Shoals, and it has recently been found on the tip of Cape Cod. It is used in Iceland today for making flour for bread and was a familiar plant to the Norsemen. The white birch of northern Europe and Labrador are believed by some to be the same species. On the eastern Labrador coast this tree is much stunted and distorted by the severity of the climate, the violence of the gales, and the weight of the winters' snows. The grain of the wood is in consequence often curiously twisted. Hard knobs, induced perhaps by partial breaks, are common, and from these much-prized drinking-vessels were made by the ancient Vikings.

The wild grape does not appear even at a distance from the coast north of the St. John Valley in New Brunswick, and is found on the coast only as far north as the mouth of the Kennebec, but is common to the south of Cape Ann. On Cape Cod the large fox grape, the ancestor of the well-known Concord grape, is particularly abundant. 


\section{VINLAND THE GOOD}

The description of the natives seen by the Norsemen and called Skraelings corresponds very closely with that of the Eskimos. They wore fur clothing and came in skin canoes and were said to live in caves and holes. In the "Saga of Eric the Red" the following passage occurs: "They saw a great number of skin canoes, and staves were brandished from the boats, with a noise like flails, and they were revolved in the same direction in which the sun moves." This, of course, suggests kayaks and the double-bladed paddle of the Eskimos.

Those who believe that Vinland was on the Nova Scotia or Newfoundland coast are forced to the conclusion that the Eskimos formerly extended their range farther south, or that the Norsemen did not discriminate between the Eskimos and the Indians and called them all Skraelings. I have found in the ancient shellheaps of the New England coast bone needles which resemble closely the same articles made and used to-day by the Labrador Eskimos. Such bone implements are, however, made by Indians. Pottery, plainly of Indian manufacture, is also common in the shell-heaps. 


\section{IN AUDUBON'S LABRADOR}

There is very little difficulty about the general location of Helluland and Markland, and there is no reasonable doubt that the Norsemen reached Labrador and very probably Newfoundland. Vinland the Good is, however, a different matter. The description of the landfall as given in the Sagas can be made, by the use of a little imagination, to fit a number of places exceedingly well. Its location may depend to a considerable extent, therefore, on the significance of vinber. If the Norsemen really found grapes and vines, - and it would seem that Leif's foster-father definitely referred to grapes, - Vinland must be at least as far south as southern Maine, possibly as Professor Hovgaard suggests, on the sandy shores of Cape Cod, notwithstanding the fact that the Saga allows only two days for the voyage from Markland. On the other hand, the terms vinber and vinland may have been used to make the voyages appear more marvelous or in order to induce settlers to come there. Such exaggeration or myth-making is common enough in ancient legends. Eric the Red frankly states that he gave Greenland its name, "because men would be more read- 


\section{VINLAND THE GOOD}

ily persuaded thither if the land had a good name."

Another explanation is that of Professor Fernald, who finds that the term vinber, or wineberry, was used for various berries from which wine was made, particularly the mountain cranberry. He has gathered a great deal of evidence in support of this theory, which appears to reconcile many difficulties. If a cargo of vinber was carried away in the spring it might well have been one of mountain cranberries, for at this season they are in good condition, which, of course, is not the case with grapes. The Saga is, however, obscure on this point and does not say definitely that the berries were gathered in the spring. The passage is as follows: "It is said that their after-boat was filled with vinber. A cargo was cut for the ship, and when the spring came, they made ready and sailed away."

If, as the Saga relates, there was no snow in Vinland during a winter spent there by the Norsemen, and the cattle were able to graze during the whole season, it is evident that this was not the country of the mountain cranberry. The description fits an especially mild 


\section{IN AUDUBON'S LABRADOR}

winter on Cape Cod. From this description of the climate and the statement of Tyrker the German it is plain that the Saga wishes to convey the impression that the real grape was found.

Nansen says: "Apart from the surprising circumstance of the Icelanders having called a country Wineland the Good because whortleberries [mountain cranberries] grew there, the explanation is inadmissible on the ground that whortle-berries were never called vinber [wine-berries] in old Norse or Icelandic. . . . In ancient times the Norse people did not know how to make wine from any berry but the black crowberry [curlew-berry]; but there are plenty of these in Greenland, and it was not necessary to travel to Labrador to collect them." Hovgaard says it is "at least improbable that the name vinber was applied generally in Scandinavia to berries other than the grape at the time of the Vinland voyages." He finds that Bishop Jon taught the people of Iceland to make wine from Krcekiber in the year 1203 , or after the time of the Vinland voyages. Krakiber is the crowberry or curlew-berry. 


\section{VINLAND THE GOOD}

Nansen calls attention to the frequent reference in the Saga to vinvio as well as vinber, to the vines as well as to the grapes. These grapevines were cut by the Norsemen and formed part of their cargoes. Hovgaard suggests that they were used and were of great value in tying the bottom planks of the ships to the frames. A Viking vessel, the so-called Gokstad ship, was found in I880 near Sandefiord, Norway. It was in an excellent state of preservation owing to the fact that it had been used as the burial casket of a chieftain, and was covered by a mound of blue clay. In this vessel the planks were fastened to the frame by withes.

I cannot help agreeing with Nansen that the Norsemen would not have named a marvelous new country after such a familiar berry as the mountain cranberry. It is as if a native of New England should name a new and wonderful country "Huckleberry Land" even if huckleberries grew there abundantly. Either, therefore, Eric sailed a long distance south of Newfoundland and found the real grape when he named Vinland, or, like a dutiful son, he raised the grapes from his own fertile imagi- 


\section{IN AUDUBON'S LABRADOR}

nation after the manner of his father in naming Greenland.

Nansen contends that "Wineland the Good was originally a mythical country, closely connected with the happy lands of Irish myth and legends - which had their first source in the Greek Elysium and Isles of the Blest, in Oriental sailors' myths, and an admixture of Biblical conceptions." He believes, however, that the Norsemen discovered a part of North America and that the tales of wine and wheat are later inventions.

By way of summary of the facts and fancies regarding the voyages of the Norsemen, the following seem to be reasonable:-

I. The Norsemen discovered America about the year 1000 and landed at Baffin Land, Labrador, and probably Newfoundland. The more northern of these regions they called Helluland, the more southern, Markland.

II. South of Markland was a country they called Vinland the Good. This was: -

(I) A mythical region with the familiar attributes of grapes and wheat, wine and bread like those of many 220 


\section{VINLAND THE GOOD}

another such mythical land pictured from the earliest times.

(2) It was a region where they found the true grape. In this case the land was at least as far south as southern Maine and may have been Cape Cod. The reasons in favor of this supposition are as follows: -

(a) The statement of Tyrker the German, who was familiar with the true grape.

(b) The fact that they cut the vines to bring back in their vessels. These were prob'ably used in shipbuilding.

(c) The statement that there was no snow in Vinland during the winter and that the cattle grazed during the entire season.

These three statements, together with the fact that the mountain cranberries were probably not used for making wine by the Norsemen at this early date, and the improbability of their naming a wonderful land after such a 


\section{IN AUDUBON'S LABRADOR}

familiar and commonplace berry, negative the idea that by vinber they meant mountain cranberry.

Old Fort Island - Vieux Fort au large with its summer houses and fish-stages could be seen in the distance from Grassy Island, but we sailed seven miles inland to the winter village of Old Fort. This is on the mainland at the head of a bay behind a sheltering island. Here were about fifteen dwelling-houses and a schoolhouse, but only one family was there looking after some captive foxes. The rest of the people were fishing at the islands. A deserted village it certainly was. Not even dogs were to be seen, although there were elevated platforms of logs for the safe storage of dog-food near the houses. On one of these were the ghastly remains of an Eskimo dog kept to feed his kindred. Tall wigwam-shaped wood-piles, frames for stretching sealskins, little gardens containing a few lettuces and turnips, rank with weeds and surrounded with high fences, komatiks shod with bone cut from the jaws of whales - all these were familiar objects in this cold land. Some bits of broken 


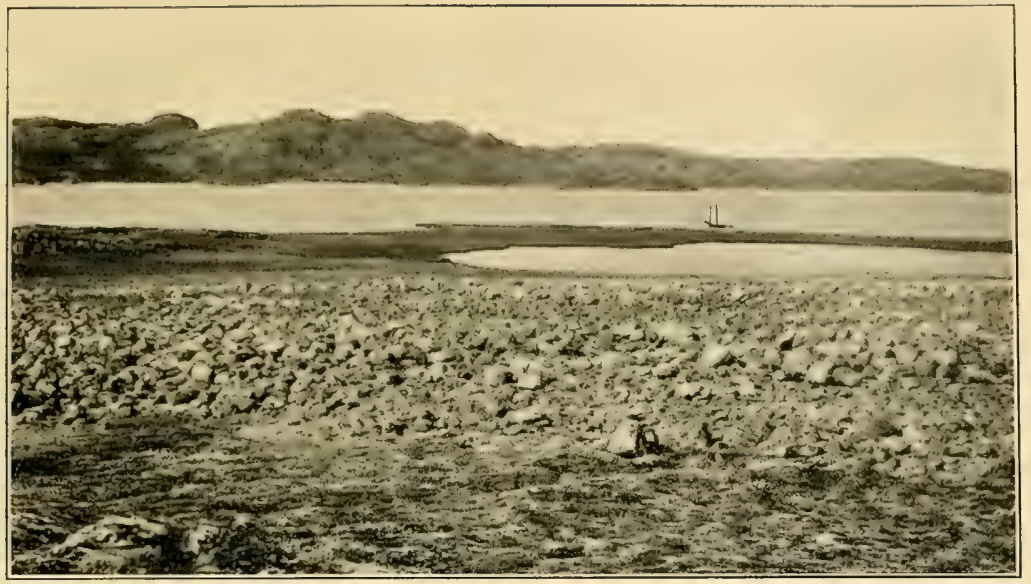

GRASSY ISLAND：RAISED BEACH

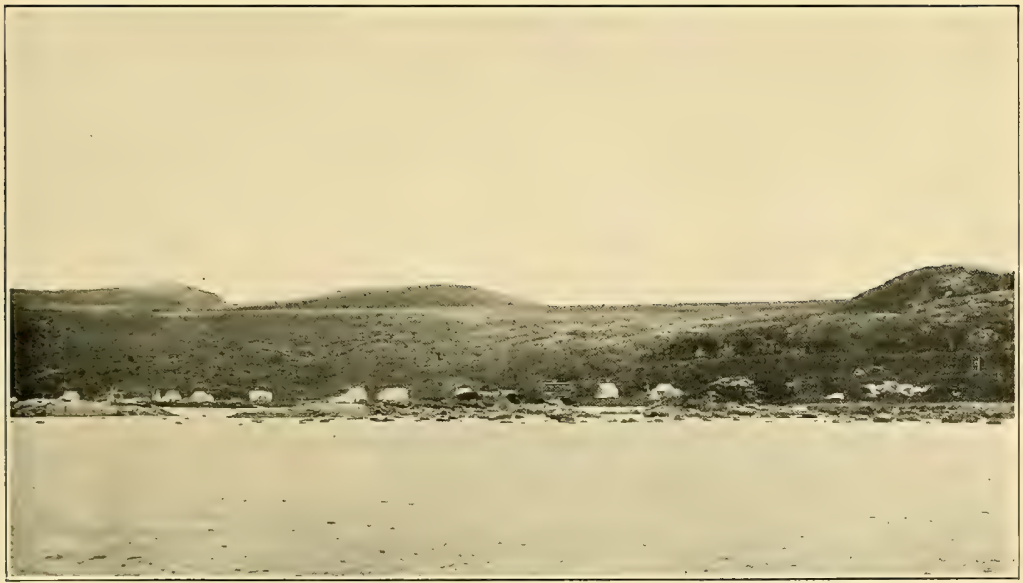

OLD FORT: SITE OF BREST

Showing Raised Beaches 



\section{THE PORT OF BREST}

china arranged in squares and circles showed the former presence of children. Above the narrow shelf close to the beach on which the houses were built was a terrace, and about a hundred and fifty feet higher another terrace, while on either side still higher were others; all bore the familiar earmarks of raised beaches. I regret that I had no means of measuring their exact heights.

Old Fort was the ancient Port of Brest. This is clearly proved and set forth in detail by W. C. Gosling in his valuable work on Labrador. The port was founded at the beginning of the sixteenth century by the hardy Breton and Basque fishermen, probably before Jacques Cartier's arrival in I534. Audubon's friend Samuel Robertson of Sparr Point, the grandfather of my friend of the same name and place, misled by a tradition that Brest was a city of some size and importance, added much confusion to the subject by locating the port at Bradore Bay. He described in the "Proceedings of the Literary and Historical Society of Quebec" for February, I843, what he believed to be the remains of a city of some two hundred houses or a thousand inhabitants that 


\section{IN AUDUBON'S LABRADOR}

he found at this place. These statements have until recently been generally accepted and copied by historians. Dr. Samuel E. Dawson, however, in a paper read before the Royal Society of Canada on May 24, 1905, showed that on all the early maps Brest was located at Old Fort Bay. He showed, however, that it was chiefly a summer fishing-port with possibly a blockhouse and a few men to guard the property in winter, and that it was not even mentioned by Champlain or Charlevoix or in any of the "Jesuit Relations." It is believed that the ruins found by Samuel Robertson were undoubtedly those of Fort Pontchartrain and the settlement made by Legardeur de Courtemarche early in the eighteenth century. This settlement was probably abandoned and fell into ruins about 1760 , and it was these ruins that Robertson, eighty years later, thought to be the remains of the town of Brest. It is interesting to note here that this Samuel Robertson of Sparr Point married a daughter of Mr. Jones, of Bradore Bay, and it is probable that in his visits to this place these erroneous ideas of Brest were conceived. 


\section{THE PORT OF BREST}

The botanist and I explored the hinterland on the following day; it was a land of rocky peaks and lakes and bogs with small patches of forest in the protected valleys. The peaks were hills in height, four or five hundred feet at the most, but mountains in contour and general appearance. As Shaler says, "if a mountain or hill goes about it aright, it can get an amazing dignity without assaulting the heavens in its efforts." Although the bogs were small, owing to the multitude of rocky peaks, yet deep, soft moss was everywhere, even on the mountains, except on the exposed rocks.

At Shecatica we had seen several spruce grouse with their young, and we found them common here. It is a bird that is easily approached, often within a few feet, before it takes alarm and flies away. The young, eight or more in a brood, were only about a quarter grown, but able to fly well. They generally flew off and disappeared while their mother remained on the ground, where she was diffcult to see unless among white reindeer moss. Sometimes she took to a spruce tree, where she cocked up her tail, nodded her head and croaked and clucked nervously. In the spring 


\section{IN AUDUBON'S LABRADOR}

these birds are fond of the new tips of the spruce and fir, but at this time of year they were eating curlew- and snow-berries, young leaves of the oval-leafed blueberry, ferns, and the seeds or achenes of sedges.

We lay secure in our quiet harbor of Old Fort that night, while, as we learned later, the Strathcona with Dr. Grenfell on board spent the night rolling in a heavy sea outside. With a good pilot he would have had a quiet night, and we should have spent a delightful evening with him. He went on the next day and we entirely missed him.

On July 26, I833, Audubon states in his Journal: "We left Baie de Portage before five in the morning, with a good breeze, intending to come to at Chevalier's settlement, fortyseven miles; but after sailing thirty, the wind failed us, it rained and blew, with a tremendous sea which almost shook the masts out of our good vessel, and about eight we were abreast of Bonne Espérance; but as our pilot knew as much of this harbor as he did of the others, which means nothing at all, our Captain thought prudent to stand off and proceed to Bras d'Or." On this same day of July eighty-two years 


\section{THE CHEVALIER DE ST. PAUL}

later our captain guided us safely in the Sea Star among the maze of islands from Old Fort into the mouth of the Esquimaux or St. Paul River to "Chevalier's Settlement," and we paid our respects to Louis Owen Chevalier, whose father, Louis David, was a baby at the time that Audubon passed along the coast. His first ancestor to come to the New World was Jean Godefroy, who sailed from Lintot, Normandy, in I626. He settled at Three Rivers when the town was founded in 1634 , and in I669 he was ennobled as the Chevalier de St. Paul. His third son, Jean Amador Godefroy de St. Paul, was a fur-trader along the Labrador coast. On the 20th of March, I706, he was granted by Philippe de Rigaud, Marquis of Vaudreuil and Governor of New France, a large tract of land, ten leagues frontage by ten leagues in depth, on "La Grande Rivière, pays des Esquimaux." 1 This seigniory has been passed from father to son, although we were told that the papers are now lost and that the present representative does not retain his privileges.

1 I am indebted for this information to Mr. L. P. Sylvain, Assistant Librarian of the Library of Parliament at Ottawa. 


\section{IN AUDUBON'S LABRADOR}

I found the descendant of the noble family, a man in the sixties with white hair and beard and a certain aristocratic manner of speech, dining with a descendant of another early adventurer in these regions, Mr. W. B. Cabot. Their ancestors were doubtless served with joints of venison and flagons of wine, but their descendants were dining on salt fish and tea. Mr. Cabot had found some of his Indian friends up the river, which sufficiently accounted for his presence. Chevalier told me that one of his great-uncles had been a taxidermist for Audubon and had traveled with him, and he was glad to hear about the famous ornithologist. The little settlement of fourteen or fifteen houses and a church is deserted in summer save for our friend, who ekes out a scanty existence by the netting of salmon.

The shores of the bay and the mouth of the river were everywhere rocky and pseudomountainous, - if I may use the word, - with little forests hanging in the gullies or creeping down the valleys like glaciers. The sandy shores about the village were thick with grass growing on the soil enriched by years of fishing and sealing industries. A young bull was 


\section{THE CHEVALIER DE ST. PAUL}

kept there one summer, and he throve and grew after he had killed several dogs and proved his mastery.

The river itself is one of the largest that pours its waters into the Gulf, but, owing to the fact that the first falls are a long distance from the mouth, it is not used for fly-fishing. All the salmon that are caught are taken in nets by the Chevalier. 


\section{CHAPTER XI}

BRADORE BAY AND PERROQUET ISLAND

7 Hext day we sailed on the final lap of

1 our course and passed out through a narrow passage between Esquimaux Island and the shore. The captain called it a rigolet, but the English-speaking inhabitants of this region probably called it a tickle. In places we could have touched the rocks with a salmon-rod, and yet the water was almost too deep for anchorage. I landed on the side of a cliff and filled the water-jugs from a brook that spouted down over the rocks.

A rounded peak of Esquimaux Island that had been burned over several years ago presented a striking and singular appearance. The irregular rock-surfaces standing out in their green surroundings were gray in color bordered with pink, while in the unburned areas this border was lacking. The pink was the color of the naked granitic rock deprived of its covering of lichens and vines. It will be many years before the lichens creep down over the burned places 
and the moss and curlew-berry and spruce creep up.

The name of this island is doubtless derived from the fact that Eskimos formerly inhabited it. Gosling says that there is an authenticated tradition "that about the year I640 the Montagnais, armed by the French, attacked the Eskimos, who were encamped at Eskimo Island in St. Paul's Bay, and slew about a thousand of them." There is much difference of opinion as to the former distribution of the Eskimos, who are now not found south of Hamilton Inlet on the eastern coast. In the latter part of the eighteenth century, in Cartwright's time, they were found as far south as the Straits of Belle Isle, and Gosling says that at the beginning of that century they were found along the coast of the Gulf of St. Lawrence as far west, at least, as Pointe des Monts, where one of their battles with the Indians took place. The name Esquimaux Point suggests, of course, the former existence of the Eskimos at that place. Battle Harbor is generally thought to be so named because here, a few years before the English conquest of Canada, the last important battle between the Indians and the Eskimos is believed 


\section{IN AUDUBON'S LABRADOR}

to have taken place. Gosling shows that this cannot be the origin of the name, for on maps published two hundred years prior to this supposed event the name "Batal" appears, the Portuguese for boat or canoe. Corte Real, the Portuguese, probably saw this land in the year 1500 .

It is a significant fact, and one that throws doubt on the former western extension of the Eskimos in the Gulf of St. Lawrence, that Jacques Cartier does not mention seeing Eskimos in this region, but does mention the Indians. Gosling believes this is to be explained by the supposition that the Eskimos, induced by the desire to obtain European goods, first went to that locality in the latter part of the sixteenth century.

We sailed by Salmon Bay and Jack Nasty Passage, where some years ago a whale stranded itself among the reefs. Here it was finally killed by many charges of buckshot.

Bonne Espérance, - "Bonny," - the great fishing-establishment of the Whiteleys, was left on our starboard side. A group of trig, whitepainted buildings, a red chapel, extensive fishflakes and stages, and a fleet of fishing-barges showed the character of the place. 


\section{BRADORE BAY AND PERROQUET ISLAND}

As we squared away from Bonne Espérance, three porpoises appeared on our windward side and accompanied us for over an hour. At times they came close to us, pushing their backs and long, backward-curving fins out of the green water amid a shower of spray, and displaying their white flanks, which contrasted well with their lead-colored backs. As we watched them, we were startled to see one suddenly turn at right angles to his course and advance under water - his trail plainly visible as a light-green line - directly towards our little schooner. I could not help thinking of a torpedo discharged from a submarine, and held my breath, momentarily expecting the shock of contact. The porpoise, however, passed harmlessly beneath the schooner and shortly after was seen returning. This performance occurred again and again, and was no doubt a form of play or game on the part of those great beasts. It was so interesting that even the botanist was aroused from his state of introspection, occasioned by the rough water, and "sat up and took notice."

The birds seen in this traverse were few: a dozen or more razor-billed auks flew about the 233 


\section{IN AUDUBON'S LABRADOR}

waves or dived beneath them, two or three Wilson's petrels pattered over the surface, a few kittiwakes soared overhead, three gannets passed us, and puffins, at first few in numbers, became abundant as we neared our destination.

There was a heavy sea with wisps of fog and little wind, and we rolled unpleasantly and made little progress off Perroquet Island. At last, however, we managed to crawl in among the low, flat rocky islands which guard the little harbor of Bradore. Inside were a dozen Newfoundland fishing-schooners at anchor, a small number compared with the fleet Aubudon found here. He says: "Bras d'Or is the grand rendezvous of almost all the fishermen that resort to this coast for codfish. We found here a flotilla of about one hundred and fifty sail, principally fore-and-aft schooners, a few pickaxes, etc., mostly from Halifax and the eastern portions of the United States. There was a life and stir about this harbor which surprised us after so many weeks of wilderness and loneliness - the boats moving to and fro, going after fish, and returning loaded to the gunwales, others with seines, others with capelings for bait. A hundred or more were anchored out 234 
about a mile from us, hauling the poor codfish by thousands; hundreds of men engaged cleaning and salting, their low jokes and songs resembling those of the Billingsgate gentry."

A few houses were scattered about the islands; there were wharves and storehouses; boats filled with men in oilskins were passing back and forth from the schooners to the shore; children in scanty clothing were playing fishermen with great sweeps; and the whole place smelled of fish. One could look down through the clear water and see hundreds of dead fish lining the bottom. It did not look inviting for a bath. The Abbe Huard says of this harbor that it is made "by a group of little islands of a very picturesque character separated by narrow channels - the whole place designed for a future American Venice." The abbé has a keen sense of humor, which is continually cropping out in his book on "Labrador et Anticosti," but the most amusing bit, of which, however, he was apparently unconscious, is a footnote on page 435 in which he says: "It appears that the Esquimaux were evangelized in $\mathrm{I} 763$ by Cartwrigh [sic], Moravian minister"! I am sure Captain Cartwright would laugh in his grave 


\section{IN AUDUBON'S LABRADOR}

if he should hear this. He gave the Eskimos a square deal, however, which is more than some missionaries have done.

At Bradore Bay in Audubon's time dwelt a Mr. Jones, whose fame still lingers in this region, and tales are still told of his grand style of living. One of his sisters, as I have already stated, married the first Samuel Robertson of Sparr Point, and was living there when Audubon called. A son of Mr. Jones is still living an old man over eighty years of age - at Wolf Bay, Cape Whittle. We saw his substantial houses from a distance, but it was one of our very busy days and we were unable to pay him a call. Audubon has given an anusing account of this settler at Bradore in his "Episode" on "The Squatters of Labrador," but he refers to him as Mr. - He was embarrassed by having Mrs. Jones point to some "vile prints hung on the bare walls, which she said were elegant Italian pictures," and he had to compose his features when she described a musical instrument, at that time sent away for repairs, which had at one end "a crooked handle, by turning which round, either fast or slow, I do assure you we make most excellent music." The fam- 
ily lived very comfortably and were most hospitable to Audubon and his party. "During our stay at Bras d'Or," he says, "the kindhearted and good Mrs. - daily sent us fresh milk and butter, for which we were denied the pleasure of making any return." Mr. Jones was an interesting man who had seen much of the world, but was well content and happy to settle here where he earned a comfortable living by sealing, fishing, and trapping. "Whenever the weather was fair, he walked with his dame over the moss-covered rocks of the neighborhood; and during winter killed Ptarmigans and Caribous, while his eldest son attended to the traps, and skinned the animals caught in them. He had the only horse that was to be found in that part of the country, as well as several cows; but, above all, he was kind to every one, and every one spoke well of him." The house with all its interesting contents was long ago burned to the ground. It stood near where the house of Captain Blais now stands, on the eastern shore of the bay. The place is still called Jones's Point.

We caught but fleeting glimpses of the picturesque mountains which reach their climax in three rounded peaks at the head of the bay. 


\section{IN AUDUBON'S LABRADOR}

The highest of these, 1264 feet in elevation, was named Mount Cartier by Professor A. S. Packard in his visit to the coast in 1864. The fog was continually blowing in and blotting out the view. It might well have been here in Bradore Bay that Sir Humphrey Gilbert in his voyage of discovery in 1583 found himself befogged and "surrounded by hideous rocks and mountains bearing no trees and voide of any greene vegetation."

Fog is the common condition here, and as the mail steamer Meigle, on which I was to return by way of Newfoundland, touches at Bradore only in clear weather, it was very necessary, if I wished to take no chances, to go on to Blanc Sablon. In the absence of wind I descended to the level of a motor-boat, in which with all my luggage I set out for that harbor:-

"When suddenly a grosse fog over sped

With his dull vapour all that desert has And heaven's cheerful face enveloped;

That all things one, and one as nothing was, And his great universe seemed one confused mass."

The effect of the "grosse fog" on the skipper of the motor-boat was not such as is pictured in the next stanza of Spenser's poem, where he says, - 


\section{BRADORE BAY AND PERROQUET ISLAND}

"Thereat they greatly were dismay'd, ne wist

How to direct theyr way in darkness wide;

But feared to wander in that wastefull mist:

For troubling into mischief unespyde:

Worse is the danger hiden then descride"; -

for he appeared to know his way and to steer the boat at full speed with an assurance almost incredible until I realized that he was making use of his knowledge of the waves and currents and of the sound of surf on ledges, all of which were familiar guides to him in his life-work. In fact, he scorned my compass as entirely unnecessary, - he did not carry one himself, - and suddenly the lee side of Perroquet Island, at the exact place where we wished to land, loomed up out of the fog. Here puffins, or perroquets as they are called, have bred from time immemorial and here they still retain a hold notwithstanding the persecution they have endured. This, I am inclined to think, is greater at the present day than ever before, and will soon destroy them root and branch if nothing is done to prevent. The birds were noticeably less in number than they were when I passed the island in 1906. Audubon says: "As we approached the breeding-place, the air was filled with these birds, and the water around 


\section{IN AUDUBON'S LABRADOR}

absolutely covered with them, while on the rocks were thousands, like sentinels on the watch." Father Hesry said that puffins were formerly so numerous that when they rose in the air they hid the island from sight. This is doubtless a picturesque exaggeration on the part of the good father, but it gives a vivid idea of the great numbers of birds. At the time of our visit, in the year 1915, there were small places where the air and the water were filled with the birds; small groups could be seen on the rocks, but there were probably not one hundredth part of the hosts that Audubon found. Razor-billed auks were common, and I am inclined to think that they were holding their own much better than the puffins, as they lay their eggs in more inaccessible places under the rocks. As the puffins diminish, the auks seem to increase by comparison.

The island itself lies about halfway between Bradore Harbor and Long Point, at the entrance of the Bay of Blanc Sablon. The island is not far from the shore at Anse au Dunes. It is about a quarter of a mile across, nearly circular, with a flat, elevated center of red sandstone disposed in horizontal layers. On the western 


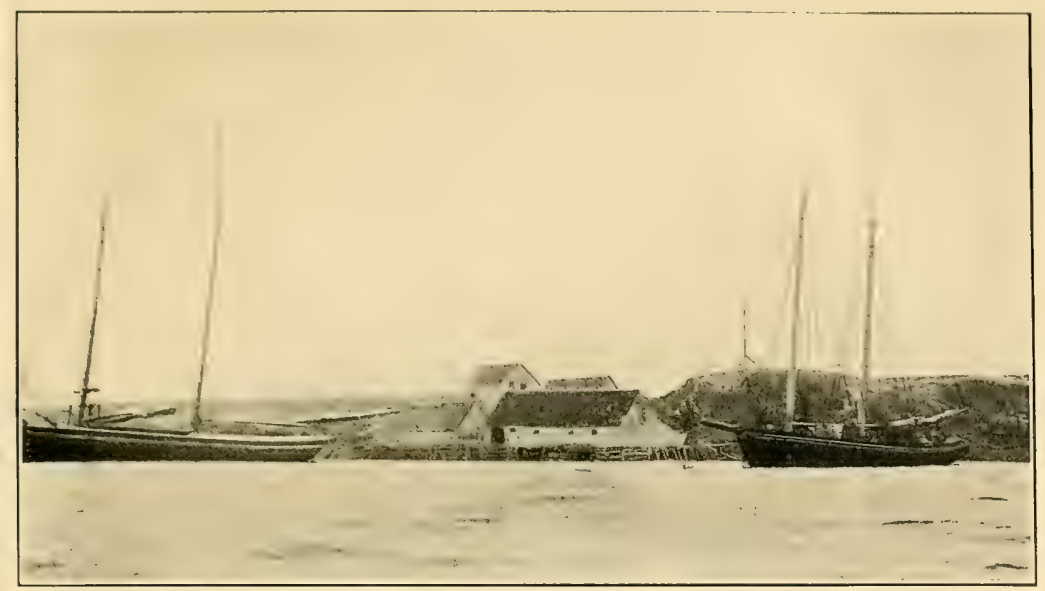

A GLIMPSE OF BRADORE IN THE FOG

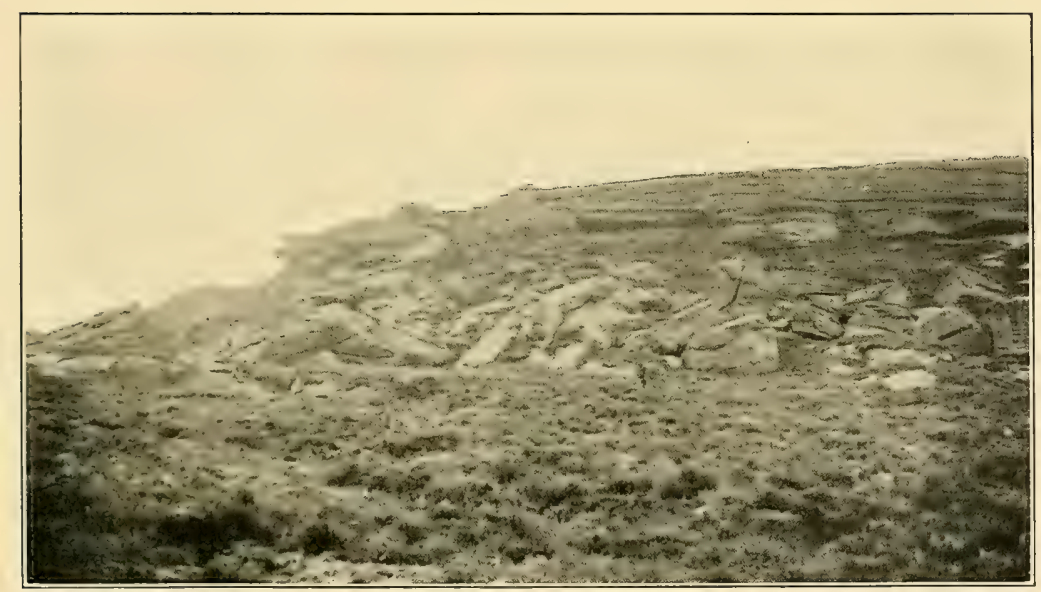

PERROQUET ISLAND 

and southern sides of this tableland are cliffs twenty or thirty feet high with great slabs of rock broken from the cliffs lying below. Everywhere in the soft reddish-black soil formed by the disintegration of the sandstone are the nesting-burrows of the puffins. These are to be found not only on the high land of the interior, but on the low shore-shelf, and one must watch his steps with care in this difficult ground. Some of the puffins nest under or among the blocks of stone, and here they are as secure as the razorbilled auks that lay their eggs in the same regions. I dug out one of the burrows in the soft soil and found it four feet long. It was about a foot below the surface during the first half of the course and descended to a depth of nineteen inches at the end. Here was a loose nest made of feathers and eel-grass in which was an oid bird and a young. The young was a charming baby - a fluffy ball of black down with a white breast, and a small black bill. The old bird with its great parrot-like beak, scarlet, blue, and white in color, and its solemn spectacled face, went flopping over the ground when I released it, and shortly afterwards took wing. Many of the holes had been dug out, and I learned that 


\section{IN AUDUBON'S LABRADOR}

fishermen from the Newfoundland fleet had frequently visited the island this summer, as there had been no one to prevent. These men also spread fish-nets over the ground, and the poor puffins, coming out of their holes, are entangled and fall an easy prey. The birds are also shot to some extent in the summer, but the spring shooting is the most destructive. Men camp on the island for four or five days at a time and shoot the birds as they fly about within easy gunshot. My informant boasted that he had brought down twenty-five birds at one shot, and added that the wounded birds crawl into the holes and escape. Boys lie behind rocks and knock the birds down with sticks. The puffins are destroyed ostensibly for food, but the element of cruel sport undoubtedly enters into the game and many birds are wasted or fed to the dogs. How long can this sort of thing go on before the puffin is as extinct as the great auk? A stop must be put to these practices before it is too late. The whole subject is considered in a later chapter.

Jacques Cartier visited this island, which he calls the "Island of Birds," and gives an unmistakable account of the puffins. He de242 


\section{BRADORE BAY AND PERROQUET ISLAND}

scribes them as "crows with red beaks and red feet: they make their nests in holes under the ground even as conies." He also mentions the large numbers of "Godets" - razor-billed auks - at the same island. 


\section{CHAPTER XII}

\section{BLANC SABLON}

W ${ }^{\mathrm{E}}$ pushed on in the fog, passed Long Point, the western entrance of the Straits of Belle Isle, and landed at Blanc Sablon. This was on Wednesday, July 28; the steamer was due on Friday, but fog delayed her until the afternoon of Monday, August 2. During the interval I was the guest of Mr. Edwin G. Grant, the agent of the great fishing-establishment of Job Brothers and Company, Limited, at Blanc Sablon. The most distinctive quality of the Labradorians, says the Abbe Huard, is their hospitality, and with this I can entirely agree. I began this expedition by a delightful experience of hospitality at Piashte Bay and I ended it equally pleasantly at Blanc Sablon. Mr. Grant and his charming family made my stay one always to be remembered. He has had charge here for Job Brothers and Company, a Newfoundland firm, for thirty-one years. There are seventy men under him: those who are nominally independent and own the 


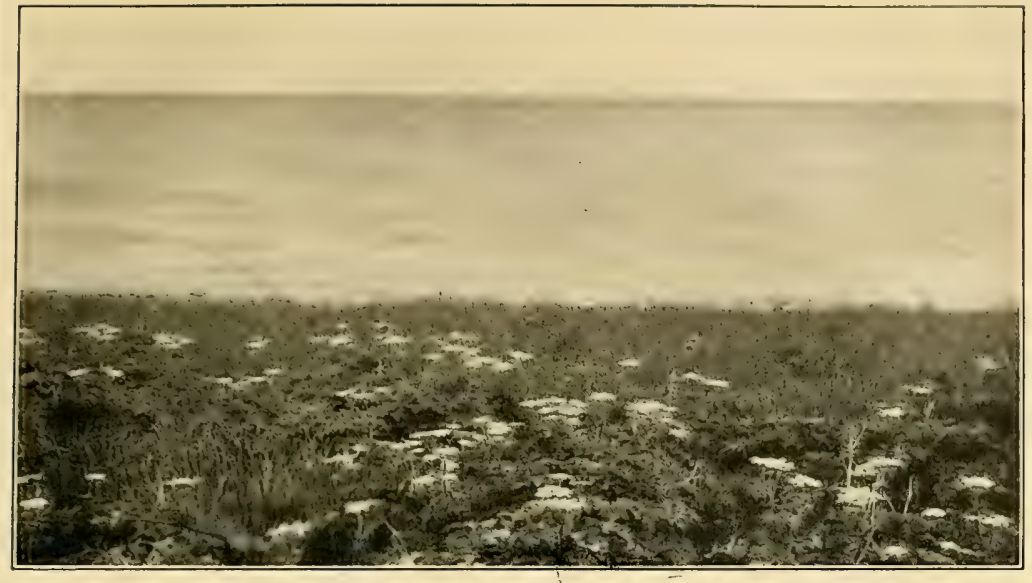

COW PARSNIPS AND STRAND WHEAT AT PERROQUET ISLAND

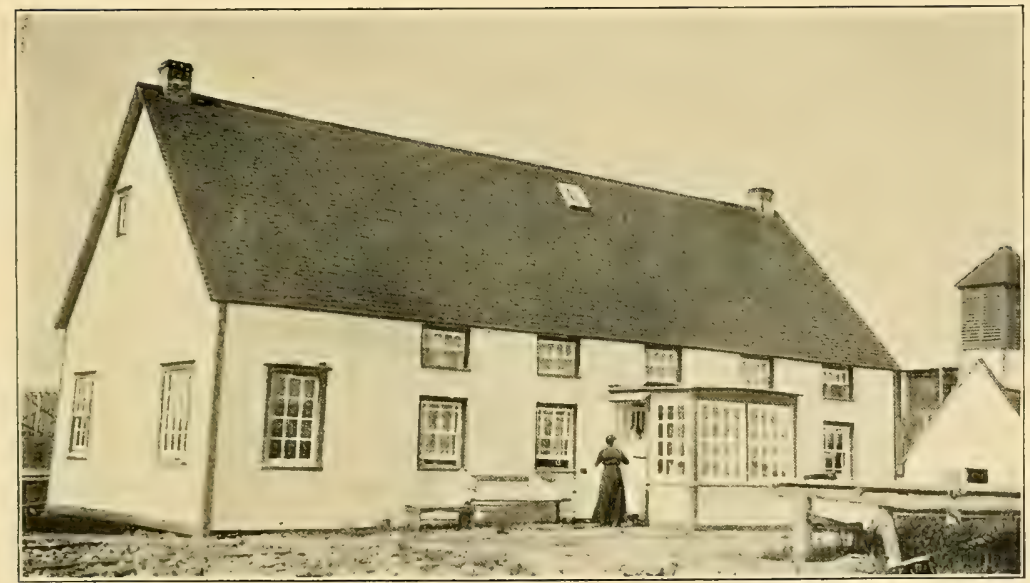

BLANC SABLON: JOB BROTHERS AND COMPANY, LIMITED 



\section{BLANC SABLON}

fish they catch, but sell them to the company, and the "servants" who work for wages. The company has also a branch, or "room" as it is called, at Île au Bois, another at Greenly Island, both near at hand, and still another at Forteau, some twelve miles down the coast. This "room" at Blanc Sablon was founded one hundred and fifty years ago by a firm from the Island of Jersey, and the main building, altered and rebuilt, still stands. With many of the terms used I was familiar from my acquaintance with Cartwright's Journals. A season's work, for example, is called a "voyage," and the term "cook-room" does not mean merely a kitchen, but refers to the whole building where the men eat and sleep.

Another word frequently used by Cartwright I found to be common here, and that is "alexander" applied to a plant used as a pot-herb. Mrs. Grant at once pointed it out to me, and said that she always gathered it when it was young and tender and cooked it as greens. I was somewhat chagrined to find that the identification I had made of "alexander" in editing Cartwright's Journals was an erroneous one, but I am glad to have this opportunity to 


\section{IN AUDUBON'S LABRADOR}

correct it. It is not, as I supposed, the cow-parsnip, - a very common plant here, - but a smaller plant of the same family known as "Scotch lovage."

It was a very picturesque and interesting place, and, considering the nature of the business done here, everything was as neat and clean as possible. Men in oilskins with large forks were pitching the fish - which, of course, means cod - from the trap boats on to the wharf. Here the fish were again transfixed and passed to the men in the fish-houses, who were deftly splitting, cleaning, and salting them. The wet fish, glistening with salt, are stacked in the low, darkened buildings, to await a favorable opportunity later in the season to be spread and dried on the extensive fish-flakes, which take up all available room among the buildings. This process, like haymaking, is an anxious one, and its speed and success are dependent on the weather.

The fresh livers are carefully washed and steamed, and the resulting oil is passed through three successive conical cloth strainers and comes out at the end looking good enough to drink - but this is a matter of taste. The 


\section{BLANC SABLON}

whole place was as neat as a laboratory. The unselected livers are thrown into great hogsheads outside, where they are allowed to rot, and the oil which gathers on the surface is used for various purposes other than medicinal. This process is not so attractive.

There is a fishing-room owned by a Jersey firm a short distance to the westward, on the other side of the little river which divides Newfoundland Labrador from Canadian Labrador. This is presided over by a Jerseyman, Mr. Morrell. He has charge also of the telegraph-office, but what he enjoys most, I suspect, is his garden, which he tends with a true garden-lover's care. I never saw such beautiful potato plants, green and luxuriant, and his turnips and lettuces were equally flourishing. The garden is protected by a high fence from destruction by dogs and is enriched with decaying seaweed. $\mathrm{Mr}$. Morrell never tired of telling about its charms.

I was impatient to explore this country which I had looked at with longing eyes nine years before from the deck of the steamship Home, so I soon left the business of fish and fishing and directed my steps inland with a whole afternoon before me. 


\section{IN AUDUBON'S LABRADOR}

The topography as well as the general appearance of Blanc Sablon at once strikes the traveler coming down the coast as something totally different from that of the country he has been passing through to the west. Beginning near the eastern limit of the Mingan Islands, which with the adjacent shore are composed of yellow Cambro-Silurian limestone laid in horizontal strata, the stretch of three hundred miles of coast by which we had journeyed as far as Bradore Bay is of a uniform granitic or gneissic character - primordial Laurentian rock, gray, white, or red, molten and crystallized. It is thrown about and piled up in hills and mountains that are worn down by the ages, and recently smoothed and grooved, scratched and polished by the last ice age. At Perroquet Island, near Blanc Sablon, one comes face to face with a sudden change in the character of the country, for here are dark-brown or red calcareous sandstones laid in horizontal strata and forming flat-topped cliffs. Similar cliffs extend to Chateau Bay and L'Anse au Diable, near the entrance of the Straits of Belle Isle. The fossils found in this stone show it to be of the Cambrian age, but although it is many millions of 


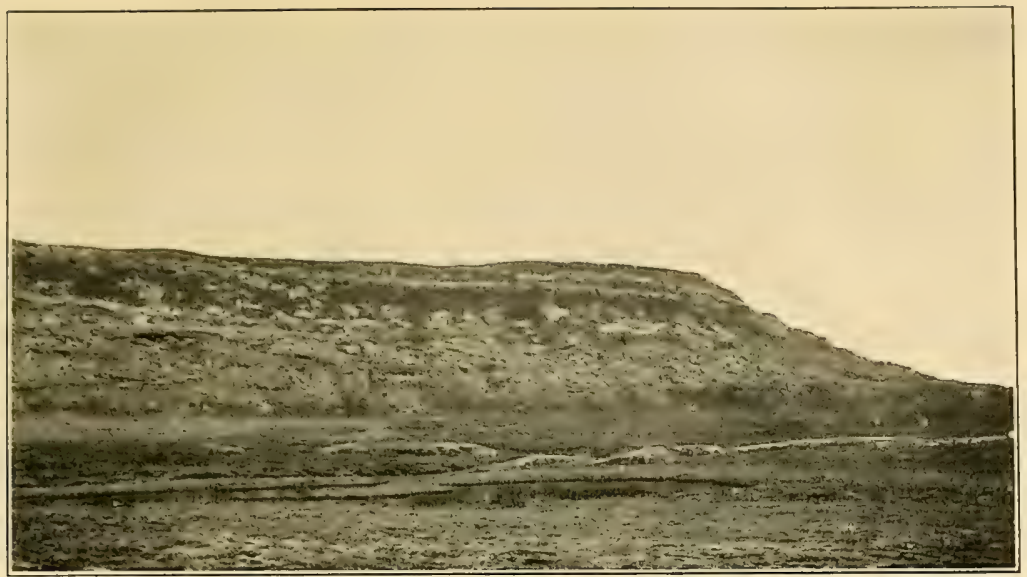

THE CLIFFS AT BLANC SABLON

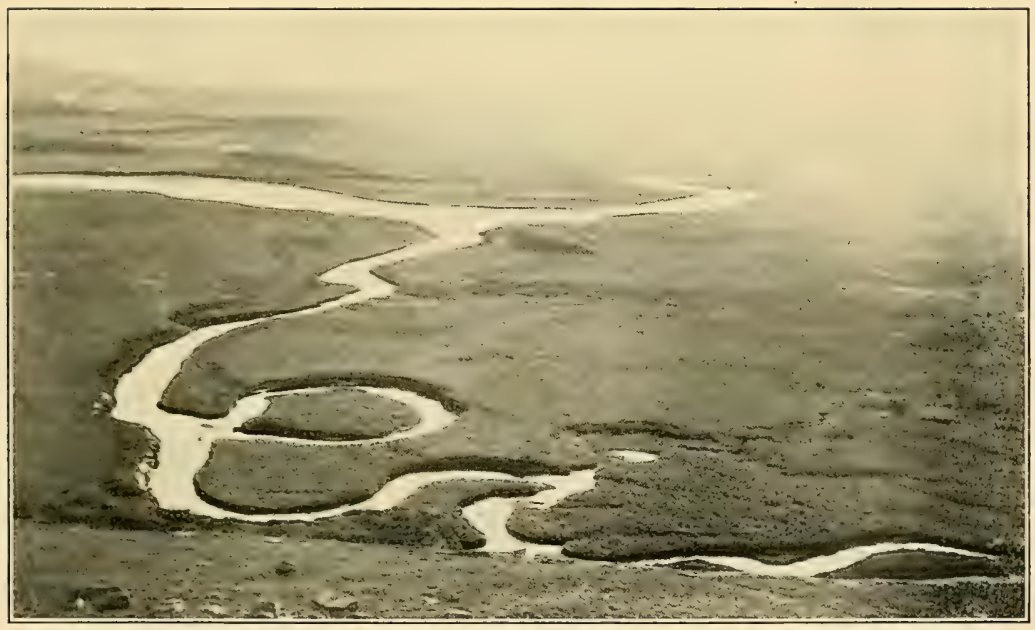

THE VALLEY AT BLANC SABLON

Photograph by Edmund Hunt 



\section{BLANC SABLON}

years old, it is very young compared with the crystalline rocks on which it rests. These latter rocks are exposed at the shore at Blanc Sablon, and are the source of the white sand which forms the beaches and small dunes at this spot. Hence its name, given by Jacques Cartier in I534.

The valley of Blanc Sablon is about a mile wide at the shore. Near the middle, flowing from a lake three or four miles to the north, runs a small river of clear, cold water, while from the cliffs on the east cascade one or two smaller brooks of clearer, colder water. The sandstone cliffs on either side of the valley, extending up to a height of about three hundred and fifty feet, are terraced and precipitous as on the faces farther east which are exposed to the sea. One might suppose that the valley was cut by the stream without any change of level of the land, but the series of raised beaches on the sea-terraces show as plainly as the same formations on the coast we have just traversed that elevation of the land here has also been going on. It is probable that the river has been cutting down and enlarging the valley at the same time that the land has been ele- 


\section{IN AUDUBON'S LABRADOR}

vated, but it also seems probable that the sea once entered more deeply than it does now, for the raised beaches extend back some distance up the valley. Some of the beaches are composed of great flat blocks of sandstone which are but little rounded; on other beaches at higher or lower levels the cobbles are more nearly spherical. This would point to a difference in the rate of elevation, as some of the beaches must have been hurried out of reach of the sea before the waves could finish their work of making the perfect cobble-stone. On the western side of the entrance to the valley the raised beaches, six or seven in number, are more distinct, and the cobbles are smaller and more perfect, showing, as might be expected, stronger wave-action than on the more protected eastern side. On these beaches I found a few granitic cobbles among those of sandstone.

The bed of the valley, in which the streams have meandered back and forth, is a flat, sandy plain well covered with vegetation. In one place is a small oblong mesa, perhaps forty feet high with steep sides, which has escaped the erosion of the river.

Much as I wished for a geologist to show 250 


\section{BLANC SABLON}

me all the interesting points in the topography of this valley, still more I missed the botanist, whom I had left at Bradore to return the way he came, for here, with two extremely different rock formations, - pre-Cambrian and Cambrian, - there was a variety and a wealth of vegetation I had seen nowhere else on the Labrador coast.

Professor M. L. Fernald, who in I9I0 made at this point a brief incursion into Labrador, has most interestingly described the region in the pages of "Rhodora." 1 "Here," he says, "was an ideal place to study the vegetation of a highly calcareous region side by side with the plants of a silicious and gneissoid area, and if any one doubts the dissimilarities of these floras he can find no better spot in which to undeceive himself than at Blanc Sablon."

Like him I was struck by the flat, grassy plains on the tops of the terraces, so different from the rounded and irregular surfaces of the granitic rocks with their wealth of mosses and lichens and their comparative paucity of grasses. Professor Fernald says: "The com-

1 M. L. Fernald, "A Botanical Expedition to Newfoundland and Southern Labrador," Rhodora, vol. I3 (I9II), pp. I09-62. 


\section{IN AUDUBON'S LABRADOR}

monest flower of these Laurentian plains is $\mathrm{Ca}$ rex rariflora, though with singular regard for its specific name it is by all means the rarest of its genus in New England." But the most surprising feature which is described and figured by Professor Fernald is the presence of stumps of forest-trees, and with them of a forest vegetation still lingering in the plains now fully exposed to the sun. Dwarf cornel, snowberry, linnæa, star-flower, clintonia, one-flowered pyrola, dwarf Solomon's-seal were most in evidence, and Professor Fernald mentions also such typical forest species as red baneberry, Dewey's sedge, great-spurred violet, and sweetscented bedstraw.

I measured several of the stumps that were a foot or two high with great sprawling roots, now destitute of bark and blanched by the sun and storm, but yet fully a foot in diameter or three feet in circumference. Sometimes a prostrate trunk three or four feet long would be seen. One pictures an ancient forest very different from the grassy plains with occasional clumps of dwarfed and stunted spruce and fir bushes that are here now.

Professor Fernald was much interested in 25\% 


\section{BLANC SABLON}

these stumps. He says: "In such accounts as I have found (except possibly Cartier's) the coasts of the Straits of Belle Isle are described as desolate and bare, and even Cartier, in 1534, entering the Straits and anchoring at Blanc Sablon, was so impressed with the barrenness that he wrote: 'If the land was as good as the harbors there are it would be an advantage; but it should not be named the New Land, but [a land of] stones and rocks frightful and illshaped, for in all the said north coast I did not see a cart-load of earth, though I landed in many places. Except at Blanc Sablon there is nothing but moss and small stunted woods; in short, I deem, rather than otherwise, that it is the land that God gave to Cain '; ${ }^{1}$ and again on his second voyage, in I 535 , he wrote: 'The whole of the said coast from the Castles as far as here [note by Professor Fernald - "From Chateau Bay as far as Brest, west of Blanc Sablon"] bears east-northeast and west-southwest, ranged with numerous islands and lands all hacked and stony, without any soil or woods, save in some valleys.' ${ }^{2}$ And at the present

1 J. P. Baxter, Memoir of Jacques Cartier (1906), p. 86.

2 Ibid., p. I30. 


\section{IN AUDUBON'S LABRADOR}

time the people at Blanc Sablon insist that there never has been any forest there and that no timber exists within four or five miles of the Straits. Yet, the first day I saw upon the terraces east of Blanc Sablon such plants as have just been enumerated, I was convinced that a forest must have been there, since these are so distinctly woodland species and so decidedly not plants typical of the Arctic barrens and tundra. So my delight can be imagined when, crossing with Kidder the tableland east of Blanc Sablon, we came upon buried logs and soon after found numerous stumps protruding from the moss. Some of the stumps, now much crumbled, were still a foot or more in diameter and indicated an ancient forest of considerable size. Just when the forest lived it is difficult to say, but if it still throve in the sixteenth century Cartier did not give a very clear indication of it. Only by such indefinite expressions as, 'except at Blanc Sablon there is nothing but moss and small stunted woods,' and 'without any soil or woods, save in some valleys,' did he indicate a possible forest cover. But here at least was a remnant of the forest which had once sheltered Carex Deweyana, Actea rubra, 


\section{BLANC SABLON}

and Viola Sclkirkii, though at the present time only shrubs or dwarf, straggling trees, as described by Cartier, thrive on the bleak and wind-swept shores of the Straits of Belle Isle; and that the forest was an extensive one and presumably once fringed the entire length of the Straits we are safe in assuming from the presence at Bonne Espérance, L'Anse au Clair, Forteau, Red Bay, and Chateau (as shown by the collections of John A. Allen and others) of a relict forest vegetation (sometimes further augmented by Onoclea sensibilis, Osmorhiza obtusa, Pyrola secunda, etc.) such as abounds on the terraces of Blanc Sablon."

The name of the island near at hand, "Île au Bois," hints at the former presence of a forest, yet if forests existed in Cartier's time we should expect a different account from him. Our knowledge of the history of the Labrador Peninsula since the glaciers melted a few thousand years ago would negative the possibility of a climate or topography that could support a forest such as these stumps and woodland plants suggest. Moreover, the stumps themselves can hardly date back to Cartier, who found "the land that God gave to Cain." 


\section{IN AUDUBON'S LABRADOR}

How can we explain the seeming paradox? Like many things in nature, the explanation, which I chanced upon in a walk over the plains to Anse Éclair, is very simple. The answer is, There has been no change; here are forest conditions at the present day, and here are plenty of forest-trees right before our eyes. Where the ancient white stumps are so prominent, the forest has been cut away, as is apt to be the case near settlements, but farther away to the east and west along the coast there are regions where forest conditions of darkness and quiet reign as truly as in the forest aisles where the trees rear their heads to the skies and wave and sough in the wind. The forest vegetation is the same in both cases.

One is at first disposed to deny these statements and say there are no trees here, merely spruce and fir bushes, insignificant things with flat tops clipped as it were by the Arctic blasts, but a close examination reveals true forest conditions. This examination is extremely difficult unless one is provided with an axe, or, better still, finds a place where wood-cutting has recently taken place, and the actual habits of the wood-cutter can be learned. This gives the key 


\section{BLANC SABLON}

to the situation and at once explains the existence of the ancient stumps. From a study of a number of partial clearings in various places about Blanc Sablon I found that the woodcutter often chooses a spruce or fir bush with a large central trunk, first cuts off the branches, and then the whole top of the trunk, leaving a stump exactly like the stump figured by Professor Fernald, which so irresistibly compels in us the conception of a lofty tree, a conception which, to a botanist, is rendered still more compelling by the presence in the neighborhood of the stumps of a type of vegetation found only in forests.

I regret that a photograph which I took of one of these trees that had been partly cleared of branches proved to be one of the mysterious failures which happen at times to all except superhuman photographers, but I am able to give the dimensions of this tree, which it seems to me thoroughly sustain my contention. The tree was a black spruce with a trunk forty-seven inches in circumference one foot from the ground. Its diameter was, therefore, about one foot, two and a half inches. This size of the trunk was maintained nearly to the highest 


\section{IN AUDUBON'S LABRADOR}

branch, which went off at right angles thirtytwo inches from the ground. From the center to the tip of the branches on all sides was nine feet, making a diameter for the whole tree of eighteen feet. It is true that many of the clumps of evergreen bushes are made up of a number of small trunks, but it is also true, as I found, that trunks of the size just described were not uncommon. In places the trunks are four or even five feet high. When the trees are continuous over a considerable area they form an almost impassable barrier. Many times, beguiled by a favorable opening, I determined to disregard the difficulties and pass through a hundred yards or so to open land beyond, when I found my progress so barred after a hard struggle of a few yards that it seemed an economy of both time and effort to walk even a mile around, rather than to attempt the straight and extremely narrow course. Where the trees are only a foot or two high, one can walk on their tops, but this is out of the question in trees four or five feet high; perhaps one might manage it with modified snowshoes!

To delve beneath those ancient trees - for 258 


\section{BLANC SABLON}

my former study of tree-rings on the Labrador coast assures me that many of these trees must be much over a hundred years old and may in some cases date back even to Cartier - is a difficult task, but one finds here a habitat in which forest plants are surely at home.

There was so much of interest in my journey inland on the first afternoon that I wandered less than a mile, but I had a most exciting ornithological experience, namely, the discovery of song sparrows. As far as I know, the only previous record by any one for the song sparrow in the whole Labrador Peninsula is at Lake Misstassini, and I have always had a lurking suspicion, probably erroneous, that there was a possibility of error in that record. Certainly there were no song sparrows along the coast we had traversed. Audubon did not find them and no observer has recorded them. There are only a very few records for Newfoundland. Cape Breton and the Magdalen Islands are generally supposed to be the northern limit on the eastern coast, yet here in this valley at Blanc Sablon I was startled by hearing the familiar song and soon saw several birds that were plainly song sparrows. It was interesting to find in the same 


\section{IN AUDUBON'S LABRADOR}

spot three closely related sparrows, - members of the same genus, - the song, swamp, and Lincoln's sparrows.

The next day I explored three miles to the eastward, to Anse Éclair. On my way back, I startled a pair of snipe, which rose uttering rough scaips, flew slowly a few yards with dangling legs, and dropped again into the grass. One of these I flushed again, and this time it dropped on mossy ground, where it lay on its side and fluttered its wings as if wounded. Young birds were doubtless concealed in the grass.

The following day I tramped seven or eight miles to the westward, to Long Point and Bradore. From Mr. Morrell's fishing-room the path leads up over the old terraces and seabeaches with occasional sand-dunes. The fog shut in so that I had no distant views, but near at hand there was plenty of interest - ornithological, botanical, and geological which gave me food for thought. In Shaler's Autobiography the following lines by his wife should apply to all naturalists: "It was impossible for one to be bored who sought, as he did, an explanation of the world about him. 


\section{BLANC SABLON}

... With the good earth beneath his feet and the light of heaven above, the ceaseless pulsing of the sea and the ancient rocks to tell their story, he found himself elated. In truth he was never lonely in company with his great friend and goddess, Nature."

Near the summit of the pass I came upon several redpolls, whose varied call-notes resemble closely those of both species of crossbills and those of the goldfinch. Their song is a series of high trills, and the birds were flying in irregular circles as they sang.

The little village of Acadian fishermen at Long Point is clustered about the low, rocky eminence on which stands the mission church of Notre Dame de Lourdes. This is presided over by Père Hesry. To him I paid my respects and with him I had interesting converse. His is the most eastern mission of the Eudist Brothers on this coast. He enjoys his life here among the fishermen, particularly his winter travel by komatic, but he is looking forward to seeing again the dear home country, to which he believes that all the banished religious orders will be welcome on the spiritual awakening after the war. He showed me with 


\section{IN AUDUBON'S LABRADOR}

great pride the new church he is building, as well as the old structure still in use.

After tearing myself away with an effort from the good priest's generous hospitality, I continued my solitary way and soon found myself among the interesting and familiar surroundings of sand-dunes, a region known here as Anse des Dunes. Outside was a white sand beach about a mile long, bordered by the palegreen strand wheat, which was growing luxuriantly. A harvest of grain might have been gathered here that would have filled many otherwise empty bread-boxes. The strand wheat extended back but a short distance into the dunes, growing scantier and smaller as it went, showing its dependence on the brine of old Ocean. The dunes were irregularly windcut and were about a mile wide, piled up in places to a height of fifty feet. Their formation was the same as in all dune regions, modified by the vegetation, which was here for the most part very different from that with which I was familiar on our New England coast. Closely matted carpets of curlew-berry, bearberry, oval-leafed blueberry, mountain cranberry, and alpine birch in places bound 


\section{BLANC SABLON}

the sand. Again there were somewhat thicker carpets of spruce and fir. But what I appreciated most in this desert region - features that I wished could be transported to my home dunes at Ipswich, Massachusetts - were the brooks of clear, cold water in which trout darted to and fro. Inland, beyond the dunes, were raised beaches of boulders, low cliffs, and again more terraces and raised beaches.

The path, which had been obscure among the dunes and often wiped out by the blowing sand, then led me over the higher land some distance from the sea, and I suddenly became aware of the fact that it was marked by what looked for all the world like cart-wheel ruts. Anywhere else I should have thought nothing of it, but here there were no carts and no horses, and, as far as I knew, the only animal of this description in all the region had lived and died some years ago at Natashquan, two hundred and fifty miles off. I tried to explain the phenomenon in various ways, but learned from Mr. Grant that these were in reality carttracks made many years ago by the horse and cart of the wealthy and famous Mr. Jones of Audubon's time. Vegetation is of slow growth 


\section{IN AUDUBON'S LABRADOR}

in these cold regions, and tracks of this sort take many years to obliterate. It reminded me of a discovery by some Arctic explorer of the tracks of a hand-cart at Melville Island made by Parry's men over eighty years before.

While I was pondering over these cart-tracks I perceived a dozen ravens on the plain ahead of me. Such a number of these birds together was new in my experience, and I was anxious to assure myself that my diagnosis was correct, and that they were not crows. Several flew near enough for me to see their characteristic fan-shaped tails, so different from the slightly rounded tail of the crow, but I wished to put the final stamp on their identity by hearing their voices. They were singularly silent as they flew away, but one was good enough to turn and fly directly towards me and say cra- $a-k, c r a-a-k$ instead of caw-caw, and then I was as sure he was a raven as if he had told me his name.

I planned my arrival at Bradore Bay so as to dine on the Sea Star, but, at the house of the captain's brother-in-law, Captain Blais, I learned that the whole company of the Sea Star - captain, first mate, cook, and bota- 


\section{BLANC SABLON}

nist - had gone back into the mountains for the day. Captain Blais, one of the splendid men of the coast, unfortunately for me had not yet arrived for the season. I was made welcome at his house, however, and, after a good lunch, returned to Blanc Sablon.

This was Friday night, and I signified my intention to the Grant family of giving up all ornithological work for the rest of the visit and of taking part in any variety of fishing occupation they might suggest. I did not, however, bind myself to shut my eyes and ears to birds, for this was impossible. I was at once taken possession of by the younger members of the family, who proposed to initiate me into the various branches of Labrador fishing. We were taken in a motor-boat that towed a "trap skiff" full of men out to haul cod-traps near Greenly Island. The cod-trap is a large box, as it were, made of nets suspended in the water by corks and cask buoys. At one corner is an opening, and here a net called a leader, some fifty yards long, connects it with the shore. The cod, swimming along the coast, strike the leader and at once turn to deeper water for safety and enter the trap, from which 


\section{IN AUDUBON'S LABRADOR}

they have not the intelligence to escape. Although it was six o'clock in the evening and the fog was so thick that we could not see the shore, on which we could hear the surf pounding only a short distance away, the light in this northern seashore region was so intense that I was able to photograph the men as they were drawing the nets.

The men begin at one side of the trap and haul the nets into the boat, crowding the fish in a quivering, struggling mass at the other side, whence they are scooped up into the boat or lifted up in the net. We had a small haul, only about three quintals of fish.

Saturday morning early we boarded the steam-trawler Tommie and started for the fishing-grounds. The captain, Sam Elder, had learned the business of gill-netting from my friend, Mr. Jere Campbell, at Gloucester. The net is about a fathom wide and is kept upright at the bottom of the sea by lead weights on the lower edge and metal cylinders filled with air on the upper edge. It is hauled up over the side of the boat by a steam-winch and it came up literally crowded with fish entangled by their gills and tails in the meshes of the net. 


\section{BLANC SABLON}

All were cod with the exception of a few dogfish - vicious-looking sharks much detested by the fishermen - and one or two strangelooking blue lumpfish. The men stood by and disentangled the cod from the net and pitched them into the hold, while the boss himself, Mr. Grant, was ready with a boat-hook to fish up the loosely attached cod that occasionally dropped back into the water. His efforts were skillful, but not always successful, and served to give a sporting flavor to this rather monotonous form of fishing. Every now and then an interesting starfish or other marine invertebrate would come up in the net, and I was able to make a collection of red seaweeds for a botanical friend at Harvard. We hauled three miles of net and secured fifteen quintals of fish.

On our return our ardent party of amateur fishermen again embarked, this time in a rowboat, and were towed by a motor-boat over towards Île au Bois. Here we were left to drift about for an hour or two and we entered into a competitive sport of "jigging" for cod. The "jig" is a bright piece of lead, somewhat of the shape of a fish, about six inches long, ter- 


\section{IN AUDUBON'S LABRADOR}

minating in two cod-hooks placed back to back. The fisherman lets this down until it touches the bottom, withdraws it a foot or two, and then proceeds to "jig." He stands erect in the boat and quickly draws the line from side to side over the gunwale of the boat as far as his arm can reach; the jig is then allowed to sink back and the process is repeated. A spurt of water follows the line; it is wet work and best done in oilskins. The cod are attracted by the glittering, quickly moving lead, and are liable to be hooked anywhere in their anatomy. We caught sixty-six fish and then started to row back, but the considerate "boss" sent out the Tommie to tow us in.

That afternoon it was proposed that the whole household should go for a picnic supper up to the waterfall of one of the small brooks that flowed down the terraces. A large fryingpan formed the chief part of the equipment, and I discovered that I was the only one to bring a fishing-rod. However, my task was an easy one and much pleasanter than jigging for cod. I stood on a little gravelly beach beside a deep pool just below the falls, and had the pleasure of finding that each of my casts, 



\section{BLANC SABLON}

no matter how unskillful, was greeted uproariously, so to speak, by the trout, who vied with each other for the distinction of hooking themselves. They seemed to like to jump from the water and seize the flies from above. In a short time I caught thirty trout, mostly halfor three-quarter-pounders, more than enough for all of us to eat. They were not wasted, however, and we took the remainder home for breakfast. Tea and trout, pie and "pork cake,"1 made a good supper, and were much enjoyed after our fishing day. It is true that it rained a little, and the black flies were so thick that a smudge was necessary. I had hardly noticed them in the excitement of fishing. Mr. Grant was the only one of the household missing on this picnic, but from our elevated position on the terraces we had seen him start out twice from the house, and each time unexpectedly return. He told us afterwards that the flies were too thick for him.

Sunday was a day of rest, rain, and fog with no chance of the arrival of the Meigle,

1 I have since learned that the "pork cake" of Labrador, made without eggs, milk, or butter, is the now well-known "war cake." 


\section{IN AUDUBON'S LABRADOR :}

and $I$ ate a big Sunday dinner, but not of the regulation kind. Dried capelin, rabbit, the big Northern hare canned in winter, boiled turnip-tops, and steamed blackberry pudding, all washed down with spruce beer. The pudding was made with curlew-berries, or blackberries as they are called here, and it was very good. In the evening there was service in the dried-fish storehouse, from the belfry of which rang the bell that in old times had summoned the fishermen to their daily grog. Mr. Edward Hunt, the young Church-ofEngland theological student from St. John's, who was spending the summer at the missions along the coast, read the service in an admirable manner. There were vigorous responses and hearty singing by the men.

On the afternoon of Monday, August 2, in one of the lucid intervals of the fog, the Meigle's horn was heard blowing, and I bade good-bye to my hospitable friends. I turned away from Labrador with very different feelings from those of Audubon, who recorded in his Journal, "Seldom in my life have I left a country with as little regret as I do this," - but he had not been visiting the Grants! 


\section{BLANC SABLON}

"Those hardy days flew cheerily, And when they now fall drearily,

My thoughts, like swallows, skim the main

And bear my spirit back again,

A wild bird and a wanderer." 


\section{CHAPTER XIII \\ CONSERVATION IN LABRADOR}

$\mathrm{N}$ the foregoing pages I have referred to the 1 great waste of natural resources that is going on everywhere along the coast of the Labrador Peninsula. It seems worth while to gather up the scattered threads and weave them in this chapter into a connected whole. It is possible that much could be done in the conservation of the chief industries of the coast - that the harvest of cod, salmon, halibut, herring, and capelin could be made more abundant and less uncertain from year to year by modern methods of fish-culture and fish-capture. There is no doubt that these fish could be utilized with less waste than at present. Cods' tongues, for example, now thrown away, could be canned and form a by-product of considerable value. The cods' livers are rarely so treated as to produce a high-priced medicinal oil. At most places along the coast the livers are thrown into barrels to rot and the resulting dark cod-oil 


\section{CONSERVATION IN LABRADOR}

is of inferior value and can be used only for commercial purposes. There is no reason why Labrador cod-liver-oil should not be as good and as famous as the Norwegian cod-liver-oil and command as high a price.

Capelin are small fish about the size of smelts and of considerable food-value. They school in enormous quantities on the coast; the water appears at times to be literally filled with this dark, almost transparent, fish, and they often pack together in great masses in the cod-traps or strand in shallow water. Owing to their abundance, they are not appreciated as they should be, but are generally cast aside or they are salted and dried so carelessly that large quantities spoil. Both fresh and dried they are excellent eating, but are generally considered only as food for dogs. As cod-bait they have few equals, but they may be absent at the critical time when they are needed. It would be very easy and inexpensive to provide cold-storage rooms packed with snow for capelin, which would be ready whenever bait was needed. A large export industry in dried capelin could also be built up as soon as the food-value and excellence of this fish were 273 


\section{IN AUDUBON'S LABRADOR}

generally known. As a smoked or canned product the possibilities are also large. Yet one sees many tons of this valuable fish destroyed and wasted along the coast.

Even such fish as flounders and dogfish, now thrown away, would be found of value. To one familiar with the excellence of the flounder as food it is a surprise to read, as I did in August, I9I5, an editorial in a St. John's paper calling the attention of the Newfoundlanders to the obvious fact that the flounder is an edible fish and should not be used as a fertilizer. Dogfish - small sharks - do great damage to the fishing-industries, as they eat the bait on the bultows or trawls, damage the nets, and destroy countless fish. They are taken out of the nets by the fishermen, knocked on the head, and thrown into the sea as worse than useless, but they are of considerable foodvalue, and are much appreciated by those who have tried them. Dogfish have large livers which are of value in the production of fishoil, and as a last resort these fish make excellent fertilizer. A considerable saving would result if the people of the coast should accustom themselves to the use for their own 274 


\section{CONSERVATION IN LABRADOR}

table of the cheaper but excellent fish, such as capelin, flounders, and dogfish, and should reserve the more valuable cod for export. These cheaper fish, if properly salted and dried, could also be stored away for winter use.

During the fishing-season the waters of the harbors are lined with tons of fish viscera, heads, and backbones, all rich in nitrogen and of great value as plant-food. As long ago as I 855 Lord Strathcona, then Donald Alexander Smith, discussed plans for the manufacture of fish manure. The annual product of the North American cod-fisheries was then estimated to be one and a half million tons of fresh fish.

He says: "Not less than one half of this is refuse thrown back into the sea, or left on the shore to decay, and yet capable of yielding I50,000 tons of a valuable manure, almost half that annually produced by Peru. . . . The waste of fish on this coast is enormous and is only comparable to the waste of buffalo in the Far West. Every ton of fish is equal to at least three head of cattle or fifteen sheep, and Labrador yields millions of quintals annually." 


\section{IN AUDUBON'S LABRADOR}

In 1884 the value of fish-guano produced in Nova Scotia amounted to over $\$ 22,000$, and, in New Brunswick, to over $\$ 43,000$.

The lobsters of the Labrador coast are of the best quality, and nowhere are better canned lobsters put up than in that region. The lobster-fisheries are wastefully managed. It would be difficult in these remote canneries to enforce a law against the use of "shorts," but I have always believed that a law requiring the lobster-pots to have an opening definitely limited in size would be practical and advantageous. All lobsters over a certain size would then be unable to enter the pots, and it is the large lobsters that are the most productive of their kind. Inspection of the lobsterpots would be simpler and easier than inspection of the catch.

The appalling wastes that are a part of the present methods of spring sealing on the ice can only be mentioned here. Every year tens of thousands of seal-carcasses are stripped of their hides and fat and abandoned in the same way that the carcasses of the buffalo, destroyed for their tongues and their hides, were abandoned in the West. As a result, the same 


\section{CONSERVATION IN LABRADOR}

fate that befell the buffalo awaits the seal. In addition to this waste, many thousands of the seal-pelts are lost annually by the breakingup of the ice before they can be placed on board the sealers. This is expected; chances must be taken, for the slaughtering competition is keen. Even in the shore fisheries the meat is often wasted, or, if saved, is given to the dogs. As I have said, it is a meat of pleasant flavor, tender, and of great food-value for human consumption. Stores of seal-steaks packed in snow for the winter, and drawn on from time to time, would supply plenty of excellent proteid food and prevent beri-beri and scurvy along the coast.

The uncertainty and waste in the trapping of fur-bearing animals is a strong argument in favor of the raising of these animals in captivity. The climate is well adapted to the purpose, and the fur, in consequence, is of the best quality. The starting of a black fox ranch is expensive. Even if a poor man is fortunate enough to catch a black fox alive, he cannot afford to run the risk of its loss in captivity, and must sell it as soon as possible. There is, however, a profit in the raising of red 


\section{IN AUDUBON'S LABRADOR}

foxes and various other fur-bearing animals without so much initial expense and without the risk of so much loss. Experiments in minkraising have recently been made by the Biological Survey of the United States Department of Agriculture, and their success for commercial purposes is reported. The animal is polygamous and breeds rapidly at the age of one year, and its fur is marketable at a year and a half. It can be fed the same food as is given a cat. Many Labradorians, to whom black fox farming seems entirely beyond their reach, would, with a little instruction and encouragement, welcome such a means of livelihood. There are doubtless other fur-bearers that could profitably be reared in captivity for their skins. Muskrats are extremely prolific, and the black form, which is occasionally found in Labrador, has a fur of great beauty and considerable value. The raising of furbearing animals need not in any way interfere with the principal industry of the coast, - namely, cod-fishing, - for its chief duties would occupy the people during the long winter when there is least to be done; in the summer the women and children could care for the 278 


\section{CONSERVATION IN LABRADOR}

animals when the men were engaged in fishing. If the dogs were replaced by reindeer, - a consummation devoutly to be wished, and a subject I have already discussed, - the food formerly used for them would be available for carnivorous fur-bearing animals.

It is probable that agriculture on a large scale will always be unprofitable on the Canadian, and still more on the Newfoundland, Labrador coast. The soil is scanty and poor, often entirely absent; the summer season is short and liable to interruption by frost at any time. The earliest green leaf to unfold is that of the wild currant, and at Esquimaux Point in I909 I found the first currant leaf on May 26. Cartwright, in I77I, at Cape Charles records the first currant leaf on May 2I. Ice often lingers along the shores of the eastern part of the southern coast into July, and by the latter part of August autumn is in the air. Nevertheless, there is no doubt that with careful selection of short-season species of food-plants, such as have been introduced so successfully, after government experimentation, in Alaska, agriculture, to a limited but very important extent, might flourish here. 


\section{IN AUDUBON'S LABRADOR}

The Government of the Province of Quebec has already made some effort to show the people how this may be done. The river-valleys but a short distance from the sea not only have a much milder climate, as is shown by the forests and the bird-life, but often contain an abundance of fertile soil in natural meadows. Thorough drainage operations would convert large areas of bog into arable land and at the same time rid these places of the pest of mosquitoes. In the Amur district in Siberia similar bog country has been made productive even in regions where the ground is permanently frozen to a great depth. ${ }^{1}$

The gardens of Mr. Morrell at Blanc Sablon, of the Eudist fathers at Natashquan, and of M. Johan Beetz at Piashte Bay, described in these pages, are examples of what can be accomplished directly on the coast. Even so long ago as the eighteenth century, Captain George Cartwright set an example which might well be imitated by the Labradorians of to-day. He not only raised in his house in winter cress and mustard as a salad and preventive of scurvy, but he made many careful

1 See Through Siberia, by Fridtjof Nansen. 


\section{CONSERVATION IN LABRADOR}

experiments in garden-growing and in the use of fish-refuse and seaweed as fertilizers. He says: "My garden in Isthmus Bay, which, the reader would observe, produced excellent crops the first year, by being manured with seaweed and offals of fish; and also by mixing a greater portion of the barren sand that lay underneath, among the peat soil on the surface, it has since, I have been informed, brought everything to a degree of perfection, which had never been seen in that part of the world, in any former year." 1 Isthmus Bay is on the eastern coast near the entrance of Sandwich Bay, where the climate is much more severe than in the Canadian Labrador.

The natural luxuriant growth of strand wheat along the sandy shores shows what can be done if proper plants are chosen. In Iceland the grain of the strand wheat is used in making bread. I cannot insist too strenuously on the importance of using some other cereal food than the universal finely bolted white flour. Dr. John Mason Little, Jr., ${ }^{2}$ has shown

1 Captain Cartwright and his Labrador Journal (I909), p. 360.

2 Journal of the American Medical Association (1912), vol. 58, p. 2029. 


\section{IN AUDUBON'S LABRADOR}

that, as the exclusive use of polished rice in Japan is productive of beri-beri, so the same disease is caused in Labrador by the use of white flour. I was interested to find in my trip up the Natashquan River in I9I2 that the men were much pleased with my supplies of Indian meal and brown rice. They had never tasted them before, and, to my surprise, preferred them to the white flour, which was almost untouched.

Many miles farther north in Labrador, at the North-West River Post of the Hudson's Bay Company, the enterprising Donald Alexander Smith, in the fifties and sixties of the last century, made a model farm on an extensive scale. The trappers and fishermen, who at first scoffed, were later filled with astonishment and admiration. Seed, poultry, and hardy cattle he obtained from the Orkneys, horses and sheep from Canada. The soil he enriched with fish-offal, and he cultivated seven acres, some of which was under glass.

For fertilizers decayed seaweed and fishrefuse are both excellent and ready at hand. It has been supposed that guano could be obtained in Labrador from the islands where the 


\section{CONSERVATION IN LABRADOR}

sea-birds breed, but this is not the case. The frequent rains and the freezing and thawing prevent the accumulation such as is found in dry climates like that of Peru.

The water-power of the country is enormous and the possibilities in the production of wood-pulp are great. It is sincerely to be hoped that the proper forestry restrictions will be placed on the latter industry, as is now voluntarily done at Clark City in the Bay of Seven Islands, and that the country will not be ruthlessly stripped and left a rocky desert.

As regards mineral wealth, there are serious doubts as to its existence in paying quantities in the Labrador Peninsula.

But what lies nearest to my heart is the subject of bird-conservation, which is so sadly needed on the coast of Labrador. In the latter part of the eighteenth century, in the time of Cartwright, water-birds swarmed along the coast. The Eskimos and the Indians, the polar bears and the raptorial birds, served but to keep the bird-colonies in healthy condition. The white man is more systematic in his methods and more thorough when he is stimulated by the expectation of financial gains, and, 


\section{IN AUDUBON'S LABRADOR}

if conservation is not practiced, he will eventually exterminate the creatures of his quest. This was true in the case of the buffalo, the great auk, and the passenger pigeon, and the same fate awaits many other beasts and birds. In Audubon's day the despoilers of Labrador bird-rookeries plied their trade without let or hindrance. Audubon was filled with sorrow on observing their cruel methods and their ruthless destruction of his beloved bird-life. $\mathrm{He}$ writes:-

"See yon shallop, shyly sailing along; she sneaks like a thief wishing, as it were, to shun the very light of heaven. Under the lee of every rocky isle some one at the tiller steers her course. ...

"There rides the filthy thing! The afternoon is half over. Her crew have thrown their boat overboard, they enter and seat themselves, each with a rusty gun. One of them sculls the skiff towards an island for a century past a breeding-place of myriads of Guillemots, which are now to be laid under contribution. At the approach of the vile thieves, clouds of birds rise from the rock and fill the air around, wheeling and screaming over their enemies. Yet 284. 


\section{CONSERVATION IN LABRADOR}

thousands remain in an erect posture, each covering its single egg, the hope of both parents. The reports of several muskets loaded with heavy shot are now heard, while several dead and wounded birds fall heavily on the rock, or into the water. Instantly all the sitting birds rise and fly off affrighted to their companions above, and hover in dismay over their assassins, who walk forward exultingly, and with their shouts mingling oaths and execrations. Look at them! See how they crush the chick within its shell, how they trample on every egg in their way with their huge and clumsy boots. Onward they go, and when they leave the isle, not an egg that they can find is left entire. The dead birds they collect and carry to their boat. ...

"The light breeze enables them to reach another harbor a few miles distant, one which, like the last, lies concealed from the ocean by some other rocky isle. Arrived there, they re-act the scene of yesterday, crushing every egg they can find. For a week each night is passed in drunkenness and brawls, until, having reached the last breeding-place on the coast, they return, touch at every isle in suc- 


\section{IN AUDUBON'S LABRADOR}

cession, shoot as many birds as they need, collect the fresh eggs, and lay in a cargo. At every step each ruffian picks up an egg so beautiful that any man with a feeling heart would pause to consider the motive which could induce him to carry it off. But nothing of this sort occurs to the egger, who gathers and gathers until he has swept the rock bare. The dollars alone chink in his sordid mind, and he assiduously plies the trade which no man would ply who had the talents and industry to procure subsistence by honorable means."

Mr. M. Abbott Frazar in 1884 was much impressed with the destruction of bird-life by the fishermen. He says: "During the week the men are all busy out in their dories fishing, but their Sundays are their own and are generally spent on the islands gathering eggs and shooting birds, and they stop at nothing, but shoot everything that flies whether eatable or not, and shoot just for the sport they find in destruction; and as they keep it up during the whole season the poor birds have but a slim show." He also saw a few Halifax eggers on the coast. 


\section{CONSERVATION IN LABRADOR}

Mr. D. N. Saint-Cyr ${ }^{1}$ visited the Canadian Labrador coast in I882 and I885. He says: "It is unfortunately too true that certain settlers on the coast, but more especially strangers, from Nova Scotia, from the State of Maine, and the Island of Newfoundland, pillage the sea-birds' eggs, which they carry off to sell in their own country. These years past as many as thirty schooners have been counted, engaged in obtaining loads of wild birds' eggs in the islands of the gulf, and, to make matters worse, when these pillagers observe that the eggs are hatching, they break them, in order that the old birds may lay more. Then all these fresh eggs are taken away, and it is thus that thousands upon thousands are destroyed every year."

The visits of the Halifax eggers for commercial purposes have long since ceased, but the robbery of eggs and the destruction of nesting birds still continue. The conditions as I found them on my four trips to the Labrador Peninsula, which have included a survey of eleven hundred miles of the coast from the Bay of Seven Islands to Nain, are most

1 Sessional Papers, No. 37. (Quebec, 1886.). 


\section{IN AUDUBON'S LABRADOR}

deplorable, and are rapidly leading to the utter extinction of the water-birds. Spring shooting confined to migratory birds, although undesirable, is not so pernicious in its effects as the shooting of birds on their arrival at their breeding-grounds. This is practiced in the case of all the birds that nest on the coast. At Perroquet Island, in Bradore Bay, for example, the arrival of the puffins or perroquets in the spring is eagerly awaited by the inhabitants, who make the occasion a great shooting holiday. They encamp for several days on the island and shoot down the poor birds as they fly in a bewildered manner round and round their homes. I was told by one man with great glee that he sometimes shot two hundred birds in a day. He added that the wounded birds were generally lost, as they crawled into the nesting-holes.

I myself in I909 witnessed, on another island where puffins bred, this cruel sport. The birds, bewildered and frightened by the shooting, circled about the island, and were picked off by the gunner as they flew past. At Perroquet Island the boys who have no guns lie behind the rocks and strike down the birds with long 288 


\section{CONSERVATION IN LABRADOR}

poles. The whole village feasts on the puffins and many are wasted or given to the dogs. Throughout the summer the island is visited by fishermen, who not only shoot the birds, but also dig them out of the nesting-holes and secure them in nets spread over the holes. In any case the young are left to perish. The Newfoundland fishermen are undoubtedly the worst offenders in egg and bird destruction, but the people of the coast are not far behind. The former are absolutely regardless of consequences for the birds, but the people of the coast in some few cases are careful not to disturb the birds after the first eggs have been appropriated. The cases related in Chapter vi of the island near Pointe au Maurier, where ring-billed gulls breed, is an example. Here for many years the sole family living at this place have been in the habit of looking to the island for a supply of fresh eggs, but they never disturb the birds after the first set of eggs has been taken. The bird-colony has in consequence suffered no diminution, and has even increased in numbers.

The shooting of female eider ducks as they leave their nests involves, of course, the loss of the broods. The eggs themselves may be dis- 


\section{IN AUDUBON'S LABRADOR}

carded on account of the advanced stage of incubation. The fishermen take the eggs to a pool of water and save only those that sink. The ones that float contain partly or wholly formed young and are thrown away. If the men intend to stay near the breeding-place for a few days, they destroy all the eggs so that a fresh lot may be laid for them to appropriate.

Nesting murres and auks are shot or killed with clubs. Most of these birds are eaten, but nesting gulls, terns, and cormorants are often shot for the cruel pleasure and practice of the sport and left where they fall. It is almost inconceivable that men should destroy such exquisite creatures as terns and gulls without even intending to pick them up and look at them, and it is a sad commentary on humanity that such "sport" - God save the mark! - is not infrequently indulged in by men of education and supposed refinement. I have known men of this class to hold up their hands in horror at an ornithologist who had shot a small bird for the distinct object of study and of addition to human knowledge. Another cruel sport that is frequently practiced by thoughtless people is the firing of guns near rookeries 


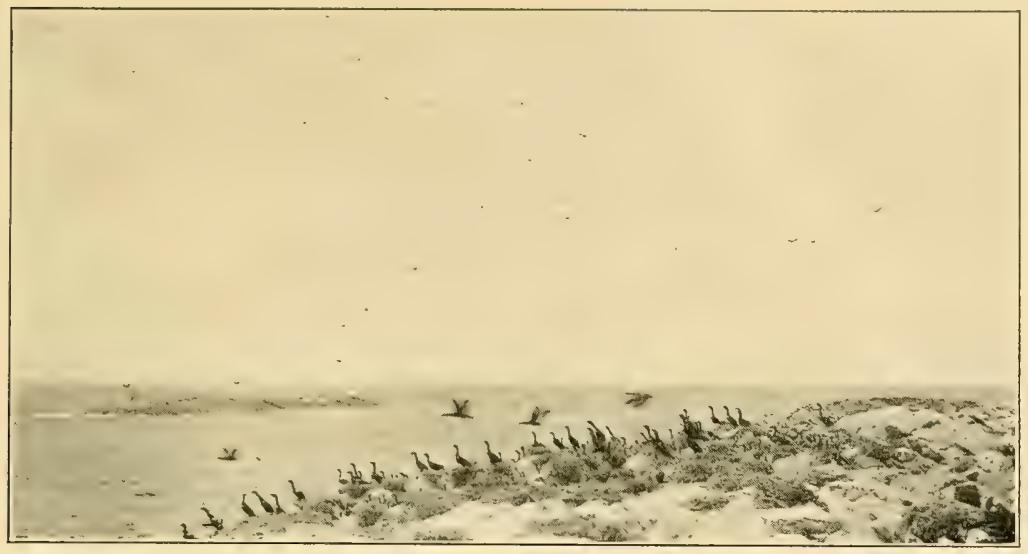

DOUBLE-CRESTED CORMORANTS LEAVING THEIR NESTS AT GULL ISLAND OFF CAPE WHITTLE



DOUBLE-CRESTED CORMORANTS AND MURRES 



\section{CONSERVATION IN LABRADOR}

for the purpose of seeing the frightened birds jump from their eggs. As a result the cliffs of Cape Whittle are now nearly deserted by birds.

I obtained from reliable sources, often from the offenders themselves, who seemed to be entirely unconscious of the enormity of their offenses, numerous reports of great quantities of murres' and eiders' eggs collected for their own consumption by the crews of fishing and trading schooners. Many of these vessels are scantily or poorly provisioned and make up for this by inroads on the birds. Up to a few years ago a dozen barrels of murres' eggs have been collected by a crew of twenty men in less than an hour from one island. As many of the terrified nesting birds are clubbed and killed as possible. The manner in which bird-life is squandered at such times is almost too terrible to be thought of.

Besides the eggs and nesting birds, the young of several species of water-birds, particularly of the great black-backed gull, are eagerly sought for the table. Sometimes the young are confined in coops and fattened before killing. The fact that this gull sometimes destroys young 


\section{IN AUDUBON'S LABRADOR}

eiders and the eggs of nesting birds is often seized upon by these men as an excuse for destroying both old and young of this species, but the majority seek no excuse.

The recent adoption and increasing use of motor-boats has greatly increased the destruction of birds. Fishermen are enabled to traverse much greater areas of the coast, to reach distant islands where birds are nesting, and more readily to approach birds on the water. Going to and from the fishing-ground, the motor-boat enables its owner to take wide détours and gather cargoes of eggs and nesting birds. When sails and oars are used, these outof-the-way spots are fairly safe.

The destruction wrought by the Indians during their summer sojourn on the coast is increasing as other sources of food are diminishing.

If the treatment of the bird-population in Canadian Labrador, where there are laws and game-wardens, is bad, that in Newfoundland Labrador, where there appear to be neither, is still worse. In I906 I found a bad state of affairs ${ }^{1}$ and a rapidly diminishing water-bird

1 See Along the Labrador Coast, chap. XI, "Audubon and the Need of an Audubon Society in Labrador." 


\section{CONSERVATION IN LABRADOR}

population. Mr. A. C. Bent, who visited this coast in the summer of I9I2, says: "I had heard that the sea-birds on the Labrador coast were disappearing, but was not prepared to find them so scarce as they proved to be. They seem to have decreased very decidedly during the past few years, and, unless something can be done to protect them, many species will soon have disappeared entirely. Their nests are robbed frequently all through the summer by the resident white people, by the Eskimos, and by the large number of Newfoundland fishermen that visit the coast in the summer. The birds are also shot freely for food at all seasons of the year." 1

The whole outlook is, indeed, a gloomy one. It was thoroughly understood by Audubon in I833. He says: "Nature herself seems perishing. Labrador must shortly be depeopled, not only of aboriginal man, but of all else having life, owing to man's cupidity. When no more fish, no more game, no more birds exist on her hills, along her coasts, and in her rivers, then she will be abandoned and deserted like a wornout field."

1 Bird-Lore (I9I3), vol. xv, p. II. 


\section{IN AUDUBON'S LABRADOR}

It is an old custom, and the wastefulness and 'terrible cruelty of it all does not appear to penetrate to those men's consciences. The people who live along the coast and the fishermen who come from a distance have always been in the habit of taking eggs and killing the birds for food. They regard it as their right, and, although some of them will admit that the wasteful methods used are fast destroying the birds, they are not willing to refrain from these methods. They say, with reason, that if they do not take these eggs or young gulls or shoot these nesting ducks some one else will. It is each man for himself and the devil take the hindermost. After us the deluge. Annihilation is the fate of the birds: the eider and the murre will go the way of the Labrador duck and the great auk. Birds that nest in crevices in the rocks, like black guillemots and razor-billed auks, will last longer, but the end is in sight for all.

It is a truism that laws out of sympathy with the feelings of people will not be kept. Laws against egging or shooting out of season cannot be enforced on the long and intricate coast of Labrador. Wardens who intend to do their duty and arrest and prosecute offenders will 294 
be looked upon as enemies to be avoided and cheated, and this by an otherwise law-abiding people.

There is one very simple means which might help in enforcing the present laws in Canadian Labrador. Newfoundland fishermen, who are the most reckless offenders, are obliged to obtain licenses to fish in Canadian waters. The law requires that they not only obey the game laws, but that they also take out at some expense licenses to carry guns and shoot. If the presence of an unlicensed gun on a fishingschooner or the detection in egging be made a sufficient reason for canceling the fishinglicense, one of the great sources of bird-destruction will be diminished, but not by any means stopped. It is easy to conceal guns and elude wardens on this coast.

The open season for shooting should be intelligently planned for different parts of the coast and should be strictly limited to the periods when the birds are migrating. It is, of course, illogical to have the same open season at Blanc Sablon as at Nain where birds nest several weeks later. These suggestions if adopted may be of some value, may delay for a little the 


\section{IN AUDUBON'S LABRADOR}

rapid progress towards annihilation of waterbird life in Labrador. That these or any similar measures will prevent this dreaded consummation I do not believe.

What, then, is to be done? Is there no hope for the birds and for the people to whom the birds are such a valuable asset? I think there is. I believe that the whole problem can be solved most rationally and satisfactorily for all concerned by the immediate establishment of bird reservations. These should be islands or groups of islands or suitable portions of the main coast that can be watched by guardians. Here the birds should be undisturbed and allowed to nest and feed in peace. The people should be made to understand that these reservations are not established to cut down their hunting, and thereby invite poaching and violation of the laws, but for the purpose of preserving and increasing the birds so that there shall be better shooting for everybody on the coast.

A campaign of education is necessary, therefore, and I believe that the bird reservation will do good in making the people understand not only the need of bird-conservation, but its advantages. The game-wardens will be looked 
upon, not as enemies to be avoided and cheated, but as friends who are working for the people's good. If the matter is well managed, the people will regard their reservations with pride, and public opinion will keep the birds there inviolate. The wasted regions near fishing-villages, now devoid of all sea-bird life on the one hand, and the crowded bird reservations on the other, will be powerful object-lessons in this process of education. I would suggest the placing of a brief notice on each reservation, printed in English, as well as in French, Montagnais, and Eskimo, where these languages are used, worded somewhat as follows:-

\section{BIRD RESERAVTION}

The purpose of this Reservation is to preserve the birds from destruction and to increase their numbers so that there will be better shooting on the coast. The people are asked not to disturb the birds or their eggs on this Reservation and to avoid the use of guns in its neighborhood.

There are a number of places that could be named, some of which have responsible men living near who could be made guardians. For example, on the Canadian Labrador coast I would suggest one of the islands at the mouth of the Bay of Seven Islands; the Perroquet 


\section{IN AUDUBON'S LABRADOR}

Islands off Long Point, Mingan, where the lighthouse-keeper could be put in charge; SeaCow Island and the small islands in its neighborhood, near Esquimaux Point; an island at Betchewan; one at Piashte Bay; one or two at Natashquan; a strip of the sandy shore near the lighthouse at Natashquan Point; Triple Island off Romaine; Outer and Gull Islands and the cliffs of Cape Whittle; Gull Island at Pointe au Maurier where the interesting colony of ringbilled gulls breed; St. Mary's Islands with their lighthouse; one of the Harrington group of islands; Treble Hill Island and Flat Island off Great Mecattina; some of the islands of Kecarpoui and islands near Shecatica and Old Fort; and lastly, and very important, the famous Perroquet Island in Bradore Bay. On the Newfoundland Labrador similar scattered reservations should be made. These scattered reservations are, it seems to me, more important and more easily kept sacred than large ones such as the sixty-four miles of coast between Cape Whittle and Mecattina suggested by Colonel William Wood in his admirable address in I9II on "Animal Sanctuaries in Labrador." 


\section{CONSERVATION IN LABRADOR}

Some of these islands are now nearly depopulated of birds, but the birds can be trusted to find out where they are safe. On the coast of the United States where reservations have been established, sometimes close to great cities, the birds that are elsewhere very shy and wary are tame and confiding. I would also suggest that the guardian of the reservation be instructed in the eider-down industry as detailed in the next chapter, and that a beginning of this industry be made on the reservations both to eke out the small stipend of the guardian and as an objectlesson to the people.

If the reservation movement is well managed so that the people are in sympathy with it, it will be a success and one may look forward to many benefits as a result. First and fundamentally, the birds will be saved from extinction. This fact may not appeal to the people, but the improvement in the shooting during the migrations will be welcomed as a great boon. The introduction of the eider-down industry, which I believe will follow the reservation movement, should add a large sum yearly to the income of the people of the coast. Another desirable result of the reservations will be to make 


\section{IN AUDUBON'S LABRADOR}

the coast more attractive to tourists in general and to ornithologists in particular, and they will help the people in several ways. They will necessarily spend money along the coast, will introduce better transportation facilities, and new and better ideas of living. To ornithologists everywhere it will be an enormous relief to know that the great destruction of bird-life, so vividly portrayed by Audubon, is at last stayed and the wonderful bird-nurseries of Labrador are again assuming their rightful function. 


\section{CHAPTER XIV}

A PLEA FOR THE CONSERVATION OF THE EIDER ${ }^{1}$

$7 \mathrm{HE}$ treatment of that magnificent duck 1 the eider (Somateria dresseri) along our Atlantic coast is rapidly leading to its extermination. This duck, which is locally known as sea duck, laying duck, shoreyer, Eskimo duck, moynak, and metic, is everywhere diminishing in numbers. In Maine they were at one time reduced to a few pairs, but, by enforcement of laws and by reservations watched over by wardens, they are beginning to increase. I believe there are only two or three cases of their breeding at the present time on the Nova Scotia coast. On the Newfoundland coast their numbers are pitifully few where once they abounded. The coast of Labrador formerly swarmed with these birds, and the islands were thickly covered with their nests. All the ornithologists from the time of Audu-

1 Read at the meeting of the American Ornithologists" Union, November II, I9I3, and reprinted by permission from The Auk (1914), vol. xxxr, p. 14. 


\section{IN AUDUBON'S LABRADOR}

bon to the present day who have visited this coast have bewailed the fact that the eider was singled out for destruction.

In 1906 Dr. G. M. Allen and I saw only about seventy of these birds on the long stretch of the eastern coast of Labrador between Battle Harbor and Hamilton Inlet. This is a region that is visited by a large number of Newfoundland fishermen in summer, and its coast is dotted with the fishing-hamlets of the residents, or liveyeres, as they are called. The men know every nook and cranny of the coast, shoot the birds in great numbers in both fall and spring migrations, take their eggs and down whenever they find them, and even shoot the setting females. In visiting their fishingtraps in the height of the breeding-season they often take their guns along with them, so that few birds escape. North of Hamilton Inlet the Northern eider (Somateria mollissima borealis) is persecuted by the Eskimos of the Moravian villages as well as by the fishermen.

The same condition of affairs exists on the southern coast, where eiders are persecuted not only by the white fishermen, but also by the Montagnais Indians, who, after disposing 
of their furs, the result of their winter's work, cruise along the coast in sailboat and canoe and feast on the eider eggs and flesh.

In $1909 \mathrm{Mr}$. A. C. Bent and I found the ground about the Indians' encampments covered with eider egg shells, and we saw eider flesh being dried and smoked by the fires. Two men, who were ranging over the islands with pails, had collected a hundred eggs in less than an hour's time. William Brewster described the method used by these Indians in I88I: "They skirt the shores in canoes, keeping as close to land as the depth of water will permit. Meanwhile their dogs scent about among the trees quartering the ground like trained setters, and when a nest is discovered announce the fact by loud barking. The nests are usually within a few rods of the water, and the scent of the dogs is so keen that they rarely pass one. If the sitting bird can be caught or shot the opportunity is seldom neglected, for the halfstarved Indian neither knows nor respects considerations of mercy, or, perhaps we should call it policy, - which restrain more enlightened sportsmen on such occasions. Proceeding thus two men in a canoe will frequently ran- 


\section{IN AUDUBON'S LABRADOR}

sack twenty miles of coast-line in a single day and find, probably, nearly every eider nest. The result of this systematic persecution cannot be doubtful or long delayed."

M. Abbott Frazar, who was in southern Labrador in 1884, said of this bird: "They are persecuted with relentless energy by both man and beast from the time they arrive up to the time they leave, and the countless hoards that once inhabited this coast are fast disappearing, and it will not be long before the Eider of Southern Labrador, like the Eider of Grand Manan will be but a memory of the past."

It is natural that the fishermen and Indians should act thus, for eider eggs are delicious eating and the flesh of the birds, at least of the female and young, is equally palatable. Both are generous in the amount of nourishment furnished. But these people are killing the goose that lays the golden egg, and the time is not far distant, where such methods prevail, before the eider will be no more.

There is no reason why the eider, which furnishes the valuable eider-down of commerce, should not be made a source of consid304 


\section{CONSERVATION OF THE EIDER}

erable income, without any reduction of its natural abundance. The principle of conservation can as well be applied to the eider as to a forest. The conservation of the common eider of Europe (Somateria mollissima), a species that differs but very slightly from the American bird, has been practiced for many years in Iceland and Norway. The birds are rigidly protected during the nesting-season and offered every encouragement. They are not allowed to be shot, and even the discharge of a gun in their vicinity is forbidden by law. Suitable nesting-sites are furnished close to the houses and the birds become semidomesticated, losing all fear of man. The people are allowed to take the eggs and down during the first of the season, but the birds are permitted to hatch out and rear a few young in order to keep up the stock. The last down is taken after the birds have left.

The following quotations from various authors show what can be done in the conservation of the eider and what a profitable and pleasant business it may be made: "A person," says Horrebow, " "as I myself have wit-

1 Quoted by Nuttall. 


\section{IN AUDUBON'S LABRADOR}

nessed, may walk among these birds while they are sitting, and not scare them; he may even take the eggs and yet they will renew their laying as often as three times." "According to the relation of Sir George Mackenzie, ${ }^{1}$ on the 8 th of June at Vidöe, the Eider Ducks, at all other times of the year perfectly wild, had now assembled in great numbers to nestle. The boat, by which they approached the shore, passed through multitudes of these beautiful fowls, which scarcely gave themselves the trouble to go out of the way. Between the landing place and the Governor's house, the ground was strewn with them, and it required some caution to avoid treading on the nests. The Drakes were walking about uttering a sound very like the cooing of Doves, and were even more familiar than the common Domestic Ducks. All round the house, on the garden wall, on the roof, even in the inside of the house, and in the chapel, were numbers of Ducks sitting on their nests. Such as had not been long on the nest generally left it on being approached; but those that had more than one or two eggs sat perfectly quiet, suffering us to touch them

1 Travels in Iceland, p. I26. (Quoted by Nuttall.) 
and sometimes making a gentle use of their bills to remove our hands."

Baird, Brewer, and Ridgway quote from C. W. Shepard, as follows: "The islands' of Vigr and Oldey are their headquarters in the northwest of Iceland. In these they live in undisturbed tranquillity. They have become almost domesticated, and are found in vast multitudes, as their young remain and breed in the place of their birth. As the island (Vigr) was approached, we could see flocks upon flocks of the sacred birds, and could hear them cooing at a great distance. We landed on a rocky, wave-worn shore. It was the most wonderful ornithological sight conceivable. The Ducks and their nests were everywhere. Great, brown Ducks sat upon their nests in masses, and at every step started from under our feet. It was with difficulty that we avoided treading on some of the nests. On the coast of the opposite shore was a wall built of large stones, just above the high-water level, about three feet in height, and of considerable thickness. At the bottom, on both sides of it, alternate stones had been left out, so as to form a series of square compartments for the Ducks to nest in. 


\section{IN AUDUBON'S LABRADOR}

Almost every compartment was occupied, and as we walked along the shore, a long line of Ducks flew out, one after the other. The surface of the water also was perfectly white with Drakes, who welcomed their brown wives with loud and clamorous cooing. The house itself was a marvel. The earthen walls that surrounded it and the window embrasures were occupied by Ducks. On the ground the house was fringed with Ducks. On the turf slopes of its roof we could see Ducks, and a Duck sat on the door-scraper. The grassy banks had been cut into square patches, about eighteen inches having been removed, and each hollow had been filled with Ducks. A windmill was infested, and so were all the outhouses, mounds, rocks, and crevices. The Ducks were everywhere. Many were so tame that we could stroke them on their nests, and the good lady told us that there was scarcely a Duck on the island that would not allow her to take its eggs without flight or fear. Our hostess told us that when she first became possessor of the island the produce of down from the Ducks was not more than fifteen pounds in a year, but that under her careful nurture of twenty 308 


\section{CONSERVATION OF THE EIDER}

years, it had risen to nearly a hundred pounds annually. Most of the eggs were taken and pickled for winter consumption, one or two only being left in each nest to hatch."

Burton, writing in $1875,{ }^{1}$ says that not even a salute was permitted to be fired at Reykjavik for fear of frightening the eider, which was there a "barn-door bird" and as "tame as horse-pond geese." He says "the turf is shaven and hollowed to make the nests - and the places are marked by pegs."

Slater ${ }^{2}$ says of the common eider that it is "resident in large numbers; especially abundant round the coast, strictly preserved by law, and in consequence very tame. In Akureyri, for instance, the old ducks with their ducklings feed along the edge of the fjord quite close to the houses and road, and take no more notice of the passers-by than domestic ducks would do - which is very pretty. In winter they pack in immense flocks. The eider-down is, of course, the property of the owner of the land, and every inducement and protection is given to the birds, as the down

1 Ultima Thule, or A Summer in Iceland.

2 Manual of the Birds of Iceland. (190r.)

309 


\section{IN AUDUBON'S LABRADOR}

is a valuable article of trade." Bernhard Hantzsch ${ }^{1}$ says: "In consequence of the special protection which man everywhere exercises over them their numbers seem slowly to increase."

Nelson Annandale ${ }^{2}$ says: "The one offense against the Icelandic bird-laws which a native cannot commit with impunity is the slaughter of the eider-duck.... What is more important than many laws, namely public opinion, protects the species, and there seems to be a sentimental interest in it.... Probably it is due to the great tameness of the bird, which appears actually to seek the vicinity of a human dwelling for its nesting place and to frequent those parts of the coast which are more frequented by man.... The Icelandic eiderfarms are frequently situated on little islands off the coast. Small circular or oblong erections of rough stones are made among the hummocks, to protect the brooding ducks from wind and driving rain.... All the seafowl in these farms become exceedingly tame, as no gun is allowed to be fired and every thing lia-

1 Beitrag zur Kenntniss der Vogelwelt Islands. (1905.)

2 The Faroes and Iceland. (I906.) 
ble to disturb the ducks is carefully banished. Those who know how to handle them can even stroke the backs of the ducks as they sit on their eggs.... On such farms there is a separate building or large room entirely devoted to cleaning the down. The apparatus consists of a series of oblong wooden frames, which may be either fixed in a horizontal position or held in the hand. Their number and size varies greatly, but in all cases the principle is the same, depending on the tenacity with which the down clings to anything on which it is thrown, partly because of its lightness and partly because of the structure of the individual feathers which compose it. Along the frames are stretched rather loosely, a number of strings which may be either of twine or of thongs of leather. The down is cast onto these near one end, and a spatula of wood or bone drawn briskly backwards and forwards over the other end. The down still clings to the strings, but all impurities, such as pieces of seaweed or grass, small stones, or coarse feathers, fall through to the ground."

Newton ${ }^{1}$ says: "Generally the eggs and

1 Dictionary of Birds. (1893-96.) 


\section{IN AUDUBON'S LABRADOR}

down are taken at intervals of a few days by the owners of the 'Eider-fold,' and the birds are thus kept depositing both during the whole season; but some experience is needed to insure the greatest profit from each commodity. Every Duck is allowed to hatch an egg or two to keep up the stock, and the down of the last nest is gathered after the birds have left the spot. The story of the Drake's furnishing down, after the Duck's supply is exhausted, is a fiction. He never goes near the nest." Annandale ${ }^{1}$ says: "It was formally the custom to take away all the down supplied by the female; but this practice was said to lead to great mortality among the ducks through exhaustion and nowadays each nest is generally rifled only once before the eggs are hatched, and then again after the young have left it."

The same conservation of the eider exists in Norway. Stejneger ${ }^{2}$ says: "All along the coast of Norway, where the bird is protected by law throughout the year, the common eider (Somateria mollissima), is now exceedingly common and very tame. The inhabitants take

1 Op. cit.

${ }^{2}$ Riverside Natural History. 
great care of the breeding birds, which often enter their houses to find suitable nestingplaces, and cases are authenticated in which the poor fisherman vacated his bed in order not to disturb the female eider, which had selected it as a quiet corner wherein to raise her young. In another place the cooking of a family had to be done in a temporary kitchen as a fanciful bird had taken up her abode on the fireplace."

When St. Cuthbert, that holy man, went to live a lonely life on Farne Island, he tamed the eiders and they are called St. Cuthbert's ducks even to this day.

Eider-down is not only extremely light and elastic, but is also one of the poorest conductors of heat. It is therefore an ideal substance for preserving warmth and is the best material for coverlets, puffs, cushions, etc. Its money-value is considerable and there is always a demand for it in the markets of the world. ${ }^{1}$ The retail price in Boston at the present time ${ }^{2}$ of well-cleaned Iceland or Norwegian eider-down is $\$ \mathrm{I} 4$ a pound. It is probable that each nest fur-

1 The down obtained from dead eiders, however, soon loses its elasticity and is of little value.

2 I913. 


\section{IN AUDUBON'S LABRADOR}

nishes - as a very conservative estimate from an ounce to an ounce and a third of down, therefore twelve to sixteen nests or breeding females are needed for each pound. Burton states that the annual supply of down in Iceland rose from two thousand pounds in 1806 to seven thousand pounds in I870. One can easily understand the great value of this product even if the producer receives only one half of the retail price. He could count on at least fifty cents a season for each breeding female in his eider-fold.

Imagine the pleasure as well as profit that could be obtained along the coast of Labrador, Newfoundland, Nova Scotia, and Maine if these birds were treated in the manner above described and flocked and nested about the habitations of man. Then, each dweller in suitable localities by the sea could have his own flock of these beautiful birds - for the female is as beautiful in her modest dress of shaded and penciled brown as is the male in his striking raiment of jet-black and cream- and snowwhite, delicate sea-green and dark navy-blue. The cooing notes, so long few or absent in many places, would again resound over the waters, 


\section{CONSERVATION OF THE EIDER}

and, best of all, to the practical-minded, the birds would pay well for their protection by gifts of eggs and of valuable eider-down.

How can the present senseless habit of destruction be stopped and this desirable state of affairs brought about? As a preliminary step in Labrador and Newfoundland I would suggest that a few islands scattered along the coast should be made bird reservations, and carefully guarded by one or two families who live on or near the islands. These people should be allowed to take the first set of eggs and down, as well as the down left behind after the duck has hatched out the second set and has left for the season, but should not be allowed the use of firearms, and their Eskimo dogs must be confined during the nesting-season. In other words, these people must not frighten the birds and must treat them kindly. The object of the experiment should be spread broadcast along the coast with the request for fair play, so as to restrain others from poaching and frightening the ducks on the reservation.

The rapidity with which the birds will respond to this treatment and the intelligence they will display in the recognition of the safety 


\section{IN AUDUBON'S LABRADOR}

spots will surprise the people. This is the case wherever bird reservations are established. At Ipswich, Massachusetts, the shores of a small, protected pond are thronged with shore-birds of many species which display almost no fear of man, while on the neighboring beaches, where they are shot, they are very wary. In the city of Boston the Charles River Basin and Jamaica Pond are the resorts of numerous ducks that pay but little attention to the people, while in the sea and ponds near by, where shooting is allowed, the ducks show their usual wildness.

It is useless to pass laws if they are not observed or if the sentiment of the community is against them. This reform, which will be of such great value to our northern seacoast, can only be accomplished by education, and these bird reservations with their eider-farms will be one of the best means to that end. 
APPENDIX 



\section{APPENDIX}

For the opportunity to publish the following letters from George C. Shattuck, Jr., from his father, George C. Shattuck, from B. Lincoln, and from Audubon himself, I am indebted to Dr. Frederick C. Shattuck, the son of George C. Shattuck, Jr., who accompanied Audubon on his Labrador trip.

George C. Shattuck to George C. Shattuck, Jr., at Bowdoin College

My Son, -

Yours of the 2Ist inst. has just arrived. I am glad you have called on the Rev'd President and thank him for the courtesy he extended toward you. Tender him my respects when you may next see him.

Since my last I have received the Birds of America by J. J. Audubon (vol. Ist) and a splendid work it is too. $\$ 200$ for the vol. \& $\$ 20$ for half binding in Russia backs \& corners. His Turkies, Eagles, Owls, Hawks etc. etc. are magnificent! superb! transcendent!

M. Audubon has imparted to me an invitation for you to accompany him on the Labrador Coast the coming summer- of course I thanked him. He will be in Eastport the first of May. Your Lectures will not have been finished at that time. Dr. 


\section{APPENDIX}

Parkman ${ }^{1}$ has recently obtained for him two new subscribers. ... accept for your self the renewed expression of love from your

$$
\text { Father, }
$$

Boston, March 24, 1833.

G. C. Shattuck.

George C. Shattuck to George C. Shattuck, Jr., at Bowdoin College

My Son, -

Mr. Audubon called this evening and repeated the invitation for you to accompany him in his ornithological excursion, to the Coast of Labrador. I told him I should submit it to your option, that if you had an ardent desire to go, I should not repress it, and if you had no special desire to go, I would not urge it. If you desire to accompany him, you may raise funds by drawing on me at sight and selling the bill. Mr. Audubon says that two hundred dollars and coarse clothes are the necessary outfit. If you conclude to go, settle up at Brunswick all your accounts and start for Eastport. Audubon sails this evening for Eastport \& here he will remain about ten days. You may take Bangor in your way. If you have no strong desire to go on this expedition, you will regulate your course in Maine before your return as you may desire. Write me your wish by next mail.

Boston, May 4, 1833 .

Your father,

Geo. C. Shattuck.

${ }^{1}$ Dr. George Parkman who was murdered by Dr. Webster in 1849 . 


\section{APPENDIX}

Geopge C. Shattuck to George C. Shattuck, $J_{P}$, at Eastport, Maine

My Son, -

... I have also sent you letter paper said to be made of linen rags, both for your journal and for the letters you may have occasion to write. I beg you to make a daily record of what you may see, and to write to me as opportunity may offer. Let your journal be written in a legible hand writing. ... .

Possibly you may visit Mr. Lincoln's family at Dennisville. ...

Boston, May 8, 1833 .

\section{Extract from letter of George C. Shattuck, Jr., to his father}

EASTPORT, May 9, I833.

$\mathrm{He}$ [Mr. Audubon] insists much on a large journal in which he will make me write every night an account of the day's work, and then read it to him. I shall have to work like a horse as he says. He is going to charter a vessel for himself, which is to move entirely as he directs. He has written to a friend in Philadelphia to come on and join us, and Tom Lincoln will probably go too. The advantages will be very great, and I can not be too grateful to you for the permission and means to go. We will probably sail in about a fortnight, and will be absent two and a half or three months. In the mean time I shall be in training, under the direction of $\mathrm{Mr}$. Chadbourne, and I am rejoiced I came on. I have seen young Audubon also, and everything looks favorable for a season of interest and instruction. 


\section{APPENDIX}

B. Lincoln to George C. Shattuck, Jr., at Eastport

Burlington, Vт., I2th May, 1833.

... By all means go to Dennisville if you can perhaps my brother Tom may be invited to go too - he is an old crony of Mr. Audubon. Whether he could go or not I know not, but I should much like to have him go. - he would be a fine companion for you.... Would to God I could go with you. Will you not return by the way of Lake Champlain?

I do not know how your vegetable eating will do in a country where men eat Fish - "feathers and all." I think you will find your health improved by the cruise and you will to the day of your death rejoice that you went. ...

George C. Shattuck to George C. Shattuck, Jr., at Eastport

\section{My Son, -}

Yours of the 9 th inst has been received. A double barrelled gun with percussion locks, custom work, and Io lbs of powder and five thousand caps have been secured through the kindness of Mr. Hiram Smith and are forewarded by the Packet Boundary to Eastport. Mr. John Allen made the case for the gun, and insisted that you should have wads and ball and another pound of Mr. Ware's best powder, all of which you receive in the case with the gun. The ammunition otherwise is put in a candle box and directed to you, and with it the accompaniments of the gun. Enclosed is a letter from Baltimore via Brunswick. I have written to you twice at Eastport 


\section{APPENDIX}

and sent you the books and some clothing by the packet which sailed last Saturday.... To Mr. \& Mrs. Chadburne tender my compliments and sincere thanks for their kindness to my son.

To Mr. Audubon and to his son tender my best regards, and accept for yourself a father's blessing from

Geo. C. Shattuck.

Boston, May 17, 1833.

\section{George C. Shattuck, Jr., to his father}

EASTPORT, May 22, 1833 .

... This morning I have taken a long walk with Mr. Audubon, notwithstanding the rain.

Mr. A. has made all arrangements for his vessel. She is a schooner measures one hundred and six tons, and is said to be a very fine sailor. He pays three hundred and fifty dollars a month for her and each of us is to pay three dollars a week for board. We are to be victualled for five months, and among the articles to be put on board are potatoes; rice; beans; beef; pork; butter; cheese. We shall live like princes. You can not expect us before the first of October. Mr. A. says I must return to Boston with him via Quebec. ...

\section{George C. Shattuck, Jr., to his father}

EASTPORT, May 26, 1833 .

I must hasten to acknowledge the receipt of the two boxes which arrived here in the vessel on Thursday morning, but which on account of absence, I 


\section{APPENDIX}

did not receive till last evening. The gun is just the thing I wanted long and strong, the ammunition and accoutrements are all of the first quality, nor can I express too strongly my sense of obligation, at these renewed instances of your kindness and liberality.

I returned last evening from an excursion in the revenue cutter Swiftsure to the island of Grand Manan. This island is distant some twenty miles from here, is ten miles long, three or four broad, and belongs to his British majesty. We went on board the vessel, Wednesday evening and the anchor was weighed about three the next morning. We passed along the western shore of the island, where we saw steep precipices, sixty, a hundred, or even two hundred feet high, offering a very rough reception to any vessel driven upon it by a storm. We passed round the northern extremity of the long island and stopped in a small harbor of an island, two miles east of Grand Manan. We went on shore, and called at the house of the only inhabitant $\mathrm{Mr}$. Frankland, the governor of the island. We did not find this man at home but afterwards met him, when he expressed great pleasure at seeing us, and gave us permission to wander over his island, and to shoot as many birds, and take as many eggs, as we might wish and could find. Accordingly we proceeded over the island. We soon saw gulls enough to convince us that there were an immense number on the island, and at the same time that they were very shy. They flew over our heads in large flocks, but it was very rarely that any one descended so low, as to be within eighty yards, quite a long distance of 


\section{APPENDIX}

us. The island contains about two hundred acres, is very well wooded, and yields a large quantity of hay, and little else besides, except a few potatoes. The road which we pursued was extremely wet and muddy, but my long fishermans boots, made me at home there. Our party consisting of eight, killed twelve gulls, but found only one or two eggs. We were too early for these birds generally had not commenced laying, and if we had waited three weeks or a month, we should have found eggs in abundance, and the birds much less shy. We rambled about six hours or more, and then returning to the vessel, we enjoyed very much the food set before us. After dinner John and myself went to work to skin the birds and this task having been performed, principally however by John, for as yet I am not very expert at the business, we went on shore, it being eight o'clock, to enjoy the fresh air, and to meet Mr. A. who with the Captain of the cutter, went on shore after dinner, to ramble round, and to pay their respects to the governor. To the governor's house, accordingly, we' proceeded, and there we found our party, having taken tea, and passed the evening there. Mr. Frankland is an old man, a native of Yorkshire in England, whence he came to this island some fourty odd years ago. $\mathrm{He}$ retains the Yorkshire dialect, so that you would know whence he came talking with him five minutes. $\mathrm{He}$ is an intelligent, kind hearted old farmer, and I was desirous to see more of him than I had opportunity. He was very hospitable to us, and his two sons accompanied us on board our vessel, to serve as guides to two collections of islands, called the 


\section{APPENDIX}

two islands and the three islands which we were to visit the next day. Having written my journal I went to bed about half past ten, and so sound was my sleep, that I did not hear the grating of the chain when they weighed anchor, between eleven and twelve that night, and I was much surprised to learn the next morning, that we were lying in a different harbor. Having eaten an early breakfast, we pushed ashore in two parties, one to each group of islands. I accompanied Mr. Audubon to the three islands, which we explored very thoroughly, finding however scarcely any birds. Two of a species of ducks called lords and ladies were killed by one of our party, also a bird called a turnstone, and we saw one bird very rare, called about here the sea goose, which Mr. A. was very desirous to examine, but we did not succeed in killing him. Returning on board, we found that the other party had killed some eider ducks, and a few sea pigeons, but it was evident that the ducks mostly had gone north, to their breeding places. The same afternoon we returned back to our former station, returned to the governor his two sons, paid our parting respects, and continuing on from six to ten miles further, stopped for the night at long island harbor. We saw two or three houses along the shore, and a couple of fishing vessels. The next morning having taken an early breakfast we were rowed ashore, and John and myself, spent three or four hours rambling through the woods. We found some acres of cleared land around the houses, hills quite high, and some most delightful views. We could see from a cleared spot of land, gently rising from the sea shore, the houses below, 


\section{APPENDIX}

and the seashore, and then the bay coming in, and surrounded on three sides by the land. Another party took a boat and coasted along the rocks. They shot several sea pigeons, a most beautiful bird, a white spot on their wings, the rest of their plumage being black, or dark green changeable, and varying as seen in different lights. As we had a very fair breeze we accomplished our return very speedily, stopping to get some young ravens. The nest in which they were found was in the clefts of a very steep rock, and one of the sailors descended to it, by attaching a rope to a tree above and climbing down, being obliged to shoot in afterwards, as the rock over jutted considerably. The ravens were about three weeks old, and the ugliest birds without exception that I ever saw. Mr. A. thinks of taking one to Labrador, making a pet of it, and teaching it to talk. It was five o'clock when we landed at Eastport, having had a very pleasant time. The weather was as fine as we could have desired, and our accommodations on board the cutter were very good. The second lieutenant had been a warrant officer on board the Hamilton with Captain Derby. Mr. A. wished he had applied at Washington for this vessel, to go to Labrador, and the officers told us, they would have liked nothing better than such an excursion.

Our vessel has not arrived from Baltimore, but is expected every hour. She probably will come to day or to morrow, and we shall sail on Thursday, or Friday. Mr. A. is anxious to get off as soon as possible. I am ready, with the exception of a few articles, which I shall procure to morrow. I ex- 


\section{APPENDIX}

pect to walk to Dennysville to day, and to return to morrow.

If possible I shall send you a few lines just before I sail. Any letters that come had better be retained at home, for there can be no certainty that any communication would reach me. I received your last inclosing one from Brune on Wednesday. B. tells me his brother has gone to the western coast of South America, as supercargo to a vessel, where the cargo is worth seventy thousand dollars. What an undertaking for a young man only eighteen years of age. The vessel belongs to a merchant in Baltimore a friend of his fathers.

Do let me find a letter at Eastport on my return, giving an account of whatever has happened during my absence. It is not with indifference, I assure you that I contemplate, an absence of three months in which I probably shall not hear a word from home. But there is a God who orders all things for the best, and in whose hands we all are. Let me then again subscribe myself,

Your's dutifully and affectionately

G. C. S., JR.

\section{George C. Shattuck, Jr., to his father}

AMerican Harbor, Labrador, June 22, 1833.

As a vessel has just come into the harbor I will prepare a letter giving some account of myself since my last dates. Thursday June 6 . at twelve oclock our vessel was announced as ready, and our friends who had come on board to bid us farewell, and to look at our accommodations, informed that they 


\section{APPENDIX}

must step ashore. We cast loose and as we pushed off were saluted with four guns from the fort, and four from the revenue cutter. The wind was dead ahead but we beat down with the tide, and the Captain of the cutter accompanied us till we were steered clear of all difficulties, and were launched out into the bay of Fundy. We kept on and by night had beat down to Little river; a distance of twenty or thirty miles, but the wind dyirg away, we did not succeed in getting into the harbor. A breeze sprung up about noon the next day, which increased the next night, and Saturday afternoon we steered round Cape Sable between the mud and seal islands, rejoicing that we were clear of the bay of Fundy with its confounded tides. We passed by Halifax at a distance of thirty miles, and at night spoke the schooner Caledonia from Boston bound to the Labrador. Monday afternoon we made Canseau and as the wind was ahead for going through the gut, we run into the harbor, where we found several other vessels waiting contentedly for a fair wind. There are a few inhabitants at this place, who derive their support from the fishery, but the land is poor and yields only a few potatoes. We obtained however some milk and eggs, which savored very well, especially as we bad adieu to the latter when we pushed off from Eastport. The next morning at four oclock we set sail again with a fair wind, and crossing the bay were soon in the gut of Canseau through which we had a most delightful sail. This name is given to the passage between Cape Breton island and Nova Scotia, a narrow strait where you see distinctly both shores. The 


\section{APPENDIX}

N. Scotia shore is the highest but the Cape Breton shore appeared the greenest. Houses were scattered along the banks, and we saw something like a village at Ship harbor on the Cape Breton side. We stopped at Jestico island just as we were getting into the Gulf of St. Lawrence. We stopped also at the Magdalen islands, and spent a day rambling round. We stopped at Amherst island and found a hundred and fifty families there with a Catholic priest a Mounsieur Brulette from Quebec. These men support themselves by fishing and the soil yields a few potatoes. They are Canadian French, but the merchant who resides there, sells them their goods and buys their fish, is a native of Halifax, a shrewd fellow, who has made his fortune. A few wild geese breed in ponds but not on the part of the island where we were. They have foxes, hares, rats, no other wild animals. The next day we had a fair wind, passed the bird rocks, where we saw Gannets by thousands so thick, that the top of the rock looked as if covered with snow, but were unable to land on account of the surf. We passed Anticosti and arrived at this place last Monday, having had a very comfortable passage. We have been shooting away here but have not come to the parts where birds are most abundant. There are five vessels in the harbor from Eastport, fishing for cod, and they average about a thousand a man. Most American vessels go farther north, but we have one here from Newburyport, and one from Halifax Nova Scotia. The fishermen are up every morning at half past two work eighteen hours in the day, and sleep four. The fishing is done in boats off from the shore, 


\section{APPENDIX}

the fish are brought to the vessels, where they are opened by one man, their heads cut off and guts removed by another, whilst a third cuts out the back bones, and throws them into the hold, where two men are employed salting and packing them away. Afterwards they take the fish out and dry them. A Captain Billings from Eastport owns these five vessels and is here with them. He is going north, and expects in August to keep two vessels for the mackerel fishery. They throw out pieces of mackerel to toll the fish, put on bait to their hook which lasts all day, and throw the fish on the deck without touching hands to them. One man can catch fourty in a minute. The fishing on this coast is said to be better than off Newfoundland. The country is very rough sterile covered with moss and a few scraggy fir trees for forrests. You can not conceive more fatiguing walking than over this moss, and can be compared to wading through snowdrifts. Our excursions will be made mostly in boats. We start hence with the fair wind which first blows.

Our party are all in excellent health and spirits. I never enjoyed better health. We were sea sick some days, and wished ourselves any wheres, but we recovered and our appetite returned most wonderfully sharpened. I have been obliged to give up my experiment of a vegetable diet for the pilot bread when eaten exclusively makes me very costive, and whilst I was sea sick I lost my relish for potatoes. Since we have been in this harbor we have lived on codfish which are very nice and of which we all are very fond. 


\section{APPENDIX}

June 26.

The vessel by which I expected to have sent this letter proved to be his majesty's surveying schooner Gulnare, commanded by Captain Bayfield of the royal navy. They are taking a survey of this coast, and making charts, which when completed will be very thorough and accurate. They have already passed one summer in this employment, and expect to spend three or four more. A physician is on board who is a good deal of a botanist; conchologist; something of an ornithologist. Thus this coast has been much more explored than we thought for, and the field we expected to find unexplored has been pretty well beaten. Mr. A. has been invited to dine with Captain Bayfield, and actually ate roast mutton on the coast of Labrador. He ascertained from them that we are in Little Natashquam harbor, Latitude $50^{\circ} \mathbf{I} 2^{\prime}$, longitude $9^{\circ} 23$ east of Quebec; $6 \mathrm{I}^{\circ} 53^{\prime}$ east $^{1}$ of Greenwich. We are doing nothing waiting for a west wind these last five days, for we have explored the country very thoroughly, and find almost nothing of interest. Snow and ice are met with in sheltered spots every few steps, and as we run down the coast we saw a good deal.

July 23.

I resume my pen, to inform you of my continued health and happiness up to this date. We are now at the great Mecatina, whence we sail for Bon esperance by the first fair wind. We expect to find there several vessels from Boston, and in some of them

1 Error for west. 


\section{APPENDIX}

letters. We visited a port this morning where we found a vessel loading for Quebec, and where we were very glad to see Quebec papers, in which were Boston dates to the twenty fifth of June.

Remember me to my friends, and be assured that, my absence from home has not diminished my attachment to it. My story I must tell when I get there, and it now is impossible to tell when we shall leave this coast.

Your's most truly and affectionately

$$
\text { G. C. S., JR. }
$$

We are in latitude $50^{\circ} 43^{\prime}$ : in longitude $59^{\circ} \mathrm{r} 5$, and the mosquitoes so troublesome that $I$ can scarcely write.

Rec'd Montreal 25 Aug't I833 and forwarded by your obdt. serv't

H. Gates.

George C. Shattuck, Jr, to his father

Bradore, Latitude 5I, Monday, August 5, I833.

I send you a few lines by a vessel which sails tomorrow for Mount dessert, and would thus assure you that I am well, and in good condition. We arrived in this port Friday July 24, having been out one day and night from the port at which I addressed you a letter, which you probably have received. Our cruise is nearly terminated for with the first fair wind which may blow next week, we move homewards. On our way we stop at Newfoundland, 


\section{APPENDIX}

and at Pictou on Prince Edward's island, ${ }^{1}$ so that we shall reach Eastport sometime in the first week of September. How much I have improved by my opportunities, must be left to your judgement, when we meet, as I hope we shall, some six weeks hence. We have not found Labrador, the country that the fishermen would have us believe. I expected to have obtained many curious specimens in comparative anatomy, but we have seen no quadruped larger than a rat. We have found no new plants, though we have looked closely over all the ground. Birds are much less plenty than we had been taught to expect them. Mr. Audubon has obtained much valuable information, and we all are glad that we have seen this country, for no description can convey a just idea of it. Labrador was not made for white men, and it is to be wished that it had been left in the possession of those whom God placed there. We have travelled over the country very thoroughly, and can bid adieu to Labrador without regret. If I was to come here again, I should wish to spend here the winter and the spring, as the quadrupeds of the country, such as reindeer, bears, foxes, hares, are to be seen only in this season. In the summer they retire into the interior, no one knows where. We have heard one bear, but could not obtain a sight of him, though we sought his acquaintance eagerly. Mosquitoes, and gnats are in greater abundance than any thing else.

I have written to Dr. Mussey ${ }^{2}$ an account of what I have seen, but have not descended to particulars

1 Pictou is in Nova Scotia.

2 Dr. Reuben Dimond Mussey. 



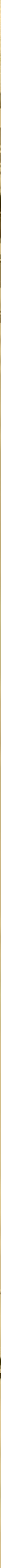






\section{APPENDIX}

here, as I expect to read you my journal ${ }^{1}$ when I return.

Remember me affectionately to all friends, and accept for yourself assurances of gratitude and affection from

Your Son,

$$
\text { G. C. S. JR. }
$$

\section{John J. Audubon to George C. Shattuck}

NEW YORE, $S e p^{r} 9^{h t}, 1836$.

My Dear Doctor Shattuck, -

I have great pleasure whilst I am informing you of my safe return to America, accompanied by my son John; and also in appraising you that I have brought over for you, a Ladies Watch handed to me at London by the Order of my Young Friend Your Son George. - Shall I keep this watch until I go to Boston in a few weeks, or shall I forward it to you by some one, willing as I am to deliver the same safely into your hands?

George was with us at London but a few days, he was quite well, and well doing at Paris, when I left England. Our Worthy Friend Doc ${ }^{r}$ Parkman had safely reached Havre, and I left my Wife and Victor quite well. - please to let me hear from you very soon, and believe me ever with the highest sentiments of respects \& esteem

\section{Your Friend \& Servant}

$$
\text { John J. Audubon. }
$$

1 Dr. F. C. Shattuck has no knowledge of this journal. 


\section{APPENDIX}

\section{John J. Audubon to George C. Shattuck}

NEw YoRk, July 5, 1837.

My Dear Friend, -

I write to you to inform you of my return here, and also to inform you that I will leave for Liverpool on the I6th Instant, accompanied by my Son John and his Wife, late Miss Bachman of Charleston. -

I have this day drawn a check on the Atlas Bank of Boston for the amount you deposited in that institution on my account in Jan. 7 last Favour of Nicholas Berthond Esq. or order. Say Six hundred and Fifty nine Dollars.

Now my Dear Friend will you have the goodness to write to me, and to inform me from whence the above amount was collected by you; so as to enable me to Balance, or at least to credit the proper parties in my books? -

My late Journey \& Voyage westward has prouved a very trying one to my body \& nerves - I have lost I5 pounds weight, and have not been as well as if under your care and roof - I however think that I am recruiting apace, and most sincerely Hope that I will see you and your Dear Family in about I 8 months; when I now calculate that my Work will have been finished, delivered and settled for in England. - Where is George and how is he? Where is our worthy friend Doc ${ }^{r}$ Parkman and family? I am quite in the Dark as regards the answers which I trust you will give me to these querries, and beg of you to transmit them, with an account of your Health \&c at your earliest Convenience.

My last dates from London are to the 20 of May, 336 


\section{APPENDIX}

when my beloved Wife and Son Victor were quite well. - My Publication was also going on quite well; but alas! The present commercial and monetary revolution has caused me to lose a good number of the Subscribers through whose Support, I did hope to realize a few Thousand Dollars to comfort and supply with the wants of our later days my Beloved Wife and my poor Self. Trusting however and for ever in that Providence, and in the care of him who supports us all, until called to his Bosom, I hope to see yet a less clouded Sky than the one hovering over our beloved Country at present, and be permitted to end our lives in peaceful enjoyment of health, and security of mind.

Offer my kindest, and most fervent wishes to your Dear Family towards their health and Happiness, Miss Lucy Included and believe me to be truly and for life your most truly thankful, grateful and sincere Friend and Servant

To George C. Shatruck, Esq., M.D.

$$
\text { John J. Audubon. }
$$

Boston.

Please to send word to my young friend Thomas M. Brewer M.D.? ${ }^{1}$ Winter Street, that I have written to him this day. Have you received one hundred Dollars from our Friend I. P. Davis ${ }^{2}$ on account of Daniel Webster? He was to pay that same on Jan. 7 last, on account of the latter's subscription to the Birds of America.

1 The ornithologist. He did not receive the degree of M.D. until 1838 .

${ }^{2}$ The historian and a friend of Daniel Webster to whom Webster dedicated the second volume of his works. 



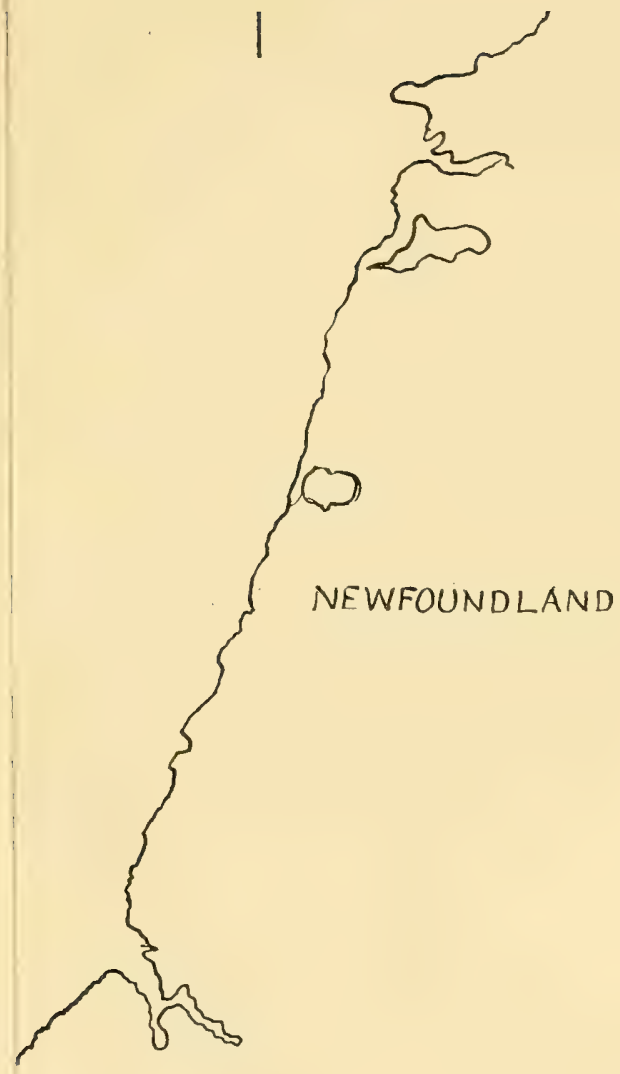




INDEX 



\section{INDEX}

Acadians, 12, 53, 81, 85, I39. Acunishuan, 55 .

Agriculture in Labrador, 27983.

Alder, Alnus incana, var. glauca and $A$. viridis var. mollis, I24, I 5I, I59.

Alexander. See Scotch lovage. Allen, Dr. Glover M., 40, 204, 302.

American Harbor, 8, 45, 72, 328.

Anse à Malouin, 2 ro.

Anse au Clair. See AnseÉclair. Anse des Dunes, 240, 262, 263. Anse Éclair, 256, 260.

Anticosti Island, 34, 190, 330. Audubon Island, I Io.

Audubon, John James, I, 7, 9, I0, I3, 22, $26,47,49,68$, $77,89,93,97,108$, I 20, I22, I30, I $36, I_{53}, I_{54}$, I57, I63, I66, I69, I74, $226,234,236,237,239$, $270,284,293$.

age, 15 .

birth, I6.

character, 3 .

fatigue, I5.

handicapped by ignorant pilot, I3, I7, 22, 77, I74.

homesickness, 17 .

hours of labor, 9, 14, 15.

interest in natural history, I8, 19. journal, $79,80$.

letters from, 335-37.

seasickness, I6, I53.

Audubon, John Woodhouse, $2,4,25$.

Audubon, Maria R., 3.

Audubon, Victor, 4, 335, 337.

Auk, Great, Plautus impennis, I90.

Razor-billed, Alca torda, 9, I3, 82, 89, 90, I I6, I 7 , I25, I29, I38, I39, I40, $172,223,240,243,290$, 294.

Baffin Land, 213.

Baie de Portage. See Mutton Bay.

Baie du Lac Salé, 172.

Bake-Apple. See Cloudberry.

Balsam fir, Abies balsamea, 65 , 69, 90, I 50, I 7 I, I75, 256, $257,263$.

Banding of birds, 98, 100.

Baneberry, red, Actea rubra, 252.

Bathing, sea, 76, I0I, I60, 196. Battle Harbor, 130.

origin of name of, 23I, 232.

Bay of Chaleurs, 4, 190.

Bay of Fundy, 5, 25.

Bay of Seven Islands, 30, 3I, 32.

Bay Johan Beetz. See Piashte Bay. 


\section{INDEX}

Bayfield, Capt., II, 20, 78, Bird Rocks, 6, 7, 330.

332 .
Beach pea, Lathyrus maritBird skins, 75, 128.

Birds, migrations, 30,107 ; $æ$ imus, 60, 184 .

Beaches, raised, 18,63 , $154-$ $56,200,211,223,250$, 260.

Beachgrass, Ammophila arenaria, 8I.

Bear, polar, Thalarctos maritimus, 168.

Bearberry, Arctostaphylos alpina, 262.

Beaver, Castor canadensis, 67.

Bec-scie. See Merganser, redbreasted.

Bedstraw, sweet-scented, $\mathrm{Ga}$ lium triflorum, 252.

Beetz, Johan, 36, 64, 97.

black fox industry of, 36,72 .

character, 37.

collection of birds, $4 \mathbf{I}$.

family, 37 .

garden, 39 .

practical jokes, 58, 59 .

table, 38, 39.

Bent, A. C., 36, 92, 108, 293, 303.

Beri-beri, I34, 277, 282.

Berthond, Nicholas, 336 .

Big Coxipi River, 197.

Birch, alpine, Betula glandulosa and var. rotundifolia, $65,123,262$.

white, Betula alba, 65, I42, I 75, 2 I I, 2 I 4.

Bird conservation, 283-3I6.

Bird destruction, I75, I82, 283-94.

Bird reservations, $\mathbf{1 7 2}$, 296$300,315,316$. thetic value of, 105, 106; dark plumage of Labrador, 202.

Bjarne, Herjulfsson, 212.

Blackbird, Red-winged, Agelanus phoniceus, $4 \mathrm{I}$.

Black grass, ${ }^{*} 6 \mathrm{I}$.

Blais, Capt., 264, 265.

Blanche, Monseigneur Gustave, 73 .

Blanc Sablon, 24, 109, 190, 244-7I.

forest trees of, 252-59.

geology of, 248-50.

origin of name, 249.

Blanc Sablon River, 249.

Blueberry, oval-leaved, Vaccinium ovalifolium, 226, 262.

Blue lumpfish, Cyclopterus lumpus, 267.

Bog, 8, 65, 68, 69, 87, 90, I23, I 24, I 84, 225, 280.

Bonne Espérance, 21, 226, 232.

Bossé, Monseigneur, 167.

Botanical specimens, 75, 93, I29.

Boucher, Capt., 66, 67.

Boulders, poised, 121, 122, I 58, I 59, 195, 200.

Bowl, the, 154,157 .

Bradore, 22, 24, I74, 234-38, 264.

* The black grass of the New England coast, Juncus Gerardi, has no representative in Labrador, although a number of plants there resemble it superficially. 


\section{INDEX}

Bradore Bay, 234-38.

Brant, Branta bernicla glaucogastra, 30 .

Bras d'Or. See Bradore.

Brest, Port of, 190, 223, 224.

Brewer, Thomas M., 337.

Brewster, William, I85, 303.

Bryant, Henry G., I8o, I8r.

Burroughs, John, 205.

Cabot, W. B., 204, 228.

Cambrian rocks, 36, r30, 248.

Campbell, Jere, 266.

Canadian Geological Survey, 27.

Canned rabbit, 39, 270.

Cape Cod, possible site of Vinland, $214,216,221$.

Cape Mecattina, I62, I63.

Cape Thiennot, I90.

Cape Whittle, I18, 121, I36, 291.

Capelin, Mallotus villosus, 39, I $83,270,273,274$.

Caribou, Cabot's barren ground, Rangifer articus caboti, 204 . woodland, Rangifer caribou, I 50, 204.

Cart-tracks, 263, 264.

Cartier, Jacques, 47, 189-92, $232,242,253$.

Cartwright, Capt. George, I $34,140,235,245,279$, $280,28 \mathrm{I}$.

Cascapedia, S.S., 27.

Cat-in-the-Wheel Inn, I2I.

Charts, II, 78, 79, I43.

Chateau Bay, 38, 107, 248.

Chevalier de St. Paul, 227.

Chevalier, Louis David, 227.
Chevalier, Louis Owen, 227, 228.

Chevalier's Settlement, 226, $227,228$.

Chickadee, Labrador, Penthestes hudsonicus nigricans, 202.

Chicoutai. See Cloudberry.

Chimney-Head Passage, 210.

Citronella ointment, 177 .

Clark City, 30.

Clintonia, Clintonia borealis, 252.

Cloudberry, Rubus Chamamorus, I2, 69, I83.

Coacoacho Bay, III.

Cod, Gadus callarias, 84, I32, 265-68.

Cod-fishing, 84, I3I, I 32, I33, I68, 265-68.

Cod-liver oil, manufacture of, $246,247,272,273$.

Cods' tongues, 272.

Cod-traps, I3I, I32, 208, 265, 266.

Comeau, Napoleon A., 28, 63. Compass, variation of, 159 . Conservation in Labrador, I34, 274-316.

Cook-room, 245.

Coolidge, Joseph A., 2, 3, 4,7 .

Coöperative stores, 146.

Cormorant, Common, Phalacrocorax carbo, II9.

Double-crested, Phalacrocorax auritus, I3, I0I-c6, I I I-I 4, I I9-2I.

Cormorants, as food, 102.

destruction of, IO3.

food of, 103, I04. 


\section{INDEX}

Cornel, dwarf, Cornus canadensis, 252.

Cornel, Northern dwarf, Cornus suecica, 12.

Corner, Dr. George W., 209.

Corte Real, 232.

Côte Nord, 35.

Cotton-grass, Eriophorum Chamissonis, E. callitris, E. angustifolium, and others, 65,69 .

Courtemarche, Legardeur de, 224.

Courtship of Black Guillemot, I40, I4I.

Cow-parsnip, Heracleum lanatum, 246.

Cranberry, mountain, Vaccinium Vitis-Idaa var. minus, 53, 54, 65, 183, I84, 2 I I, 2 I 7-2 I, 262.

Creighton, J. G. Alwyn, I79.

Crêpes, 77.

Cross Harbor, I54.

Cross, the, on Matchiatik Island, 127, I28.

Crowberry. See Curlew-berry.

Cumberland Harbor, I 88, I89.

Curlew, Eskimo, Numenius borealis, $23,107$.

Hudsonian, Numenius hudsonicus, 107.

Curlew-berry, Empetrum nigrum, 23, 65, I55, 21 I, 218,23 I, 262, 270.

Currant, Ribes triste and $R$. prostratum, 279.

Daly, Prof. Reginald, I59, I85, 204.

Darby River, I38.
Davis, I. P., 337.

Dawson, Dr. Samuel E., 224.

Deane, Ruthven, 3, 4, I8.

Dikes, 205, 206.

Dog-fish, Squalus acanthias, $267,274$.

Dog-food, I03, 222.

Dog-sledging, 78, 133, 174 .

Dogs, Eskimo, 54, 133 , I4750, 152, 168, I69, 222.

chorus, 152.

nature, 147-49.

objections to, I49, I50.

origin, 54 .

value, I33, I49.

Duck, Black, Anas rubripes tristis, 43, 44, I84, 185 .

Eider. See Eider.

Golden-eye, Clangula clangula americana, 88, 177, 178 .

Harlequin, Histrionicus histrionicus, 326.

Labrador, Camptorhynchus labradorius, 22.

Lesser Scaup, Marila affinis, $4 \mathrm{I}$.

Lords and ladies. See Duck, Harlequin.

Pied. See Duck, Labrador.

Duke's Island, $\mathbf{I} 88$.

Eastport, I, 5, 25.

Eel-grass, Zostera marina, 30.

Eggers, IO, IOI, I 82, 283-93.

Eggs, destruction of incubated, $285,290$.

Eider, Somateria dresseri, 9, $44,45,60,89,96,97$, r 39 , I75, I82, 289, 30I-I6. 


\section{INDEX}

conservation of, $30 \mathrm{r}-16$.

destruction of, 289, 290, 302-04.

down of, 44, 305-I5.

local names of, 301 .

European, S. mollissima, 305.

Northern, S. mollissima borealis, 302.

Elder, Capt. Sam, 266.

Elevation of coast, $6 \mathrm{I}-64$, 88, I2 I, I 54, I83, 249, 250.

Ellis Bay, 34.

Emerton, J. H., 69, I83.

Emery, Capt., I, 4.

English Point, 8o.

Ernest, cook, 77, 135, I83.

Eskimos, 2 I5.

former distribution of, 23I, 232.

numbers of, 33 .

Esquimaux Island, 230, 231.

Point, 35, 36, 231.

River, 227-29.

Eudist Brotherhood, 73, 26r.

Eye of the buck, I8I.

Ferland, Abbé, I69.

Fernald, Prof. M. L., 2 I I, 2 I3,

Fiards, 205.

Fiords, 204, 205.

Fir, Balsam. See Balsam Fir.

Fish, business, 244-47, 330, 331 .

fertilizer, 274, 275, 276, 28I . licenses, 295.

Fishing-room, 245.

Fishing season, 132.

Flatey Book, 212.
Flies, I6, 20, 47, 70, 86, I77. I95, 269.

Flounder, 274.

Flour, white, 28I, 282.

Fly, black, Simulium, 47, 269.

Flycatcher, Yellow-bellied, Empidonax flaviventris, 42, 50, 5I, I58.

Olive-sided, Nuttallornis borealis, 42 .

Fog, 238, 239, 260, 270.

Forest trees at Blanc Sablon, 252-59.

dimensions of, $252,257,258$.

Forest vegetation, 252, 254 , $255,256$.

Forbes, J. D., 204.

Forman, Jim, $8 \mathrm{r}$.

Fort Pontchartrain, 224.

Forteau, 24, 245.

Fox, black, Vulpes fulvus, 36, I33, 208, 277. red, Vulpes fulvus, 277.

Fox Island, I44.

Frankland, Mr., 324, 325.

Frazar, M. Abbott, 108, 136, 286, 304.

Fur-bearing animals raised in captivity, 36, 277-79.

Furs, 2 I, 57, 102, I66, I 79, 197.

Gagnon, Abbé, I6r.

Galibois Islands, I3I.

Galibois, Jean-Baptiste, 127.

Galibois, Joe, I3I, I38.

Gallichon brothers, I72.

Gallix, Père, 70.

Game-wardens, 294.

Gannet, Sula bassana, 6, 234, 330.

Ganong, Prof. W. F., r89. 


\section{INDEX}

Garden of M. Beetz, 39 . of Capt. Cartwright, 280, $28 \mathrm{I}$.

of Mr. Morrell, 247.

of Natashquan priests, $7 \mathrm{I}$.

of Donald Alexander Smith, 282.

Garnier, Père, 70.

Gasoline engine. See Motorboats.

Gilbert, Sir Humphrey, 238.

Gill-netting, 266, 267.

Glacial boulders, I2 I, 122, I58, I59, 195, 200.

cirque, 172 .

lunoid furrows, I85, 186. scratches, 159.

Godbout, 28, 32.

Godde. See Auk, Razor-billed.

Godefroy, Jean, 227.

Godefroy de St. Paul, Jean Amador, 227.

Godwin, Pilot, 6, 7 .

Goose, Canada, Branta canadensis, 30, 330.

Gosling, W. C., 23I, 232.

Grain rouge. See Mountain Cranberry.

Grand Bay, 45.

Grand Manan, 324.

Grand Romaine River, 83.

Granitic rocks, 99, I I0, I30, I $85,230,248,249$.

Grant, Edwin G., 244.

Grape, Northern fox, Vitis labrusca, 214-22.

Grape-vines, 216, 219.

Grassy Island, 2 I I.

Great Island, $\mathbf{7} 76$.

Great Mecattina Island, 167, I 72 .
Greenland, 2I2, 2 I6.

Greenly Island, 245, 265.

Gregory, G. W., 205.

Grenfell, Dr. W. T., I44-47, $210,226$.

coöperative stores, 146 . hospitals, I43, I44, I46. industrial stations, $\mathbf{I} 45$. mission, I45, 146. mission fleet, I46, I47. work of, 147 .

Grenfell Shoals, 188 .

Grouse, Ruffed, Bonasa umbellus togata, 190.

Spruce, Canachites canadensis, 19, 225, 226.

Guano, I I I, 282, 283.

Guillaume, mate, $76,77,135$.

Guillemot, Foolish. See Murre.

Guillemot, Black, Cepphus grylle, 125, I29, I $39, \mathrm{I} 40$, I $4 \mathrm{I}, \mathrm{I} 72,182, \mathrm{I} 88,2 \mathrm{I}$, 294.

Gulf of St. Lawrence, I7, 31, I53.

Gull, European mew, Larus canus, 136.

Great black-backed, Larus marinus, 44, 65, 82, 93 , 94, 96-IOO, I I I, I72, I75, 21 I, 291.

Herring, Larus argentatus, $44,82,2$ II.

Kumlien's, Larus Kumlieni, $4 \mathrm{I}$.

Ring-billed, Larus delawarensis, I35-37, 289.

Gull Cliff Island, I 44 .

Gull Island, I I9, I36.

Gulls, destruction of, 290, $29 \mathrm{I}$.

Gulnare, schooner, I I, 20, 332. 


\section{INDEX}

Gyrfalcon, Black or Labrador, Falco rusticolus obsoletus, 24.

Ha Ha Bay, I72.

Halifax eggers, ro, 286.

Hamilton Inlet, 197. River, I8o, I8r.

Harbor of Canso, 5 .

Hare, Dr. H. Mather, 29, 143.

Hare Harbor, I8, 154 .

Harrington, I43, I 44 . hospital, I43, I 44 .

Hawk, Pigeon, Falco columbarius, 88,89 .

Head of the Whale Islands, I60, I6I, I62.

Hearn, Capt. J., 27, 28, 29.

Helluland, 213, 216, 220.

Herrick, Francis Hobart, I5.

Hesry, Père, I6I, I 80, 240, 26 I.

Hill, James J., 35 .

Hind, Henry Yule, 55.

Horse, the Natashquan priests', 71, 72 .

Hospitals, Grenfell, I43, I44, I 46.

Houses, summer, 222; winter, I33, 222.

Hovgaard, Prof. William, 212, 216, 219.

Huard, Abbé, 81, 160, 161, I64, 235, 244.

Hudson's Bay Company, 10, $33,46,70,83,89$, I76, I 78 .

Hunt, Edward, 270.

Hveiti, 2I3.

Ice, 87 .

Iceberg, 22.

Iceland, 2 I 4, 305-13.
Île au Bois, 245, 255, 267.

Île Bayfield. See Sandy Isle.

Île de la Providence, I60.

Îles Affligées, 172.

Indians, Io, $47,53,54-57,83-$

85 , 101, $167,168,182$,

I96, 228, 23I, 302-04.

appearance, 56,84 .

camping-place, $54,83,84,198$.

dogs, $54,55,83$.

dress, 55,56 .

migration-routes, 57,178 ,

179.

numbers of, 33 .

photographing, 83,84 .

portage paths, $4 \mathrm{I}, 44, \mathrm{I} 63$,

I78, 181, I94, I96-20I.

race, 55 .

religious rites, $\mathbf{5 7}, 82$.

sweat-house, 199, 200.

Ingalls, William, 2, 3, 18.

International Grenfell Association, 145 .

Iris, blue, Iris versicolor and Iris setosa, var. canadensis, $6 \mathbf{I}$.

Island of Birds, 242.

Isles of the Blest, 220.

Jack Nasty Passage, 232.

Jacques Cartier's Harbor, 189 , 190-92.

Jay, Labrador, Perisoreus canadensis nigricapillus, 200, 203.

Jestico Island, 5.

Jigging for cod, $267,268$.

Job Brothers and Company, Limited, I 88, 244.

Joncas, Capt. A. Edmond, 36, 77-80, 108, I36, 163 . 


\section{INDEX}

Joncas, Richard, 46.

Jones, Mr., of Bradore, 22, $236,237,263$.

Jones, Gilbert, II 8.

Jones's Point, 237.

Juliet Harbor, I4I, I42.

Kakas, William, 33 .

Kegashka, 8I.

Kekarpoui Islands, I72.

Kenty Island, I6I.

King George the Fifth Seamen's Institute, $\mathbf{1} 45$.

Kinglet, Ruby-crowned, Regulus calendula, I58.

Kittiwake, Rissa tridactyla, 234.

Komatik, 78, I33.

Krækiber, 218.

Labrador, The, 32.

Labrador, Canadian, 32, 247, 292.

Labrador, Newfoundland, 32, 247, 292, 293.

Labrador Fur Company, 46.

Labrador Peninsula, area of, $3 \mathrm{I}$.

definition of, 3I, 32 .

population of, 33 .

Labrador tea, Ledum grcenlandicum, 43, 60, 69, 155 .

Labradorians, hospitality of, I 33,244 .

Lake Island, I2 I.

Lake Misstassini, 259.

Lalo, Ambroise, 100.

Larch, Larix laricina, 69, 90.

Lark, Horned, Otocoris alpestris, I4, 2I, 22, 9I, 92, I29, 195.
Prairie horned, Otocoris alpestris praticola, 92.

Shore. See Lark, Horned.

Laurel, pale, Kalmia polifolia, $12,65,69,88$.

Laurentian, S.S., 66.

Laurentian Mountains, 65, 81, 87.

Laws, game, 294, 295.

Leatherleaf, Chamcedaphne calyculata, 69 .

Leif, the son of Eric, $2 \mathrm{Ir}-\mathbf{I} 3$.

Licenses, fish and game, 295.

Lichens, 65, I42, I50, I55, I58, 2II, 230.

Limestone, Cambro-Silurian, 36, I30, 248.

Lincoln, B., letter from, 322.

Lincoln, Thomas, 2, I2, I6, $48,50,32 \mathrm{~T}$.

Linnæa, Linncea borealis var. americana, 252.

Little, Dr. John Mason, Jr., $\mathrm{I} 45,28 \mathrm{I}$.

Little Coxipi River, I93, I96.

Little Mecattina Island, I8, 20, I5I, I53.

Little Natashquan River, 8, 9, $45,47,6 \mathrm{r}, 70$.

Little Shecatica River, I93, I94.

Liveyeres, 302.

Lobster, Homarus americanus, 276.

Lobster Bay, 2 Io.

Lolo, Pierre, 84.

Long Point of Blanc Sablon, $240,244,261$.

Loon, Gavia immer, 203.

Red-throated, Gavia stellata, I5, 123,124 . 


\section{INDEX}

Lovage, Scotch, Ligusticum scoticum, 246.

Lungwort, Mertensia maritima, 57 .

Lydia Harbor, 2 I0.

McDuff, Dr., 29.

McKinnon, Jacques, 172 , I73.

Magdalen Islands, 5, 81, 190, 330.

Marconi Wireless Station, 38, I 44 .

Markland, 213, 216, 220.

Marmette. See Murre.

Maryland Yellow - throat, Geothlypis trichas, 90.

Masur, 213.

Matchiatik Island, I25, 127.

Mecattina Harbor, 20, I66.

Meigle, S.S., 270.

Menier, Gaston, 34 .

Menier, Henri, 34.

Merganser, Red - breasted, Mergus serrator, 43, 206, 207.

Michaux, Pierre Jean-Baptiste, 2I, I66.

Michel, Leander, 167.

Migrations of water-birds, 30 , 107.

Mineral wealth of Labrador, 283.

Mink, Putorius vison, 278.

Mission of St. Anne, I60, I6I.

Misstassini Island, I2I.

Misstassini Lake, 259.

Molony, M., 83.

Montreal, 27.

Morrell, Thomas, 247.
Mosquitoes, 16, 20, 47, 76, I Io, 280, 333, 334 .

Motor-boats, I88, 208, $21 \mathrm{I}$, 238, 292.

Mount Cartier, 238.

Mount St. John, 35 .

Mountain Cranberry, Vaccinium Vitis-Idea var. minus, 53, 54, 65, 183, I84, 2 I I, 2I 7-2I, 262.

Murre, Uria troille, 9, 13, 89, I I I, I I4-I 6, I 39, 284, 290. Brünnich's, Uria lomvia, II 7.

Ringed, Uria ringvia (= U. troille), II5, II6.

Murres, destruction of, 284$86,290$.

Muskrat, Labrador, Fiber zibethicus aquilonius, 278.

Musquarro, 82.

Mussey, Dr. Reuben Dimond, 334.

Mutton Bay, 20, 163, 164 .

Nadeau Island, 162.

Nansen, Fridtjof, 212, 218, 280.

Napetepi Bay, 2 Io.

Napetepi Lake, 2 Io.

Natashquan, history of, 72 .

Natashquan, steamer, $66,67$.

Natashquan Harbor, 8, 63, 64,332 .

Natashquan River, 10, 42, 46, $54,63,80,179$.

Natashquan Village, 45, 46, 66,72 .

Netagamon River, I42.

Newfoundland, 25, 209, 210 , 216. 


\section{INDEX}

Newfoundland, Bishop of, 95. Pitcher-plant, Sarracenia pur-

Newfoundland fishermen, I2I, I37, I56, 234, 235, 289, $293,295$.

Norsemen, 212-22.

North-West River, 178, I79, 282.

Notre Dame de Lourdes, 26I.

Oakes, William, 23.

Observation, lack of, 60.

Old Fort, 222-26.

Old Fort Island, 222.

Old Post, 168, I72.

Olson, Julius E., 2 II.

Open seasons for game, 295.

Outard. See Goose, Canada.

Outer Island, II I.

Packard, Prof. A. S., 238.

Parkman, Dr. George, 320, $335,336$.

Partridge-berry. See Mountain Cranberry.

Pashashiboo, 45.

Paul Nadeau Island, I83.

Perroquet. See Puffin.

Perroquet Island, 23, 23943.

Perroquet Islands, 8r, 288.

Petrel, Wilson's, Oceanites oceanicus, 234.

Pewee, wood, Myiochanes virens, $5 \mathrm{I}$.

Phalarope, Northern, Lobipes lobatus, 326.

Piashte Bay, 36, 4I, 44, 52 .

Pinguicula, Pinguicula vulgaris, I29, I30, I35.

Pipit, Anthus rubescens, I29, I $30,158,195$. purea, 69.

Plover, Killdeer, Oxyechus vociferus, 4I.

Pointe au Maurier. See SealNet Point.

Pointe des Monts, 32.

Pork cake, 269.

Porpoise, Phocena phocœna, 106, 107, 233.

Port of Brest. See Brest, Port of.

Portage, Grand, 196-20I.

Porter, Russell W., I80.

Potatoes, $7 \mathrm{I}$.

Poulailler, 136.

Poverty, I34.

Ptarmigan, Willow, Lagopus lagopus, I 5, 237.

Puffin, Fratercula arctica, I3, $24,89,234,239-43,288$, 289.

destruction of, 242, 288, 289.

nesting-burrows of, 24I, 289.

Pyrola, One-flowered, Moneses uniflora, 252.

Quatachoo, 45 .

Quebec, 28.

Quintal, I32.

Rail, Virginia, Rallus virginianus, I04.

Rapide Lessard, I74.

Raven, Corvus corax principalis, I 57, 175, 264, 327.

Redpoll, Acanthis linaria, 26I.

Redstart, Setophaga ruticilla, 42,43 .

Reeves, A. M., 2 II. 


\section{INDEX}

Reindeer, Rangifer tarandus, I 49, I 50 .

Reindeer moss (lichen), 65, 69, I 75, I83, 225.

Reservations, bird, 172, 296300, 3I5, 3I6.

Rigaud, Philippe de, 227.

Rigolet, La Grande, I 83 .

Rigolet, La Petite, I74-76.

Ripley, schooner, I, 4, I3, I8, $23,74,122,163$.

River as a guide, $\mathbf{r} 95$.

Robertson, Samuel, 21, 223, 224.

Robertson, Samuel, 3d, I68-7I.

Robin, Planesticus migratorius, 9, 184 .

Robin, George, 203.

Robin, Louis, 189, 203.

Rocky Bay, 2 Io.

Romaine, 83 . derivation of name, 83 .

Romaine, Old, I3, 89, 96, 140.

Romaine River, 83, 86, 87, 179 .

Ross, Sir Charles, 86.

Sable Island, 27.

Saga of Eric the Red, 2 I2.

St. Anthony, coöperative store, I46.

guest-house, I 45.

hospital, I 45 .

industrial house, I45.

mission school, I45.

orphanage, $\mathbf{I} 45$.

St. Augustine Hudson's Bay Post, 176.

St. Augustine River, I78, I79$8 \mathrm{I}$.

St. James River, I89, I9I, I92. St. John, Harold, botanist, 27,
$75,86,92,93,124,129$, I $35,163,177,197,201$.

St. John River, 35 .

Saint-Malo, 190.

St. Mary's Island, 80, I3I.

St. Paul River, 21, 197, 227. 229.

St. Paul's Bay, 228.

Salmon, Salmo salar, 35,85 , I03, 104.

Salmon Bay, 232.

Salmon fishing, 4I, 45, I03, I04, I33, I40, I 75, 228, 229.

Salt-marshes, 6r, 62.

Sand-banks, marine, $63, \mathrm{I} 84$.

Sand dunes, 81, 260, 262, 263.

Sandpiper, Least, Pisobia minutilla, 124, 125.

Spotted, Actitis macularia, I08, 109.

Sand-ridges, 88.

Sandstone, 240, 248-50.

Sandy Island, I82, I 84.

Scoter, White-winged, Oidemia deglandi, 8.

Scurvy, 134, 277, 280.

Seal, gray, Halichorus grypus, I38.

Harbor, Phoca vitulina, 38, I33, I38.

Harp, Phoca grcenlandica, $133,138$.

Sealing, 276,277 .

Seal-meat, 38, 39, 183, 277.

Seal-netting, I38, I68.

Seal-Net Point, I3I, I35, 289.

Sea goose. See Phalarope, Northern.

Sea-pigeon. See Guillemot, Black. 


\section{INDEX}

Sea Star, schooner, $36,45,74$, 75, I3I, I35, I62, I73, I95. Sedge, Dewey's, Carex deweyana, 252.

Seebohm, Henry, 202.

Seven Islands, 33, I79.

Shag Island, 144.

Shaler, Prof. N. S., 260.

Shattuck, Dr. F. C., 3 I9.

Shattuck, George C., Sr., letter from, 319-23.

Shattuck, George C., I, 4. letters from, 323-35.

Shecatica Bay, 188, I89.

Shecatica Inlet, I89, I92, I93, 204.

Shecatica Island, 208.

Sheldrake. See Merganser.

Shooting, spring, 288.

Silver-weed,Potentilla pacifica, $6 \mathrm{I}$.

Skraelings, 215.

Sleeping-bag, 75, 76.

Smith, Donald Alexander. See Strathcona, Lord.

Snipe, Gallinago delicata, 260.

Snow, I5I, I63, 165 .

Snowberry, Chiogenes hispidula, 226, 252.

Soil formation, 65 , 156 .

Solomon-seal, dwarf, Maianthemum canadense, 252.

Sparrow, Fox, Passerella iliaca, 9, 21, 47, 184, 202.

Lincoln's, Melospiza lincolni, I I, I 2, 2I, 26, 48-50, 260.

Song, Melospiza melodia, $48,259,260$.

Swamp, Melospizageorgiana, 260.
Tree, Spizella monticola, 9I.

White-crowned, Zonotrichia leucophrys, 21, 39, 175, I 84,195 .

White-throated, Zonotrichia albicollis, 30, 47, 184 .

Sparr Point, 21, I68.

Species, value of, 104-06.

Sphagnum, 69, 88.

Spiders, 69, 70, 183 .

Spitting habit, 209, 2 I0.

Splitting-table, 85, 132.

Spring, Arctic, 9, 10, 165.

Spruce, black, Picea mariana, $65,68,69,70,81,87,90$, I55, I75, I93, 257, 258, 263.

white, Picea canadensis, 66.

"Squatters of Labrador, The," $21,166,236$.

Star-flower, Trientalis americana, 252.

Storms, 8, I4, I7, 93-95.

Straits of Belle Isle, 3I, 244, 255.

Strand wheat, Elymus arenarius, I42, I83, 2II , 2I4, $262,28 \mathrm{I}$.

Strathcona, Lord, I78, 275, 282.

Strathcona, S.S., I46, I 88, 226.

Stumps at Blanc Sablon, 25259.

Subsidence of coast, 61, 62, I2I, 158 .

Sundew, Drosera rotundifolia, I29.

Sunrise, I53.

Sunset, 186, 187 .

Swallow, Eave, Petrochelidon lunifrons, $4 \mathbf{I}$. 


\section{INDEX}

Sweet-gale, Myrica Gale, 69. Swiftsure, Cutter, 324 .

Syrinx, 87 .

Tabatière Bay, x67, 168.

Taverner, P. A., I03, I04.

Telegraph line, $\mathbf{1} 32$.

Temperature, $20,25,53,68$, I5I, I7I.

Tern, Caspian, Sterna caspia, I07, 108.

Common, Sterna hirundo, 44, 108.

Royal, Sterna maxima, 108.

Théberge, Abbé, I60.

Thrills in the pursuit of hobbies, 201, 202.

Thrush, Hermit, Hylocichla guttata pallasi, 30 .

Tickle, 230.

Tinker. See Auk, Razorbilled.

Tishkatawaka, 63 .

Toads, trilling of, 64 .

Tommie, steam trawler, 266.

Trees, age of, 259.

Tremblay, Dr., 29.

Trinity, 28.

Triple Island, 82.

Trout, Salvelinus, I77, 203.

Trout fishing, 268, 269.

Trout River, 33.

Tuberculosis, 209, 210.

Tundra. See Bog.

Turnip-tops, 39 .

Turnstone, Ruddy, Arenaria interpres morinella, 326.

Tyrker Southman, 213, 218, 22 I.

Ungava, 31 .
Vatergamashook, 199.

Vie toujours. See Lungwort.

Vignot, Alfred, 72.

Vignot, Charles, 72, I64.

Vignot, Paul, 72.

Vikings, 214 .

Vinber, 213, 216-22.

Vinland, $211-22$.

Vinvio, 213, 219.

Violet, great-spurred, Viola Selkirkii, 252.

Voyage, 245 .

Wakefield, Dr. Arthur, 2 Iо.

Walrus, Odobenus rosmarus, 203.

Wapitagun, 90, I2I.

derivation of name, I2I.

Wapitagun Harbor, 13, I22, 123.

War news, 35, 38, 58, 164 .

Warbler, Black and White, Mniotilta varia, 42.

Black-poll, Dendroica Striata, 42, 43, 157, 175 .

Black-throated green, Dendroica virens, 42, 43.

Magnolia, Dendroica magnolia, 42.

Tennessee, Vermivora peregrina, 30, 42, 5I, 52.

Yellow, Dendroica cestiva, 42.

Yellow palm, Dendroica palmarum hypochrysea,42.

Wilson's, Wilsonia pusilla, $21,86,87$.

Washsheecootai, 82, II3.

Watcheeshoo, 45, 59.

Waterfalls, 9, 4I, 44, 45, 64, $65,142,194,195$.

Water-power in Labrador,283. 


\section{INDEX}

Water thrush, Seiurus nove- Winter, pleasures of, I33, 134. boracensis, 42, 194.

Webster, Daniel, 337.

Wizard, schooner, 22.

Wolf Bay, II7.

West, Dr. J. H., 29, I43.

Whabby. See Loon, Redthroated.

Whale, sub-fossil, 64 .

Whale factory, 30 .

Wheat, 220.

Whistling for a breeze, 143 .

Widgeon, European, Mareca penelope, 4I.

Wilcomb, Capt., 22.

Willson, Beckles, 178.

Windlasses for seal-nets, I38.

Wine-making of the Norsemen, 217-22.

Wood, Col. William, 298.

Wood-piles, 222.

Wood-pulp, 30, 283.

Wren, Winter, Nannus hiemalis, 21, I24.

Yankee Harbor, 13I.

Yellow-throat, Maryland, Geothlypis trichas, 90.

Zone, Arctic, 4I, 90, 9I, I30, $158,193$.

Hudsonian, 4I, 9I, I58, 193. 



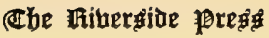

CAMBRIDGE - MASSACHUSETTS

$\mathbf{U} \cdot \mathbf{S} \cdot \mathbf{A}$ 



Sackman Bindary.

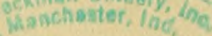

\section{APR 1959}





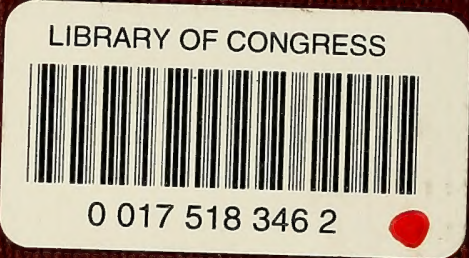

